\title{
Dw2, a New Dwarfing Locus in Apple Rootstocks and Its Relationship to Induction of Early Bearing in Apple Scions
}

\author{
Gennaro Fazio ${ }^{1}$ \\ Plant Genetics Resources Unit, USDA-ARS, 630 W. North Street, Geneva, NY 14456 \\ Yizhen Wan \\ Apple Research Center, College of Horticulture, Northwest A\&F University, Yangling, Shaanxi \\ 712100, China \\ Dariusz Kviklys \\ Lithuanian Institute of Horticulture, Babtai, Lithuania \\ Leticia Romero \\ Facultad de Ciencias Agrotecnológicas, Ciudad Universitaria s/n Campus 1 C.P. 31310 A.P. 24 \\ Chihuahua, Mexico \\ Richard Adams \\ Willow Drive Nursery, 3539 RD 5 NW, Ephrata, WA 98823 \\ David Strickland \\ Department of Molecular \& Cellular Biology, Dartmouth University, Hanover, NH 03755 \\ Terence Robinson \\ Department of Horticulture, NYSAES, Cornell University, Geneva, NY 14456
}

\begin{abstract}
AdDitional INDEX words. gene interaction, precocity, single-nucleotide polymorphism, SNP, tree architecture, QTL mapping, yield efficiency

ABstract. The ability of certain apple rootstocks to dwarf their scions has been known for centuries and their use revolutionized apple (Malus $\times$ domestica) production systems. In this investigation, several apple rootstock breeding populations, planted in multiple replicated field and pot experiments, were used to ascertain the degree of dwarfing when grafted with multiple scions. A previous genetic map of a breeding population derived from parents ' $O$ ttawa 3' $(0.3)$ and 'Robusta 5' (R5) was used for quantitative trait locus (QTL) analysis of traits related to scion vigor suppression, induction of early bearing, and other tree size measurements on own-rooted and grafted trees. The analysis confirmed a previously reported QTL that imparts vigor control $[D w 1$, $\log$ of odds (LOD) $=7.2]$ on linkage group (LG) 5 and a new QTL named $D w 2(L O D=6.4)$ on LG11 that has a similar effect on vigor. The data from this population were used to study the interaction of these two loci. To validate these findings, a new genetic map comprised of 1841 single-nucleotide polymorphisms was constructed from a cross of the dwarfing, precocious rootstocks 'Geneva 935' (G.935) and 'Budagovsky 9' (B.9), resulting in the confirmation and modeling of the effect of $D w 1$ and $D w 2$ on vigor control of apple scions. Flower density and fruit yield data allowed the identification of genetic factors $E b 1(\mathrm{LOD}=7.1)$ and $E b 2$ (LOD $=$ 7.6) that cause early bearing of scions, roughly colocated with the dwarfing factors. The major QTL for mean number of fruit produced per tree colocated with $D w 2(L O D=7.0)$ and a minor QTL was located on LG16 $(L O D=3.5)$. These findings will aid the development of a marker-assisted breeding strategy, and the discovery of additional sources for dwarfing and predictive modeling of new apple rootstocks in the Geneva ${ }^{\circledR}$ apple rootstock breeding program.
\end{abstract}

Grafting scions from trees with desirable fruit onto different tree root systems is an ancient technique and perhaps one of the first forms of clonal propagation. Most temperate fruit trees planted in commercial orchards are the result of the union of two genotypes: the scion (which yields the fruit) and the rootstock (which serves as an interface between the scion and

Received for publication 4 Sept. 2013. Accepted for publication 10 Dec. 2013.

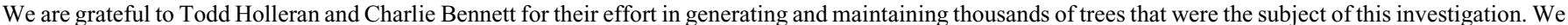

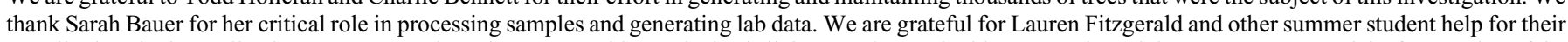

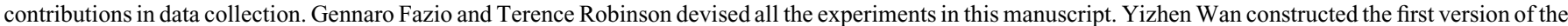

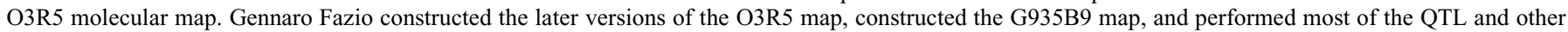

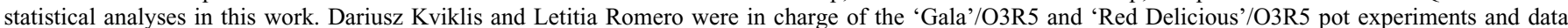
analysis. Richard Adams and David Strickland worked on the collection and data analysis of tree architecture data for breeding populations.

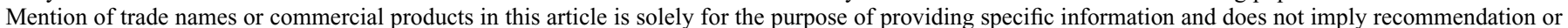
endorsement by the U.S. Department of Agriculture.

${ }^{1}$ Corresponding author. E-mail: gennaro.fazio@ars.usda.gov. 
the soil). This dual system has allowed for remarkable efficiencies in the development of new fruit cultivars because it divides breeding for the whole plant into its component environmental interactions and functions that require very different selection traits for improvement: the root system interactions with the soil (anchorage, soil profile exploration, water and nutrient absorption, and interaction with soil biota) and the scion (fruit production, quality, storability, photosynthesis, tree architecture, disease and insect resistance, and climate stress tolerance).

The benefits of selecting and using specific rootstocks for apple fruit production were likely realized by European fruit fanciers who used dwarf apple trees as the graft recipients of vigorous apple cultivars, and used the same dwarf or dwarfing apple combinations in espalier production of apple fruit (Monceau, 1768). Dwarfing and the induction of early fruit production (early bearing) when apples are grafted on 'Paradise' or Creeper stocks (Loudon, 1822) were probably what initially made these apple trees attractive, especially for small gardens or glasshouses. The rootstock cultivars English Paradise and Doucin Stock were recognized in the early 19th century as dwarfing and early-bearing (Lindley, 1828). The dwarfing properties of these stocks were recognized for their ability to shape trees into a pyramidal shape and increase the productivity of the orchard (Rivers, 1866). By the late 19th century these rootstocks were propagated clonally by rooted suckers (stools) under many different 'Paradise' rootstock names often representing mixtures of related genetic material (Wertheim, 1998) sometimes with different phenotypic characteristics and dwarfing effects. This confusion spurred an effort in the late 19th (Barron, 1889) and early 20th century to collect apple rootstock material from France, Germany, England, and The Netherlands, catalogue it and characterize it through detailed phenotypic observations at the East Malling Wye Agricultural Research Station (Hatton, 1917). This resulted in the description of the initial 'Malling' (M.xx) series of apple rootstocks M.1 to M.9, which contained both dwarfing and precocious types (M.3, M.4, M.8, M.9) and vigorous nonprecocious types (M.1, M.2, M.5, M.6, M.7) (Hatton, 1919). Several of these 'Malling' selections were found to belong to the Malus $\times$ domestica cluster when molecular markers were used to ascertain their relationships. Some (including M.8 and M.9) formed a tight cluster, suggesting close familial relationships (Fazio et al., 2011; Oraguzie et al., 2005). Some have ascribed the 'Paradise' dwarfing apple stocks to a Persian or Armenian origin (dwarf apple of Armenia) (Budagovskii, 1940; Rivers, 1866), whereas a recent genetic analysis shows a much closer relationship of 'Malling' rootstocks with old apple cultivars than with native Iranian (Persian) apple cultivars (Gharghani et al., 2009), possibly because the 'Paradise' stocks were the result of hybridization with old world cultivars or perhaps the sampling of Persian cultivars did not include dwarf apples.

In the 20th century several breeding programs located in important apple growing regions have used the dwarfing 'Malling' selections to breed new apple rootstocks more adapted to local pedo-climatic conditions (Cummins and Aldwinckle, 1974; Fischer, 1974; Spangelo et al., 1974; Watkins et al., 1973; Webster et al., 2000), resulting in several new rootstock cultivars with increased performance and disease resistance than the initial 'Malling' selections (Russo et al., 2007; Wertheim, 1998). M.9 and its clones and B.9, derived from M.8, represent the most planted apple rootstocks with over 50 million trees planted worldwide each year, a testament to the importance of the dwarfing and early-bearing genetics of these stocks. The use of dwarfing rootstocks has dramatically reduced worker injuries, the volume of protectant sprays used, and other cultural expenses while increasing per-acre productivity in apple orchard systems (Autio et al., 2011a; Marini et al., 2008). The use of dwarfing rootstocks also improves fruit quality and consistency.

The effect of dwarfing rootstocks on the phenotype of grafted scions can be measured at the cellular level with dramatic changes in gene expression of hundreds of scion genes (Jensen et al., 2010, 2012) and changes of scion wood properties (Tworkoski and Fazio, 2011; Tworkoski and Miller, 2007). The messenger system causing these changes is not well understood. Several models have been proposed for the dwarfing/early-bearing mechanism caused by M.9 and derived rootstocks on scion cultivars, such as changes in hydraulic conductivity (Atkinson et al., 2003), diverse mechanisms of plant hormone translocation (Kamboj et al., 1998, 1999; van Hooijdonk et al., 2010, 2011) and modification of graft union anatomy and auxin transport (Soumelidou et al., 1994a, 1994b), but none has been definitively identified as the causative agents of dwarfing. The effect of dwarfing rootstocks is slow and cumulative, causing an early set of terminal buds and stopping cumulative growth earlier in the season than vigorous rootstocks, resulting in an overall reduction of nodes in the scion (Seleznyova et al., 2003, 2008). From a tree architecture standpoint, the dwarfing mechanism has been described as faster physiological aging, related to the reduction in length of the first annual shoot of bottom branches and the high flowering on this shoot (Lauri et al., 2006). The influence of rootstocks on scion architecture can also encompass changes in the number of lateral branches (feathers) and their angle with the trunk (Fazio and Robinson, 2008). These rootstock-mediated changes seem to be physiologically different from the inherently dwarf or columnar scions and other heritable architecture types described in apple (Conner et al., 1998; Hemmat et al., 1997). Quantitative trait analysis and genetic mapping have greatly increased our understanding of the inheritance and control of several of these inherent apple architectural traits (Kenis and Keulemans, 2007; Segura et al., 2009). Within the Geneva, NY, apple rootstock breeding program, the dwarfing trait has been shown to be highly heritable and is easily recovered in rootstock breeding populations derived from M.9, M.8, and their relatives (Fazio and Mazzola, 2004).

An important step forward was the discovery and mapping of the dwarfing locus $(D w 1)$ derived from M.9 using the bulk segregant analysis approach using a cross between M.9 and Malus robusta R5. Dw1 was placed at the top of LG5 between markers CH03a09 and NZraAM18-700 (Celton et al., 2009; Pilcher et al., 2008), which, on the physical map, is in a region between $\mathrm{CH} 03 \mathrm{a} 09$ (7.63 Mb) and the telomere (Velasco et al., 2010). The sequence for marker NZraAM18-700 has not been revealed. Segregation of $D w 1$ could not explain the continuous variation for vigor control observed in the M. $9 \times \mathrm{R} 5$ population to study dwarfing (Pilcher et al., 2008). Several apple rootstock maps have been produced (Antanaviciute et al., 2012; Celton et al., 2009; Moriya et al., 2012) with the intent to increase the knowledge of rootstock-inherent and -mediated traits. These maps have been used to study the inheritance of root architecture in apple rootstocks (Fazio et al., 2009), fire blight (Erwinia 
amylovora) resistance (Gardiner et al., 2012), and absorption and translocation of nutrients by apple roots (Fazio et al., 2012a, 2013). Better, publicly available molecular markers associated with dwarfing will be very useful in apple rootstock breeding because of their potential to increase the proportion of highly desired dwarfs in breeding populations and reduce breeding cycles by 7 to 10 years. Map-based cloning of the dwarfing gene(s) will enhance the understanding of this trait and provide information useful for other members of Rosaceae. This study uses two rootstock populations to elucidate the location and effects of two major QTLs on rootstock-mediated early-bearing and dwarfing of apples.

\section{Materials and Methods}

Plant material and DNA extraction. Several segregating populations were used in this evaluation: 1) population named O3R5: 186 progeny from the interspecific cross between two apple rootstocks, 'Ottawa 3' (Spangelo et al., 1974) and R5. This population segregated for many important rootstock traits including resistance to fire blight (Gardiner et al., 2012), wooly apple aphid (Eriosoma lanigerum), powdery mildew (Podosphaera leucotricha) (Wan and Fazio, 2011), root architecture (Fazio et al., 2009), dwarfing, induction of early-bearing, yield efficiency, root suckering, and formation of burr knots and spines; 2) population G935B9: 126 progeny from a cross between G.935 and B.9 apple rootstocks; 3) population MM106G65: 216 progeny derived from a cross between 'Malling-Merton 106' (MM.106) and 'Geneva ${ }^{\circledR}$ 65' (G.65); 4) population G65G16: 187 progeny derived from a cross between G.65 and 'Geneva ${ }^{\circledR}$ 16' (G.16); 5) population B491G16: 45 progeny derived from a cross between 'Budagovsky 491' (B.491) and G.16;6) population G11P16: 53 progeny derived from a cross between 'Geneva ${ }^{\circledR} 11$ ' (G.11) and 'Polish 16' (P.16); and 7) population P2G11: 100 progeny derived from the cross between 'Polish 2' (P.2) and G.11.

DNA from was extracted using the DNeasy 96 plant miniprep kit (Qiagen, Valencia, CA) according to the manufacturer's specifications. DNA was quantified using Hoechst Dye (FluoReporter Blue Fluorometric dsDNA Quantitation Kit, Invitrogen F-2962; Life Technologies, Grand Island, NY) on a Tecan Spectrafluor Microplate Reader (Tecan Systems, San Jose, CA) (2- $\mu \mathrm{L}$ DNA sample, $48 \mu \mathrm{L}$ Tris-EDTA, $50 \mu \mathrm{L}$ Hoechst/Tris-Acetate-EDTA). Fluorescence was measured at $360 / 465 \mathrm{~nm}$ and compared with a serial dilution of calf thymus DNA.

Phenotypic evaluations. Although the establishment year of each of the populations may differ, all seedling populations from the crosses mentioned in this study underwent evaluation stages spanning 5 to 12 years designed for the purpose of determining the degree of dwarfing and induction of earlybearing by the rootstocks (Cummins et al., 1983; Johnson et al., 2001). Briefly, 20- to $30-\mathrm{cm}$ tall seedlings were planted in a rootstock nursery at the New York State Agricultural Experiment Station, Geneva, NY (NYSAES) in the spring of Year 1. The plants were allowed to grow for one season to strengthen the mother plant and the top was removed in the spring of Year 2 to stimulate sucker growth in preparation for propagation by stooling (Quamme and Brownlee, 1990). New shoots were mounded with sawdust during the second growing season to promote adventitious rooting on the shoots under the sawdust, and rooted shoots (rootstock liners) were harvested from mother plants in late fall of Year 2. Five to seven rootstock liners per genotype were planted in a tree nursery at NYSAES in the spring of Year 3 and were chip-budded with scions 'Mutsu' or 'Gala' at the end of summer of Year 3. In the spring of Year 4 the budded liners were topped to stimulate graft growth and budlings were trained to one shoot to produce an unbranched tree (whip). Finished trees were dug from the nursery in the fall of Year 4. Root systems were graded and tree height and diameter measurements made on finished trees. Finished trees were planted in a completely randomized design at a $1.5 \times 4-\mathrm{m}$ spacing in a field at NYSAES. Diameter and trunk cross-sectional area measurements at $15 \mathrm{~cm}$ above the graft union and number (or estimate) of flower clusters were collected on each tree during the spring of Years 5 to 13 . Number of fruit and weight of fruit per tree were measured during the fall of Years 5 to 13. Seedling mother plants were allowed to stool for Year 3 to collect measurements on liner quality, length, presence of spines, and level of adventitious rooting on cut stools in the fall-winter of Year 3. Leaf color (red or green) was recorded for the G935B9 population in Year 3. Mother plants were then allowed to grow in Years 4 to 7 in the stoolbed to evaluate vigor and flowering on 3-year-old shoots. In addition, the mother plants of the O3R5 population were mounded with sawdust and rooted shoots were cut in the fall of Years 5 to 8 to generate rootstock liners. Rooted liners from Year 5 were planted in a nursery in 2007 and were chip-budded with 'Brookfield Gala' scion, whereas liners from Year 8 were planted in a nursery in 2010 and chip-budded with 'Spur Red Delicious' scion. Three to five replicates of the 'Brookfield Gala' chip-budded plants were harvested from the nursery as dormant budlings ("sleeping eye tree") in Fall 2007 and planted in May 2008 in 14.5-L pots filled with 50\% screened topsoil (sandy loam, pH 6.5) and 50\% Cornell Potting Mix (50 peatmoss:50 vermiculite with $6.2 \mathrm{~kg} \cdot \mathrm{m}^{-3}$ lime, $1.25 \mathrm{~kg} \cdot \mathrm{m}^{-3}$ superphosphate, and $0.62 \mathrm{~kg} \cdot \mathrm{m}^{-3}$ calcium nitrate) in a completely randomized design. Trees were headed $6 \mathrm{~cm}$ above the scion bud to push bud growth and allowed to grow into their natural form without any nursery training (side-limbing). Standard drip irrigation was used to water the pots at field capacity everyday. Plants were manually fertilized with soluble fertilizer $[17 \mathrm{~N}-1.3 \mathrm{P}-14.1 \mathrm{~K}$ with micronutrients (Peters Professional Peat light Neutral Cal-Mag; Scotts, Marysville, OH)] at weekly intervals for 10 weeks (total of $26 \mathrm{~g}$ of soluble fertilizer for the vegetative season). Root system descriptions were collected before planting including root mass, root length, mean primary root angle, and fine root formation (Fazio et al., 2009). Measurements on bud burst, tree height, and number and length of feathers were measured at regular monthly intervals from May to October. Then plants were harvested and roots were washed to measure the whole plant, and root and scion wet and dry weight.

Two or three replicates of the 'Spur Red Delicious' finished trees were harvested from the nursery in Fall 2011 as fully grown finished trees and planted in May 2012 in 14.5-L pots with 50\% screened topsoil (sandy loam, $\mathrm{pH}$ 6.5) and 50\% Cornell Potting Mix (50 peatmoss:50 vermiculite with $6.2 \mathrm{~kg} \cdot \mathrm{m}^{-3}$ lime, $1.25 \mathrm{~kg} \cdot \mathrm{m}^{-3}$ superphosphate, and $0.62 \mathrm{~kg} \cdot \mathrm{m}^{-3}$ calcium nitrate) in a completely randomized design. Trees were allowed to grow in their natural form without any side-limbing. Standard drip irrigation was used daily to water the pots at field capacity. Plants were manually fertilized with soluble fertilizer $(17 \mathrm{~N}-1.3 \mathrm{P}-14.1 \mathrm{~K}$ with micronutrients) at weekly 
intervals for 10 weeks (total of $26 \mathrm{~g}$ of soluble fertilizer for the vegetative season). Measurements on those trees included final tree height, trunk cross-sectional area, number and length of feathers, and total canopy length (tree height + total length of feathers). Phenotypic data means, regressions, analyses of variance, and graphs were generated with a number of statistical packages including Minitab 16 (Minitab, State College, PA), Statistica 9 (Statsoft, Tulsa, OK), and JMP 10 (SAS Institute, Cary, NC).

GeNETIC MAPS. Genetic maps were constructed for the O3R5 and the G935B9 populations spanning all 17 apple chromosomes. The O3R5 pseudo-testcross map (Wan and Fazio, 2011) is comprised of a total of 529 markers [171 simple sequence repeat (SSR), 319 amplified length polymorphisms, 16 random amplified polymorphic DNA, and 17 expressed sequence tag (EST) derived sequence characterized amplified regions] constructed using JoinMap 4.1 mapping software (Van Ooijen, 2011). Marker order for SSR, EST, and other sequence-based markers was confirmed against the published physical sequence of apple (Velasco et al., 2010). This map data has already been used successfully for previous QTL analyses (Fazio et al., 2009, 2012a, 2013; Gardiner et al., 2012; Wan and Fazio, 2011). The G935B9 pseudo-testcross map is comprised of 1841 segregating single nucleotide polymorphism (SNP) loci resolved using the International RosBREED SNP Consortium (IRSC) Infinium $^{\circledR}$ II (Illumina, San Diego, CA) array developed through the RosBREED project (Chagné et al., 2012; Iezzoni, 2010) and used to genotype an M.27 × MM.106 apple rootstock population (Antanaviciute et al., 2012). Parental and progeny DNA was assayed with the 8788 SNP features (7867 Malus and 921 Pyrus) on the RosBREED apple array following the manufacturer's specifications (Illumina). Briefly, genomic DNA was amplified, fragmented, and hybridized to a BeadChip (Illumina) featuring probes for all SNPs. BeadChips were washed to remove non-hybridized DNA and an enzymatic single base extension reaction was performed using two differentially labeled nucleotides. Bead fluorescence was imaged using the HiScan BeadChip scanner and scan data were transferred into the GenomeStudio (Illumina) for SNP calling. According to the manufacturer's recommendations, SNP features were initially auto-scored using a GenCall score cutoff value of 0.15. All remaining features were then manually checked for accuracy in cluster calls, parent-child errors, and manually corrected according to the procedures outlined in the GenomeStudio Manual Chapter 3, and features displaying null alleles were eliminated from further analysis. SNP calls output from GenomeStudio (AA = homozygous for allele $1, \mathrm{AB}=$ heterozygous, $\mathrm{BB}=$ homozygous for allele 2) were transferred to Excel (Microsoft, Redmond, WA) for recoding in preparation for genetic map construction. Output was sorted by parental segregation type (Class $1=$ SNP heterozygous only in G.935, Class $2=$ SNP heterozygous only in B.9, Class $3=$ SNP heterozygous in both G.935 and B.9) and recoded into JoinMap 4.1 allele codes (Class $1=1 \mathrm{~m}$, ll; Class $2=\mathrm{nn}$, np; Class $3=\mathrm{hh}$, $\mathrm{hk}, \mathrm{kk}$ ) according to their segregation types. To keep marker names under the JoinMap 4.1 limit, the unique BeadChip address was used with an additional putative chromosome code (1 to 17) affixed at the end of the name. Mapping was performed using the recommended steps outlined in the JoinMap 4.1 manual using the multiple regression algorithm and the Kosambi function: 1) Grouping using LOD 3.0 and higher to generate groups of linked markers followed by inspection of strongest cross links (SCL) among groups and correction for misplaced markers having SCL value greater than $10 ; 2$ ) mapping with a Start Order corresponding to physical map; 3 ) elimination of markers for which a linkage phase could not be determined; 4) calculation options using markers with recombination fraction threshold of 0.4 and LOD greater than 2.0 with ripple value of one and goodness-of-fit threshold; and 5) three maps were calculated for each linkage group: one for each parent and a consensus map.

QTL ANALYSIS. QTL analysis was performed using the MapQTL 6 software package (Kyazma, Wageningen, The Netherlands). Briefly, a preliminary QTL analysis was performed by a Kruskal-Wallis test on all traits as described in the software instruction manual. Subsequently, interval mapping using the regression analysis method and the LOD test statistic with a step size of one was performed to identify putative QTL regions as described in the MapQTL 6 software manual. The resulting outputs were parsed for QTLs having LOD values of 3.0 and higher and selected for further analysis. Empirical 95\% confidence limits (chromosome and genome wide) for the LOD statistic were calculated for all traits using 10,000 permutations to ensure the statistical validity of the QTL against falsepositives. The location of all QTL peaks with LOD 3.0 and higher was extracted as well as values for mean parental allele combination contribution $(\mu / \mathrm{ac}, \mu / \mathrm{ad}, \mu / \mathrm{bc}, \mu / \mathrm{bd})$, variance, and percent variance explained by interval. In MapQTL 6, the contribution of the parental alleles is coded so that marker alleles "a," "b," or " $1 \mathrm{~m}$ "; "ll" are derived from Parent 1 ('Ottawa 3' and G.935) and alleles “c," "d," or "nn"; and "np" are from Parent 2 (R5 and B.9). As recommended by the MapQTL 6 manual, the location of the QTL peaks was refined by multiple-QTL mapping analysis, which uses nearby markers as cofactors in the analysis.

LOCUS INTERACTION ANALYSIS. Individual phenotypic data (parametric) and corresponding JoinMap 4.1-coded marker data (non-parametric) were entered in a Statistica 9 or JMP 10 workbook for marker model-building and testing. The main effects and interaction effects on several phenotypic variables were examined by using markers linked to $D w 1$ and $D w 2$ as the main effects and the interaction $(D w 1 \times D w 2)$ using the generalized linear models procedure in Statistica 9.

\section{Results}

Trait correlation. The overall Pearson correlation coefficient in tree size between the rootstock mother plants and derived 3-year-old grafted finished trees of four breeding populations (B491G16, G11P16, MM106G65, P2G11) was 0.579 $(P=0.000)$. When populations were analyzed separately (Fig. 1), their regression coefficients were unique to each population and showed a significant correlation between mother plant size and finished tree size. Similarly, the correlation between the maximum length of 1-year shoots of mother plants and mean trunk diameter of 4-year-old finished trees of the O3R5 population was $0.552(P<$ $0.05)$. There was a significant negative correlation $(-0.21, P<$ 0.05 ) between trunk diameter of 4-year-old trees and the number of flower clusters on the same trees in the O3R5 population. Similarly, the correlation between number of fruit harvested on replicated finished trees and trunk diameters in 2011 for the G935B9 population was $-0.30(P<0.05)$. Correlation coefficients of a similar magnitude have been calculated for many progenies throughout the history of the Geneva ${ }^{\circledR}$ breeding program. 


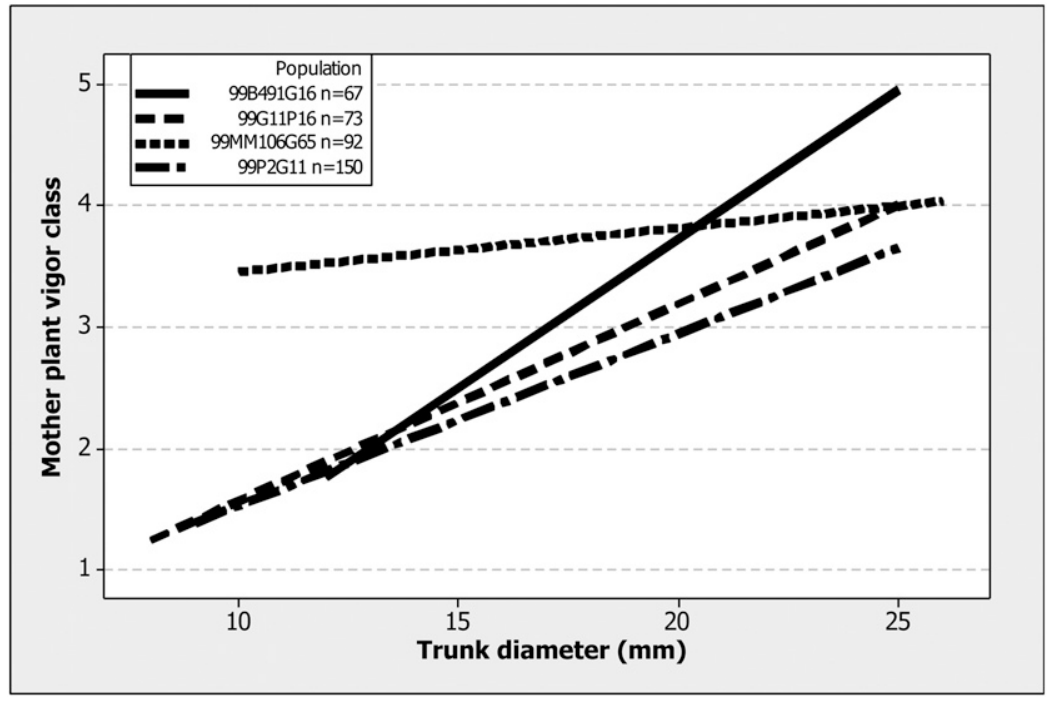

Fig. 1. Regression lines $(P<0.000)$ between mother plant stature (increasing vigor classes one through five) and tree diameter of 3-year-old grafted trees for four apple rootstock breeding populations (B491G16, G11P16, MM106G65, P2G11), where mother plants were allowed to grow after liners were harvested for grafting replicated field trials. Three of the four slopes have similar values because they are derived from crosses between dwarfing parents (B.491, P.2, G.11, P.16, and G.16) indicating that dwarfing progeny are easily recovered in these crosses because the dwarfing loci can reach homozygosity. The line with a different slope is a cross of MM.106 (non-dwarfing) by G.65 (dwarfing).

G.935 $\times$ B.9 SNP GENETIC MAP. Supplementary Tables 1 to 3 contain the results of the genetic linkage map construction. A graphical example of the alignments of such maps is given in Figure 4. The genetic map had a total length of $942 \mathrm{cM}$ and spanned all 17 chromosomes of apple for the female parent (G.935); it was constructed with 762 SNP markers that were heterozygous only in G.935. The genetic map for the male parent B.9 had a total length of $1530 \mathrm{cM}$; it spanned all 17 chromosomes with 773 SNP markers that were heterozygous only in B.9. Markers heterozygous in both parents allowed for the construction of a consensus map of 1841 markers with a total length of $1414 \mathrm{cM}$. Concordance between genetic map assignment and physical map location was good for 1597 markers. Chromosomal assignment for 244 of the 1841 total mapped markers (13.25\%) was not in accordance with published physical map location of the SNPs.

QTL DISCOVERY AND VALIDATION. The discovery of $D w 1$ and $D w 2$ within the Geneva ${ }^{\circledR}$ breeding program was initially achieved using a genome scan approach (Patocchi et al., 2005) with several breeding populations (data not included). This was followed by a more rigorous QTL mapping approach with progeny from the O3R5 cross under multiple experimental conditions (traits; QTL locations are described in Tables 1 and 2) and validated with progeny from a related breeding population (G935B9). All experiments were in concordance that the first dwarfing locus Dw1 is located on the top of LG05 between markers Hi15e04 and Hi09b04. The second dwarfing locus, $D w 2$, is located in the middle of LG11 between markers Ch02d08 and C13243. The induction of early-bearing Ebl is to some extent colocated with $D w 1$, the highest LOD being observed in the C3843x-Hi04a08 interval and Eb2 colocated with $D w 2$ in the interval Ch02d08 and C13243. QTLs corresponding to mean number of fruit per tree (Table 2) did not colocate with $D w 1$, but a recurring QTL ( $F r N 1)$ for years 2011 and 2012 colocated with $D w 2$ and a new QTL for the same trait was identified on LG16. The FrN1 QTL was validated in the G935B9 population where cumulative fruit yields seemed to be modulated more by $D w 2$ than $D w 1$ (Fig. 6). Locations for $D w 1$ and $D w 2$ are similar in the SNP maps of the G935B9 populations for own-rooted and grafted trees. The red leaf color segregating in the G935B9 population, used to validate map and QTL detection ability, coincided with the published location of the Rni/MdMYB10 gene affecting apple anthocyanin production (Espley et al., 2006).

LOCUS INTERACTION ANALYSIS. In the O3R5 progeny, the most dwarfing rootstocks were the ones that inherited both $D w 1$ and $D w 2$ from the dwarfing parent 'Ottawa 3', because only heterozygotes at each locus were expected in the progeny. These were also the most early-bearing inducing rootstocks. In the heterozygous state, each dwarfing locus reduced vigor of the trees independently of the other (Table 3; Fig. 2). In the G935B9 population, a similar trend was observed, but now because both parents were heterozygous for $D w 1$ and $D w 2$, the homozygous classes could be studied and compared. Vigorous trees were obtained from rootstocks that were homozygous for the non-dwarfing alleles of $D w 1$ regardless of the allelic status of $D w 2$ (Table 4; Fig. 3). The same is also true with $D w 2$, in which individuals homozygous for the nondwarfing allele generated vigorous plants regardless of the allelic status of $D w 1$. The smallest trees were obtained with rootstocks that were homozygous at both loci. Intermediately dwarfing trees were obtained in the other heterozygous combinations. The regression model based on the main effects of $D w 1$ and $D w 2$ and their interaction in the G935B9 population was statistically significant $\left(R^{2}=0.80, P<0.0001\right)$, the predictive power being the greatest when seedlings were homozygous at one or both loci (Fig. 5).

\section{Discussion}

The ability to reduce tree vigor by apple rootstocks has been well characterized. There are many factors that influence scion vigor: the influence of the rootstock, soil fertility and water availability, soilborne diseases, and scion genetics. Therefore, if $\mathrm{T}$ was the size of a grafted scion (S) on a rootstock $(\mathrm{R})$ in orchard A, then the size of such tree at maturity would be $\mathrm{T}=$ $A_{\text {fertility }}+A_{\text {water }}+A_{\text {disease }}+A_{\text {system }}+S_{\text {vigor }}+R_{\text {dwarfing where }}$ $A_{\text {fertility }}$ is the fertility of orchard $A$ soil, $A_{\text {water }}$ is the availability of water in orchard $\mathrm{A}, \mathrm{A}_{\text {disease }}$ is the presence of diseases that decreases the vigor of the scion, $A_{\text {system }}$ is the orchard system used, $\mathrm{S}_{\mathrm{vigor}}$ is the inherent vigor of the scion (e.g., a 'Honeycrisp' scion is less vigorous than a 'Fuji' scion), and $\mathrm{R}_{\mathrm{dwarfing}}$ is the rootstock genetic potential for dwarfing the scion. Because the rootstock is the conduit for water and nutrients and can be susceptible or resistant to diseases, the genetic composition of such rootstock has been shown to interact with all such variables. For example, water and nutrient availability can be drastically influenced by the rootstock (Cohen et al., 2007; 
Table 1. Summary table of phenotypic data collected on composite apple trees (scion/rootstock) or own-rooted apple rootstock plants, the abbreviated trait names (referred to in Table 2), and type of analyses they were used in.

\begin{tabular}{|c|c|c|c|}
\hline Abbreviated name & Trait description & $\begin{array}{l}\text { Scion/rootstock population } \\
\text { (planting) }\end{array}$ & Analysis \\
\hline MeanDiam & $\begin{array}{l}\text { Mean of trunk diameters for each } \\
\text { rootstock genotype's tree } \\
\text { replicates in the same orchard } \\
\text { experiment }\end{array}$ & $\begin{array}{l}\text { 'Brookfield Gala'/O3R5 (orchard) } \\
\text { 'Golden Supreme'/G935B9 } \\
\text { (orchard) } \\
\text { 'Red Delicious'/O3R5 (potted trees) }\end{array}$ & $\begin{array}{l}\text { Correlation, quantitative trait } \\
\text { loci (QTL) discovery, mean } \\
\text { comparison, marker } \\
\text { regression model }\end{array}$ \\
\hline MeanCluster & $\begin{array}{l}\text { Mean number of flower clusters for } \\
\text { each rootstock genotype's tree } \\
\text { replicates in the same orchard } \\
\text { experiment (second growing } \\
\text { season) }\end{array}$ & 'Brookfield Gala'/O3R5, (orchard) & $\begin{array}{l}\text { Correlation, QTL discovery, } \\
\text { mean comparison, marker } \\
\text { regression model }\end{array}$ \\
\hline FruitCount(20xx) & $\begin{array}{l}\text { Mean number of fruit for each } \\
\text { rootstock genotype's tree } \\
\text { replicates in the same orchard } \\
\text { experiment (year) }\end{array}$ & $\begin{array}{l}\text { 'Brookfield Gala'/O3R5, (orchard), } \\
\text { 'Golden Supreme'/G935B9 } \\
\text { (orchard) }\end{array}$ & $\begin{array}{l}\text { Correlation, QTL discovery, } \\
\text { mean comparison, marker } \\
\text { regression model }\end{array}$ \\
\hline MXL & $\begin{array}{l}\text { Maximum length of 1-year shoots of } \\
\text { mother plants in stool bed }\end{array}$ & O3R5 (mother plants) & $\begin{array}{l}\text { Correlation, QTL discovery, } \\
\text { mean comparison, marker } \\
\text { regression model }\end{array}$ \\
\hline Trunk Diameter & $\begin{array}{l}\text { Mean of trunk diameters for tree } \\
\text { replicates in the same orchard } \\
\text { experiment }\end{array}$ & $\begin{array}{l}\text { 'Mutsu'/B491G16 (orchard), } \\
\text { 'Mutsu'/G11P16 (orchard), } \\
\text { 'Mutsu'/MM106G65 (orchard), } \\
\text { 'Mutsu'/P2G11 (orchard) }\end{array}$ & Trait correlation analysis \\
\hline Mother Plant Vigor Class & $\begin{array}{l}\text { Visual assessment of plant vigor of } \\
\text { own rooted 5-year-old mother } \\
\text { plants into five vigor classes }\end{array}$ & $\begin{array}{l}\text { B491G16, G11P16, MM106G65, } \\
\text { P2G11 (mother plants) }\end{array}$ & Trait correlation analysis \\
\hline Mean Tree Height & $\begin{array}{l}\text { Mean of scion tree height } \\
\text { measurements from graft union to } \\
\text { tallest apex of experimental } \\
\text { replicates }\end{array}$ & $\begin{array}{l}\text { 'Brookfield Gala'/O3R5 (potted } \\
\text { trees) } \\
\text { 'Red Delicious'/O3R5 (potted trees) }\end{array}$ & $\begin{array}{l}\text { Correlation, QTL discovery, } \\
\text { mean comparison, marker } \\
\text { regression model }\end{array}$ \\
\hline Mean Total Canopy Length & $\begin{array}{l}\text { Mean of scion canopy measurements } \\
\text { for each branch including main } \\
\text { trunk of experimental replicates }\end{array}$ & $\begin{array}{l}\text { 'Brookfield Gala'/O3R5 (potted } \\
\text { trees) } \\
\text { 'Red Delicious'/O3R5 (potted trees) }\end{array}$ & $\begin{array}{l}\text { Correlation, QTL discovery, } \\
\text { mean comparison, marker } \\
\text { regression model }\end{array}$ \\
\hline Rootstock Height & $\begin{array}{l}\text { Maximum height of 4-year-old } \\
\text { mother plants }\end{array}$ & $\begin{array}{l}\text { 'Golden Supreme'/G935B9 } \\
\text { (orchard) }\end{array}$ & $\begin{array}{l}\text { Correlation, QTL discovery, } \\
\text { mean comparison, marker } \\
\text { regression model }\end{array}$ \\
\hline Rootstock Leaf Color & Red leaf vs. green leaf & G935B9 (mother plants) & QTL validation, map validation \\
\hline
\end{tabular}

Fallahi et al., 2011; Fazio et al., 2012a, 2012b, 2013) and tolerance to replant disease affects the size and productivity of the apple tree (Auvil et al., 2011; Leinfelder and Merwin, 2006; Mazzola, 1998). Therefore, genetic variation for these traits within apple rootstocks will have an effect on tree size and productivity. The dwarfing phenotype can also be observed when interstems of dwarfing rootstocks are used between a vigorous rootstock and a vigorous scion (Koike and Tsukahara, 1988) and the dwarfing effect is proportional to the size of the dwarfing interstems (Carlson and Oh, 1975). This study shows that in the Geneva ${ }^{\circledR}$ apple rootstock breeding program, there are at least two genetic factors being used in breeding new rootstocks that affect the rootstock ability to reduce scion vigor. The effect of these two loci in the orchard is evidenced in the scion by the early termination of growth (apical and radial), which cumulatively season after season results in a dramatic dwarfing effect.

Within breeding populations of the Geneva ${ }^{\circledR}$ breeding program, the ability of individual rootstocks to dwarf scions is correlated with the own-rooted tree size of each rootstock genotype (Fig. 1). The QTLs for $D w 1$ and $D w 2$ were significant whether measured on the own-rooted mother plants or on the finished trees derived from those mother plants. This suggests that it may be possible to select dwarfing apple rootstocks based on the size that mother plants reach after 3 to 5 years. Given similarities between genomes of Rosaceae tree crops (Dirlewanger et al., 2004), it may be possible to select dwarfing rootstocks or breeding material in tree crops that currently lack dwarfing precocious rootstocks [e.g. pear (Pyrus communis)] based only on vigor of mother plants in the stool beds.

The predictive ability of a two-locus model to explain dwarfing phenotypic variation on finished trees was tested in the G935B9 population. This model used the allelic constitution of the main dwarfing loci $D w 1$ and $D w 2$ to predict the diameter of the trees. Given that both parents were heterozygous at both loci, eight classes of progeny were predicted (Table 4), some having nearly an identical predicted dwarfing effect. Although the model fit well in the higher and lower ranges of the curve, it was somewhat variable in the middle of the curve. In other words, a plot of residuals vs. predicted tree size shows greater scattering in the middle of the curve. This may be the result of differential partial dominance in the effects 
Table 2. Results from the quantitative trait loci (QTL) analyses combining phenotypic data from orchard and potted experiments on compound apple trees (scion/rootstock) and own-rooted apple rootstock plants including designated QTL names, level of significance expressed in LOD values obtained with the QTL analyses, genomic intervals represented by flanking markers, population/experiment that generated the trait data, and trait description.

\begin{tabular}{|c|c|c|c|c|c|}
\hline QTL name & $\begin{array}{l}\text { Significance } \\
\text { (LOD) }\end{array}$ & $\begin{array}{c}\text { Genomic interval }^{\mathrm{z}} \text { represented } \\
\text { by flanking markers }\end{array}$ & $\begin{array}{l}\text { Linkage } \\
\text { group } \\
\text { (LG) }\end{array}$ & Population/expt. & Trait description \\
\hline$\overline{D w 1}$ & 7.2 & Hi15e04-Hi09b04 & LG05 & $\begin{array}{l}\text { 'Brookfield Gala'/ } \\
\text { O3R5 (orchard), } \\
\text { stoolbed }\end{array}$ & MeanDiam, MXL \\
\hline$D w 2$ & 6.4 & $\mathrm{Ch02d08-C13243}$ & LG11 & $\begin{array}{l}\text { 'Brookfield Gala'/ } \\
\text { O3R5 (orchard), } \\
\text { stoolbed }\end{array}$ & MeanDiam, MXL \\
\hline$E b 1$ & 7.1 & $\mathrm{C} 3843 \mathrm{x}-\mathrm{Hi} 04 \mathrm{a} 08$ & LG05 & $\begin{array}{l}\text { 'Brookfield Gala'/ } \\
\text { O3R5 (orchard) }\end{array}$ & MeanCluster \\
\hline$E b 2$ & 7.6 & Ch02d08-C13243 & LG11 & $\begin{array}{l}\text { 'Brookfield Gala'/ } \\
\text { O3R5 (orchard) }\end{array}$ & MeanCluster \\
\hline $\operatorname{FrN1}(2011)$ & 7.0 & Ch02d08-C13243 & LG11 & $\begin{array}{l}\text { 'Brookfield Gala'/ } \\
\text { O3R5 (orchard) }\end{array}$ & FruitCount $(20 \mathrm{xx})$ \\
\hline $\operatorname{FrN2(2011)}$ & 3.5 & Hi22f06-Ch01f03 & LG16 & $\begin{array}{l}\text { 'Brookfield Gala'/ } \\
\text { O3R5 (orchard) }\end{array}$ & FruitCount $(20 \mathrm{xx})$ \\
\hline FrN1(2012) & 7.1 & Ch02d08-C13243 & LG11 & $\begin{array}{r}\text { 'Brookfield Gala'/ } \\
\text { O3R5 (orchard) }\end{array}$ & FruitCount $(20 \mathrm{xx})$ \\
\hline$D w 1$ & 2.7 & Hi15e04-Hi09b04 & LG05 & $\begin{array}{l}\text { 'Brookfield Gala'/ } \\
\text { O3R5 (pots) }\end{array}$ & Mean Tree Height \\
\hline$D w 2$ & 3.9 & Ch02d08-C13243 & LG11 & $\begin{array}{l}\text { 'Brookfield Gala'/ } \\
\text { O3R5 (pots) }\end{array}$ & Mean Tree Height \\
\hline$D w 2$ & 3.0 & Ch02d08-C13243 & LG11 & $\begin{array}{l}\text { 'Brookfield Gala'/ } \\
\text { O3R5 (pots) }\end{array}$ & Total Canopy Length \\
\hline$D w 1$ & 4.2 & Hi15e04-Hi09b04 & LG05 & $\begin{array}{l}\text { 'Red Delicious'/ } \\
\text { O3R5 (pots) }\end{array}$ & MeanDiam \\
\hline$D w 1$ & 3.8 & Hi15e04-Hi09b04 & LG05 & $\begin{array}{l}\text { 'Red Delicious'/ } \\
\text { O3R5 (pots) }\end{array}$ & $\begin{array}{l}\text { Mean Total Canopy } \\
\text { Length }\end{array}$ \\
\hline$D w 1$ & 4.7 & $\begin{array}{c}\text { RosBREEDSNP_SNP_TC_984342_- } \\
\text { Lg5_01694_MAF10_1654238_exon3- } \\
\text { RosBREEDSNP_SNP_GA_4178848_- } \\
\text { Lg5_01566_MAF50_1687376_exon1 }\end{array}$ & LG05 & $\begin{array}{l}\text { 'Golden Supreme'/ } \\
\text { G935B9 (orchard) }\end{array}$ & MeanDiam \\
\hline$D w 2$ & 6.9 & $\begin{array}{l}\text { RosBREEDSNP_SNP_GA_12188459_ } \\
\text { Lg11_00240_MAF10_MDP0000713484_- } \\
\text { exon1-RosBREEDSNP_SNP_GA_8445216_ } \\
\text { Lg11_00185_MAF40_531216_exon5 }\end{array}$ & LG11 & $\begin{array}{l}\text { 'Golden Supreme'/ } \\
\text { G935B9 (orchard) }\end{array}$ & MeanDiam \\
\hline$D w 1$ & 3.7 & $\begin{array}{l}\text { RosBREEDSNP_SNP_TC_984342_Lg5_01694_ } \\
\text { MAF10_1654238_exon3-RosBREEDSNP_- } \\
\text { SNP_GA_4178848_Lg5_01566_MAF50_- } \\
\text { 1687376_exon1 }\end{array}$ & LG05 & $\begin{array}{l}\text { 'Golden Supreme'/ } \\
\text { G935B9 (orchard) }\end{array}$ & Rootstock Height \\
\hline$D w 2$ & 6.3 & $\begin{array}{l}\text { RosBREEDSNP_SNP_GA_12188459_Lg11_- } \\
\text { 00240_MAF10_MDP0000713484_exon1- } \\
\text { RosBREEDSNP_SNP_GA_8445216_Lg11_ } \\
\text { 00185_MAF40_531216_exon5 }\end{array}$ & LG11 & $\begin{array}{l}\text { 'Golden Supreme'/ } \\
\text { G935B9 (orchard) }\end{array}$ & Rootstock Height \\
\hline FrN1(2012) & 4.5 & $\begin{array}{l}\text { RosBREEDSNP_SNP_GA_12188459_Lg11_- } \\
\text { 00240_MAF10_MDP0000713484_exon1- } \\
\text { RosBREEDSNP_SNP_GA_8445216_Lg11_ } \\
\text { 00185_MAF40_531216_exon5 }\end{array}$ & LG11 & $\begin{array}{l}\text { 'Golden Supreme'/ } \\
\text { G935B9 (orchard) }\end{array}$ & Rootstock Height \\
\hline Rni/MdMYB10 & 27.15 & GDsnp02482-GDsnp00467 & LG09 & $\begin{array}{l}\text { G935B9 (mother } \\
\text { plants) }\end{array}$ & Rootstock Leaf Color \\
\hline
\end{tabular}

${ }^{\mathrm{z}}$ Markers with the Ch or Hi designation are described in Liebhard et al. (2002) and Silfverberg-Dilworth et al. (2006), markers with the C designation are described in Wang et al. (2012), and markers with RosBREED or GD designation are described in Chagné et al. (2012). $\mathrm{LOD}=\log$ of odds.

of both loci, which was not calculated in the model. Another explanation may be additional loci that may play a smaller role in vigor reduction of the scion. Even the parents, although being genetically similar at the dwarfing loci, have significantly different dwarfing potential as measured in field trials around the world (Autio et al., 2011b; Auvil et al., 2011; Robinson 
Table 3. Least square (LS) means estimated for the trunk diameters of compound apple trees (scion/rootstock) of 'Brookfield Gala' grafted onto the O3R5 apple rootstock segregating population showing the $D w 1 \times D w 2$ interaction originating from segregation of dwarfing heterozygous loci in parent 'Ottawa 3' $(D w 1=1 \mathrm{~m}$ and $11, D w 2=1 \mathrm{~m}$ and 11) and homozygous non-dwarfing loci in parent 'Robusta 5'.

\begin{tabular}{llcc}
\hline$D w 1$ & $D w 2$ & Trunk diam LS means $(\mathrm{mm})$ & SE \\
\hline $\operatorname{lm}$ & $\mathrm{lm}$ & 69.47667 & 2.494386 \\
$\operatorname{lm}$ & 11 & 61.96491 & 2.861257 \\
11 & $\mathrm{~lm}$ & 63.73437 & 2.204747 \\
11 & 11 & 45.26754 & 2.023214 \\
\hline
\end{tabular}

"Allele "l" is dwarfing and allele " $\mathrm{m}$ " is normal.

et al., 2011a; Russo et al., 2007), where G.935 tends to produce a tree that is $20 \%$ more vigorous than a tree on B.9. Other factors relating to nutrition, disease resistance, scion compatibility, early-bearing induction, water use efficiency, and root architecture may explain variation not resulting from the dwarfing genes.

In the O3R5 pot trials in which two different scions were used, the influence of the $D w 2$ QTL was absent in the weaker scion ('Spur Red Delicious'), possibly indicating the inability of $D w 2$ to be expressed with a weaker scion. The 'Gala'/O3R5 combination did display both dwarfing QTLs even in pots where water and nutrient conditions were maintained at optimum levels. This finding may have implications for breeding new rootstocks because specific rootstock/scion combinations may result in optimum growth and production of a tree. Semidwarfing apple rootstocks G.210 and G.969 (O3R5 derivatives) could be used for cultivation of weaker scions of 'Red Delicious' or 'Honeycrisp', whereas dwarfing rootstock G.214 may perform better with vigorous scions of 'Fuji' or 'Mutsu'.

The ability to induce early flowering/bearing in scion cultivars, otherwise known as precocity, is a major selection criterion for breeding dwarfing apple rootstocks. Precocity requires 6 to 8 years to evaluate in the orchard and is one of the major targets for marker-assisted selection in the Geneva ${ }^{\circledR}$ breeding program. Although precocity has been associated with dwarfing (Webster and Warrington, 1995), very little is known about its inheritance in apple rootstocks. Early observations in the Geneva ${ }^{\circledR}$ breeding program indicated that dwarfing and

Table 4. Least square (LS) means estimated for the trunk diameters of compound apple trees (scion/rootstock) of 'Golden Supreme' scion grafted onto the G935B9 apple rootstock segregating population showing the $D w 1 \times D w 2$ interaction originating from segregation of heterozygous loci in parents G.935 and B.9. ${ }^{\mathrm{z}}$

\begin{tabular}{lccc}
\hline$D w 1$ & $D w 2$ & Trunk diam LS means $(\mathrm{mm})$ & SE \\
\hline $\mathrm{hh}$ & $\mathrm{hh}$ & 37.416667 & 1.4527052 \\
$\mathrm{hh}$ & $\mathrm{hk}$ & 37.683333 & 1.4527052 \\
$\mathrm{hh}$ & $\mathrm{kk}$ & 39.050000 & 2.5161593 \\
$\mathrm{hk}$ & $\mathrm{hh}$ & 37.716667 & 1.1861289 \\
$\mathrm{hk}$ & $\mathrm{hk}$ & 28.133368 & 0.8163499 \\
$\mathrm{hk}$ & $\mathrm{kk}$ & 22.780000 & 1.5913589 \\
$\mathrm{kk}$ & $\mathrm{hh}$ & 36.770000 & 1.5913589 \\
$\mathrm{kk}$ & $\mathrm{hk}$ & 21.972875 & 1.2580796 \\
$\mathrm{kk}$ & $\mathrm{kk}$ & 18.250000 & 2.5161593 \\
\hline
\end{tabular}

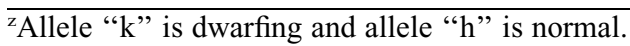

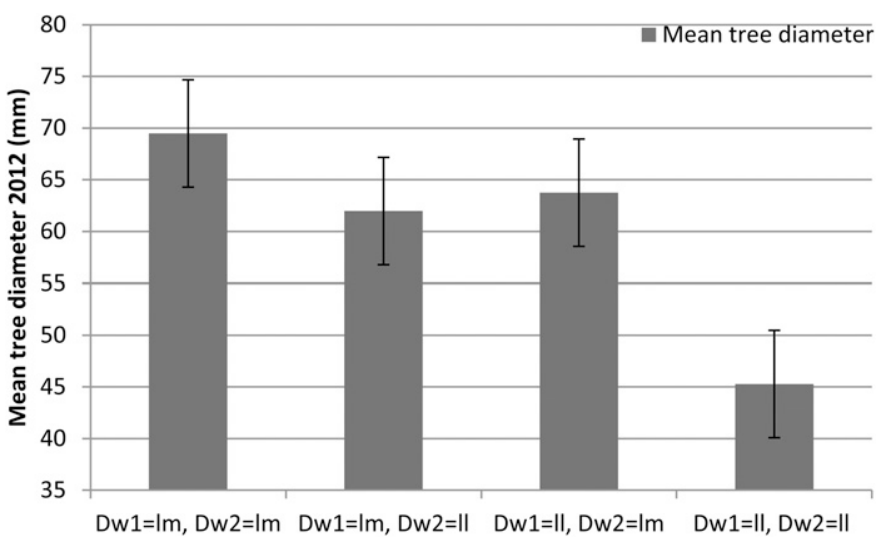

Fig. 2. Interaction between $D w 1$ and $D w 2$ observed in the progeny of a cross between a vigorous apple parent (R5) and a dwarfing parent heterozygous at both loci ('Ottawa 3'). Codes $1 \mathrm{~m}$ and 11 are the same as in the JoinMap (Van Ooijen, 2011) and MapQTL (Kyazma, Wageningen, The Netherlands) software; they are assigned to alleles contributed by Parent 1 (Ottawa3) and represent allele constitution of progenies (in this case in a testcross configuration). Whiskers denote the $95 \%$ confidence interval. Allele " 1 " is dwarfing and allele " $\mathrm{m}$ " is normal. Maximum dwarfing is achieved in rootstocks that possess the 'Ottawa 3' allele at both dwarfing loci. Individuals that feature the 'Ottawa 3' allele at one of either loci show intermediate dwarfing capacity, whereas individuals possessing none show no dwarfing capacity.

precocity were loosely associated genetically and as such the induction of early-bearing has been relatively easy to recover in the progeny of apple rootstock crosses. In our research, earlybearing induction is influenced by two loci (Eb1 and $E b 2)$, which seem to colocate with $D w 1$ and $D w 2$. The Gala/O3R5 orchard data show that although the QTLs may be colocated,

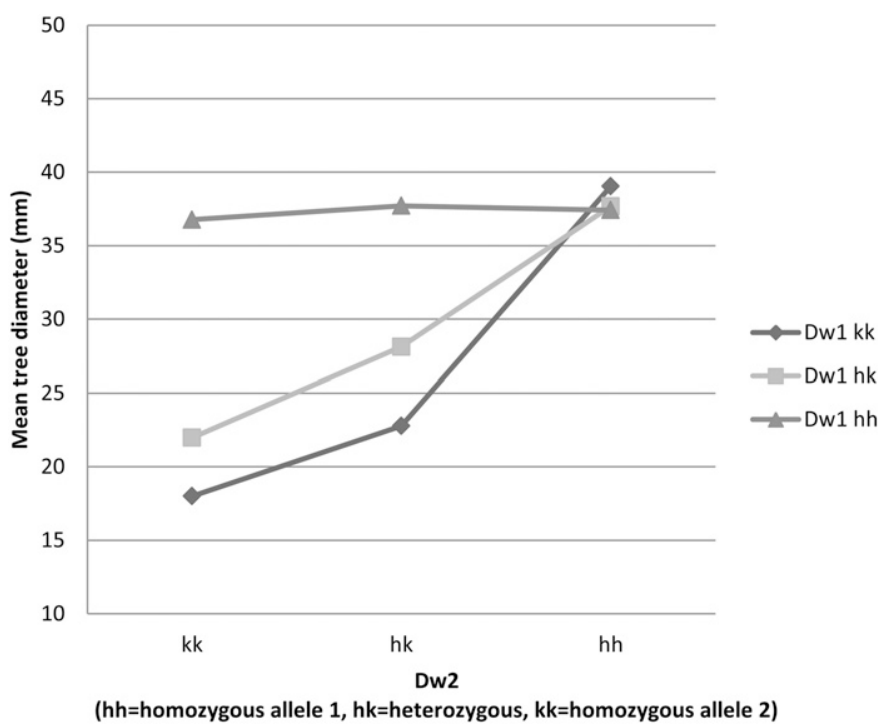

Fig. 3. Interaction between $D w 1$ and $D w 2$ as observed in the progeny of two double heterozygous apple parents (G.935 and B.9). Codes hh, hk, and kk are the same as in the JoinMap (Van Ooijen, 2011) and MapQTL (Kyazma, Wageningen, The Netherlands) software; they are assigned to alleles contributed by both heterozygous (hk) and represent allele constitution of progenies possible in this cross. Allele " $\mathrm{k}$ " is dwarfing and allele " $\mathrm{h}$ " is normal. What is peculiar about these observations is that homozygous individuals for non-dwarfing alleles at either $D w 2$ or $D w 1$ invalidate the effect of the dwarfing ability of the other dwarfing locus. In addition, the heterozygote individuals at either locus have somewhat of a different capacity to dwarf the scion, where $D w 2$ seems to dwarf slightly less than $D w 1$. 


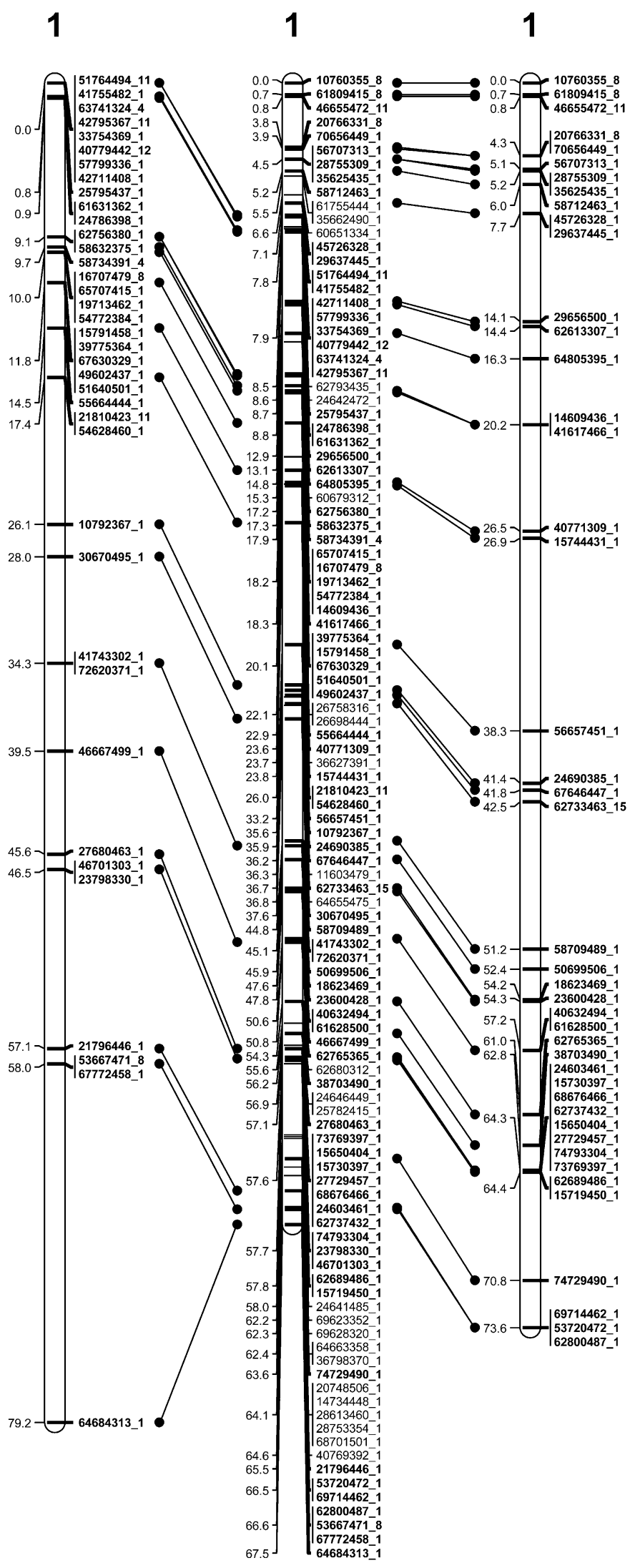

Fig. 4. Graphical representation of apple linkage Group 1 genetic maps for G.935 (left) consensus (middle), and B.9 (right) map developed with the RosBREED Infinium single nucleotide polymorphism (SNP) chip. In this figure the chip address was used instead of the SNP name according to Chagné et al. (2012). Full map information for G.935, B.9, and consensus maps the traits are not highly correlated, suggesting the influence of other environmental or genetic factors in the expression of such trait. Loss of juvenility and subsequent induction of flowering in apple seedlings seem to be related to the distance from the root system or the amount of trunk growth (Aldwinckle, 1975; Zimmerman, 1972). Increasing interstem size of early-bearing inducing rootstocks can also lessen the juvenility stage significantly (Carlson and Oh, 1975) suggesting that the interstem tissue might reduce the amount of an unidentified signal originating from the roots causing juvenility in the scions (van Hooijdonk et al., 2011). The genetic factors inducing earlybearing identified in this research may be used in the process of fast breeding (Volz et al., 2009) to decrease the juvenility stage of grafted scions and increase the efficiency of apple breeding programs.

Two QTLs ( $F r N 1$ and $F r N 2$ ) associated with the number of fruit produced by each Gala/O3R5 tree were identified in two seasons. The first colocated with $D w 2, E b 2$, and a fine root trait QTL (Fazio et al., 2009) on LG11, whereas a second QTL of minor effect located in the middle of LG 16 was detected for only one season. The FrN1 QTL was also validated in the 'Golden'/G935B9 planting over 2 years. The cumulative fruit number (Fig. 6) seems to be modulated by a factor on LG11 that colocated with $D w 2$. The dwarfing locus $D w 1$ did not seem to have much effect on early fruit production other than homozygous non-dwarfing rootstocks being less productive than the other classes. Early and steady production of apples is important for modern fruit production because high-density training systems require a significant capital investment that needs early returns to be profitable (Robinson et al., 2011b).

The new genetic maps of apple rootstocks G.935 and B.9 and a consensus map featuring 1841 SNP markers analyzed on the IRSC Illumina Infinium ${ }^{\circledR}$ II array (Chagné et al., 2012; Iezzoni, 2010) were used for QTL validation of the O3R5 QTLs. Genetic mapping revealed that 1597 of 1841 SNP markers agreed with the chromosomal assignment based on the published physical map of apple; however, 244 SNP (13.25\%) did not match with the physical map, in agreement with the incongruence rate (13.7\%) reported by Antanaviciute et al. (2012) using the same array on a similar apple rootstock progeny. Incongruence has been explained partially by probes detecting more than one locus, rearrangements within the genome, indels, and misassignment of sequences in the 'Golden Delicious' genome sequence (Khan et al., 2012). A higher recombination rate was detected in the B.9 parent than the G.935 parent resulting in a longer map of B.9. This may partially be explained by the fact that B.9 is the result of a cross within $M . \times$ domestica, whereas G.935 is the result of a series of interspecific crosses between M. $\times$ domestica, M. $\times$ robusta, and M. prunifolia. The use of the G935B9 map for trait analysis was checked by mapping the red leaf color trait heterozygous in the B.9 parent. Simple association analysis placed this trait in the same location as the

including physical location (chromosome and position in bps), mapped linkage group (LG), position in centi-Morgans (cM), segregation type, marker phase, and classification in JoinMap 4.1 format (Van Ooijen, 2011) are available in the Supplementary Tables. Although the great majority of mapped SNP markers mapped synchronously with the published 'Golden Delicious' physical map, 244 SNP (13.25\%) did not match with the physical map. In addition, a greater map length (increased number of recombinations) was observed in B.9 than G.935 probably because G.935 is a result of an interspecific cross. 


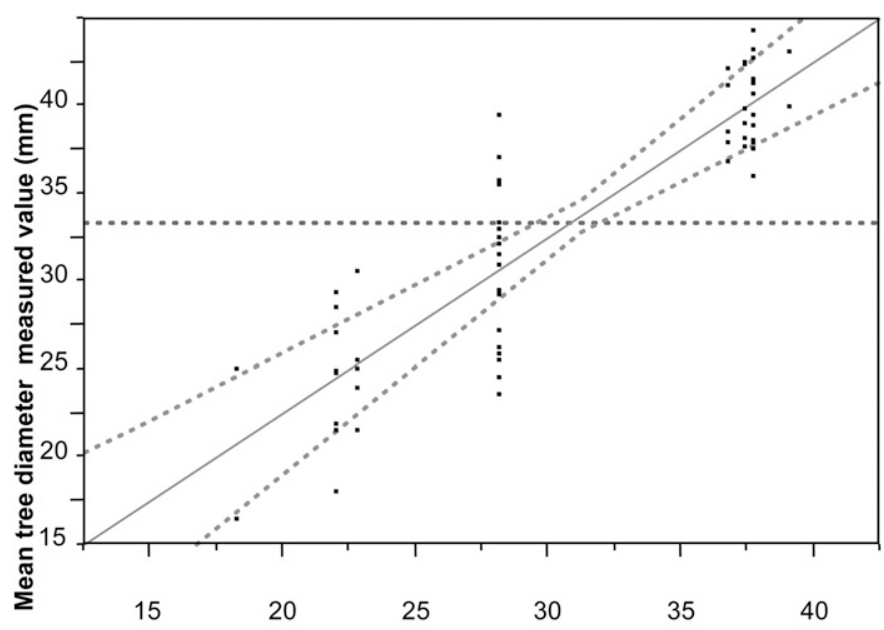

Mean tree diameter predicted value $(\mathrm{mm})$

Fig. 5. Regression model obtained for the interaction between $D w 1$ and $D w 2$ in the G935B9 finished apple tree progeny where the main effects (Dw1 and $D w 2)$ and their interaction $(D w 1 \times D w 2)$ were all statistically significant $(P<$ $\left.0.0001 ; R^{2}=0.80\right)$. Thanks to this model, it is therefore possible to predict with some certainty what dwarfing capacity each allelic combination may have. The model seems to be more predictive where either of the dwarfing loci are homozygous (the upper and lower parts of the curve) but less predictive where either or both loci are heterozygous.

Rni/MdMYB10 gene affecting apple anthocyanin production (Espley et al., 2006). These maps served the purpose of validating the effects and location of $D w 1$ and $D w 2$ in a different progeny and will continue to be a resource for understanding the genetic factors underlying more traits as more phenotypic measurements become available for clonally propagated seedlings of the same progeny.

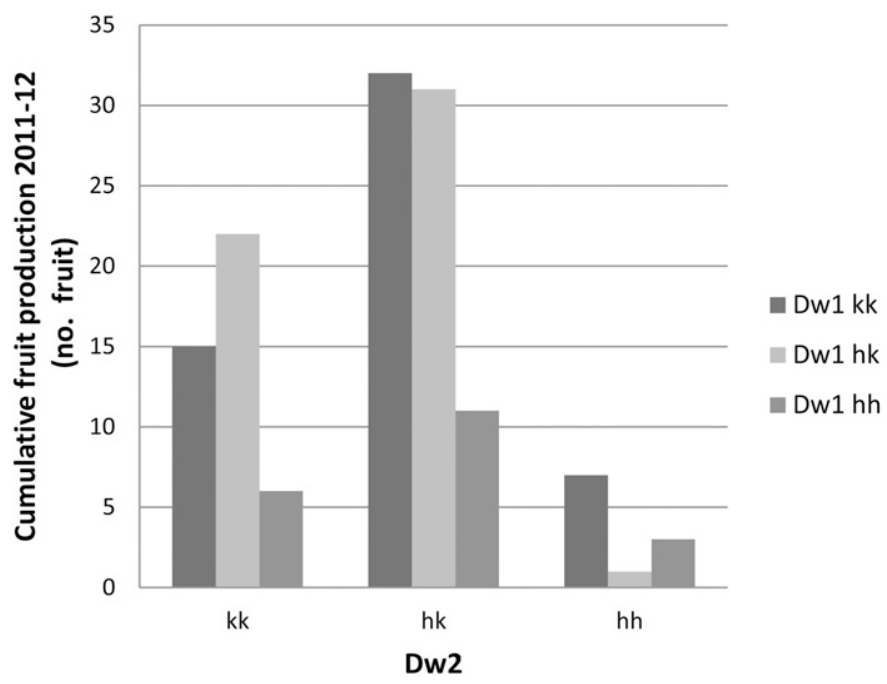

Fig. 6. Genotypic means display of cumulative fruit production of G935B9 apple trees of the interaction between $D w 1$ and $D w 2$ loci. The heterozygote rootstocks for $D w 2$ are the highest producers. With the exception of the $D w 1$ non-dwarfing homozygote rootstocks, the $D w 1$ allele constitution does not seem to affect the trends set by the $D w 2$ allele constitution. Codes hh, hk, and kk are the same as in the JoinMap (Van Ooijen, 2011) and MapQTL software (Kyazma, Wageningen, The Netherlands); they are assigned to alleles contributed by both heterozygous (hk) and represent allele constitution of progenies possible in this cross. Allele " $k$ " is dwarfing and allele " $h$ " is normal.
We have identified a second dwarfing locus (Dw2) in apple rootstocks and investigated the relationship of two dwarfing loci with early-bearing induction on scions. The effect of these loci was validated in additional breeding populations and we constructed new high-density maps for apple rootstock progenies. We have also used this new information to construct a predictive model based on the allelic constitution at the dwarfing loci. This model will aid in the breeding process by helping predict progeny performance and efficient crosses. These findings are being used to increase the efficiency of the breeding program and to develop a predictive marker-assisted breeding system for apple rootstocks.

\section{Literature Cited}

Aldwinckle, H.S. 1975. Flowering of apple seedlings 16-20 months after germination. HortScience 10:124-126.

Antanaviciute, L., F. Fernández-Fernández, J. Jansen, E. Banchi, K.M. Evans, R. Viola, R. Velasco, J.M. Dunwell, M. Troggio, and D.J. Sargent. 2012. Development of a dense SNP-based linkage map of an apple rootstock progeny using the Malus Infinium whole genome genotyping array. BMC Genomics 13:203.

Atkinson, C.J., M.A. Else, L. Taylor, and C.J. Dover. 2003. Root and stem hydraulic conductivity as determinants of growth potential in grafted trees of apple (Malus pumila Mill.). J. Expt. Bot. 54:12211229.

Autio, W., T.L. Robinson, J. Cline, R.M. Crassweller, C.G. Embree, E. Hoover, G. Lang, J. Masabni, M.L. Parker, R. Perry, G.L. Reighard, and M. Warmund. 2011a. Performance of several semidwarfing rootstocks with 'Fuji' and 'McIntosh' as scion cultivars in the 1999 NC-140 semi-dwarf apple rootstock trials. Acta Hort. 903:327-334.

Autio, W., T.L. Robinson, W. Cowgill, C. Hampson, M. Kushad, G. Lang, J. Masabni, D.D. Miller, R.A. Parra-Quezada, R. Perry, and C. Rom. 2011b. Performance of 'Gala' apple trees on supporter 4 and different strains of 'B.9', 'M.9', and 'M.26' rootstocks as part of the 2002 NC-140 apple rootstock trial. Acta Hort. 903:311-318.

Auvil, T.D., T.R. Schmidt, I. Hanrahan, F. Castillo, J.R. McFerson, and G. Fazio. 2011. Evaluation of dwarfing rootstocks in Washington apple replant sites. Acta Hort. 903:265-271.

Barron, A.F. 1889. Experiments in grafting apples at Chiswick, 187584. J. Royal Hort. Soc. 11:13-15.

Budagovskii, V.I. 1940. Marga hndzôr, a dwarf apple. Plodovye i Yagodnye Kul'tury 3:19-23 (abstract).

Carlson, R.F. and S.D. Oh. 1975. Influence of interstem lengths of 'M.8' clone Malus sylvestris Mill. on growth, precocity, yield, and spacing of 2 apple cultivars. J. Amer. Soc. Hort. Sci. 100:450-452.

Celton, J.M., D.S. Tustin, D. Chagné, and S.E. Gardiner. 2009. Construction of a dense genetic linkage map for apple rootstocks using SSRs developed from Malus ESTs and Pyrus genomic sequences. Tree Genet. Genomes 5:93-107.

Chagné, D., R.N. Crowhurst, M. Troggio, M.W. Davey, B. Gilmore, C. Lawley, S. Vanderzande, R.P. Hellens, S. Kumar, A. Cestaro, R. Velasco, D. Main, J.D. Rees, A. Iezzoni, T. Mockler, L. Wilhelm, E. Van de Weg, S.E. Gardiner, N. Bassil, and C. Peace. 2012. Genome-wide SNP detection, validation, and development of an $8 \mathrm{~K}$ SNP array for apple. PLoS One 7:e31475.

Cohen, S., A. Naor, J. Bennink, A. Grava, and M. Tyree. 2007. Hydraulic resistance components of mature apple trees on rootstocks of different vigours. J. Expt. Bot. 58:4213-4224.

Conner, P.J., S.K. Brown, and N.F. Weeden. 1998. Molecular-marker analysis of quantitative traits for growth and development in juvenile apple trees. Theor. Appl. Genet. 96:1027-1035.

Cummins, J.N. and H.S. Aldwinckle. 1974. Breeding apple rootstocks. HortScience 9:367-372.

Cummins, J.N., H.S. Aldwinckle, and J. Janick. 1983. Breeding apple rootstocks. Plant Breed. Rev. 1:294-394. 
Dirlewanger, E., E. Graziano, T. Joobeur, F. Garriga-Calderé, P. Cosson, W. Howad, and P. Arús. 2004. Comparative mapping and marker-assisted selection in Rosaceae fruit crops. Proc. Natl. Acad. Sci. USA 101:9891-9896.

Espley, R.V., R.P. Hellens, J. Putterill, D.E. Stevenson, S. KuttyAmma, and A.C. Allan. 2006. Red colouration in apple fruit is due to the activity of the MYB transcription factor, MdMYB10. Plant J. 49:414-427.

Fallahi, E., B. Fallahi, B. Shafii, and J.R. McFerson. 2011. The impact of rootstock and irrigation on water use, tree growth, nutrition, yield, and fruit quality of 'Pacific Gala' apple. Acta Hort. 903:915-921.

Fazio, G., H.S. Aldwinckle, T.L. Robinson, and Y. Wan. 2011. Implementation of molecular marker technologies in the apple rootstock breeding program in Geneva-Challenges and successes. Acta Hort. 903:61-68.

Fazio, G., D. Kviklys, M.A. Grusak, and T.L. Robinson. 2013. Phenotypic diversity and QTL mapping of absorption and translocation of nutrients by apple rootstocks. Asp. Appl. Biol. 119:3750 .

Fazio, G., D. Kviklys, M.A. Grusak, and T.L. Robinson. 2012a. Elucidating the genetics of absorption and translocation of macroand micronutrients by apple rootstocks in the context of breeding populations. HortScience 47:S101-S102 (abstract).

Fazio, G., D. Kviklys, M.A. Grusak, and T.L. Robinson. 2012b. Soil $\mathrm{pH}$, soil type and replant disease affect growth and nutrient absorption in apple rootstocks. NewYork Fruit Qrtly. 20:22-28.

Fazio, G., D. Kviklys, and T. Robinson. 2009. QTL mapping of root architectural traits in apple rootstocks. HortScience 44:986-987 (abstract).

Fazio, G. and M. Mazzola. 2004. Target traits for the development of marker assisted selection of apple rootstocks-Prospects and benefits. Acta Hort. 663:823-827.

Fazio, G. and T.L. Robinson. 2008. Modification of nursery tree architecture by apple rootstocks. HortScience 43:1271 (abstract).

Fischer, M. 1974. Present position and trends in the breeding of apple rootstock. Neue Deutsche Obstbau 20:9-10 (abstract).

Gardiner, S., J. Norelli, N. de Silva, G. Fazio, A. Peil, M. Malnoy, M. Horner, D. Bowatte, C. Carlisle, C. Wiedow, Y. Wan, C. Bassett, A. Baldo, J. Celton, K. Richter, H. Aldwinckle, and V. Bus. 2012. Putative resistance gene markers associated with quantitative trait loci for fire blight resistance in Malus 'Robusta 5' accessions. BMC Genet. 13:25.

Gharghani, A., Z. Zamani, A. Talaie, N.C. Oraguzie, R. Fatahi, H. Hajnajari, C. Wiedow, and S.E. Gardiner. 2009. Genetic identity and relationships of Iranian apple (Malus $\times$ domestica Borkh.) cultivars and landraces, wild Malus species and representative old apple cultivars based on simple sequence repeat (SSR) marker analysis. Genet. Resources Crop Evol. 56:829-842.

Hatton, R.G. 1917. 'Paradise' apple stocks. J. Royal Hort. Soc. 42:361399.

Hatton, R.G. 1919. 'Paradise' apple stocks their fruit and blossom described. J. Royal Hort. Soc. 44:89-94.

Hemmat, M., N.F. Weeden, P.J. Conner, and S.K. Brown. 1997. A DNA marker for columnar growth habit in apple contains a simple sequence repeat. J. Amer. Soc. Hort. Sci. 122:347-349.

Iezzoni, A. 2010. RosBREED: Enabling marker-assisted breeding in the Rosaceae. HortScience 45:S27-S28 (abstract).

Jensen, P.J., N. Halbrendt, G. Fazio, I. Makalowska, N. Altman, C. Praul, S.N. Maximova, H.K. Ngugi, R.M. Crassweller, J.W. Travis, and T.W. McNellis. 2012. Rootstock-regulated gene expression patterns associated with fire blight resistance in apple. BMC Genomics 13:9.

Jensen, P.J., I. Makalowska, N. Altman, G. Fazio, C. Praul, S.N. Maximova, R.M. Crassweller, J.W. Travis, and T.W. McNellis. 2010. Rootstock-regulated gene expression patterns in apple tree scions. Tree Genet. Genomes 6:57-72.

Johnson, W.C., H.S. Aldwinckle, J.N. Cummins, P.L. Forsline, H.T. Holleran, J.L. Norelli, T.L. Robinson, J.W. Palmer, and J.N.
Wunsche. 2001. The new USDA-ARS/Cornell University apple rootstock breeding and evaluation program. Acta Hort. 557:3540.

Kamboj, J.S., P.S. Blake, J.D. Quinlan, and D.A. Baker. 1999. Identification and quantitation by GC-MS of zeatin and zeatin riboside in xylem sap from rootstock and scion of grafted apple trees. Plant Growth Regulat. 28:199-205.

Kamboj, J.S., J.D. Quinlan, J.L. Guardiola, and J.L. Garcia Martinez. 1998. The apple rootstock and its influence on endogenous hormones. Acta Hort. 463:143-152.

Kenis, K. and J. Keulemans. 2007. Study of tree architecture of apple (Malus $\times$ domestica Borkh.) by QTL analysis of growth traits. Mol. Breed. 19:193-208.

Khan, M.A., Y.P. Han, Y.F. Zhao, M. Troggio, and S.S. Korban. 2012. A multi-population consensus genetic map reveals inconsistent marker order among maps likely attributed to structural variations in the apple genome. PLoS One 7:e47864.

Koike, H. and K. Tsukahara. 1988. Various interstem effects in combination with 'Marubakaido N-1' rootstock on 'Fuji' apple growth. HortScience 23:580-581.

Lauri, P.E., K. Maguylo, and C. Trottier. 2006. Architecture and size relations: An essay on the apple (Malus $\times$ domestica, Rosaceae) tree. Amer. J. Bot. 93:357-368.

Leinfelder, M.M. and I.A. Merwin. 2006. Rootstock selection, preplant soil treatments, and tree planting positions as factors in managing apple replant disease. HortScience 41:394-401.

Liebhard, R., L. Gianfranceschi, B. Koller, C.D. Ryder, R. Tarchini, E.d. Weg, and C. Gessler. 2002. Development and characterization of 140 new microsatellites in apple (Malus $\times$ domestica Borkh.). Mol. Breed. 10:217-241.

Lindley, J. 1828. The pomological magazine; or, figures and descriptions of the most important varieties of fruit cultivated in Great Britain. 4 Dec. 2013. <https://archive.org/details/pomologicalmagaz02lind $>$.

Loudon, J.C. 1822. An encyclopaedia of gardening. 4 Dec. 2013. $<$ http://catalog.hathitrust.org/Record/009727252>.

Marini, R.P., R. Moran, C. Hampson, M. Kushad, R.L. Perry, and T.L. Robinson. 2008. Effect of dwarf apple rootstocks on average 'Gala' fruit weight at six locations over three seasons. J. Amer. Pomol. Soc. 62:129-136.

Mazzola, M. 1998. Elucidation of the microbial complex having a causal role in the development of apple replant disease in Washington. Phytopathology 88:930-938.

Monceau, D.d. 1768. Traiteì des arbres fruitiers: Contenant leur figure, leur description, leur culture. 4 Dec. 2013. <http://www. biodiversitylibrary.org/bibliography/16026\#/summary>.

Moriya, S., H. Iwanami, N. Kotoda, T. Haji, K. Okada, S. Terakami, N. Mimida, T. Yamamoto, and K. Abe. 2012. Aligned genetic linkage maps of apple rootstock cultivar 'JM7' and Malus sieboldii 'Sanashi 63' constructed with novel EST-SSRs. Tree Genet. Genomes 8:709723.

Oraguzie, N.C., T. Yamamoto, J. Soejima, T. Suzuki, and H.N.d. Silva. 2005. DNA fingerprinting of apple (Malus spp.) rootstocks using simple sequence repeats. Plant Breed. 124:197-202.

Patocchi, A., M. Walser, S. Tartarini, G.A.L. Broggini, F. Gennari, S. Sansavini, and C. Gessler. 2005. Identification by genome scanning approach (GSA) of a microsatellite tightly associated with the apple scab resistance gene Vm. Genome 48:630-636.

Pilcher, R.L.R., J.M. Celton, S.E. Gardiner, and D.S. Tustin. 2008. Genetic markers linked to the dwarfing trait of apple rootstock 'Malling 9'. J. Amer. Soc. Hort. Sci. 133:100-106.

Quamme, H.A. and R.T. Brownlee. 1990. Stool layering ability of thirty-one apple rootstock cultivars. Fruit Var. J. 44:165-169.

Rivers, T. 1866. The miniature fruit garden; or, the culture of pyramidal and bush fruit trees. 4 Dec. 2013. <http://archive.org/ stream/miniaturefruitga01rive/miniaturefruitga01rive_djvu.txt $>$.

Robinson, T.L., S.A. Hoying, and G. Fazio. 2011a. Performance of Geneva rootstocks in on-farm trials in New York State. Acta Hort. 903:249-255. 
Robinson, T.L., S.A. Hoying, and G.H. Reginato. 2011b. The tall spindle planting system: Principles and performance. Acta Hort. 903:571-579. Russo, N.L., T.L. Robinson, G. Fazio, and H.S. Aldwinckle. 2007. Field evaluation of 64 apple rootstocks for orchard performance and fire blight resistance. HortScience 42:1517-1525.

Segura, V., C.E. Durel, and E. Costes. 2009. Dissecting apple tree architecture into genetic, ontogenetic and environmental effects: QTL mapping. Tree Genet. Genomes 5:165-179.

Seleznyova, A.N., T.G. Thorp, M. White, S. Tustin, and E. Costes. 2003. Application of architectural analysis and AMAPmod methodology to study dwarfing phenomenon: The branch structure of 'Royal Gala' apple grafted on dwarfing and non-dwarfing rootstock/interstock combinations. Ann. Bot. (Lond.) 91:665-672.

Seleznyova, A.N., D.S. Tustin, and T.G. Thorp. 2008. Apple dwarfing rootstocks and interstocks affect the type of growth units produced during the annual growth cycle: Precocious transition to flowering affects the composition and vigour of annual shoots. Ann. Bot. (Lond.) 101:679-687.

Silfverberg-Dilworth, E., C.L. Matasci, W.E. Van de Weg, M.P.W. Van Kaauwen, M. Walser, L.P. Kodde, V. Soglio, L. Gianfranceschi, C.E. Durel, F. Costa, T. Yamamoto, B. Koller, C. Gessler, and A. Patocchi. 2006. Microsatellite markers spanning the apple (Malus $\times$ domestica Borkh.) genome. Tree Genet. Genomes 2:202-224.

Soumelidou, K., N.H. Battey, P. John, and J.R. Barnett. 1994a. The anatomy of the developing bud union and its relationship to dwarfing in apple. Ann. Bot. (Lond.) 74:605-611.

Soumelidou, K., D.A. Morris, N.H. Battey, J.R. Barnett, and P. John. 1994b. Auxin transport capacity in relation to the dwarfing effect of apple rootstocks. J. Hort. Sci. 69:719-725.

Spangelo, L.P.S., S.O. Fejer, S.J. Leuty, and R.L. Granger. 1974. 'Ottawa 3' clonal apple rootstock. Can. J. Plant Sci. 54:601-603.

Tworkoski, T. and G. Fazio. 2011. Physiological and morphological effects of size-controlling rootstocks on 'Fuji' apple scions. Acta Hort. 903:865-872.

Tworkoski, T. and S. Miller. 2007. Rootstock effect on growth of apple scions with different growth habits. Sci. Hort. 111:335-343.

van Hooijdonk, B., D. Woolley, I. Warrington, and S. Tustin. 2011. Rootstocks modify scion architecture, endogenous hormones, and root growth of newly grafted 'Royal Gala' apple trees. J. Amer. Soc. Hort. Sci. 136:93-102.

van Hooijdonk, B.M., D.J. Woolley, I.J. Warrington, and D.S. Tustin. 2010. Initial alteration of scion architecture by dwarfing apple rootstocks may involve shoot-root-shoot signalling by auxin, gibberellin, and cytokinin. J. Hort. Sci. Biotechnol. 85:59-65.
Van Ooijen, J.W. 2011. Multipoint maximum likelihood mapping in a full-sib family of an outbreeding species. Genet. Res. 93:343-349. Velasco, R., A. Zharkikh, J. Affourtit, A. Dhingra, A. Cestaro, A. Kalyanaraman, P. Fontana, S.K. Bhatnagar, M. Troggio, D. Pruss, S. Salvi, M. Pindo, P. Baldi, S. Castelletti, M. Cavaiuolo, G. Coppola, F. Costa, V. Cova, A. Dal Ri, V. Goremykin, M. Komjanc, S. Longhi, P. Magnago, G. Malacarne, M. Malnoy, D. Micheletti, M. Moretto, M. Perazzolli, A. Si-Ammour, S. Vezzulli, E. Zini, G. Eldredge, L.M. Fitzgerald, N. Gutin, J. Lanchbury, T. Macalma, J.T. Mitchell, J. Reid, B. Wardell, C. Kodira, Z. Chen, B. Desany, F. Niazi, M. Palmer, T. Koepke, D. Jiwan, S. Schaeffer, V. Krishnan, C. Wu, V.T. Chu, S.T. King, J. Vick, Q. Tao, A. Mraz, A. Stormo, K. Stormo, R. Bogden, D. Ederle, A. Stella, A. Vecchietti, M.M. Kater, S. Masiero, P. Lasserre, Y. Lespinasse, A.C. Allan, V. Bus, D. Chagne, R.N. Crowhurst, A.P. Gleave, E. Lavezzo, J.A. Fawcett, S. Proost, P. Rouze, L. Sterck, S. Toppo, B. Lazzari, R.P. Hellens, C.E. Durel, A. Gutin, R.E. Bumgarner, S.E. Gardiner, M. Skolnick, M. Egholm, Y. Van de Peer, F. Salamini, and R. Viola. 2010. The genome of the domesticated apple (Malus $\times$ domestica Borkh.). Nat. Genet. 42:833-839.

Volz, R.K., E. Rikkerink, P. Austin, T. Lawrence, and V.G.M. Bus. 2009. 'Fast-breeding' in apple: A strategy to accelerate introgression of new traits into elite germplasm. Acta Hort. 814:163-168.

Wan, Y. and G. Fazio. 2011. Confirmation by QTL mapping of the Malus robusta ('Robusta 5') derived powdery mildew resistance gene P11. Acta Hort. 903:95-99.

Wang, A.D., H. Aldwinckle, P. Forsline, D. Main, G. Fazio, S. Brown, and K.N. Xu. 2012. EST contig-based SSR linkage maps for Malus $\times$ domestica cv Royal Gala and an apple scab resistant accession of M. sieversii, the progenitor species of domestic apple. Mol. Breed. 29:379-397.

Watkins, R., A.G. Brown, and F. Alston. 1973. Rootstock breeding at East Malling. Proc. Eucarpia Fruit Section Symp. 5:145-153.

Webster, A.D. and I.J. Warrington. 1995. Rootstock and interstock effects on deciduous fruit tree vigour, precocity, and yield productivity. N. Z. J. Crop Hort. Sci. 23:373-382.

Webster, T., K. Tobutt, and K. Evans. 2000. Breeding and evaluation of new rootstocks for apple, pear and sweet cherry. Compact Fruit Tree 33:100-104.

Wertheim, S.J. 1998. Rootstock guide: Apple, pear, cherry, european plum. Proefstation voor de Fruitteelt, Wilhelminadorp, The Netherlands.

Zimmerman, R.H. 1972. Juvenility and flowering in woody plants: A review. HortScience 7:447-455. 


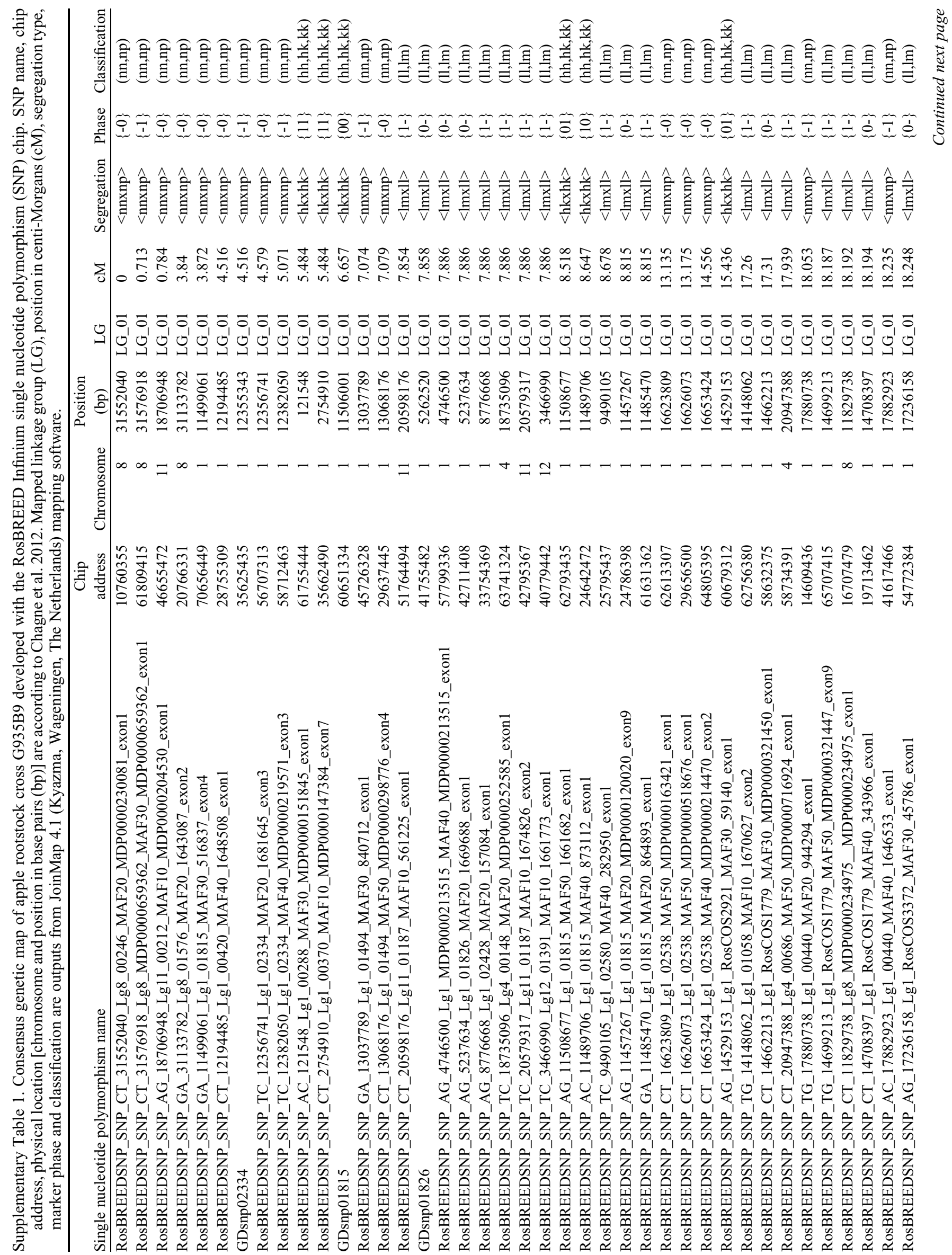




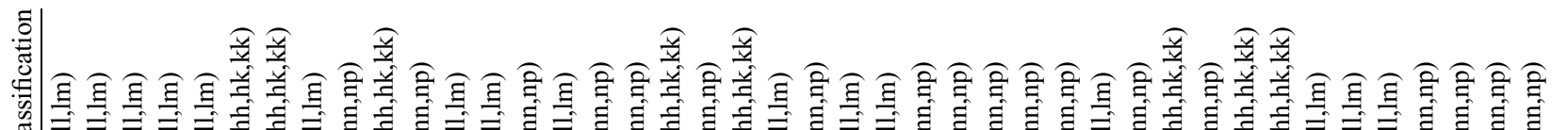

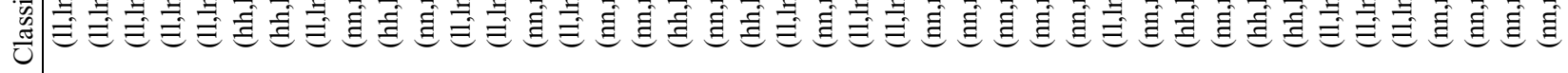

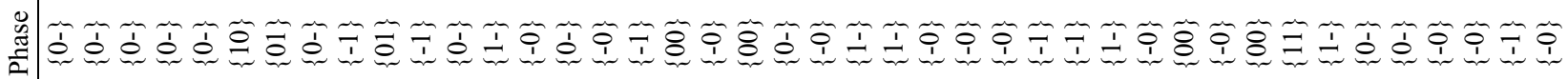

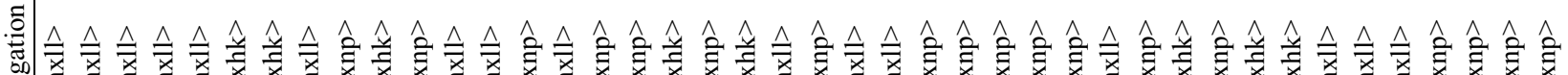

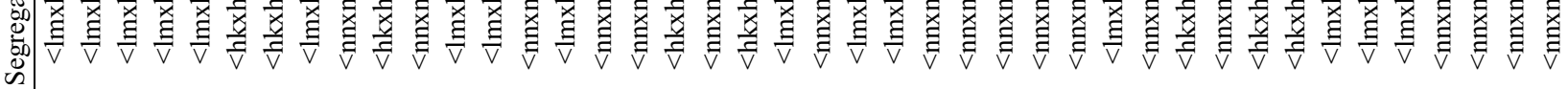

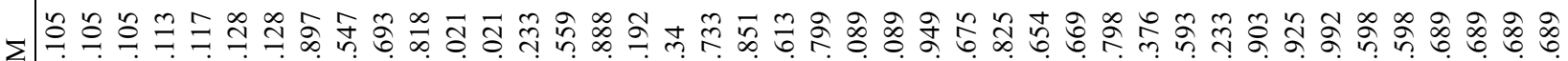

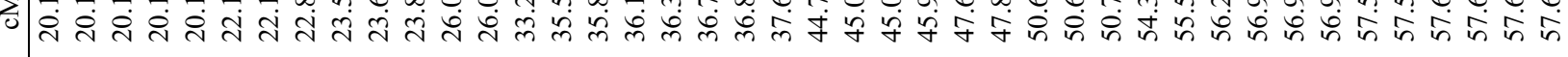

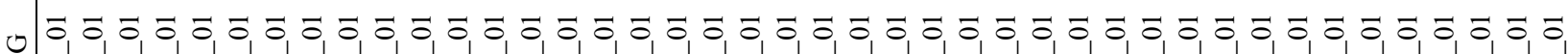

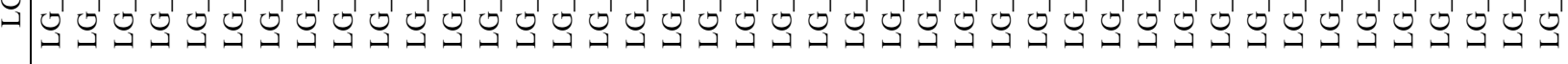

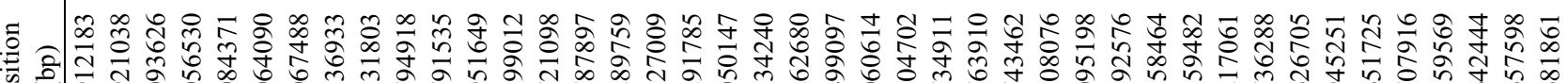
政

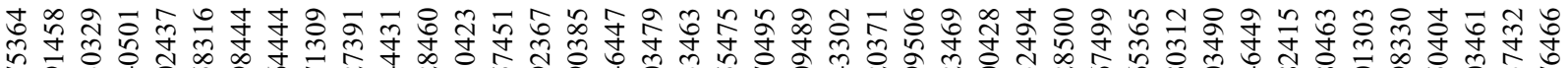

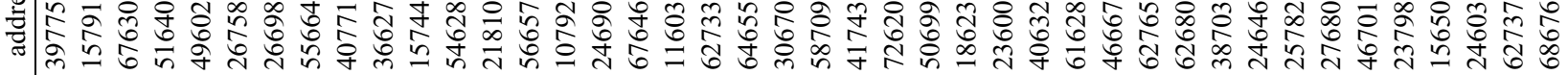

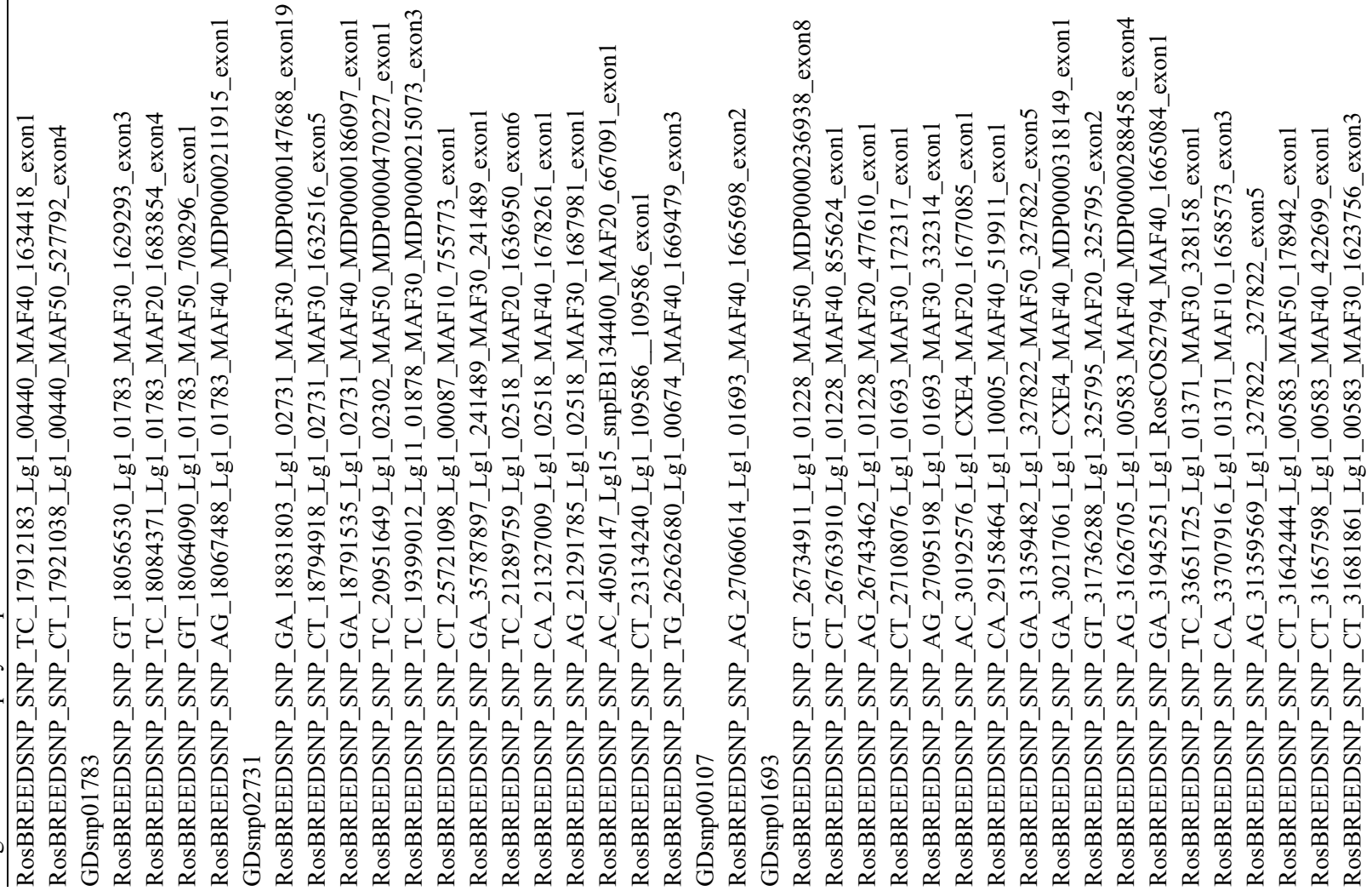




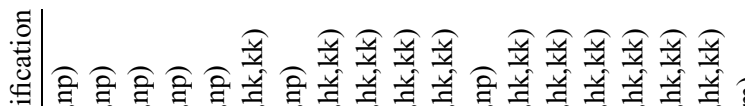

离离

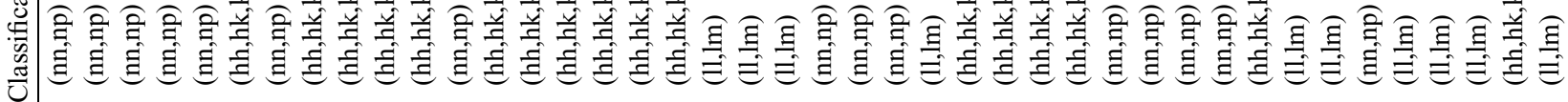

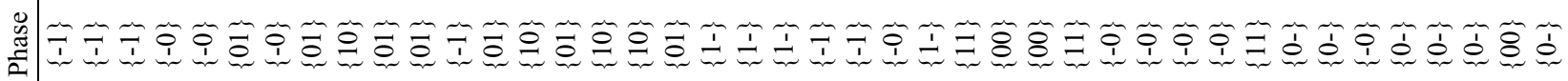

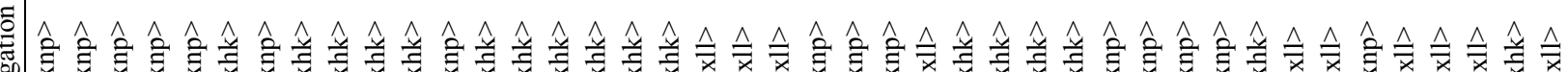

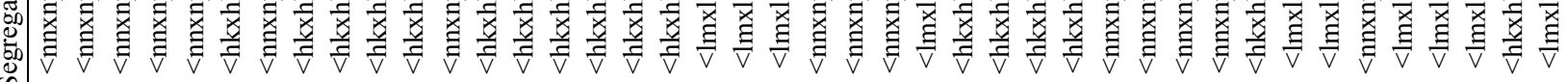
๗

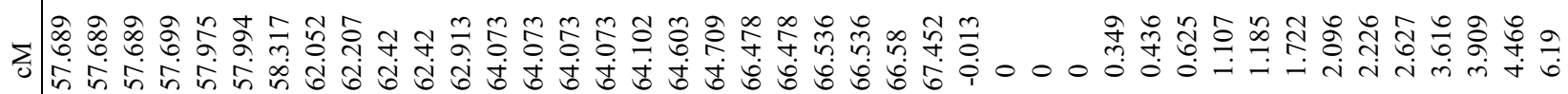

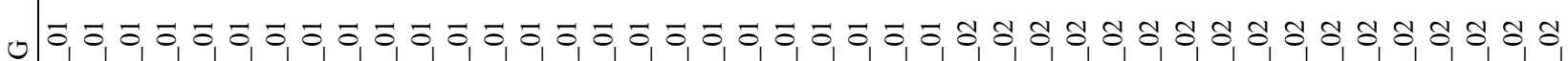

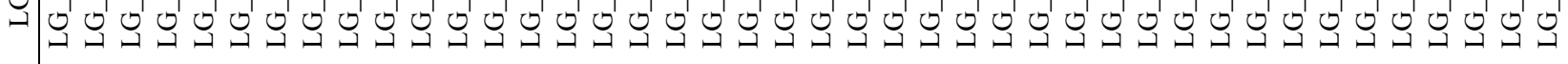

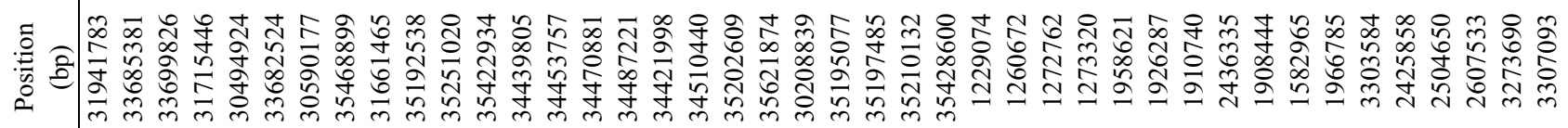

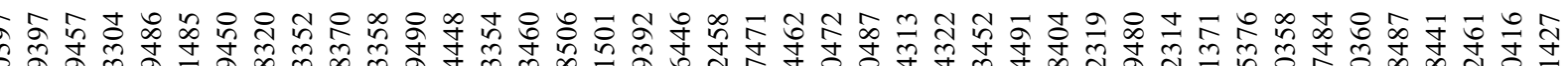

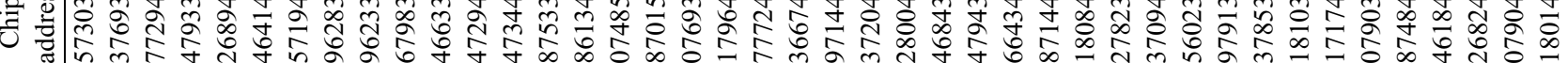

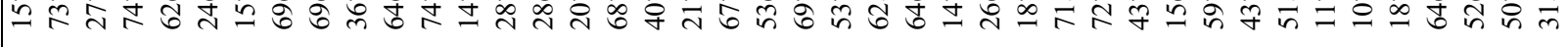

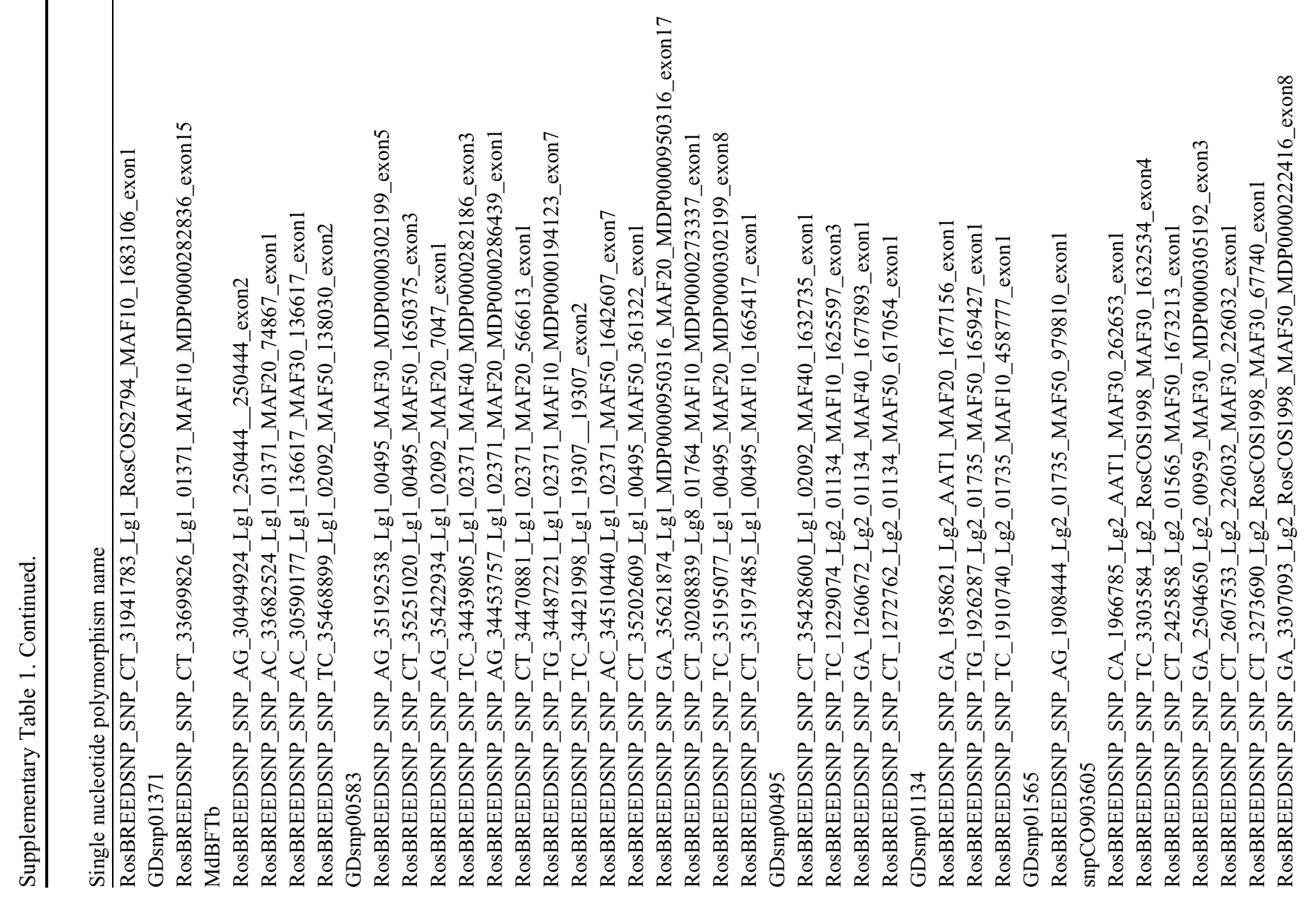




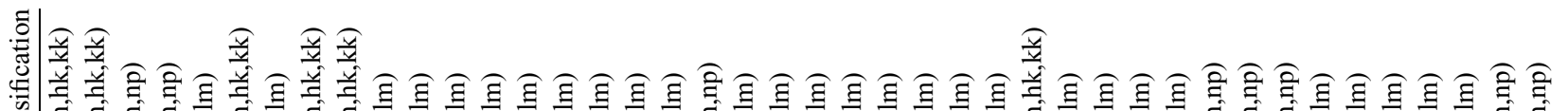

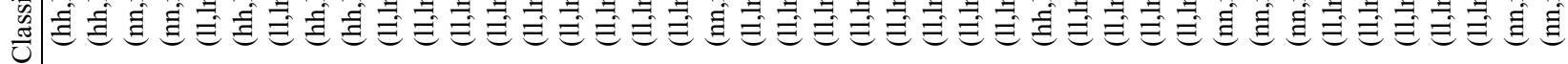

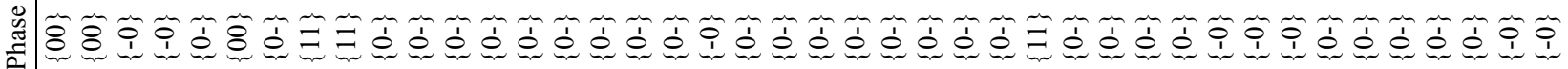

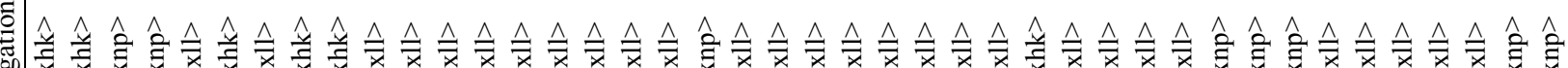

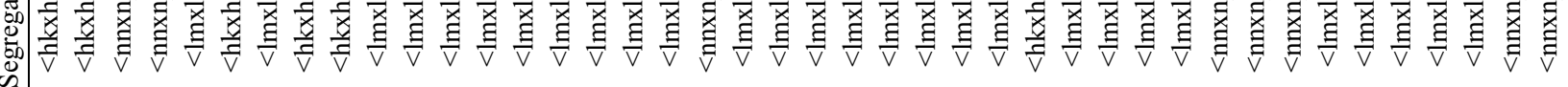

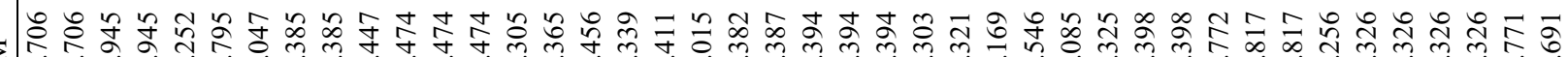

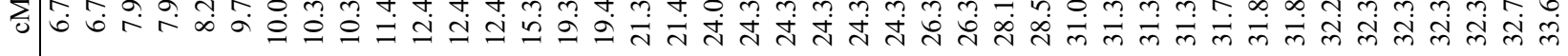

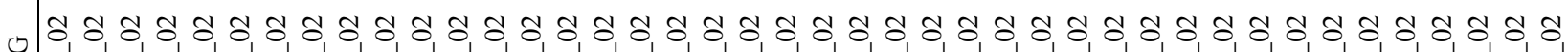

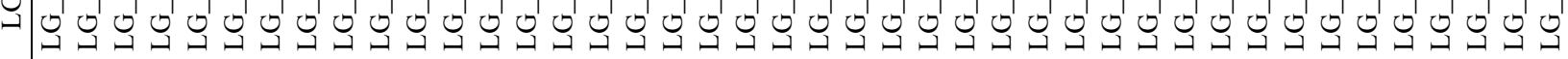

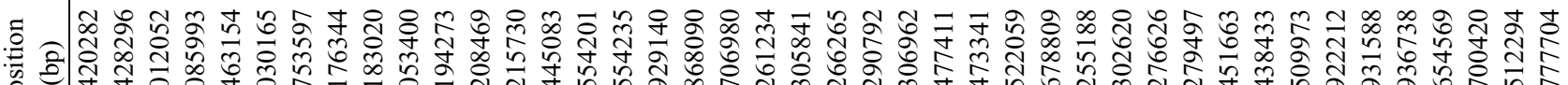

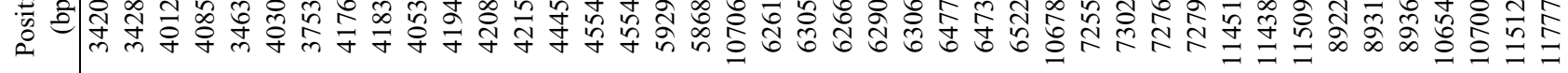
离

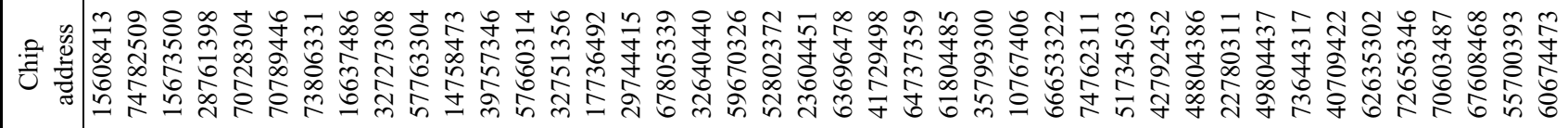

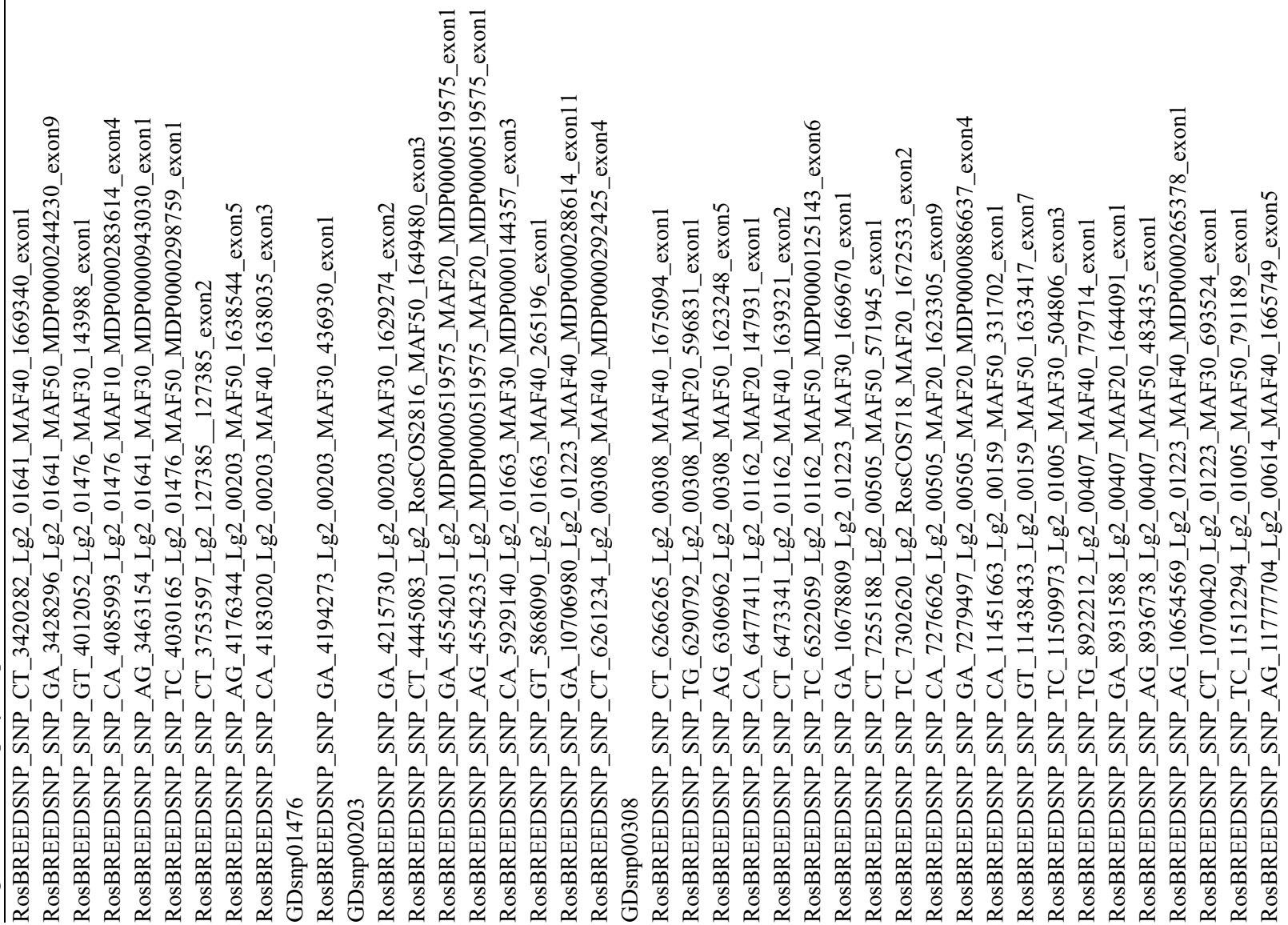




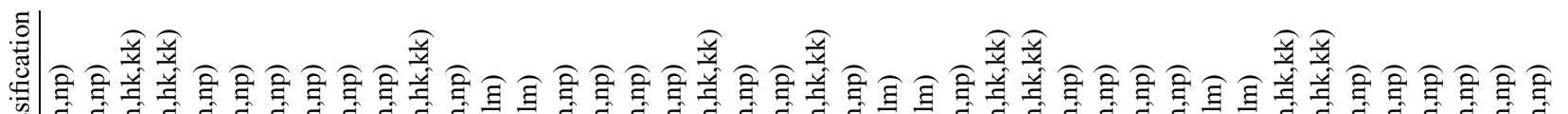

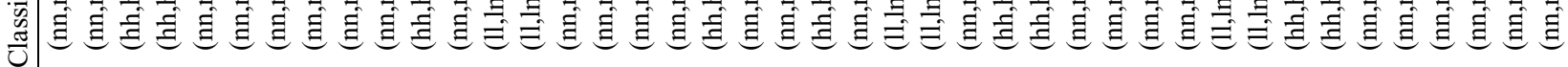

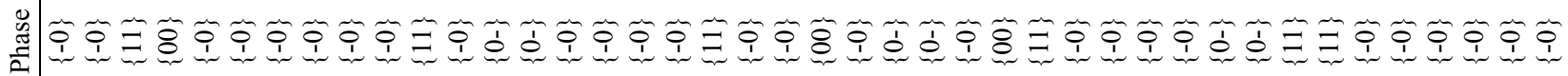

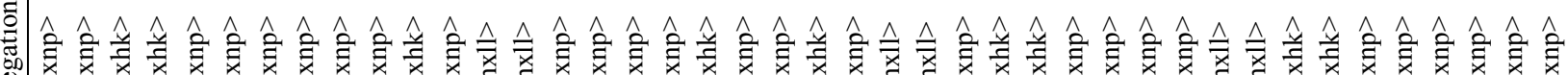

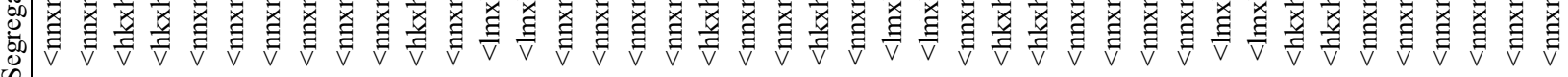

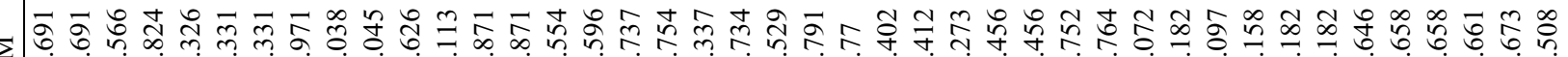

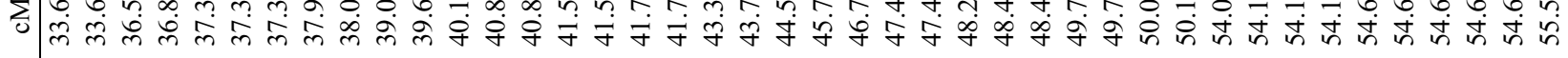

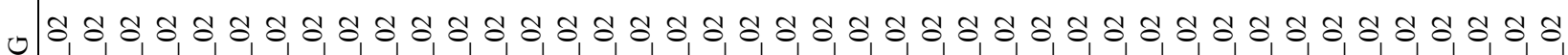

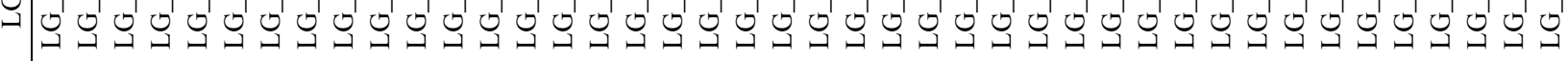

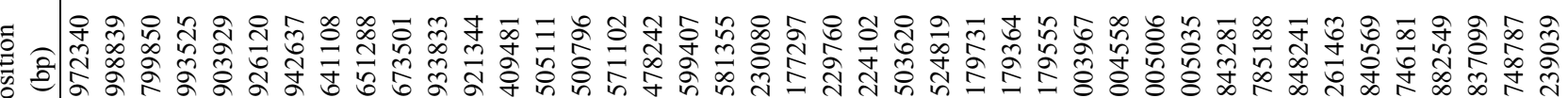

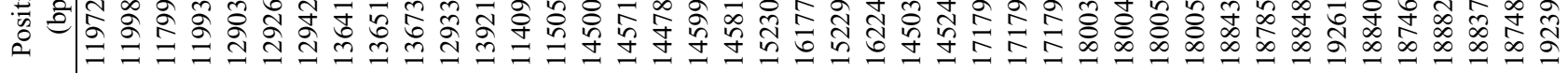
竞

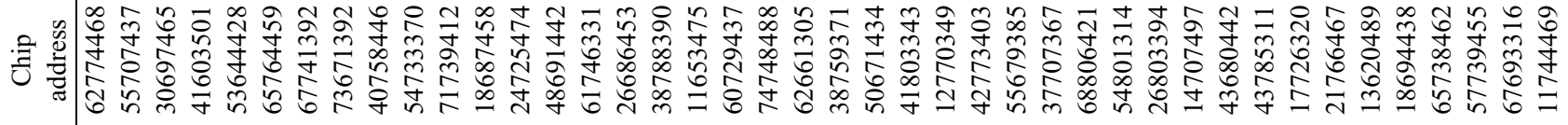

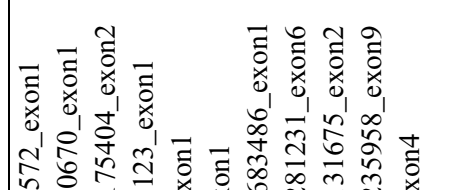

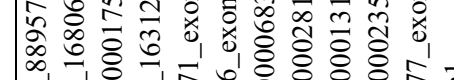

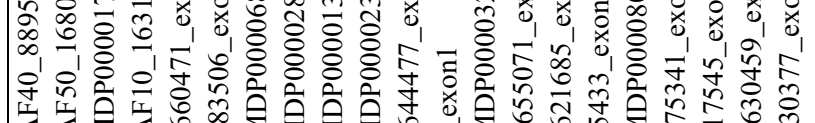

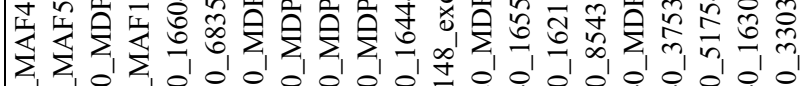

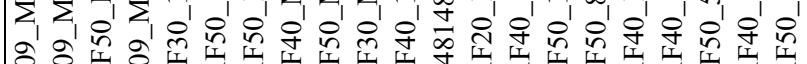

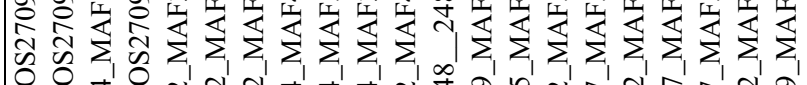

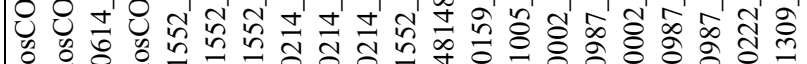
$\approx$

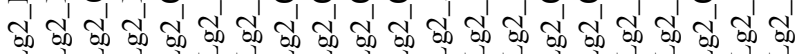

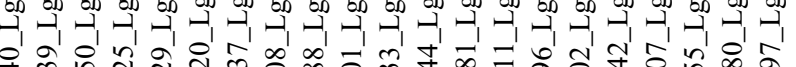

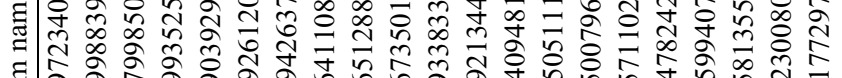

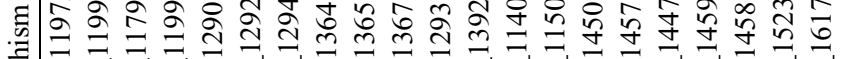

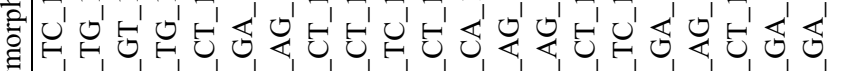

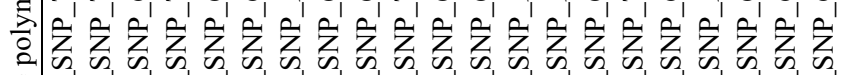

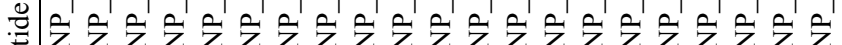

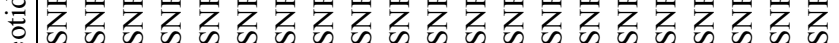

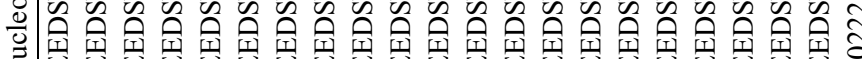

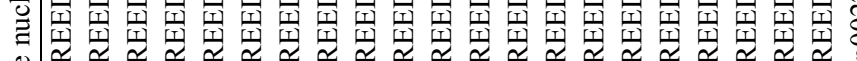

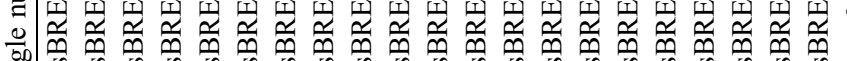

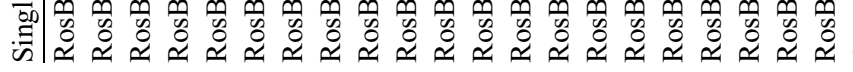




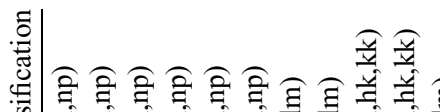

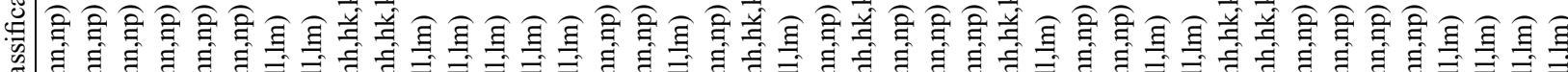

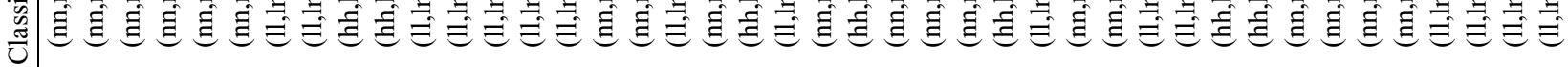

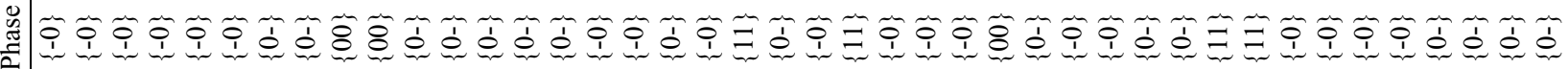

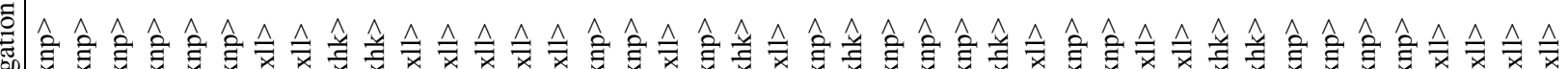

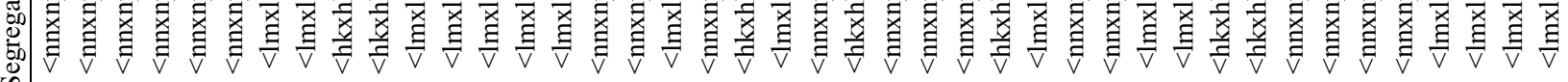
ڤ

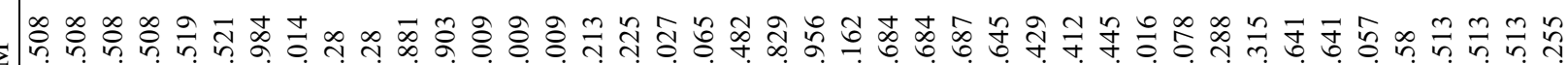

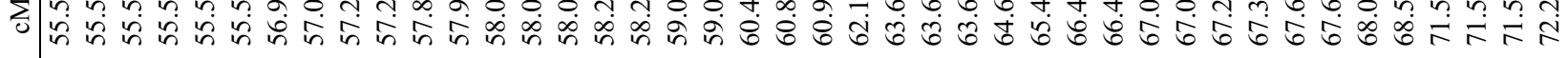

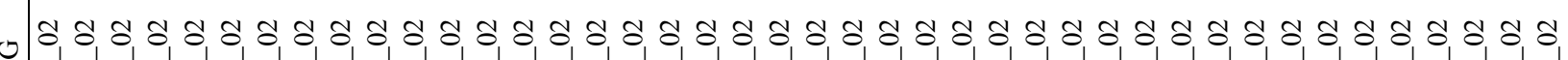

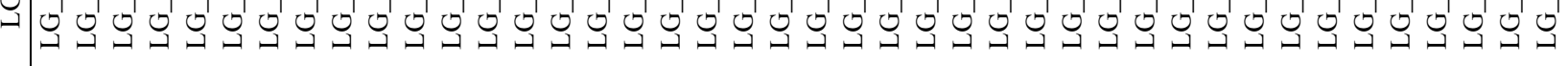

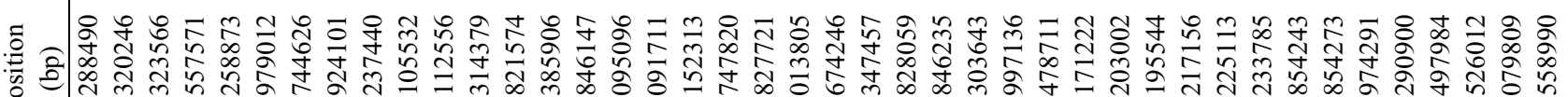

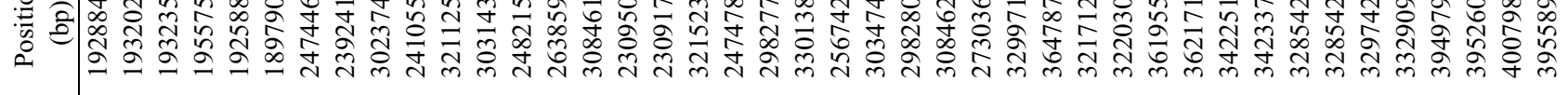

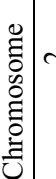

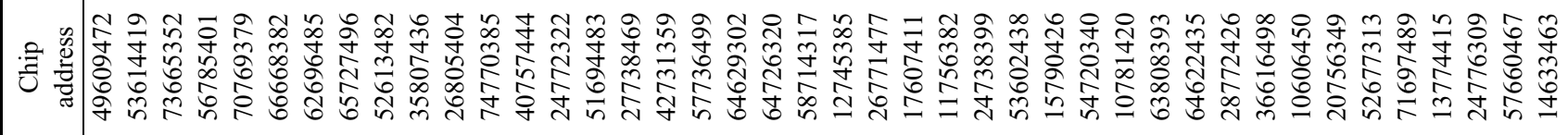

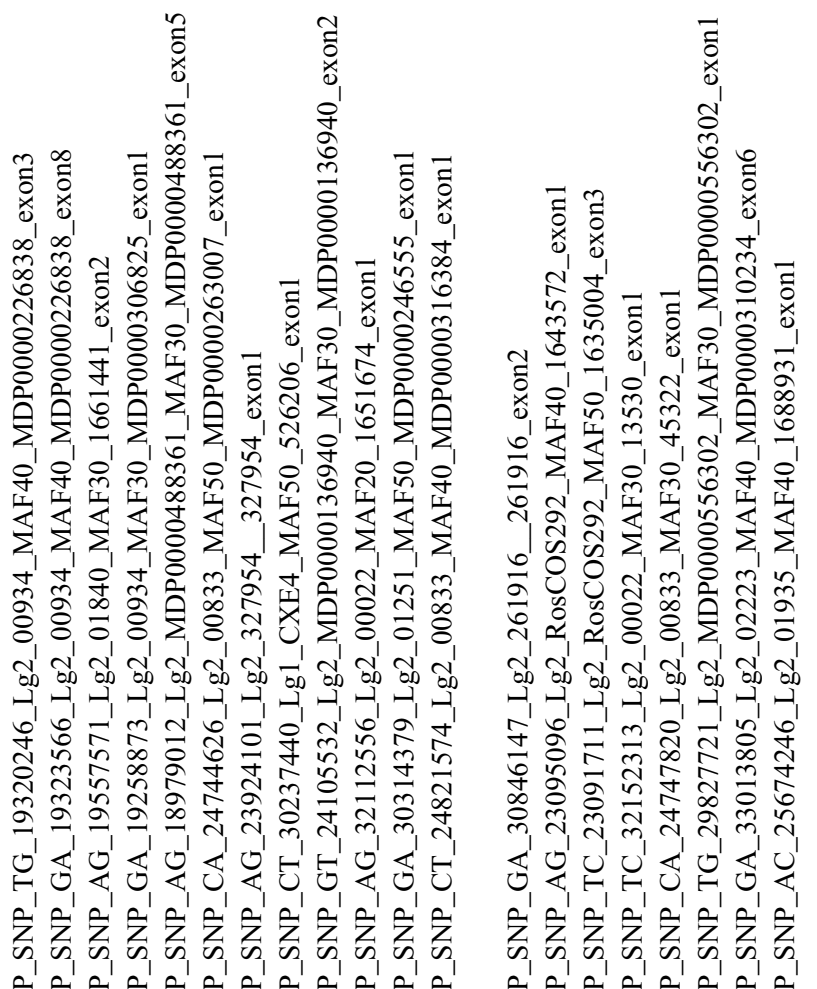

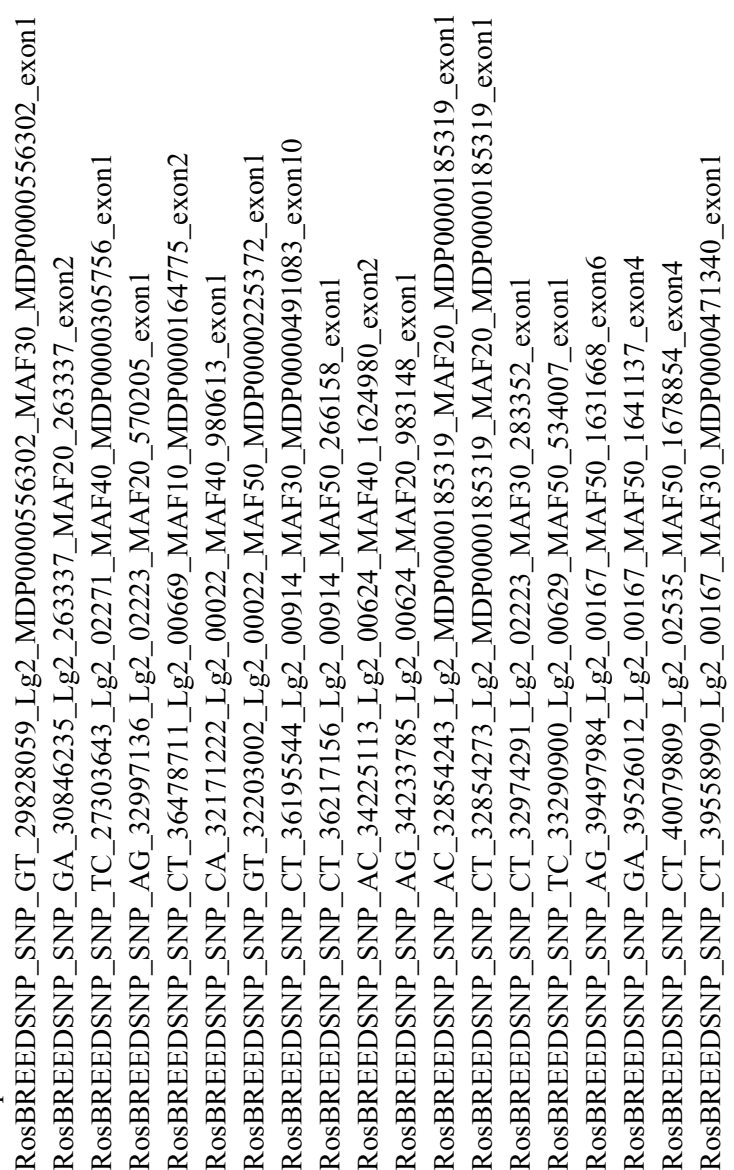




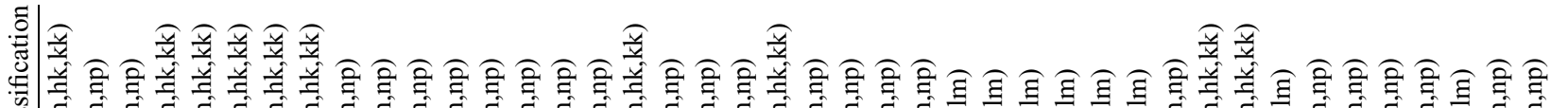

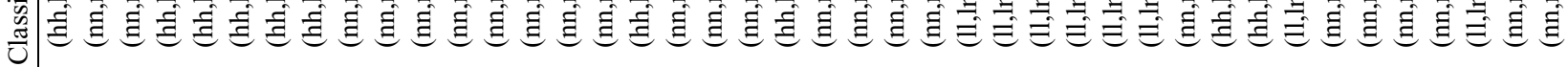

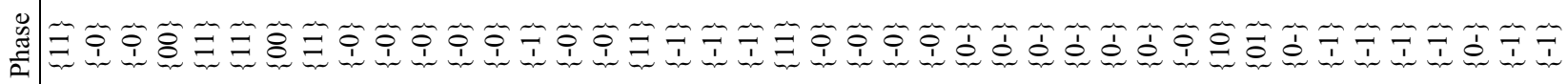

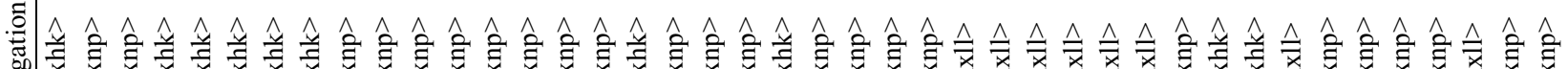

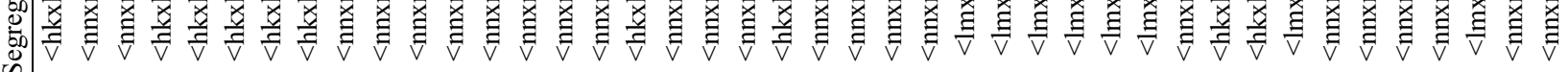

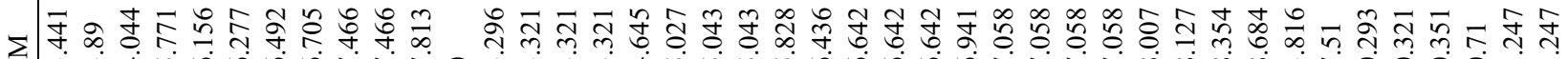

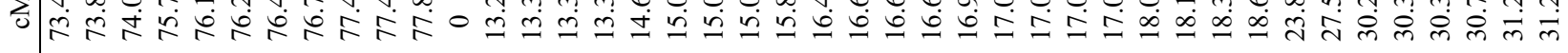

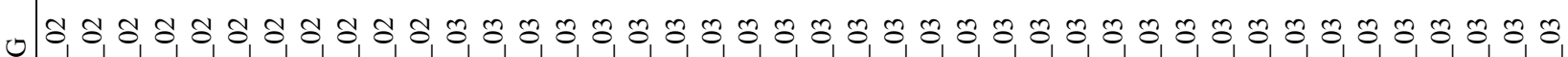

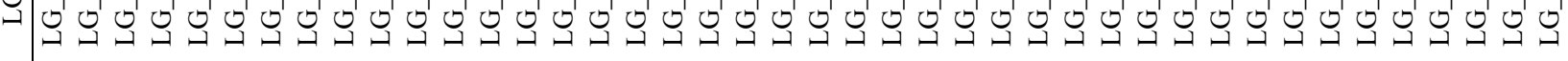

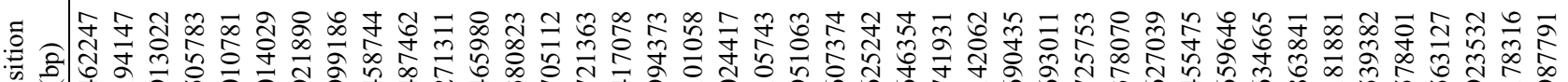

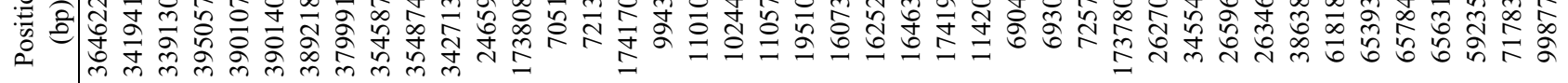
竞

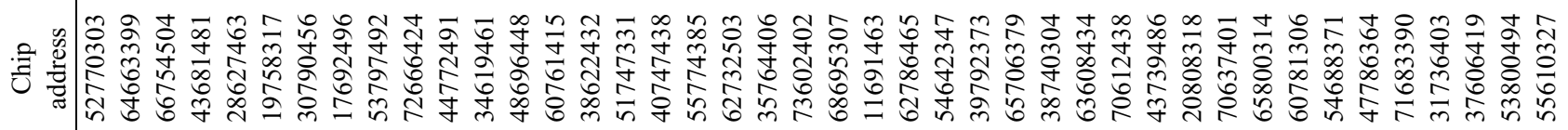

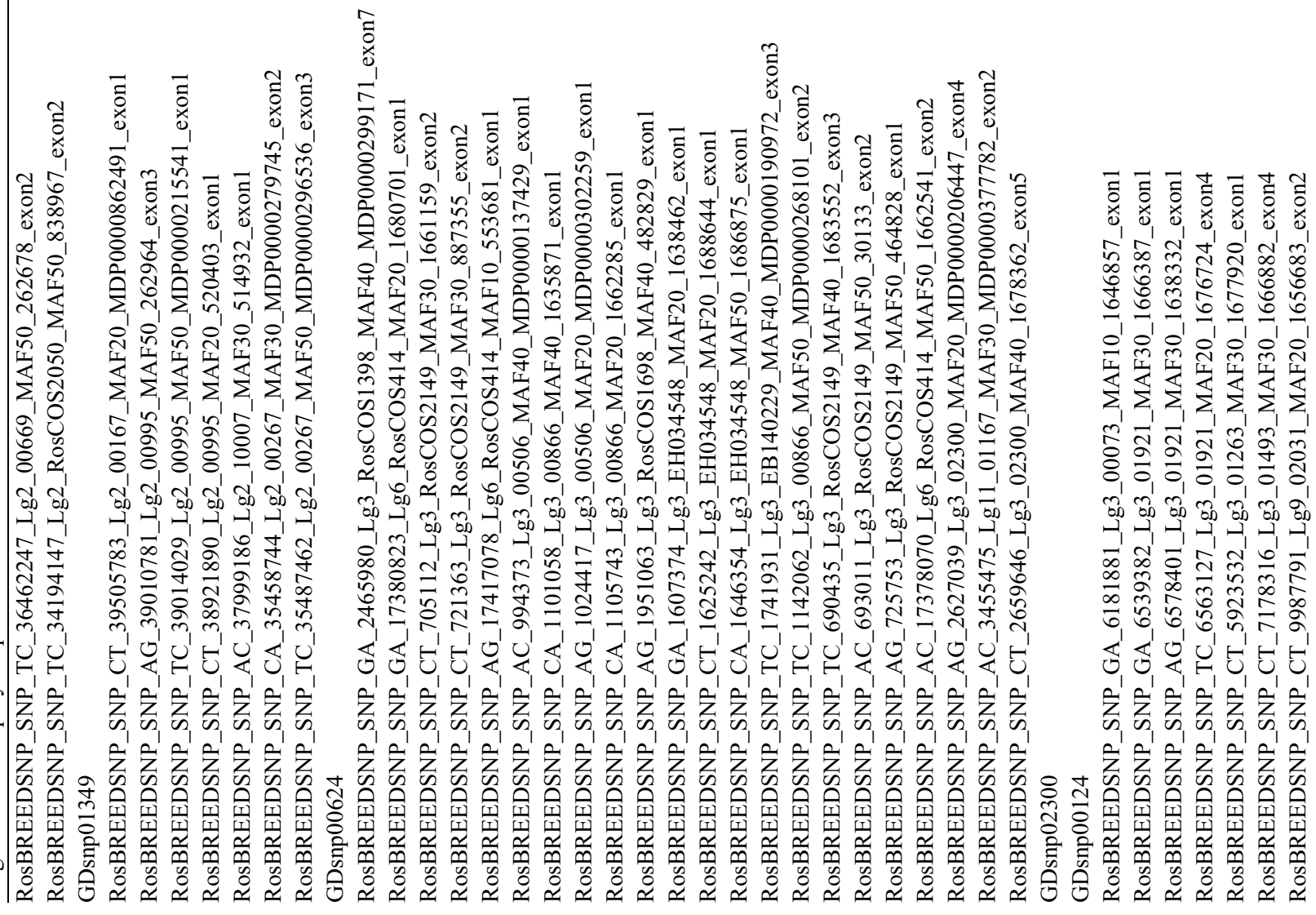




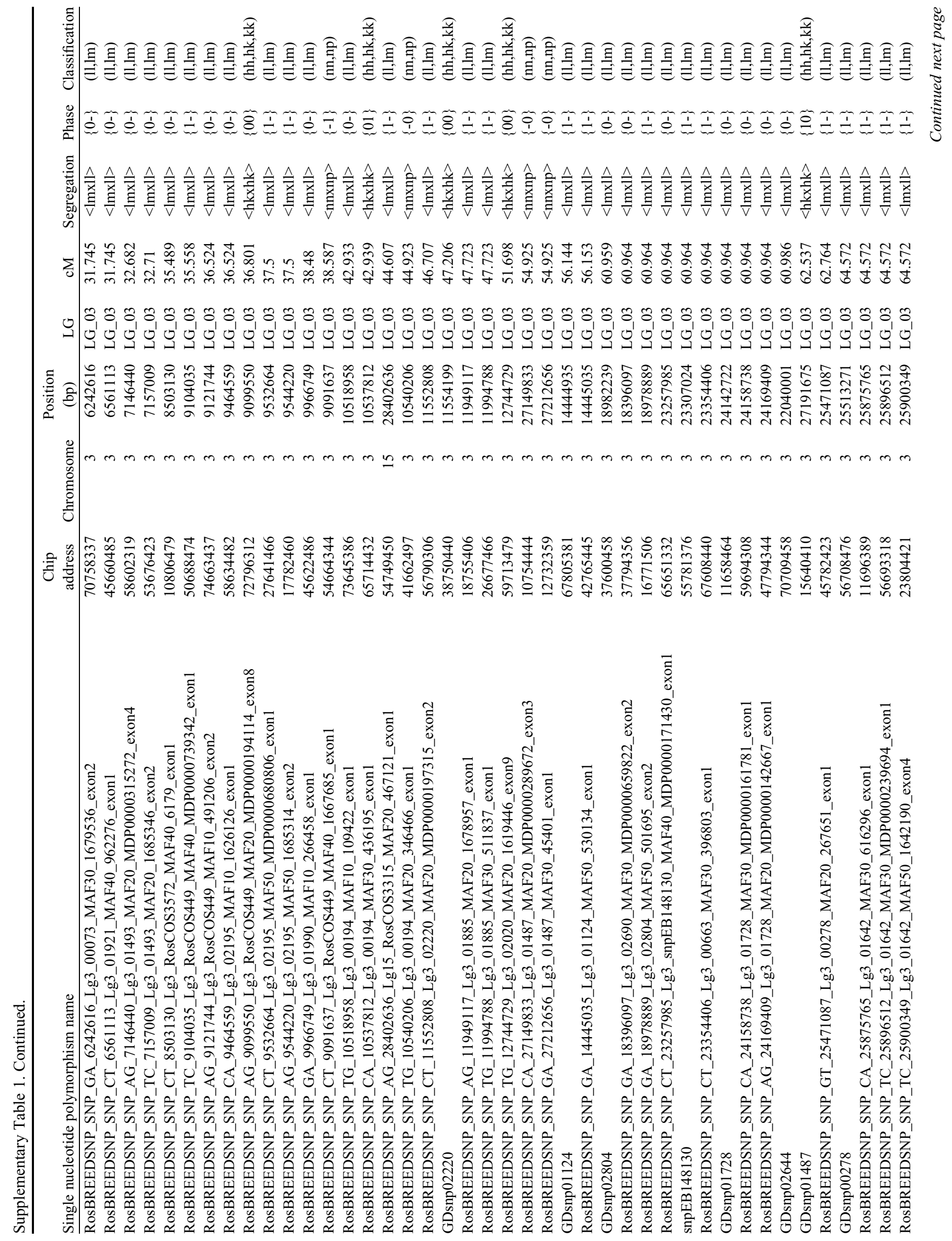




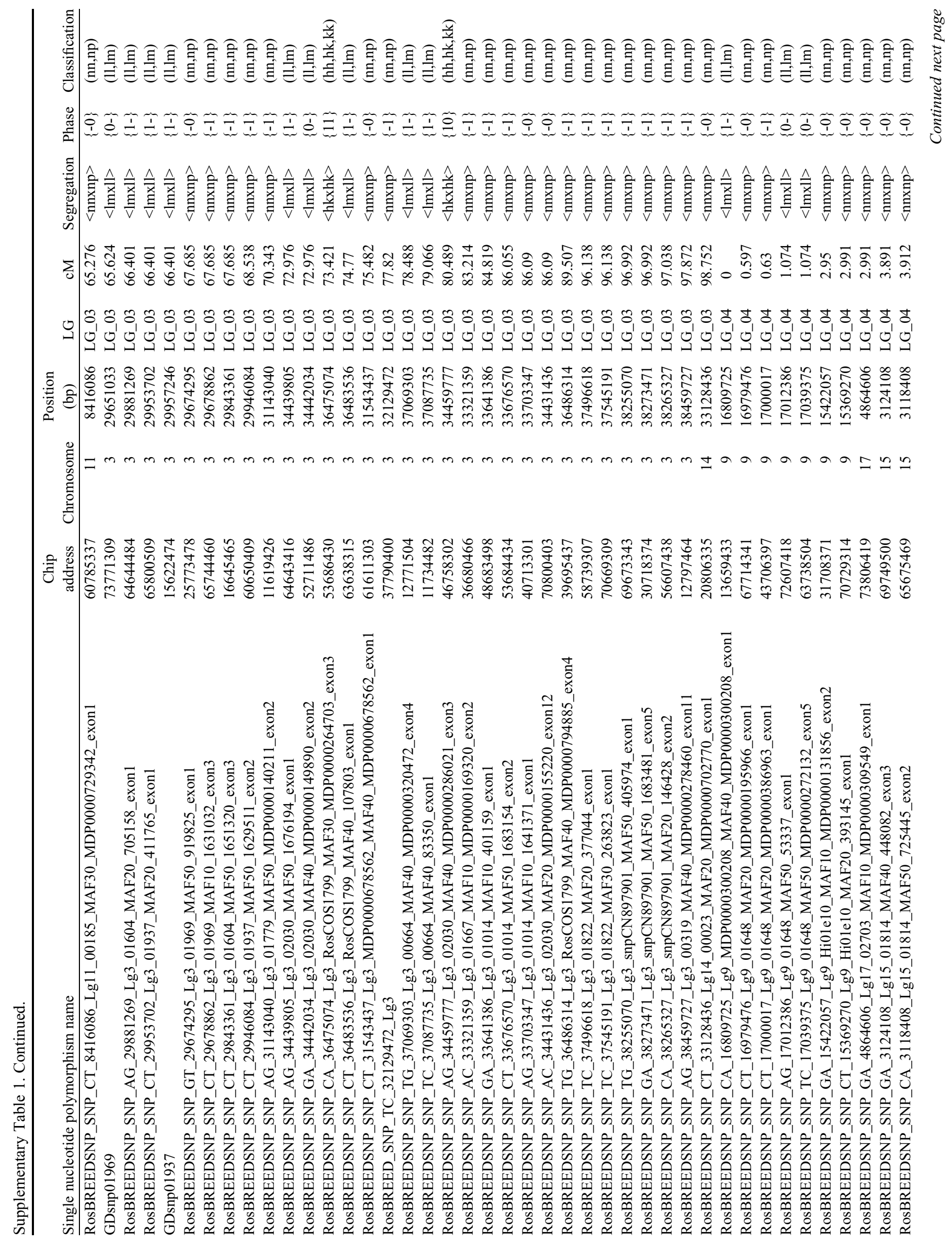




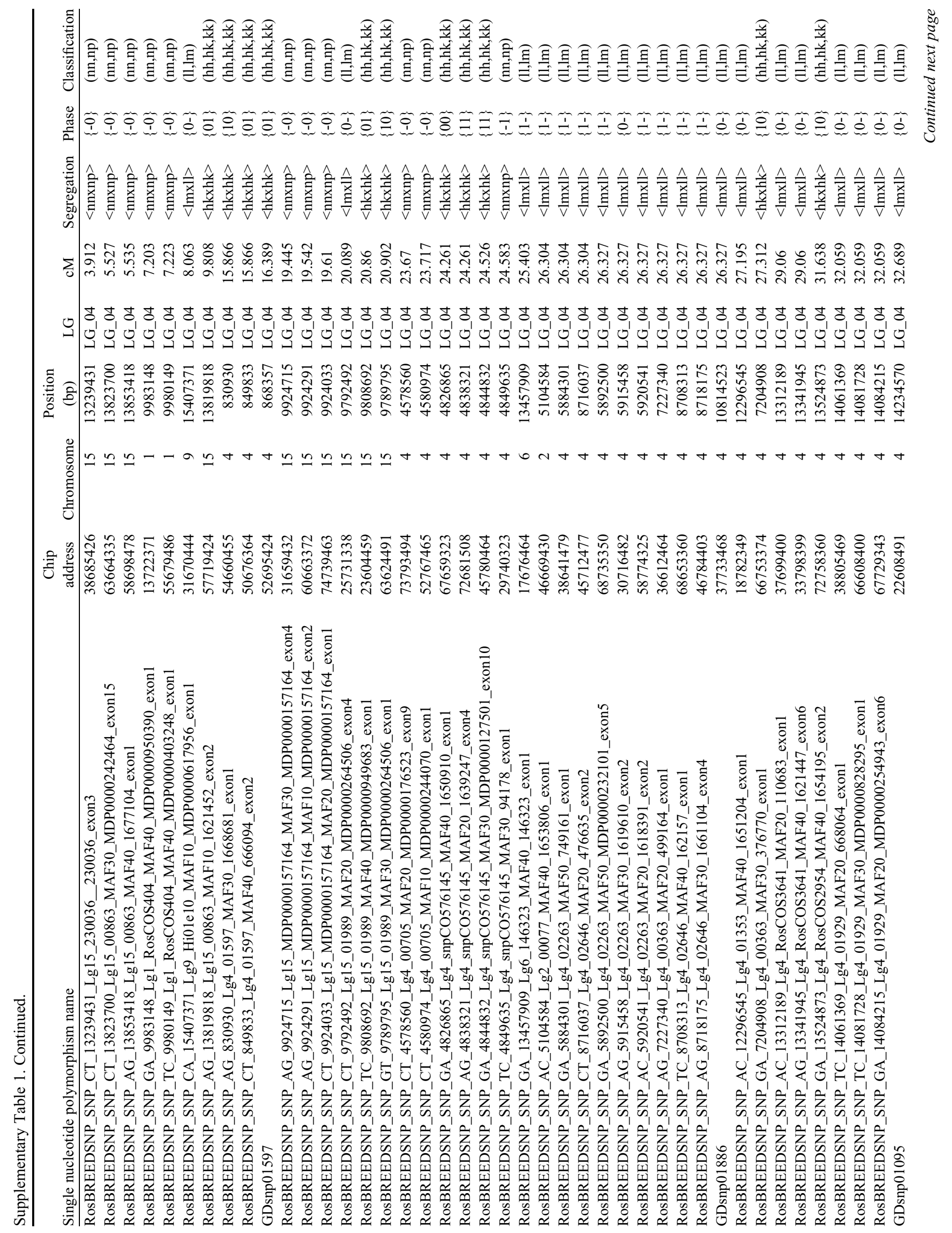




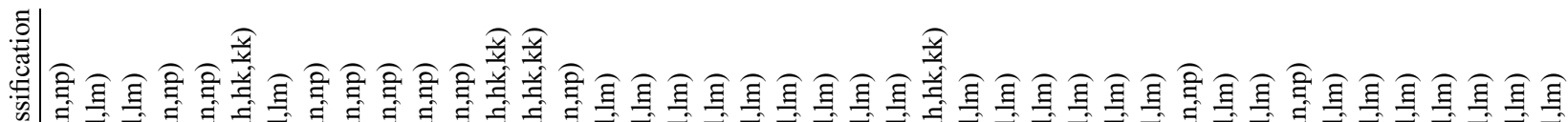

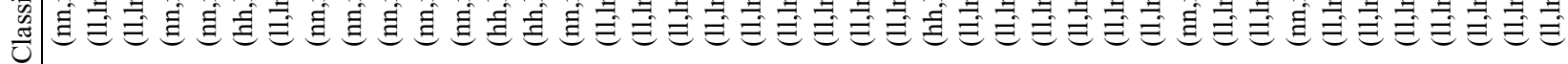

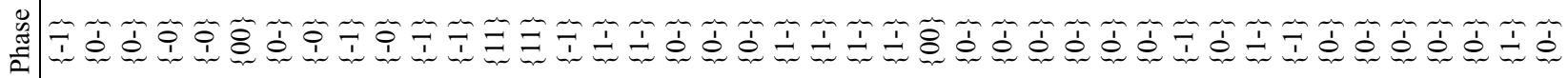

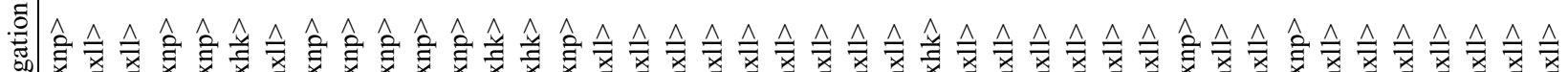

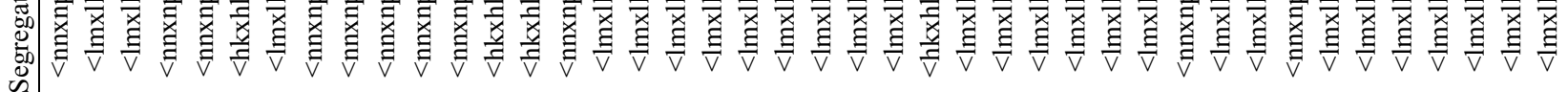

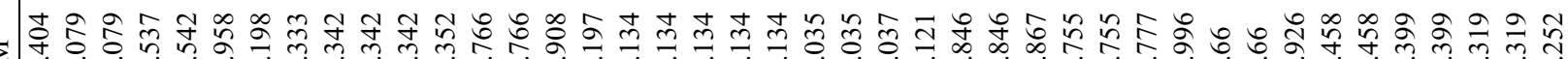

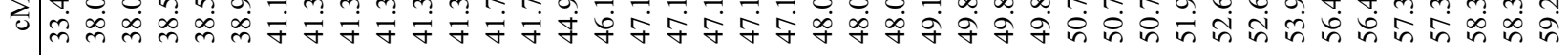

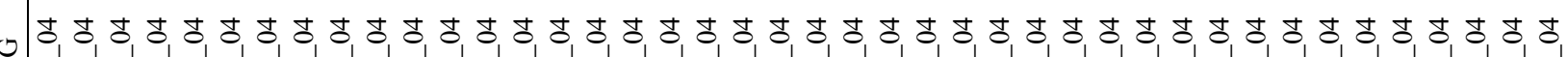

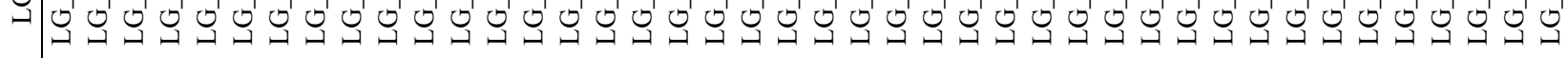

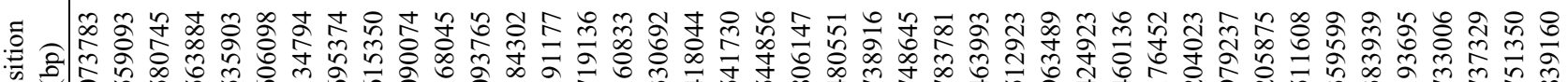

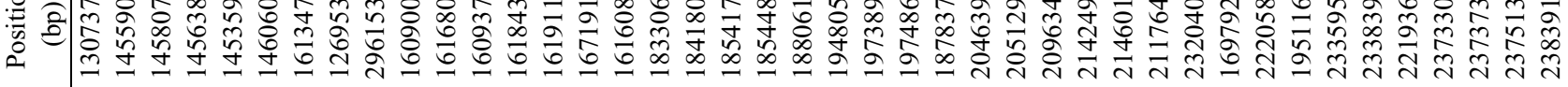

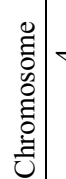

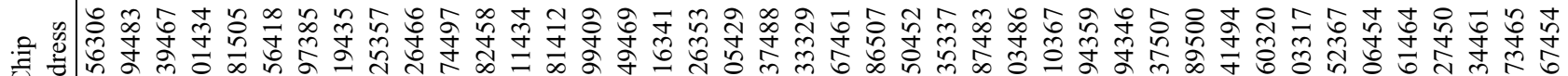

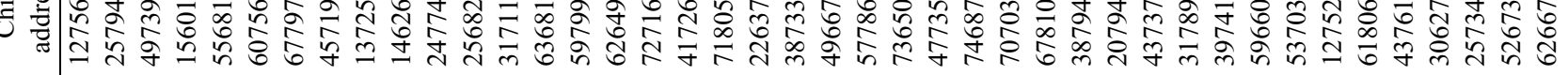

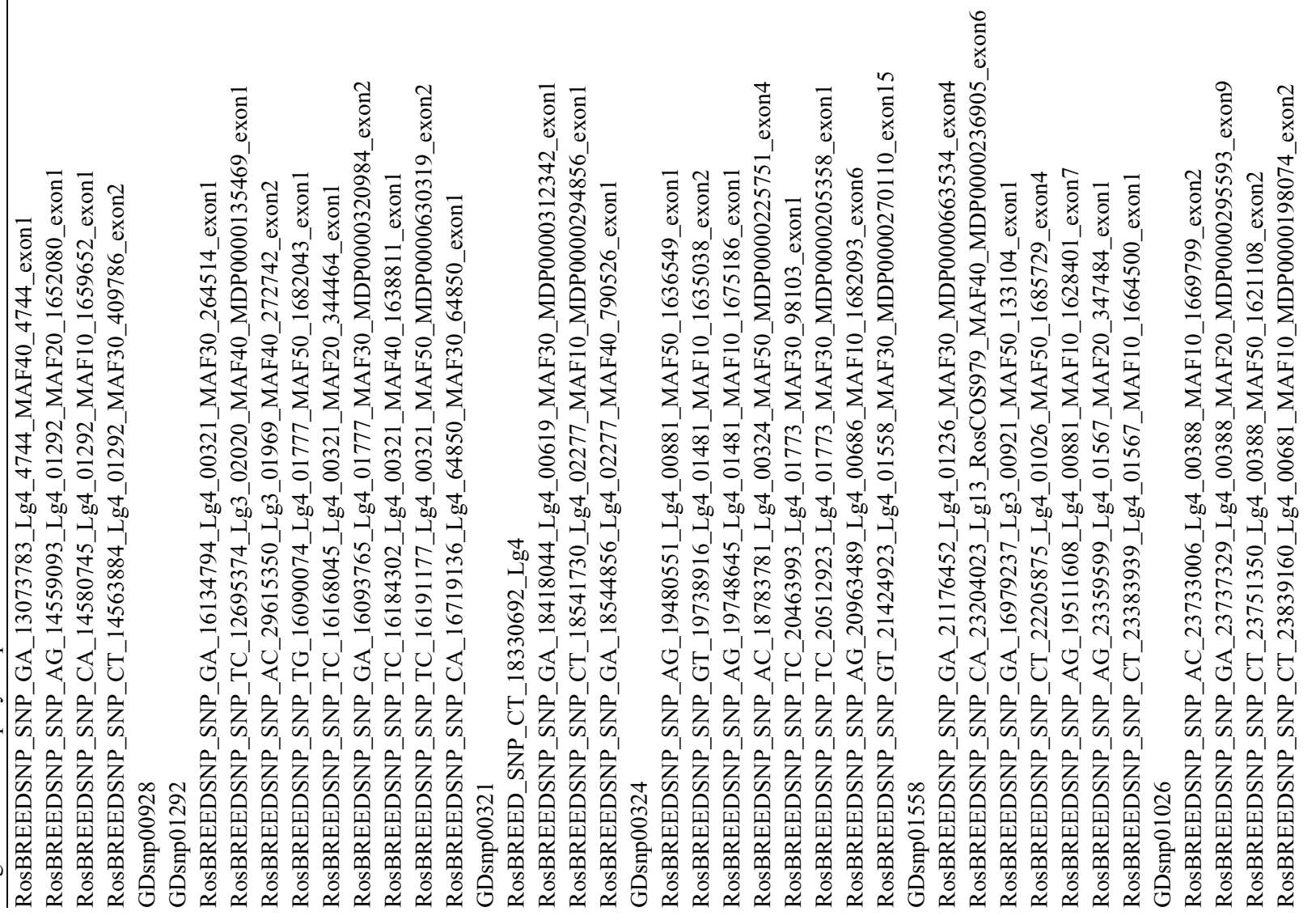




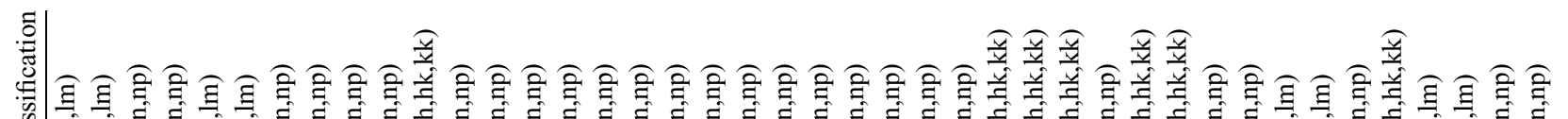

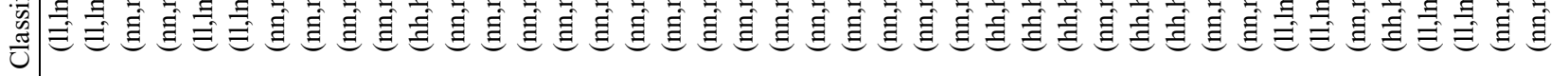

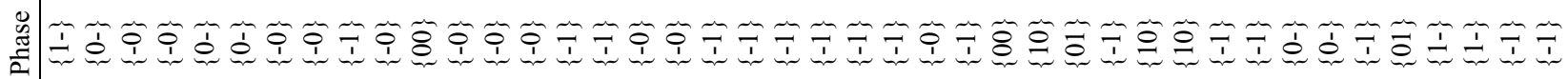

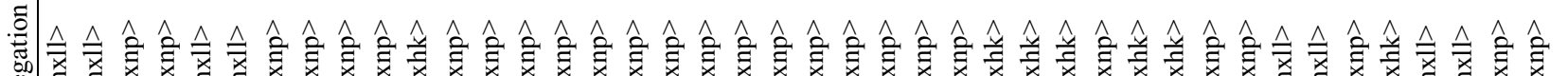

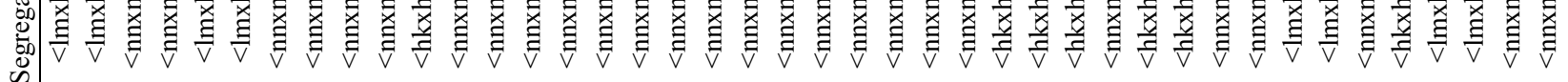

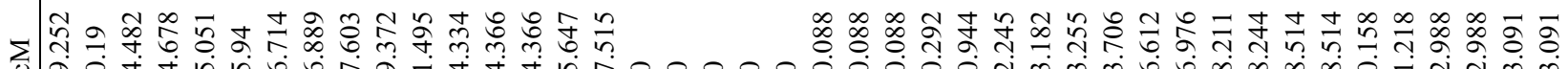

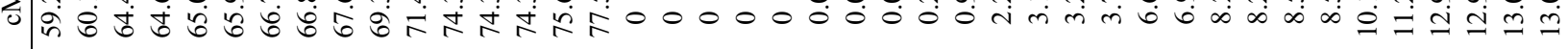

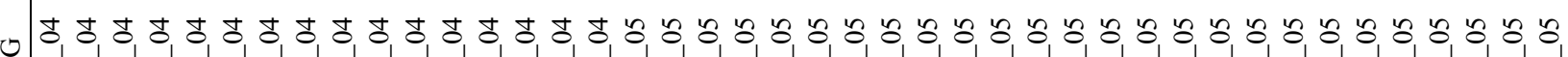

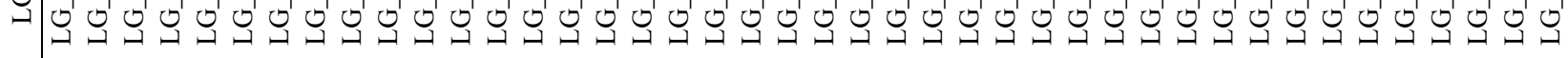

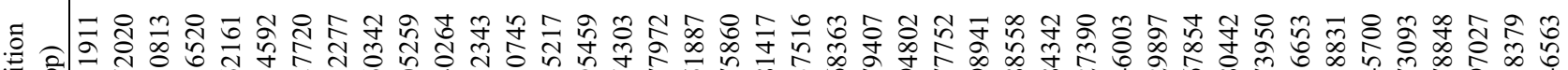

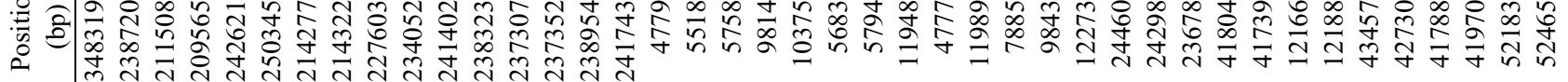
要

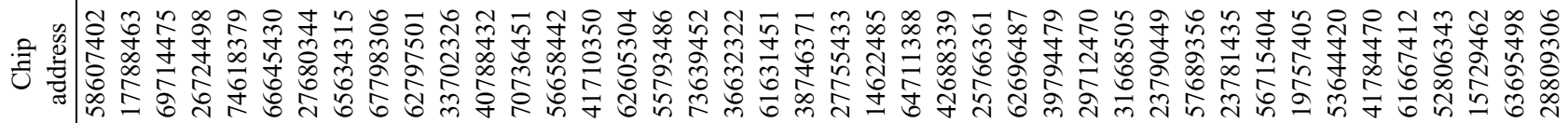

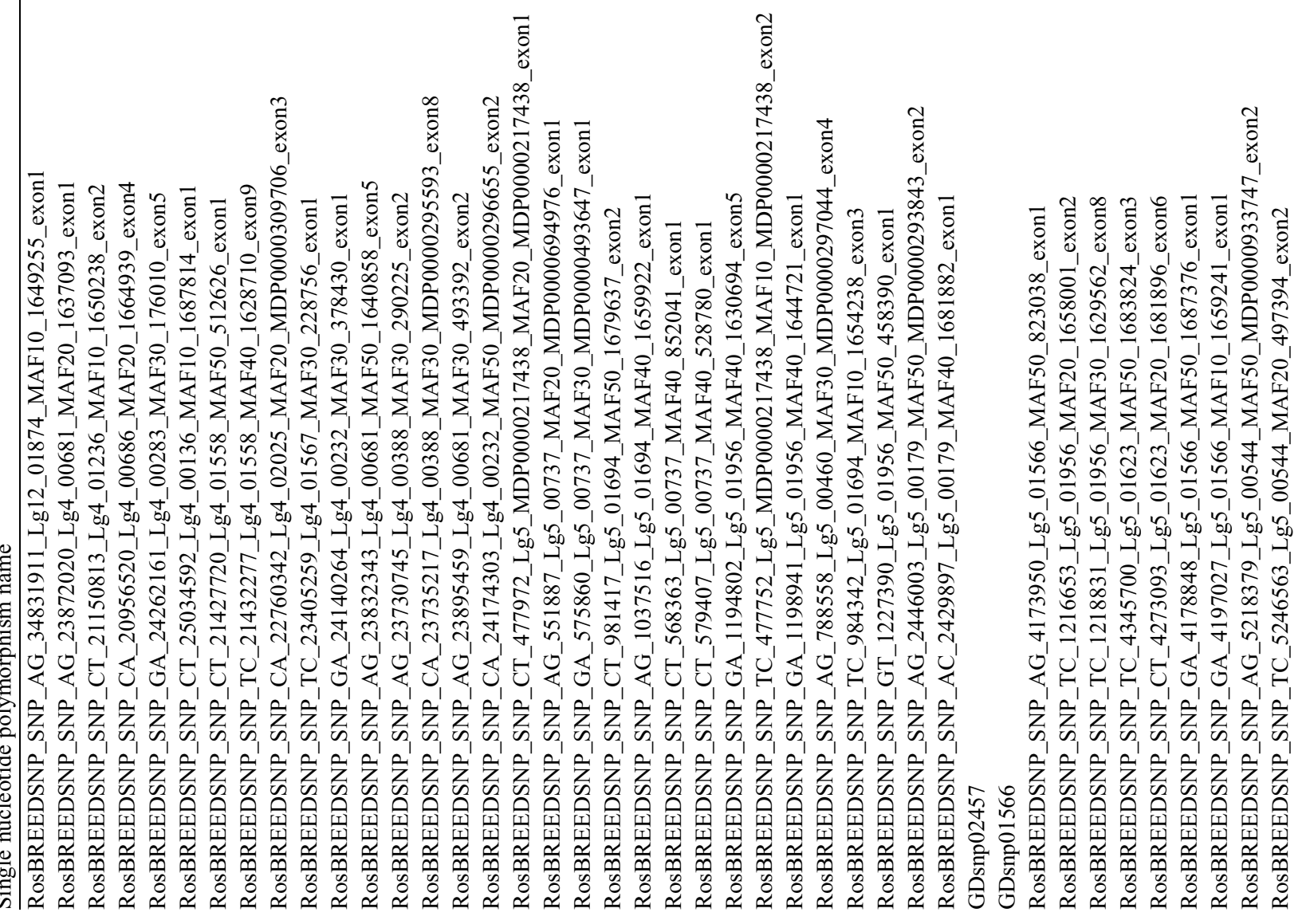




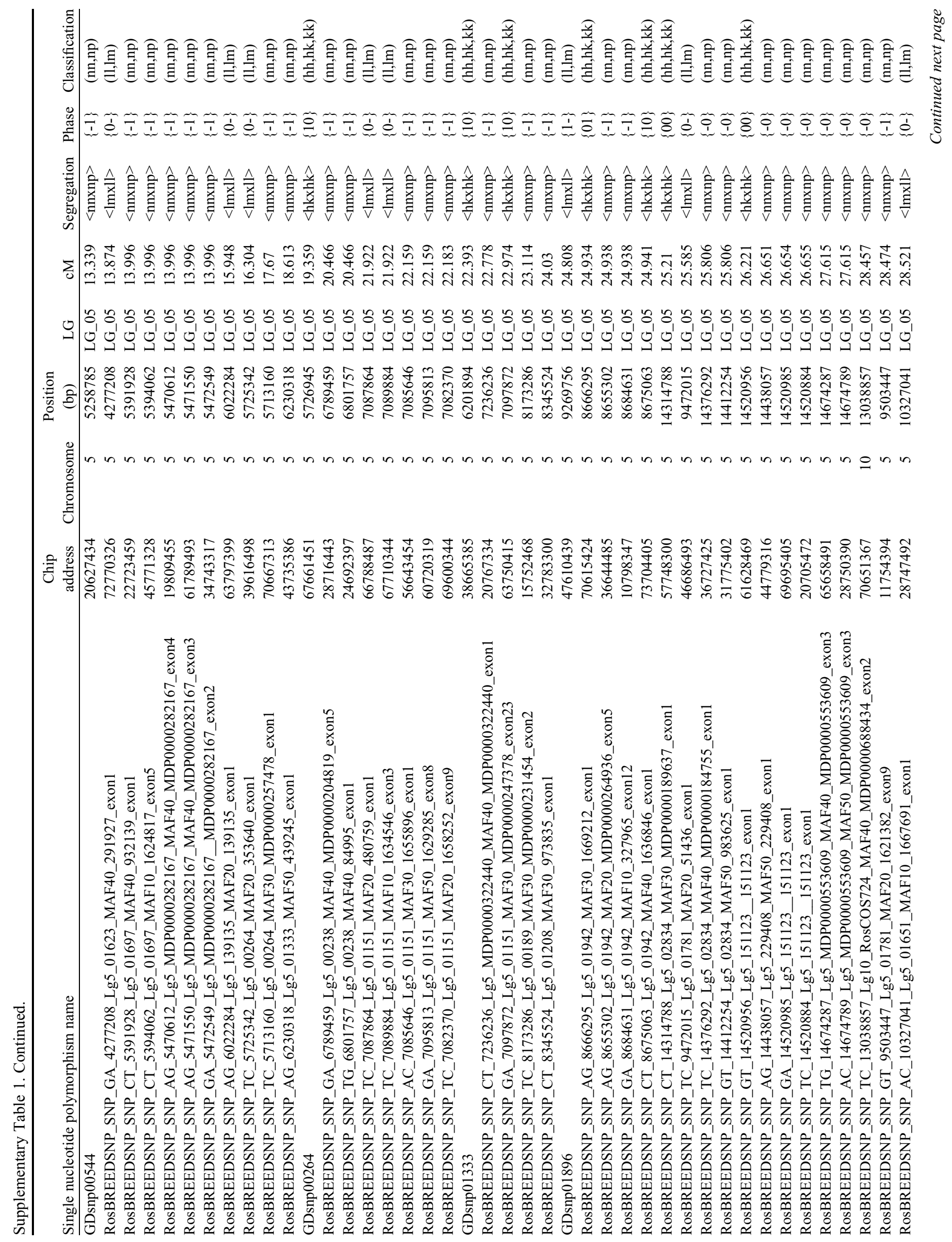




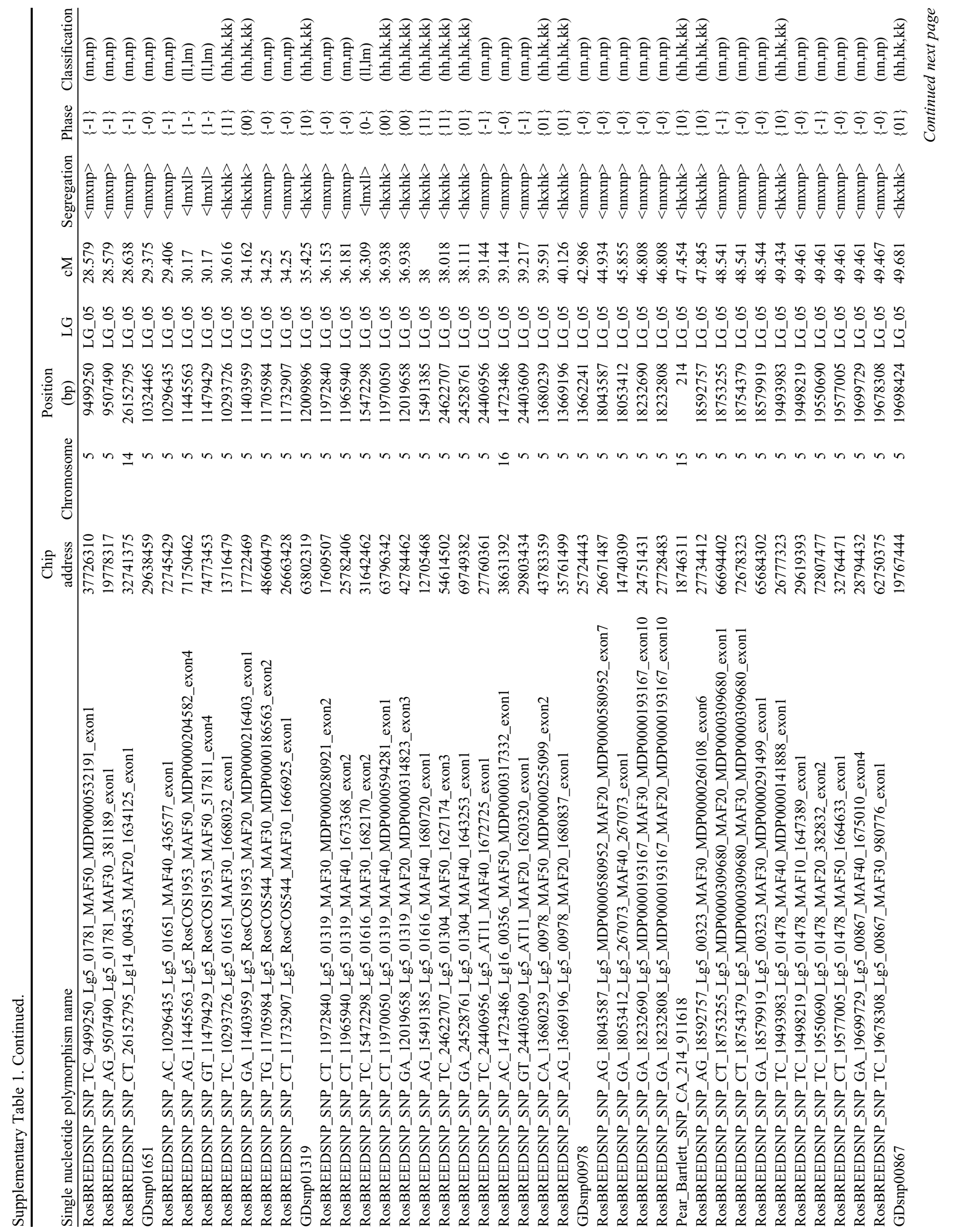




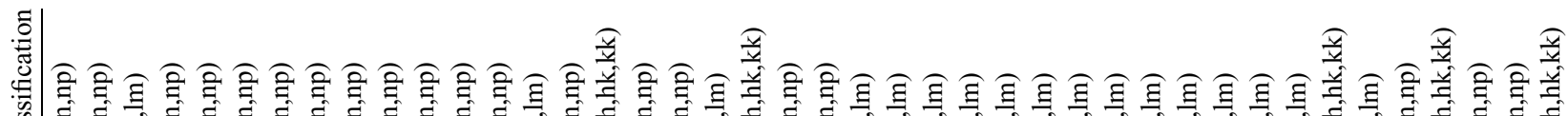

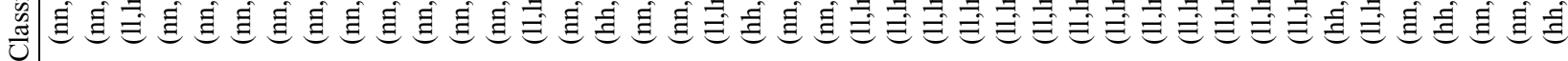

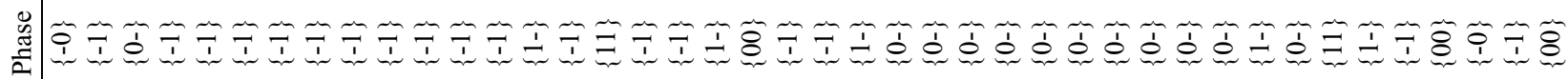

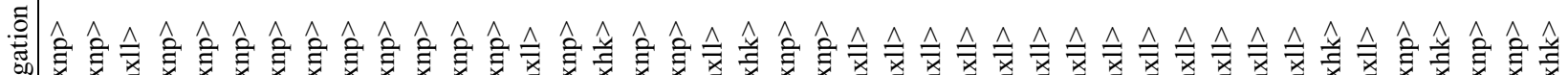

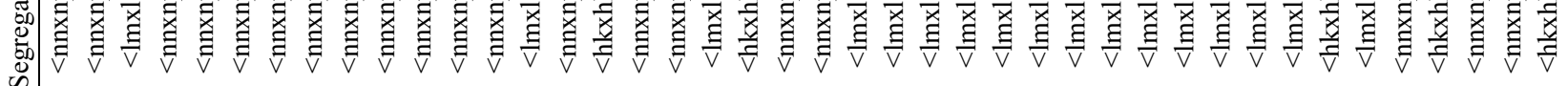
ڤ

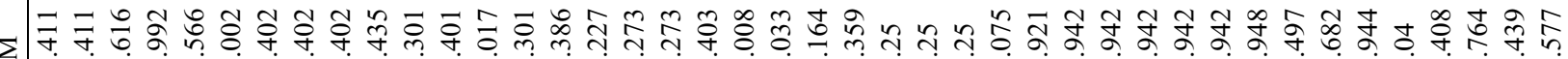

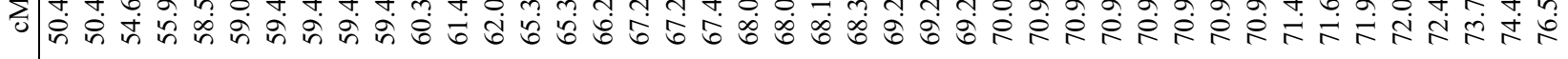

0

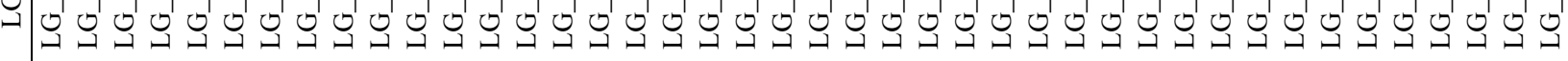

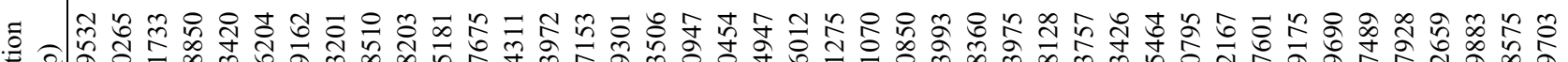

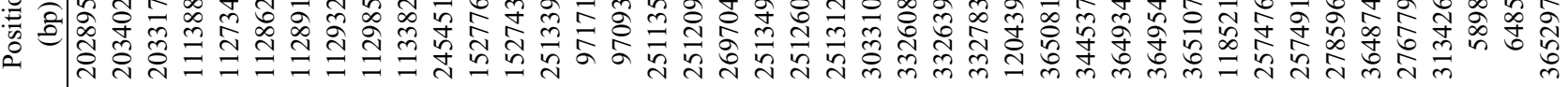
豙

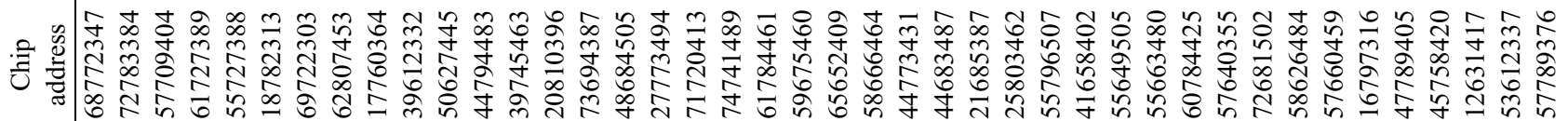

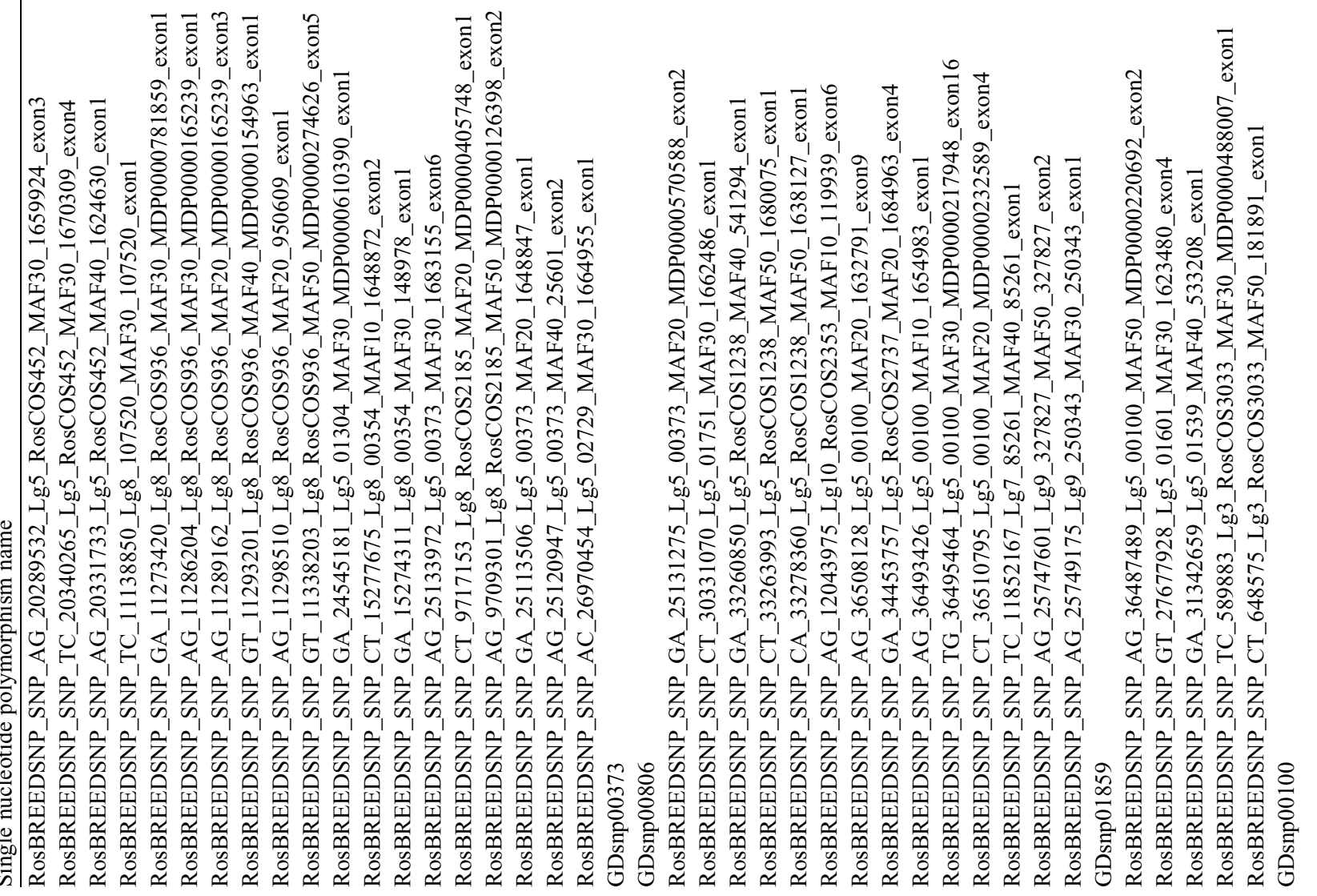




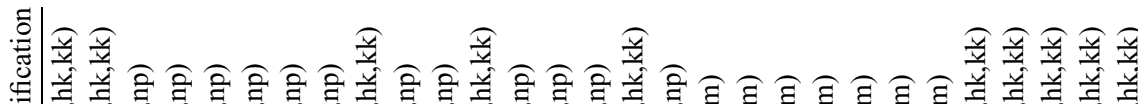

$\frac{\pi}{\underline{y}}$

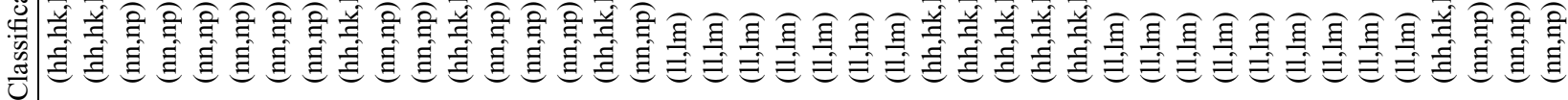

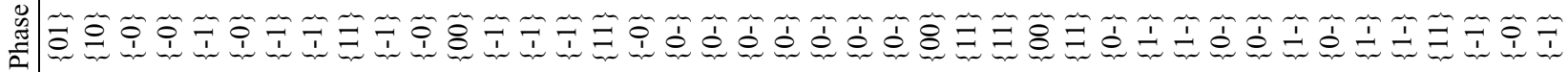

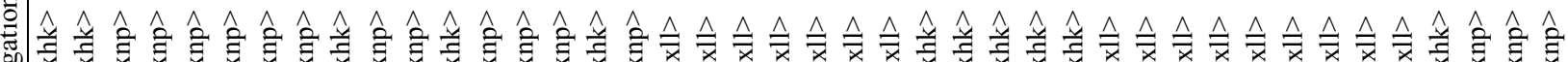
它

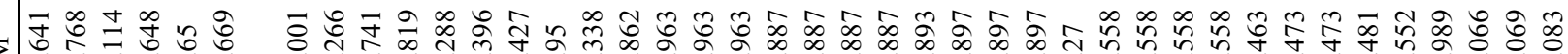

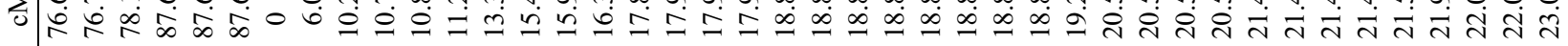

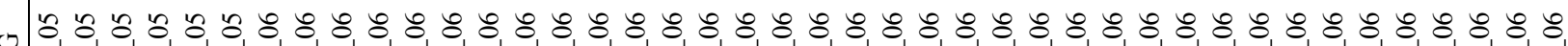
-

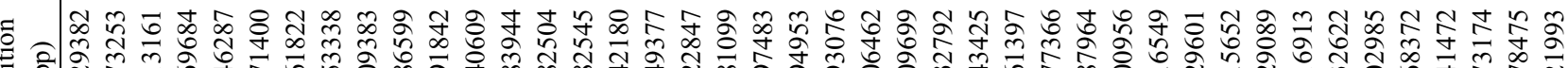

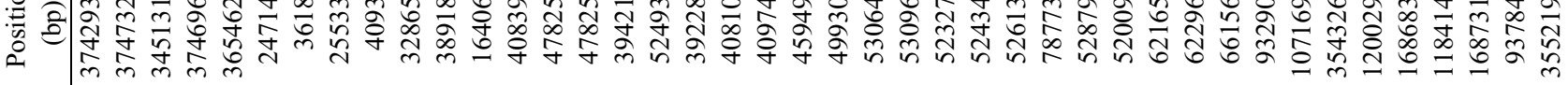

:

已)

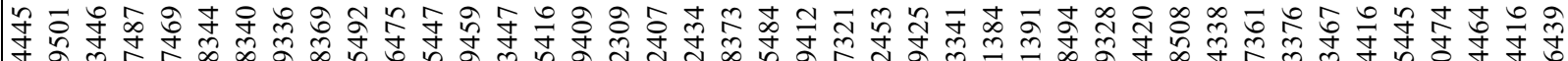

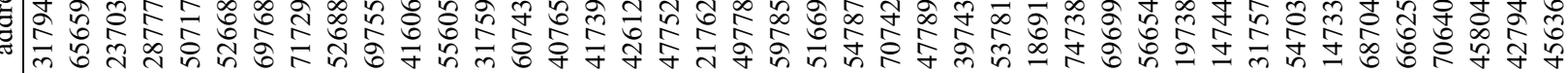

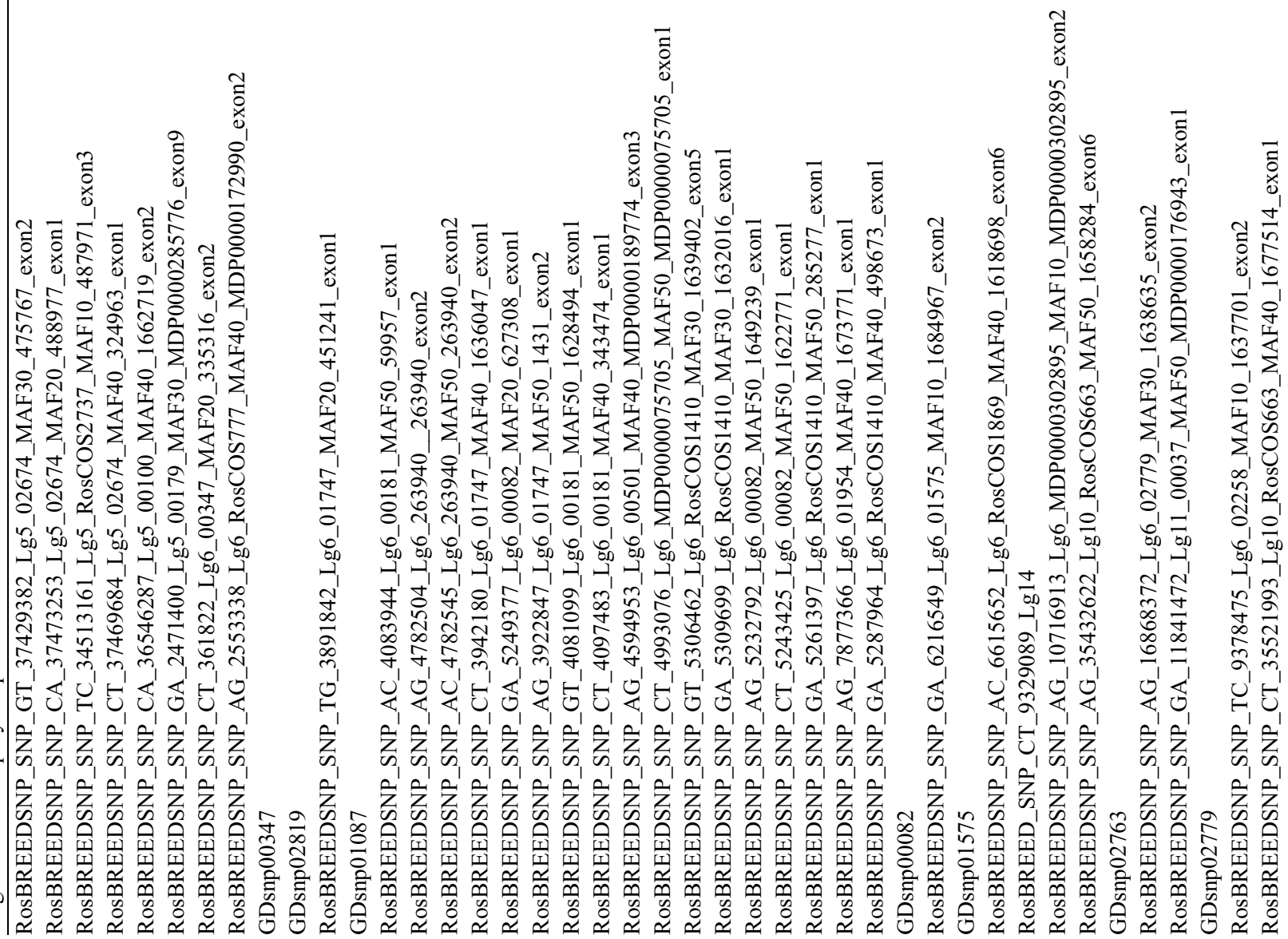




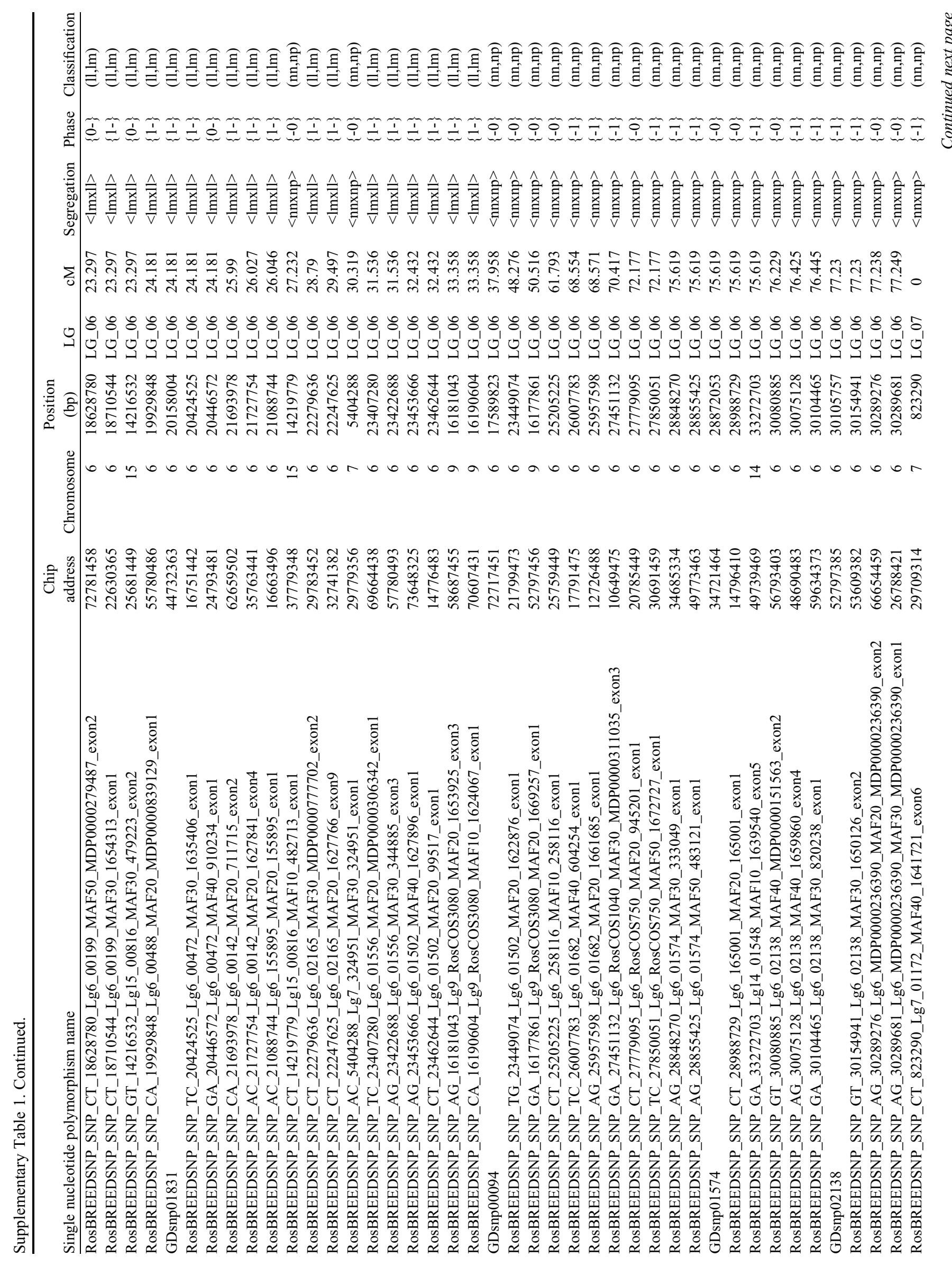


:

要

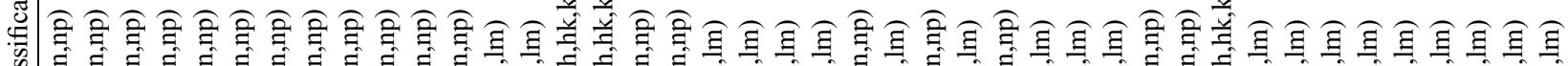

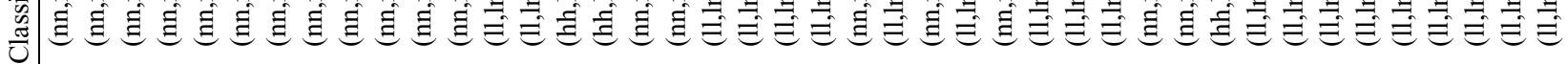

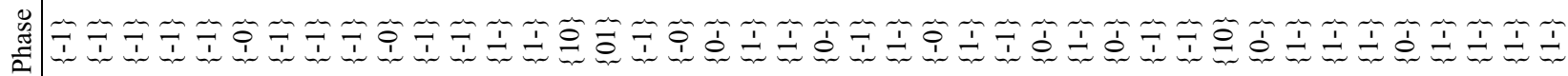

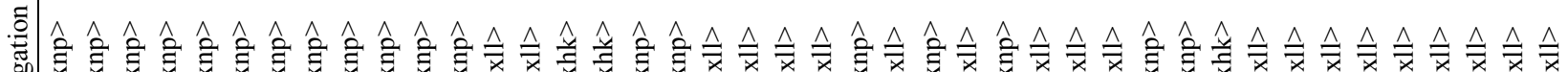
它

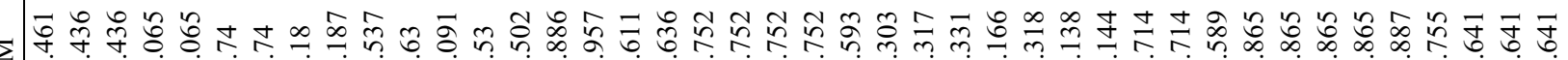

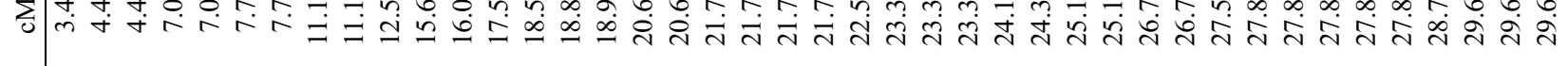

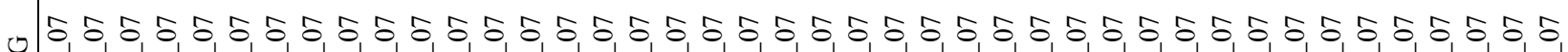

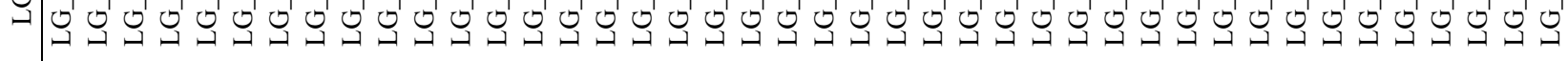

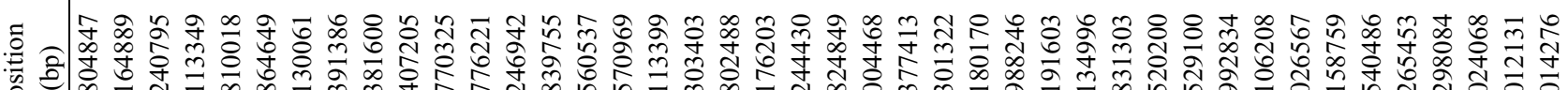

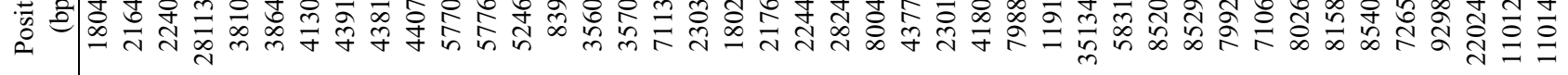
离

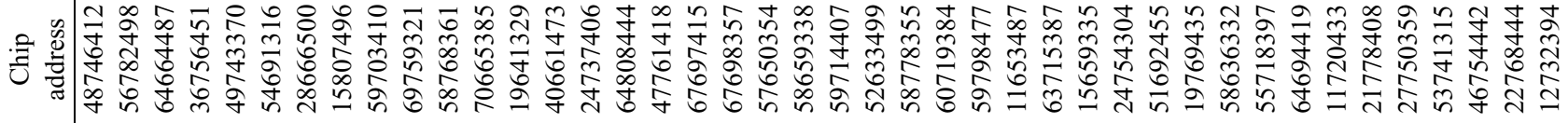

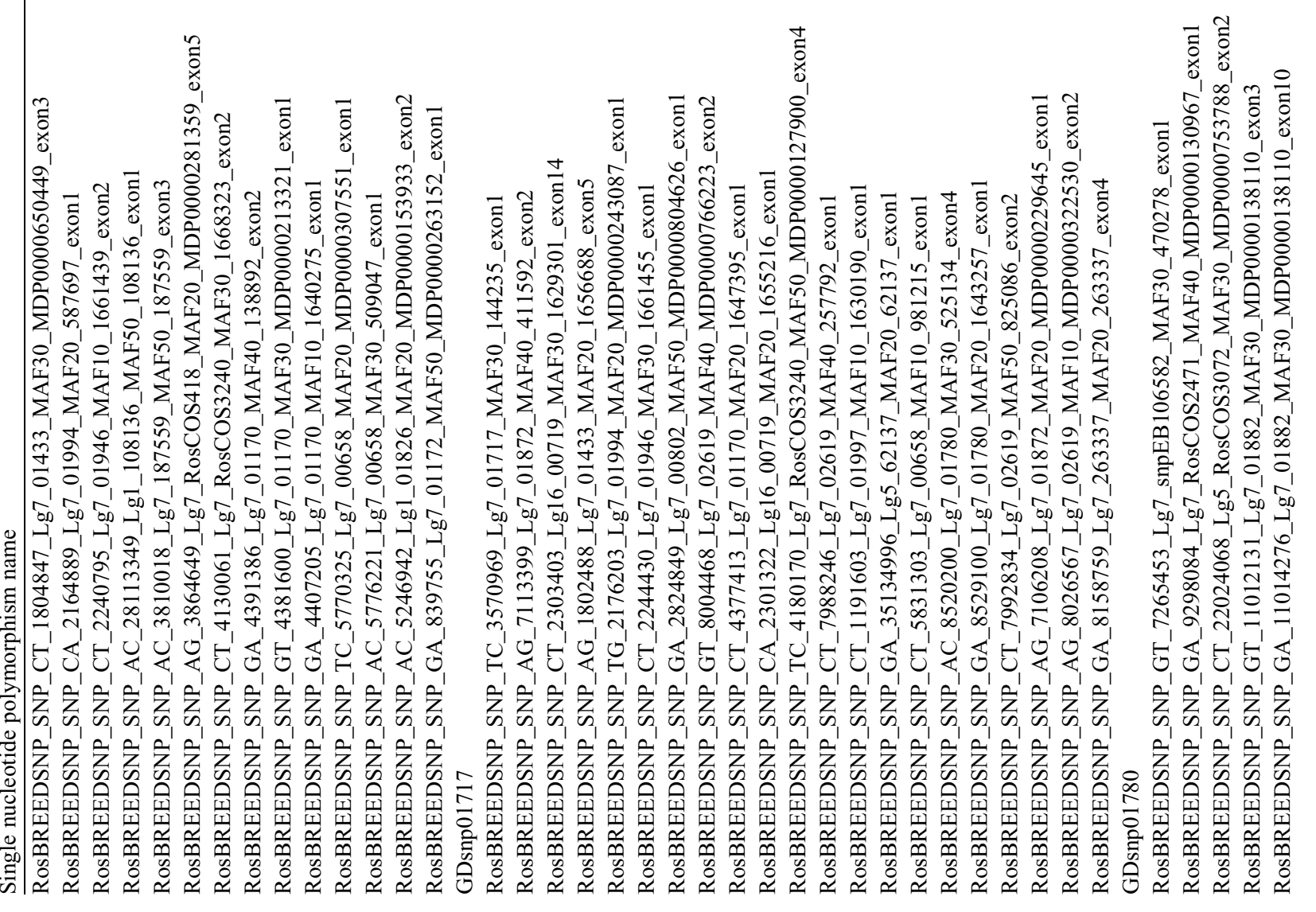




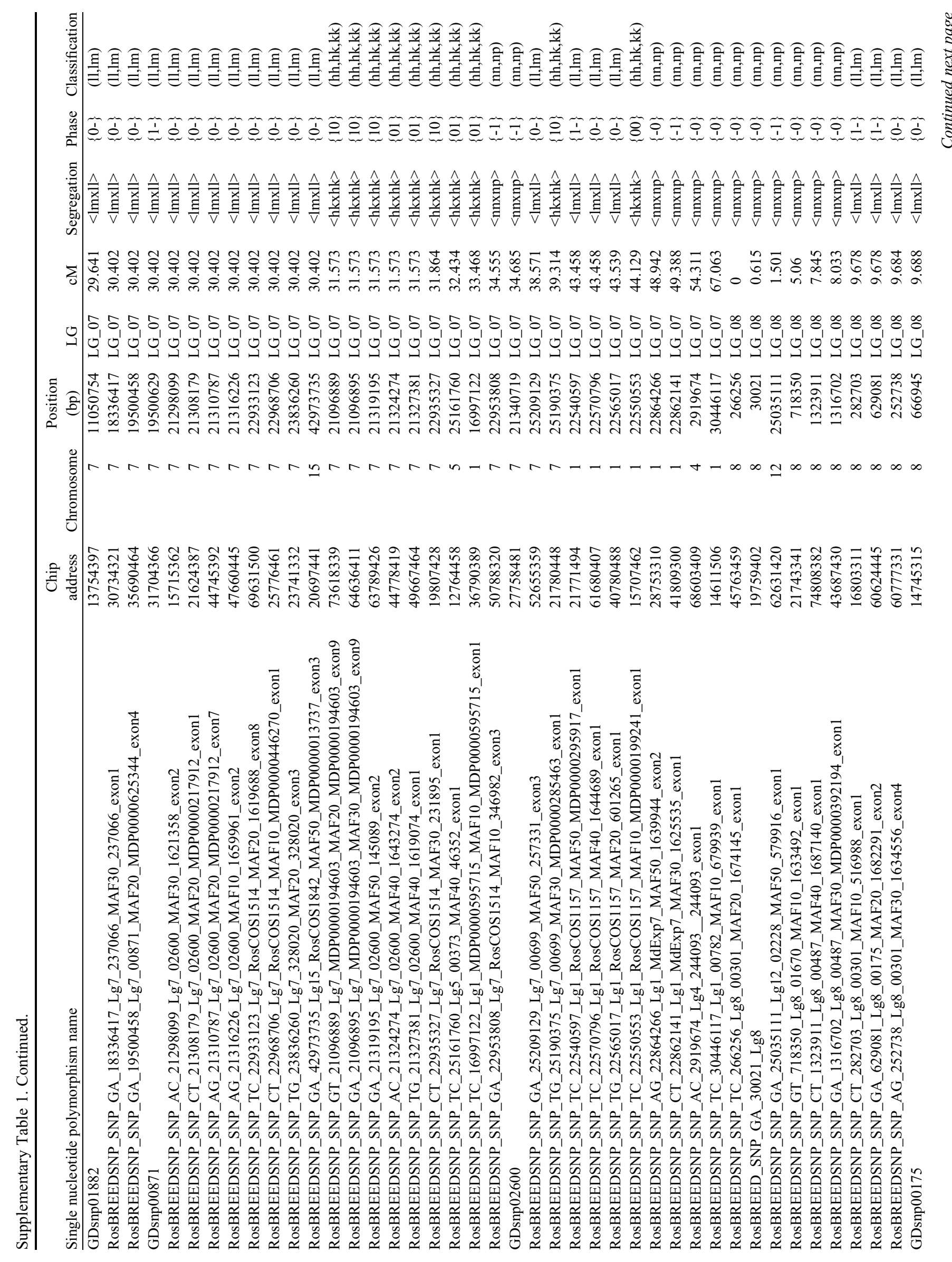




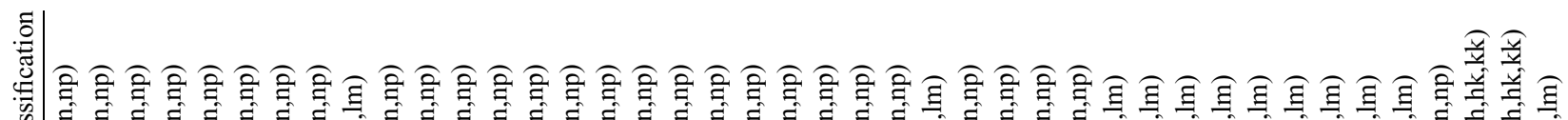

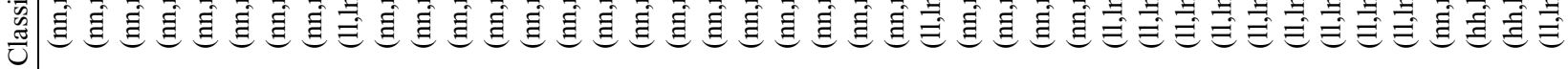

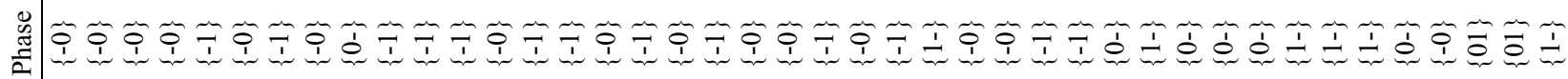

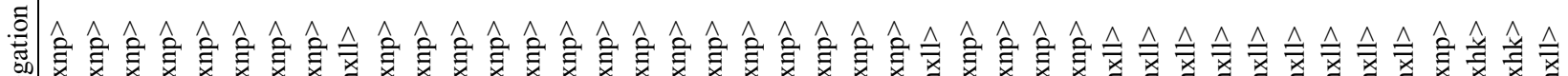

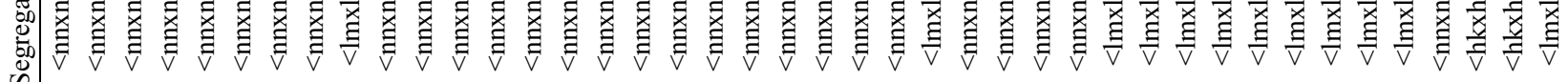

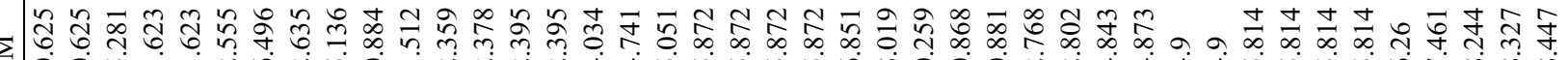

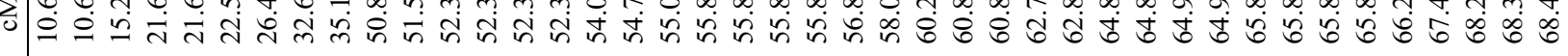

0 -

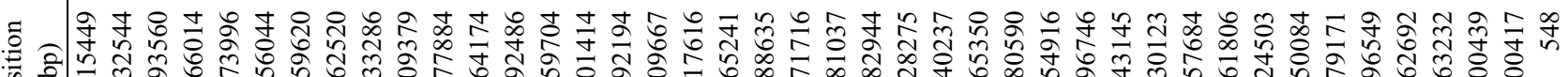

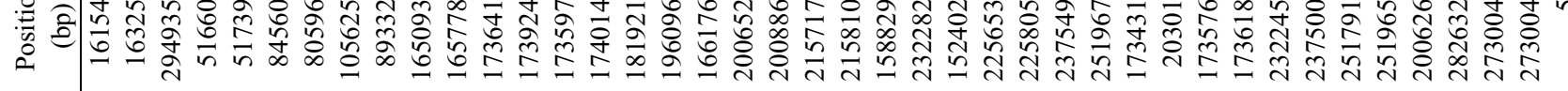

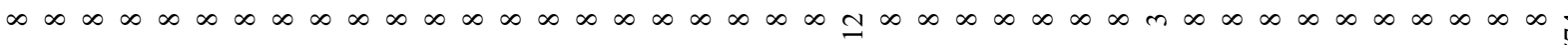

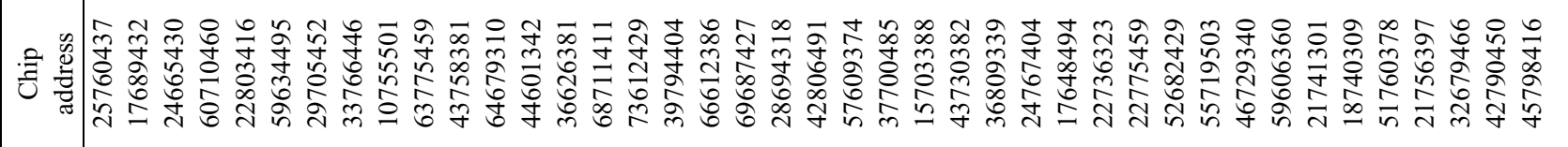

$\tilde{\overline{0}}$

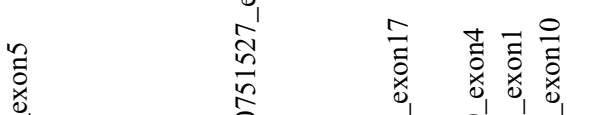

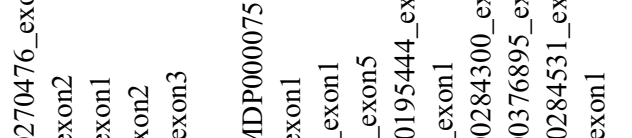

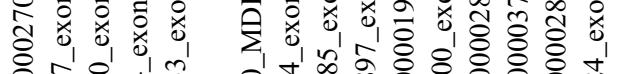

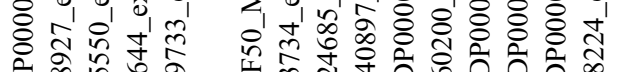

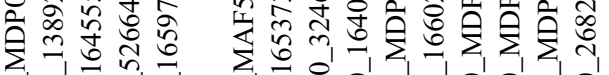

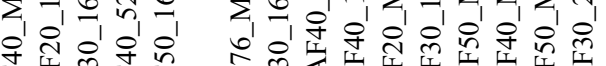

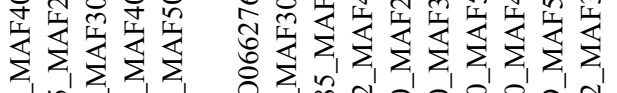

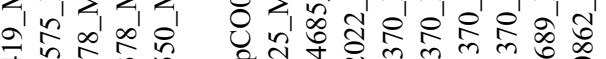

क्षे

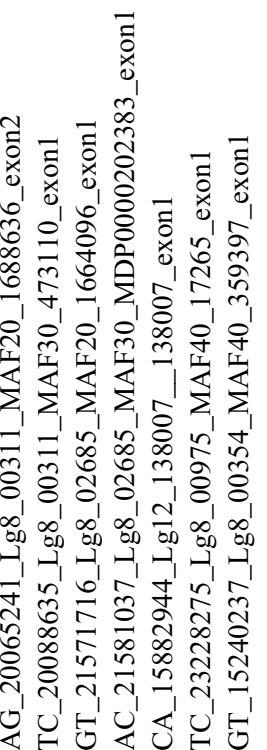

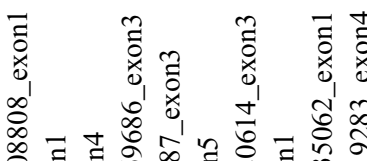

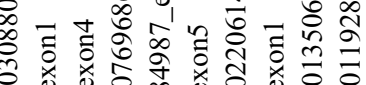

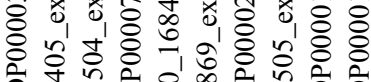

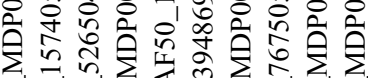

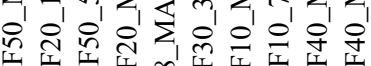

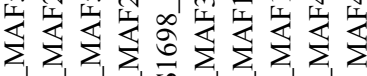

on

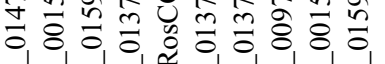

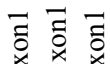

के

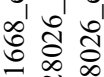

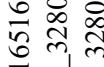

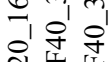

我要这

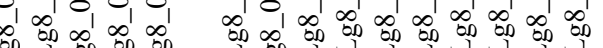

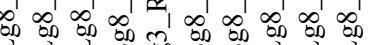

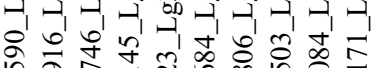

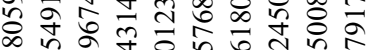

ते हैं

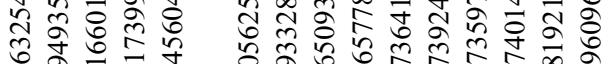

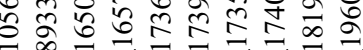

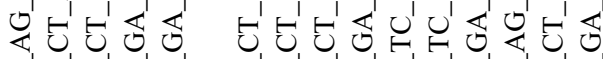

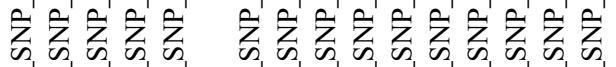

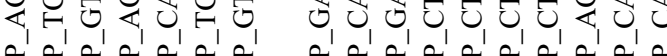

$\sum_{1} \sum_{1}$

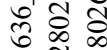

$\approx$,

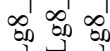

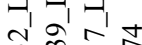

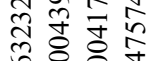

贾

至

U.

会会会

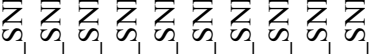

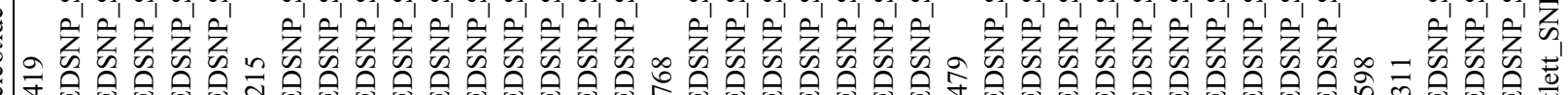

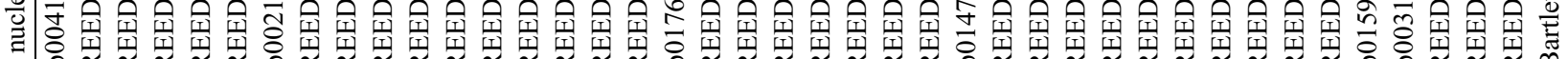

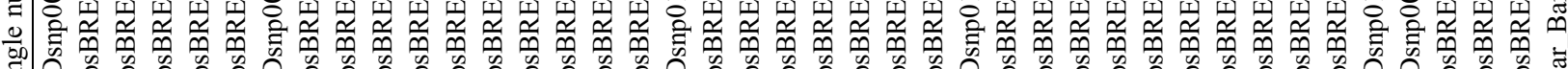

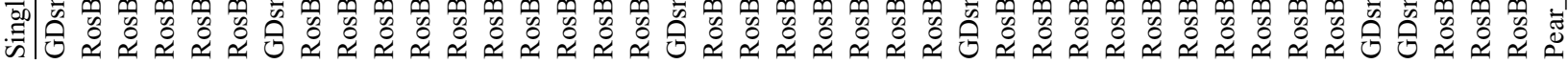




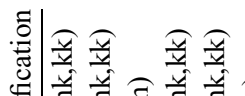

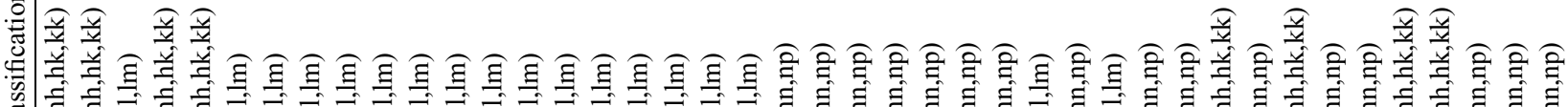

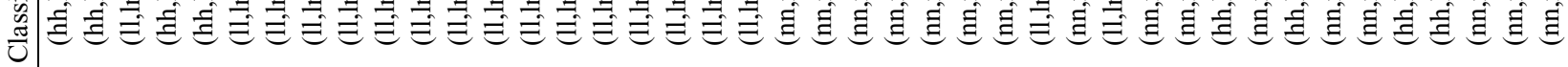

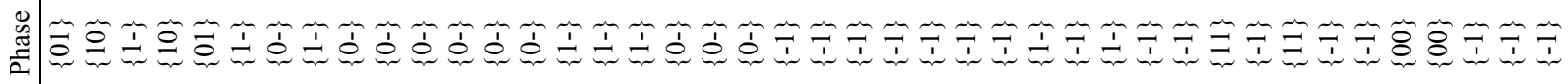

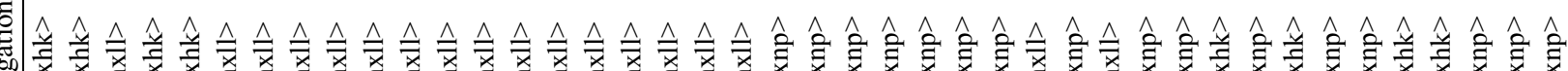
至

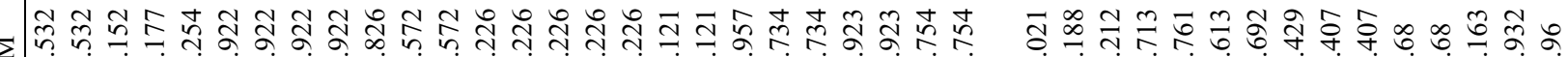

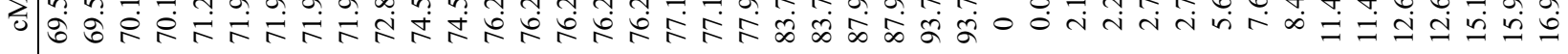

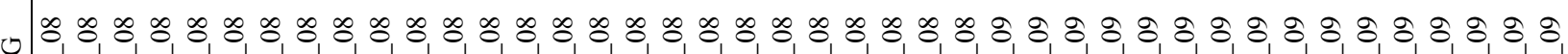

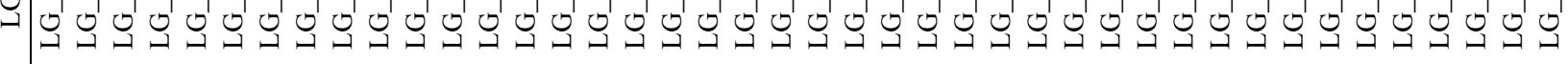
б

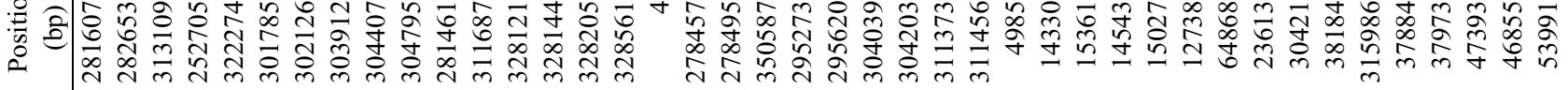

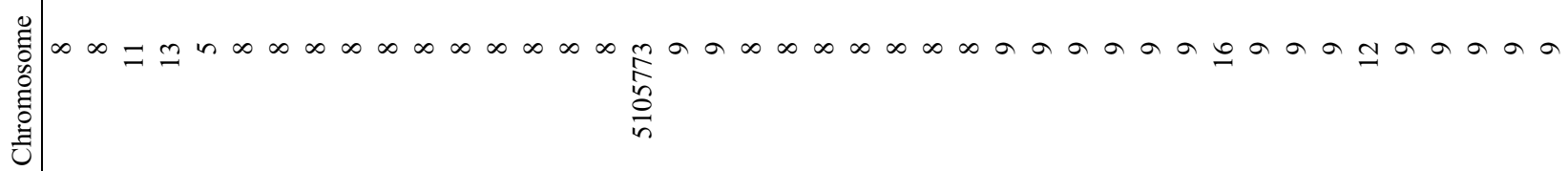

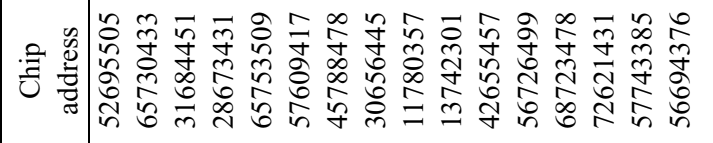

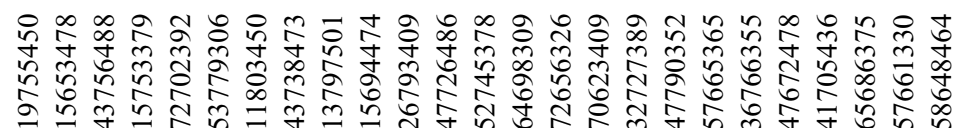

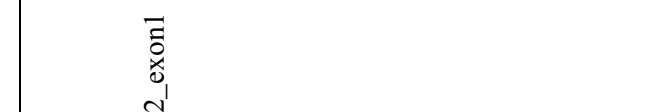

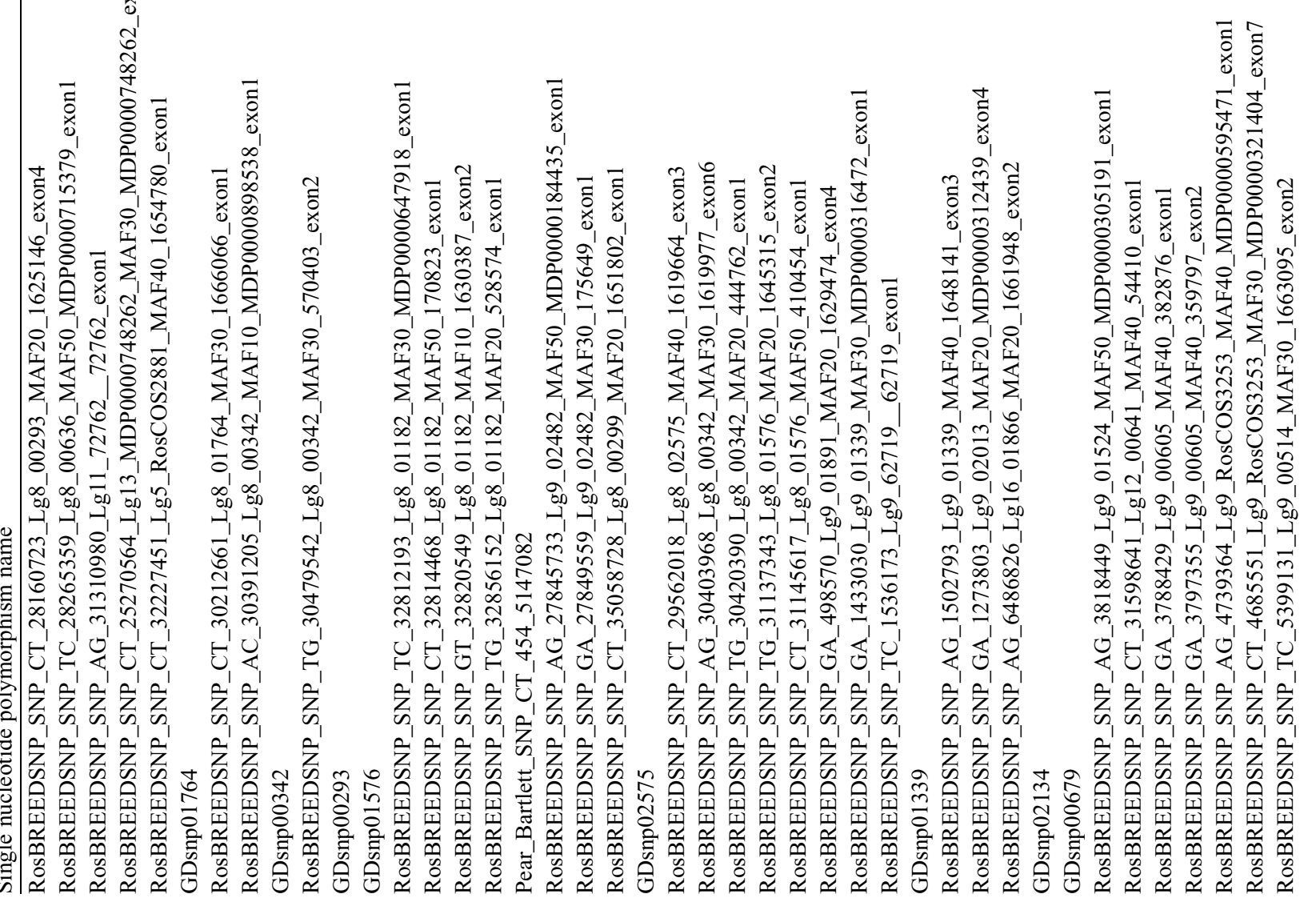


童

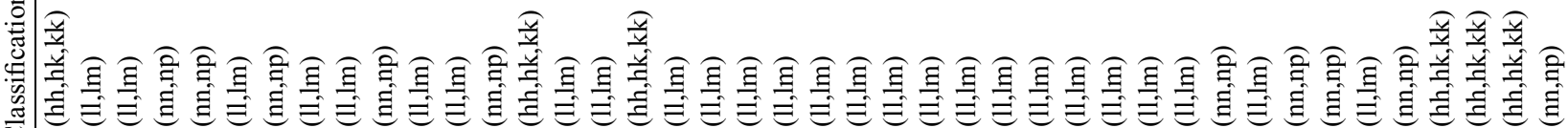
Uँ

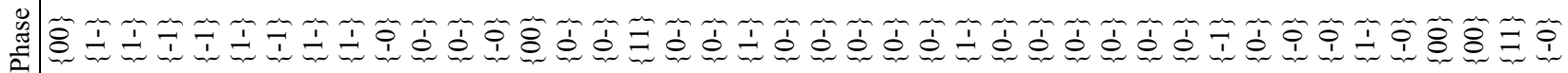

. ํำ

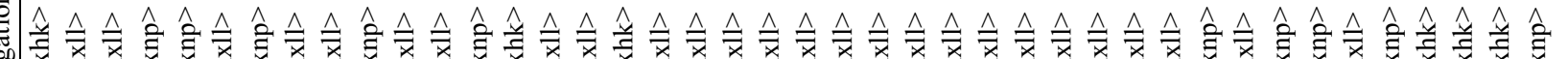

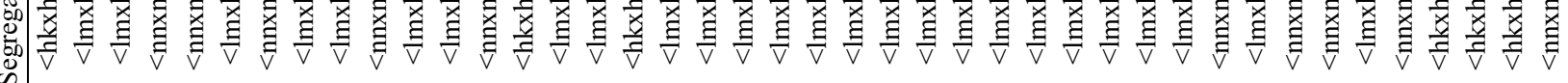

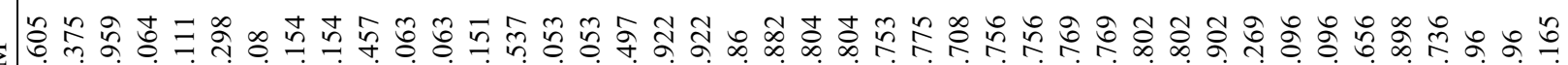
र

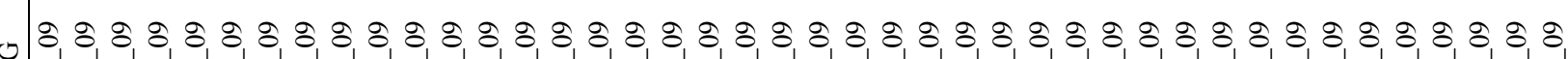
-

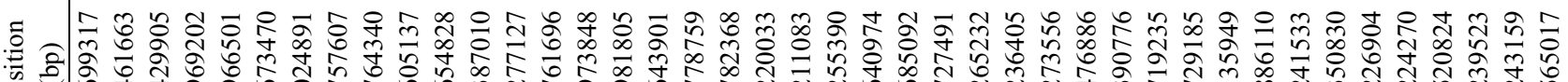

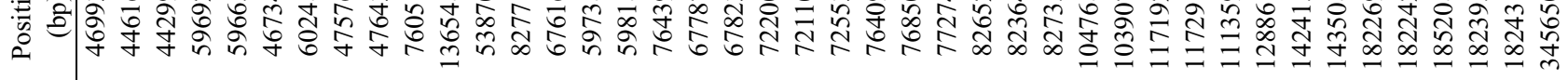

范

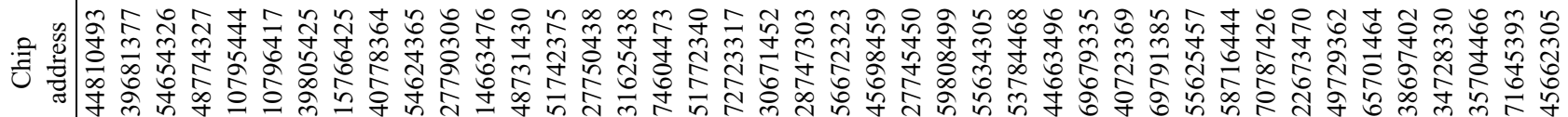

a

ia a a ina a a a 


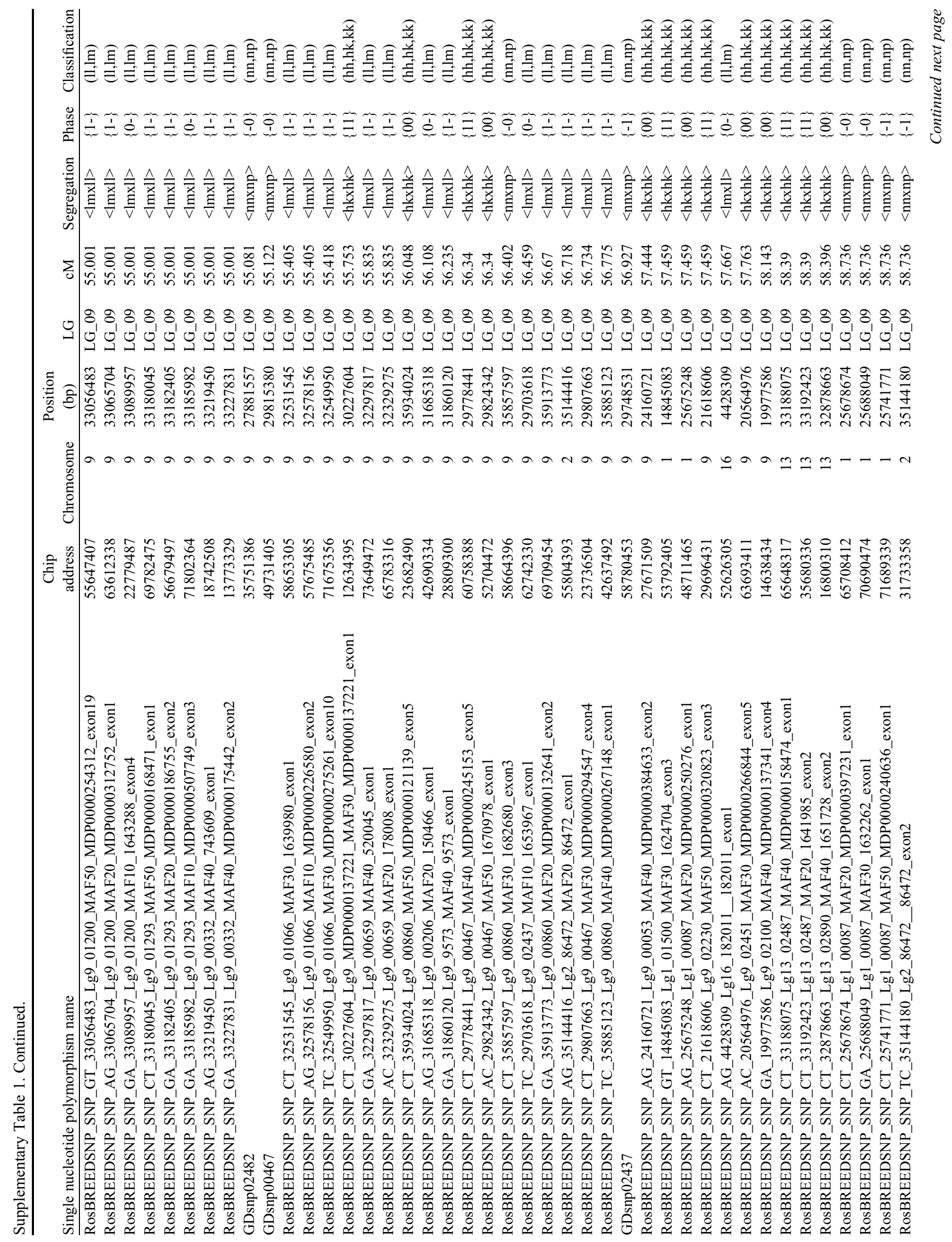




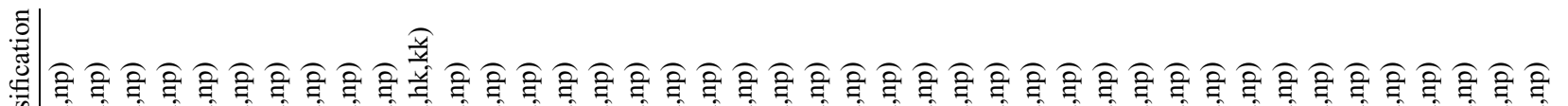

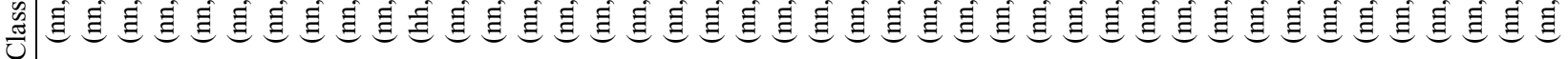

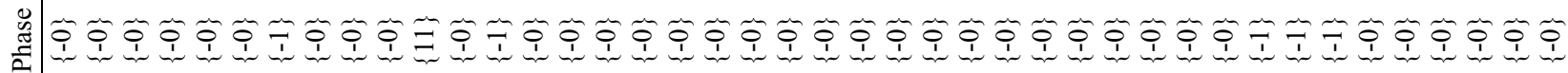

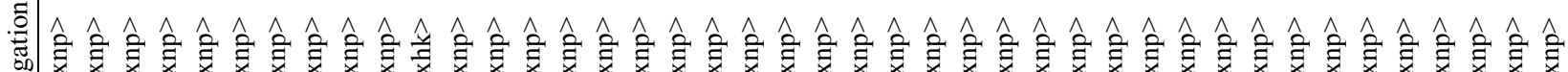

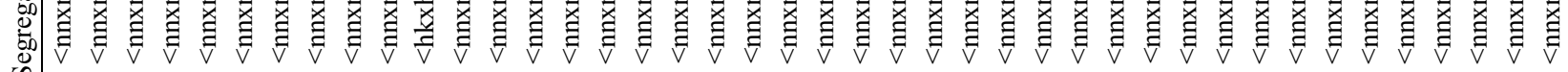
ڤ

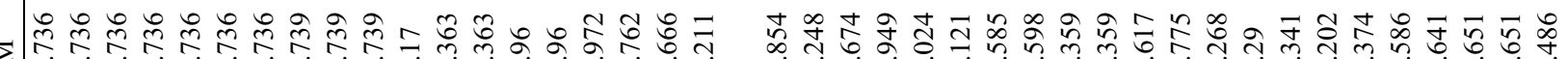
रे

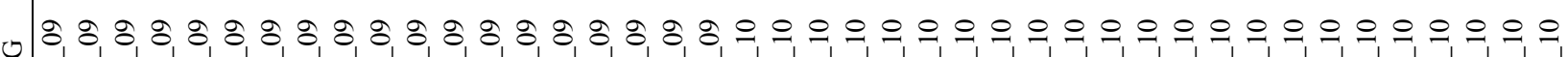
لَ

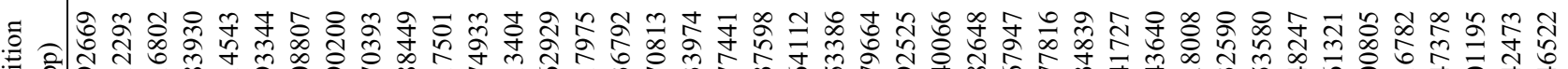

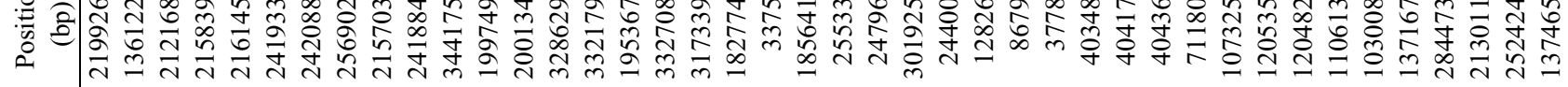

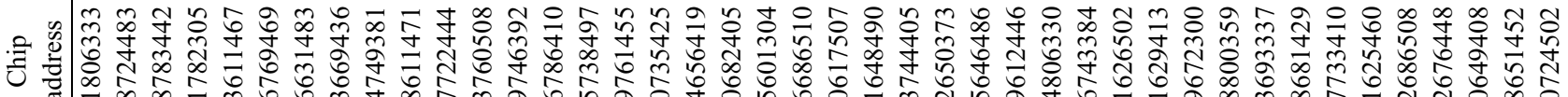

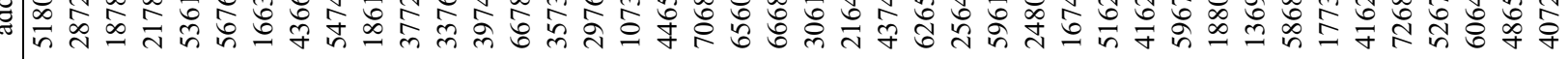

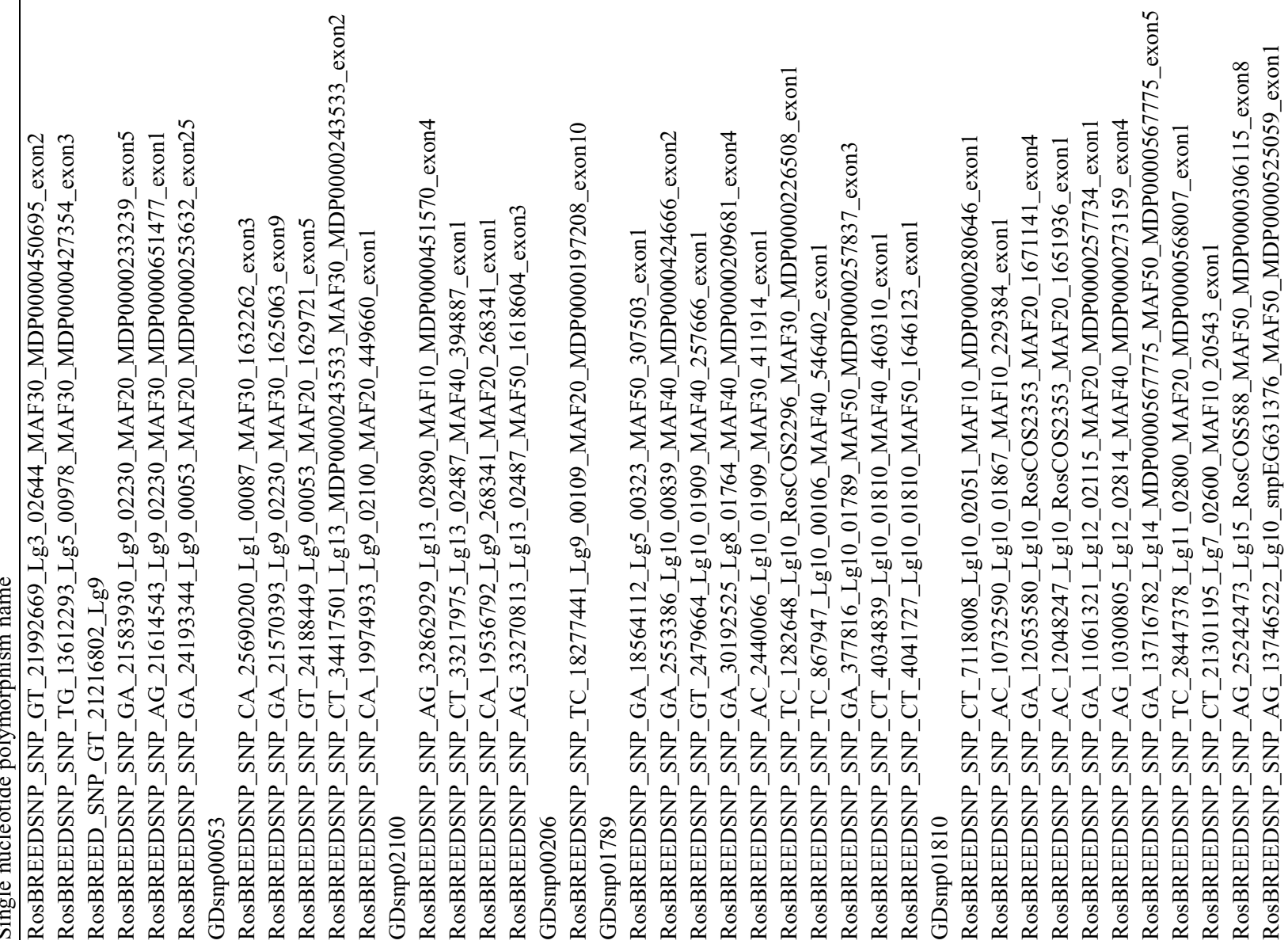




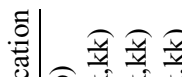

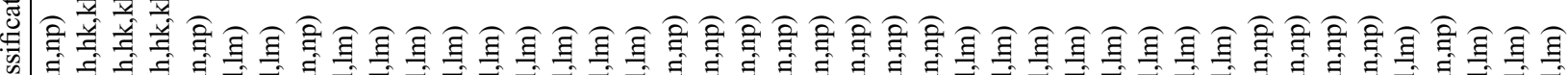

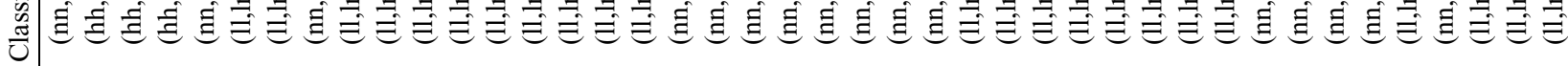

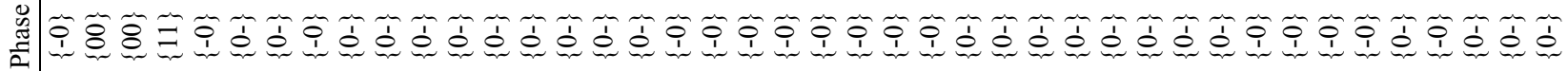

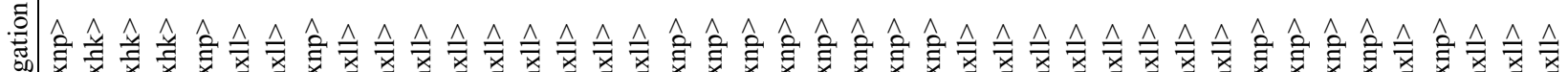
品 $\overbrace{}^{\infty}$

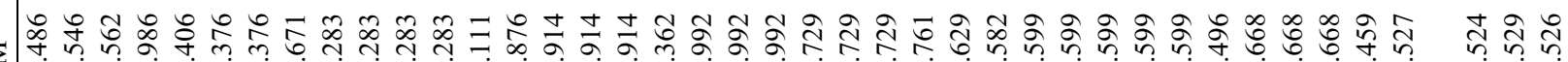

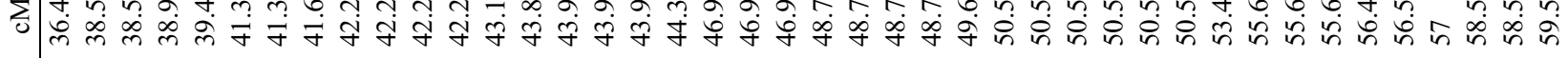

으으응ㅇㅇㅇㅇㅇㅇㅇㅇㅇㅇㅇㅇㅇㅇㅇㅇㅇㅇㅇㅇㅇㅇㅇㅇㅇㅇㅇㅇㅇㅇㅇㅇㅇㅇㅇㅇㅇㅇㅇㅇㅇㅇㅇㅇㅇㅇㅇㅡ

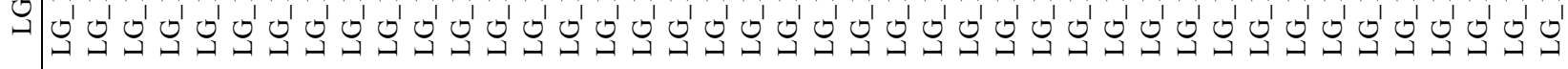

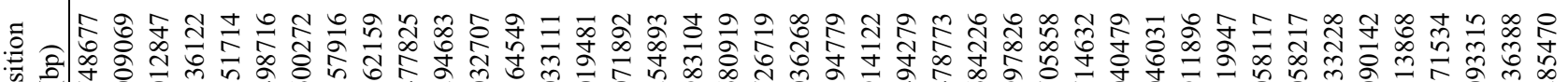

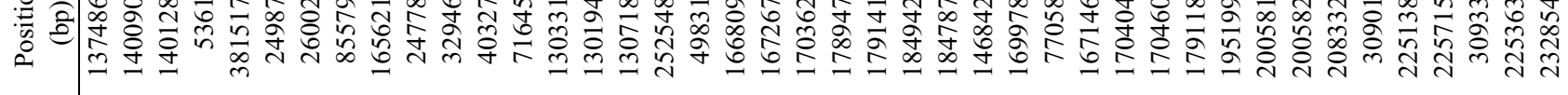
:

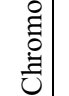

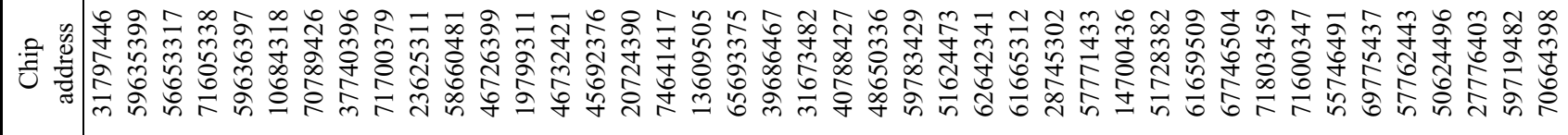

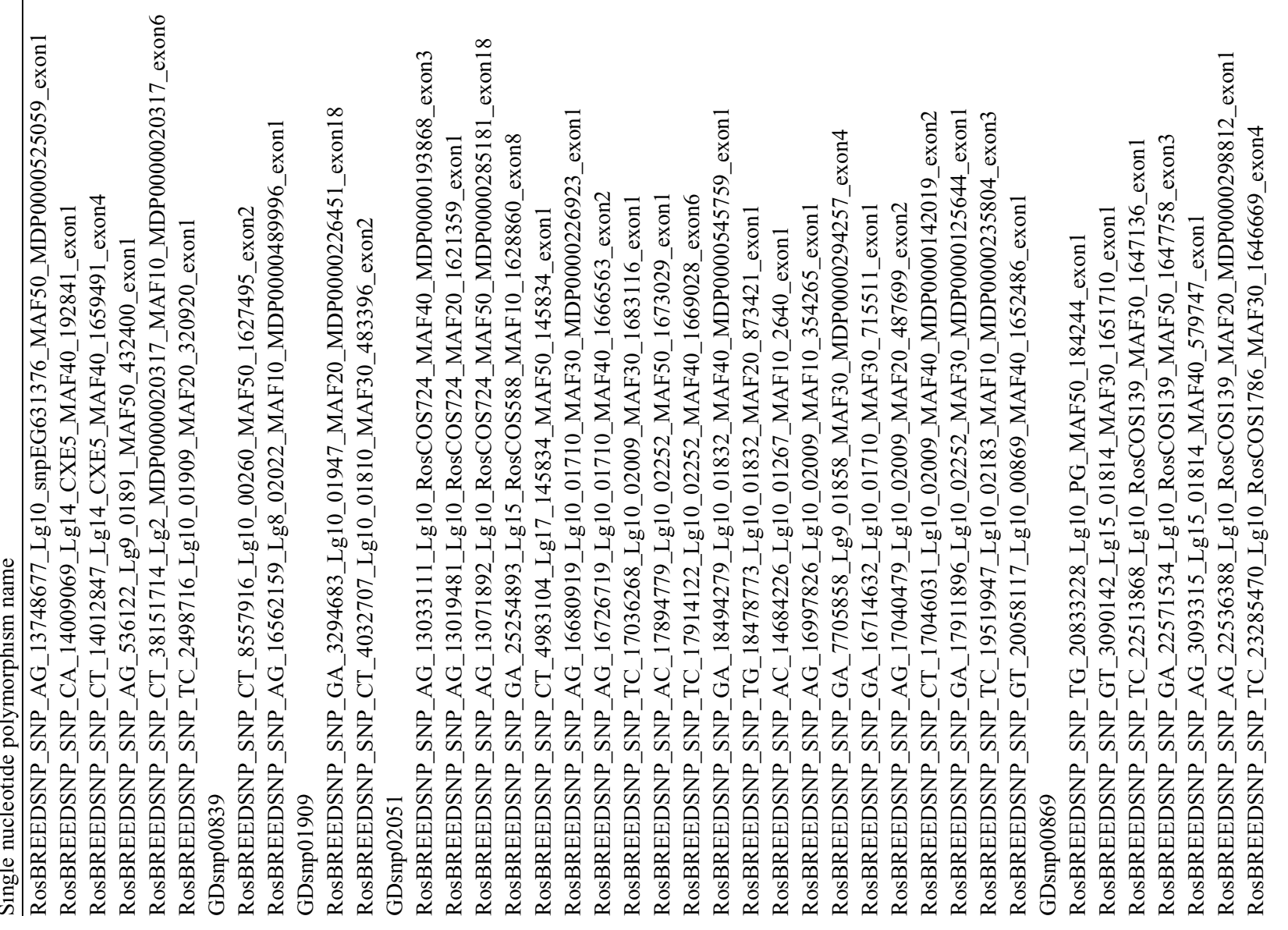




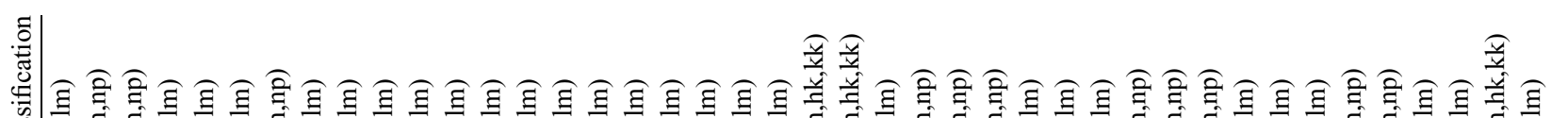

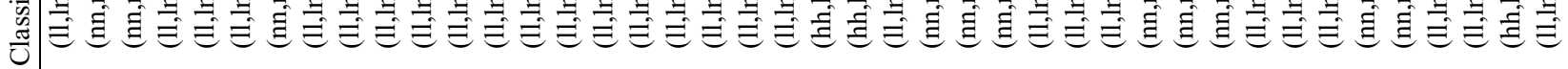

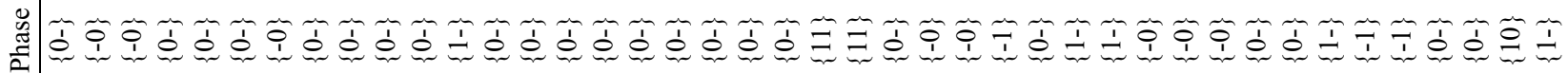

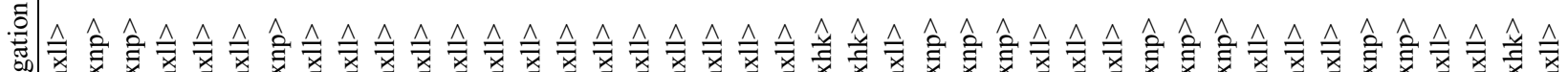

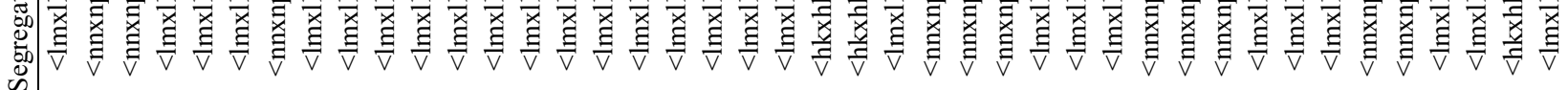

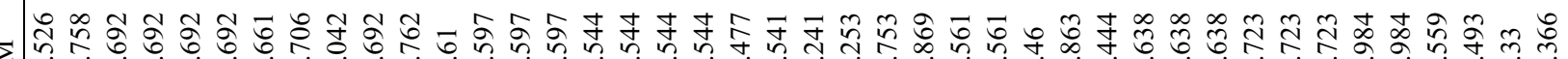

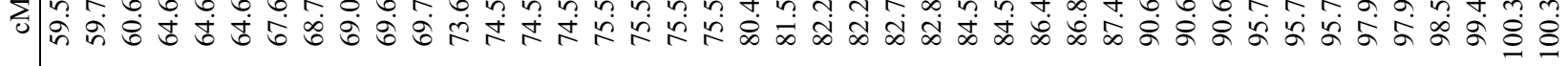
응ㅇ으으으으으으으으으으으으으으으으으으으으으으으으으느

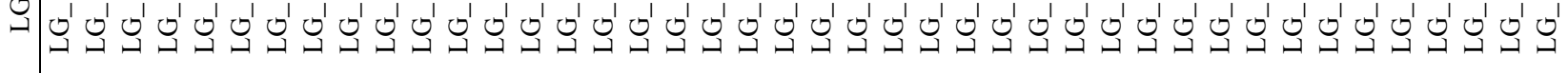

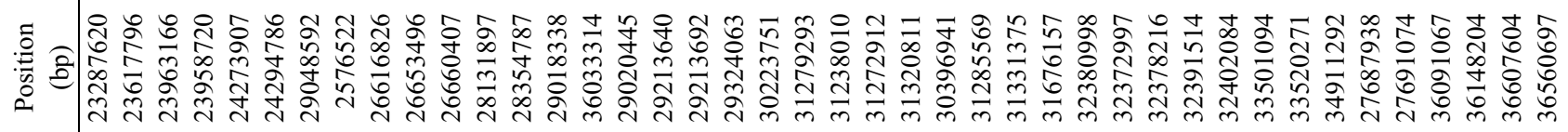
: 离

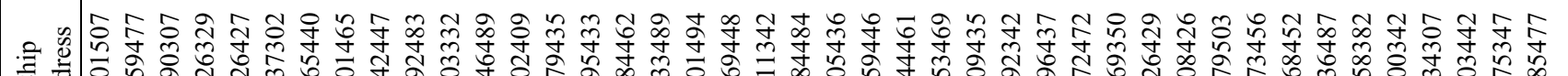

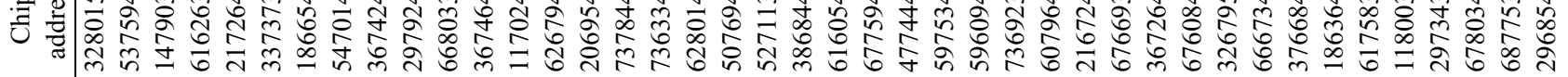

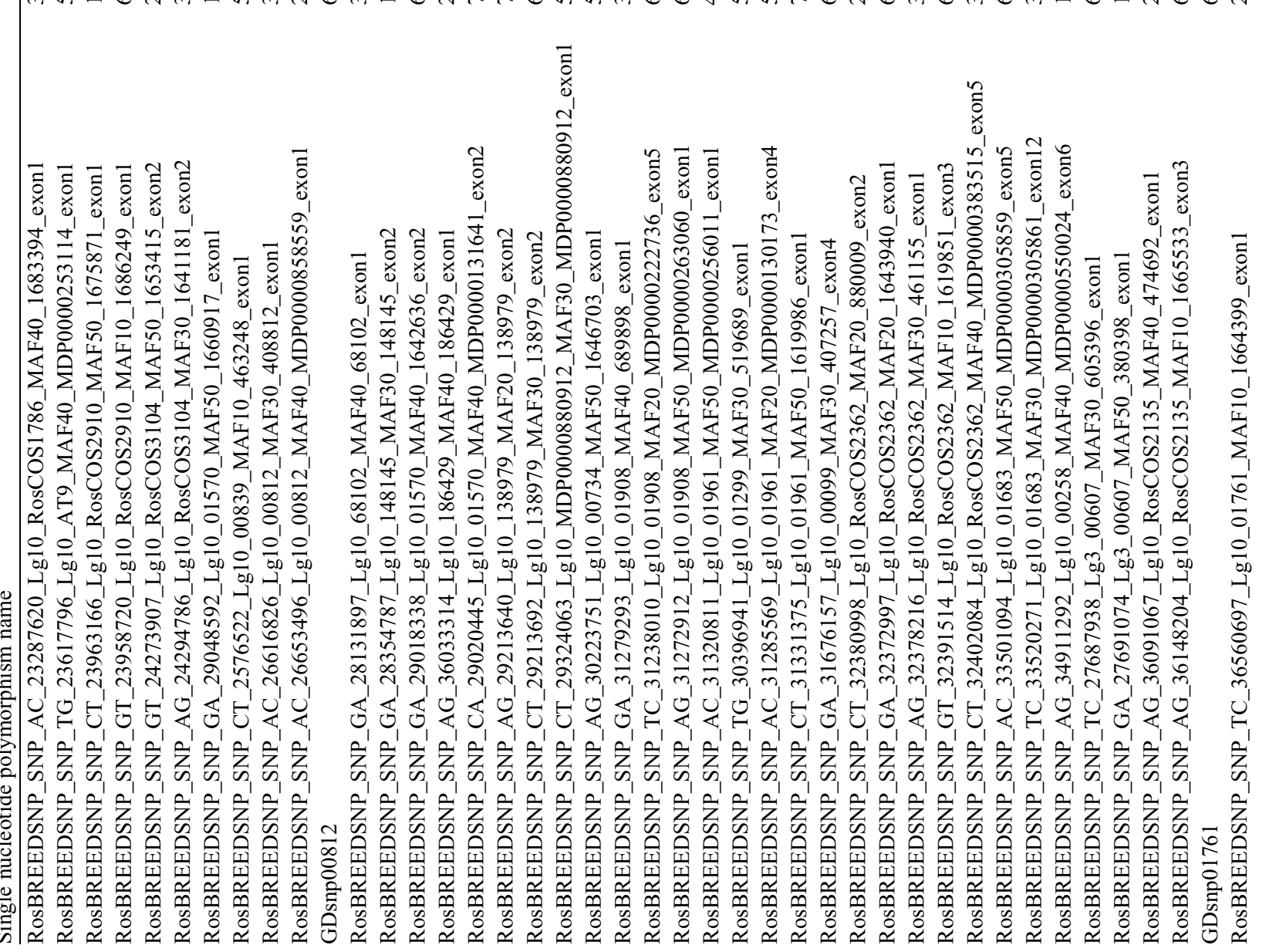




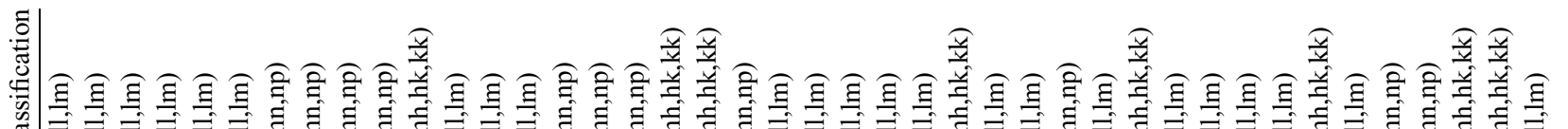

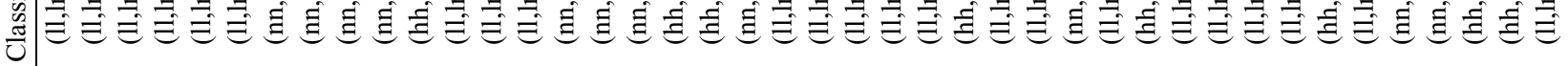

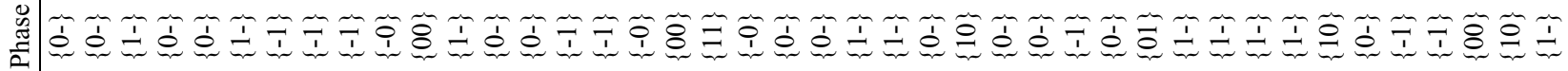

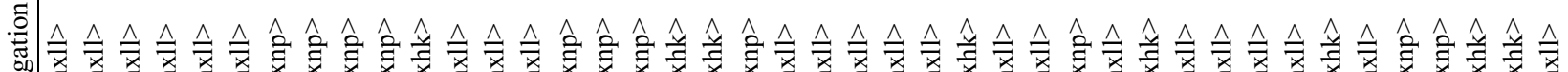

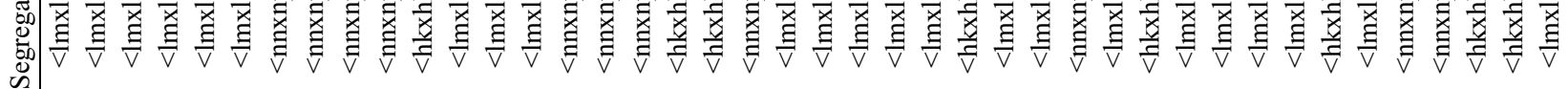
s

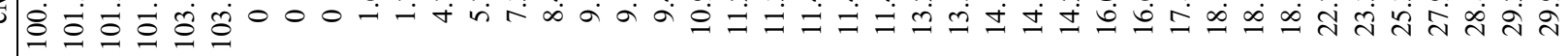

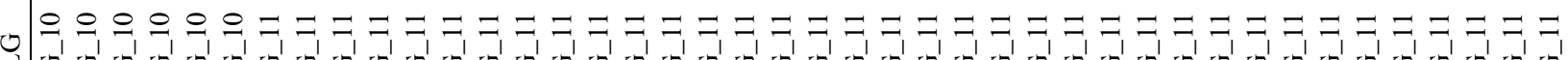
- ن

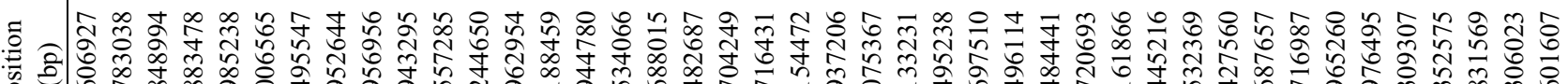

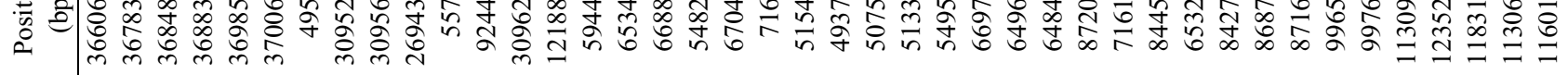

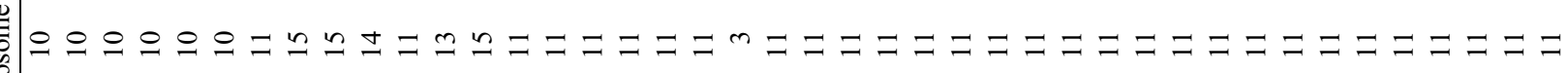
豙

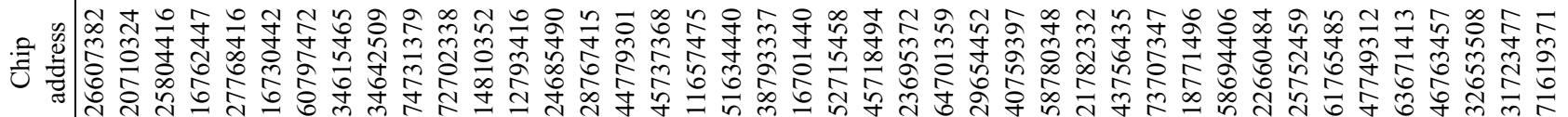

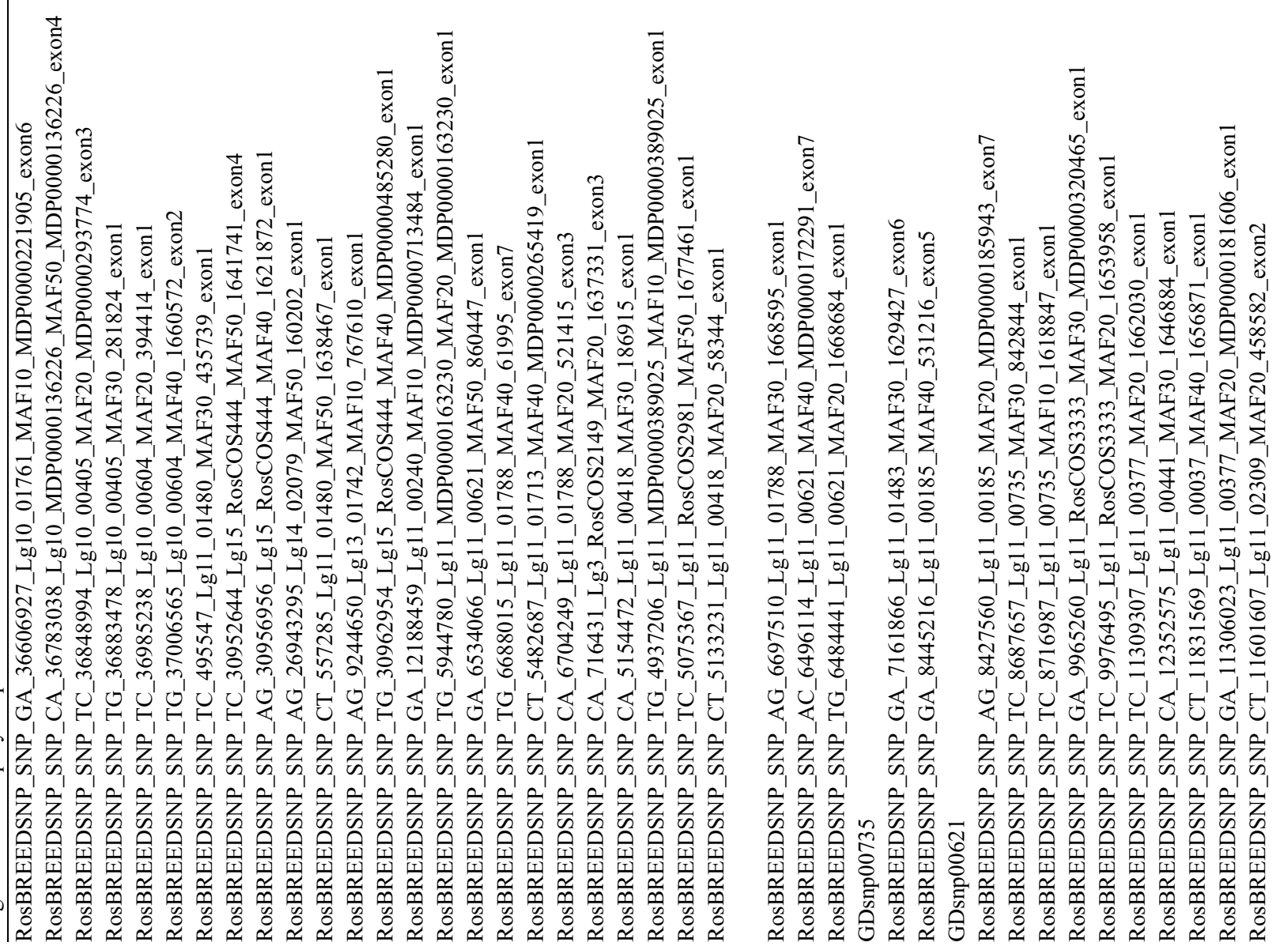




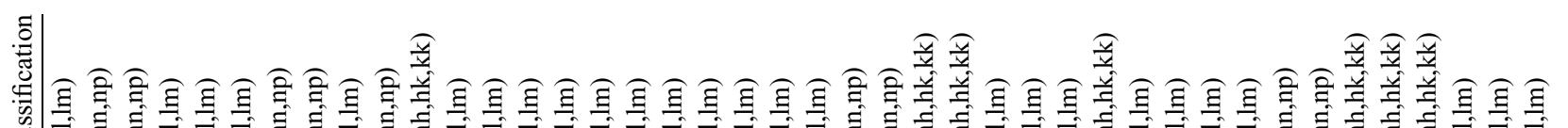

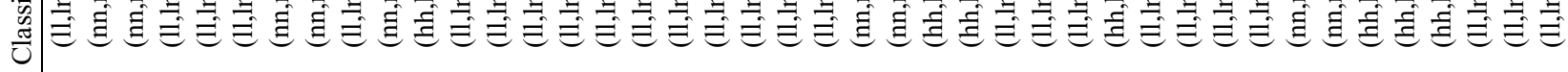

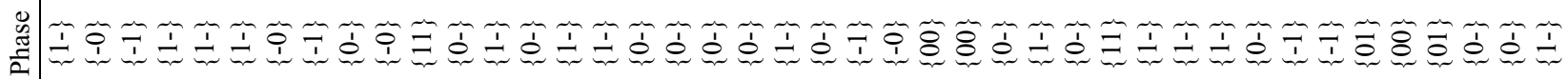

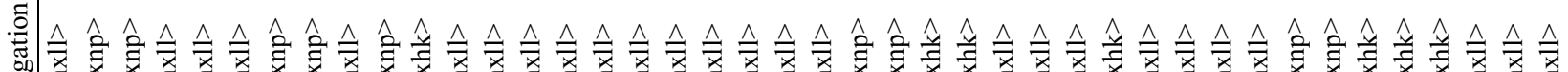

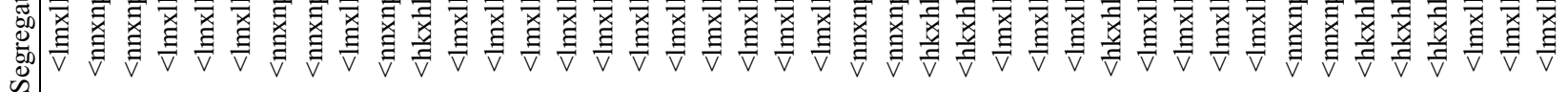

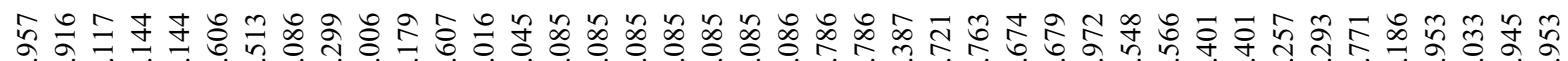

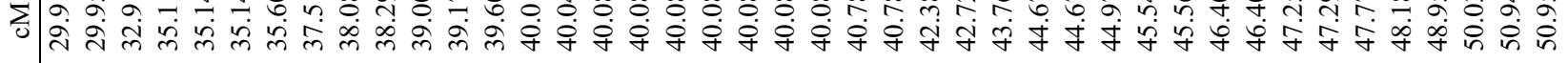

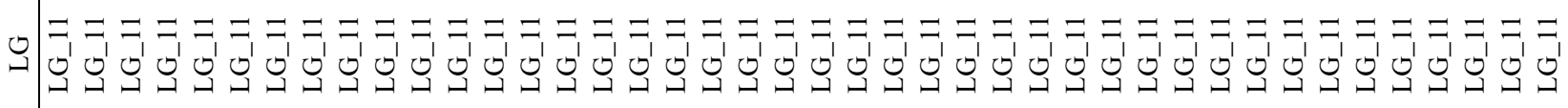

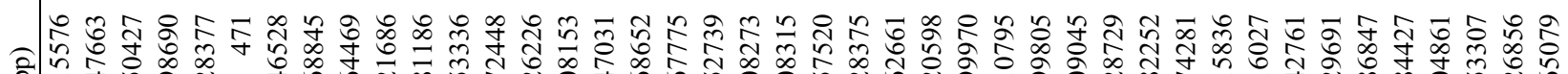

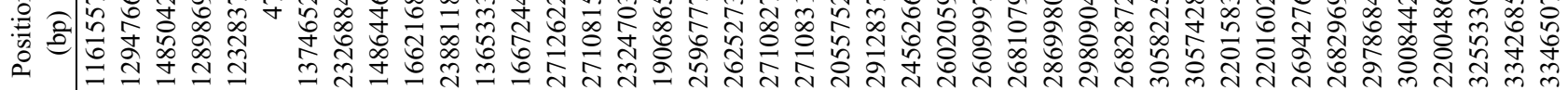

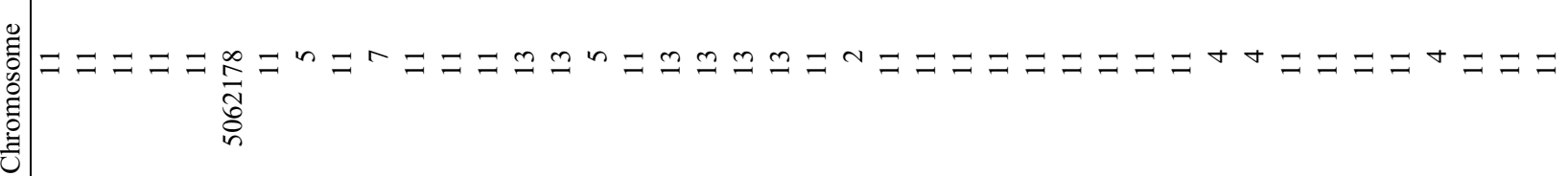

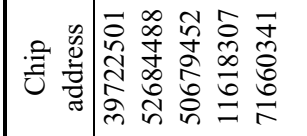

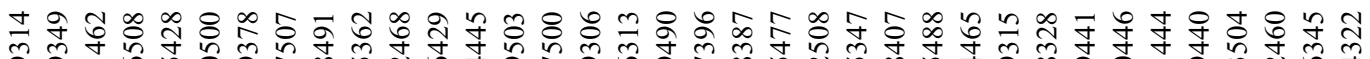

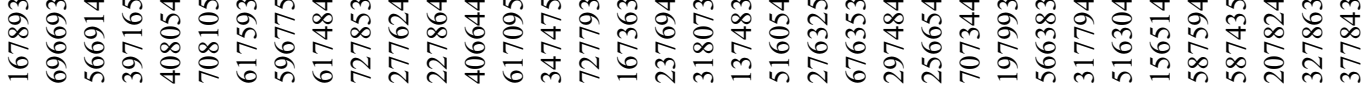

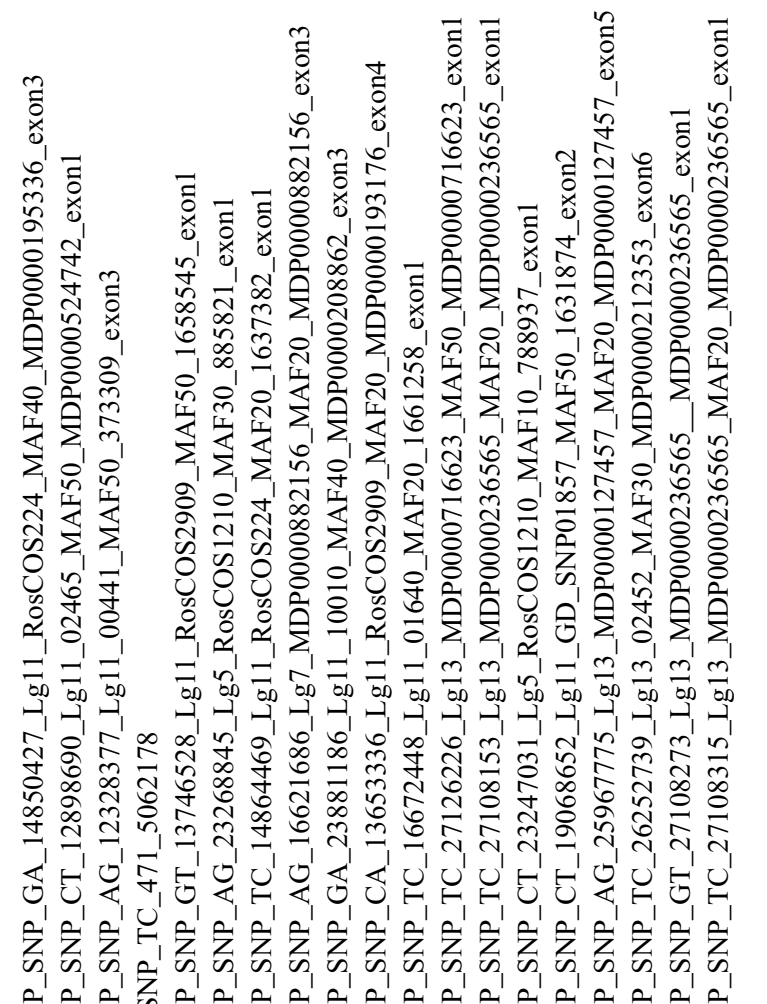

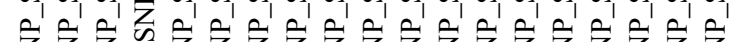
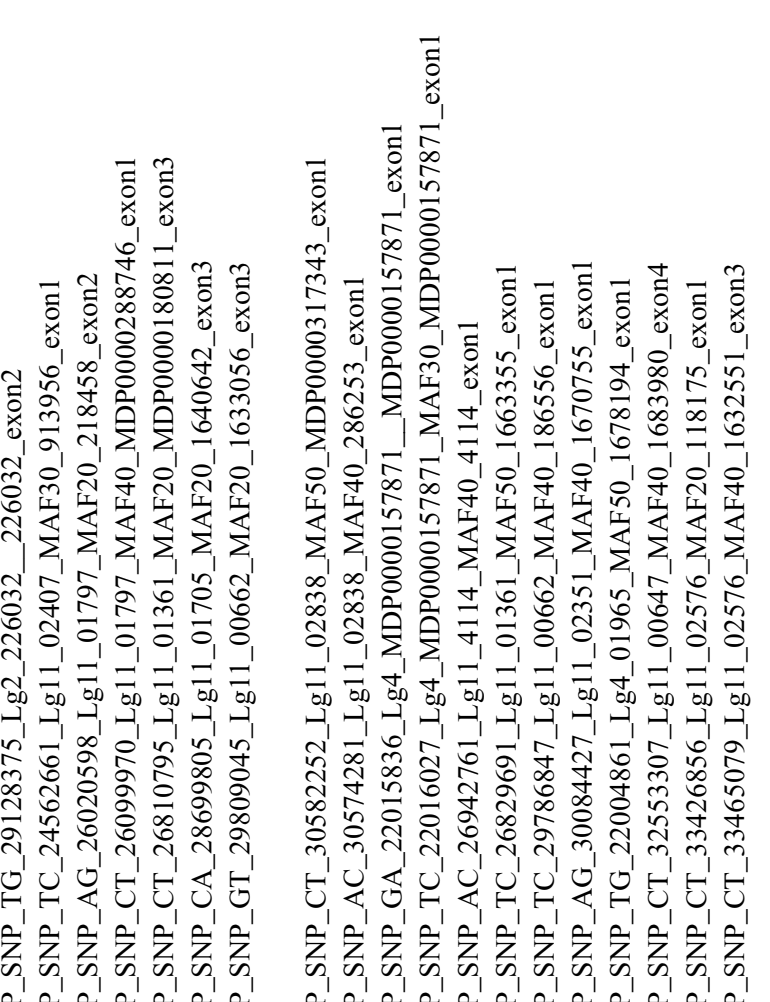

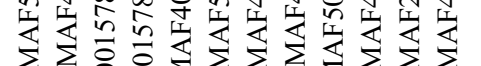

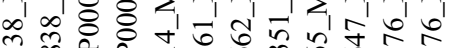
命

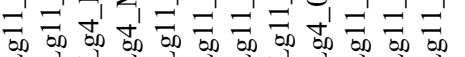
(1) సळ. त प 文

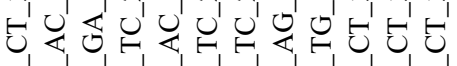

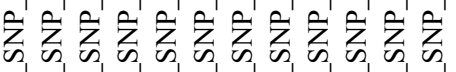

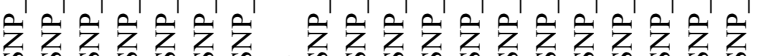
ơ

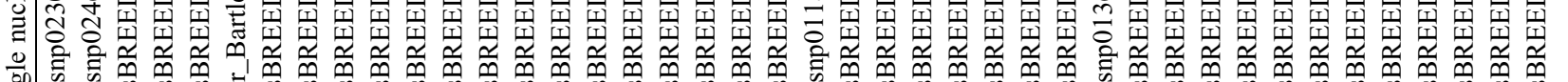
जी 


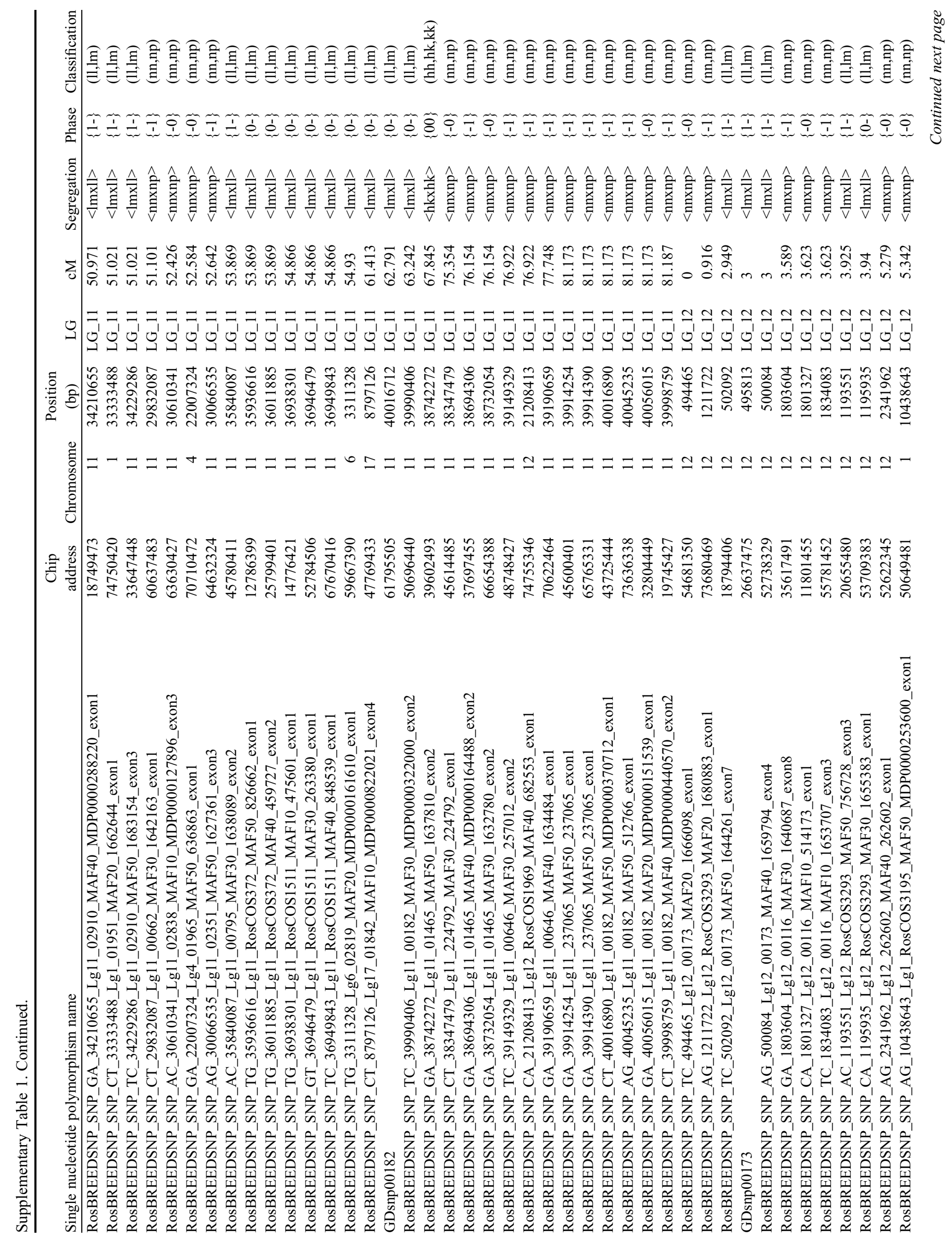




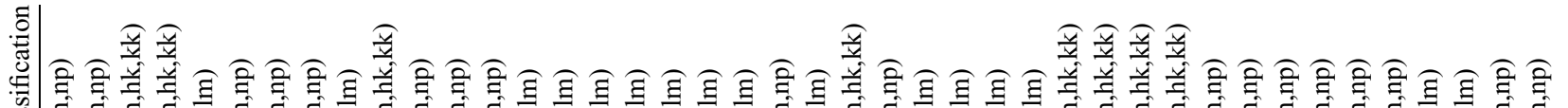

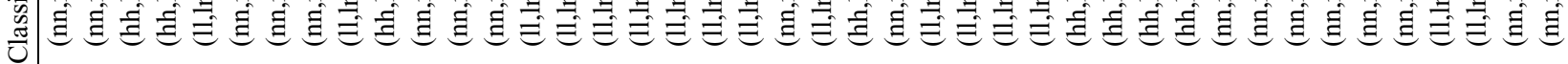

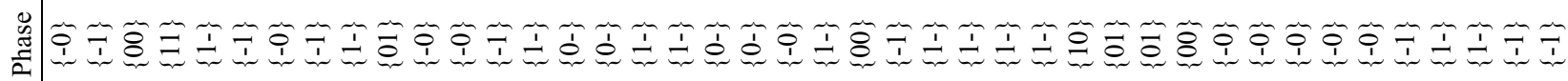

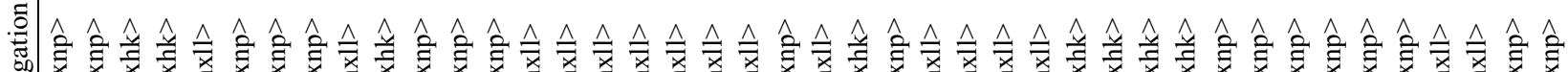

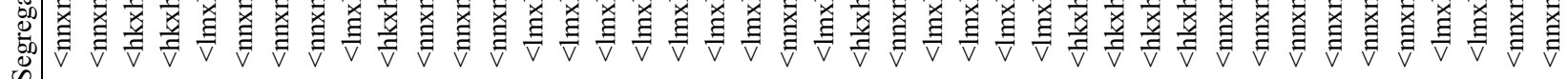

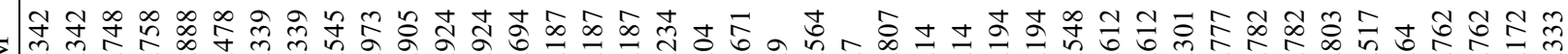

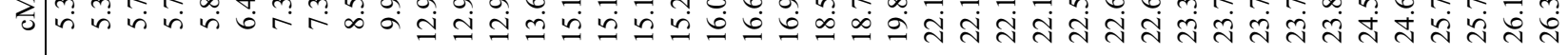

$0 \simeq \simeq \simeq \simeq \simeq \simeq \simeq \simeq \simeq \simeq \simeq \simeq \simeq \simeq \simeq \simeq \simeq \simeq \simeq \simeq \simeq \simeq \simeq \simeq \simeq \simeq \simeq \simeq \simeq \simeq \simeq \simeq \simeq \simeq \simeq \simeq \simeq \simeq \simeq \simeq \simeq$

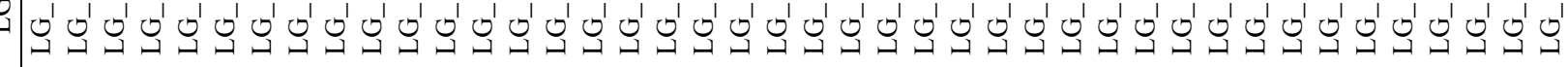

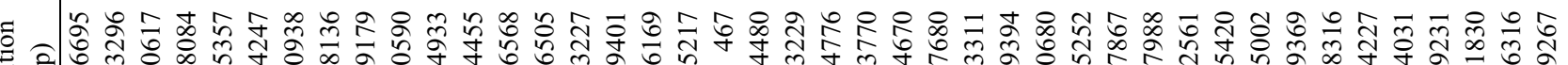

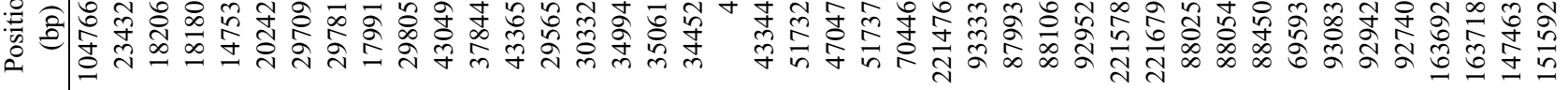

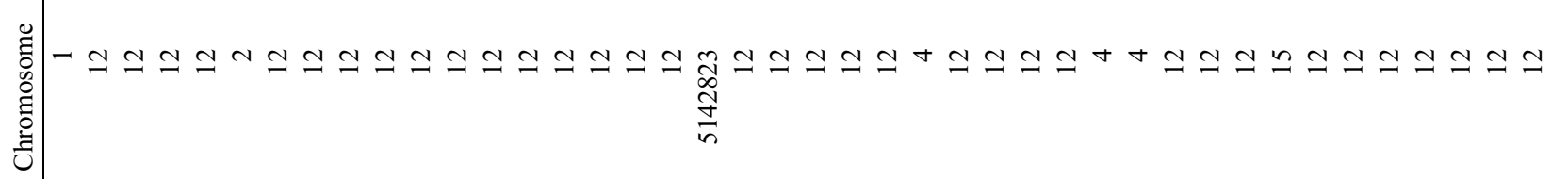

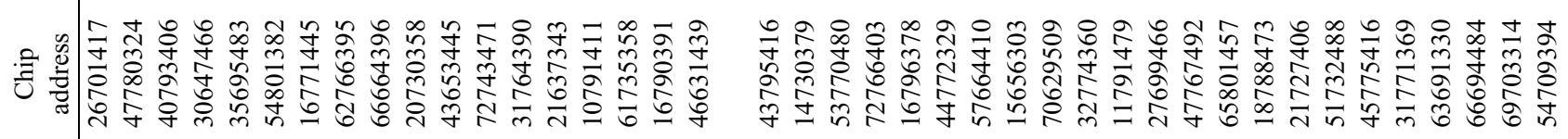

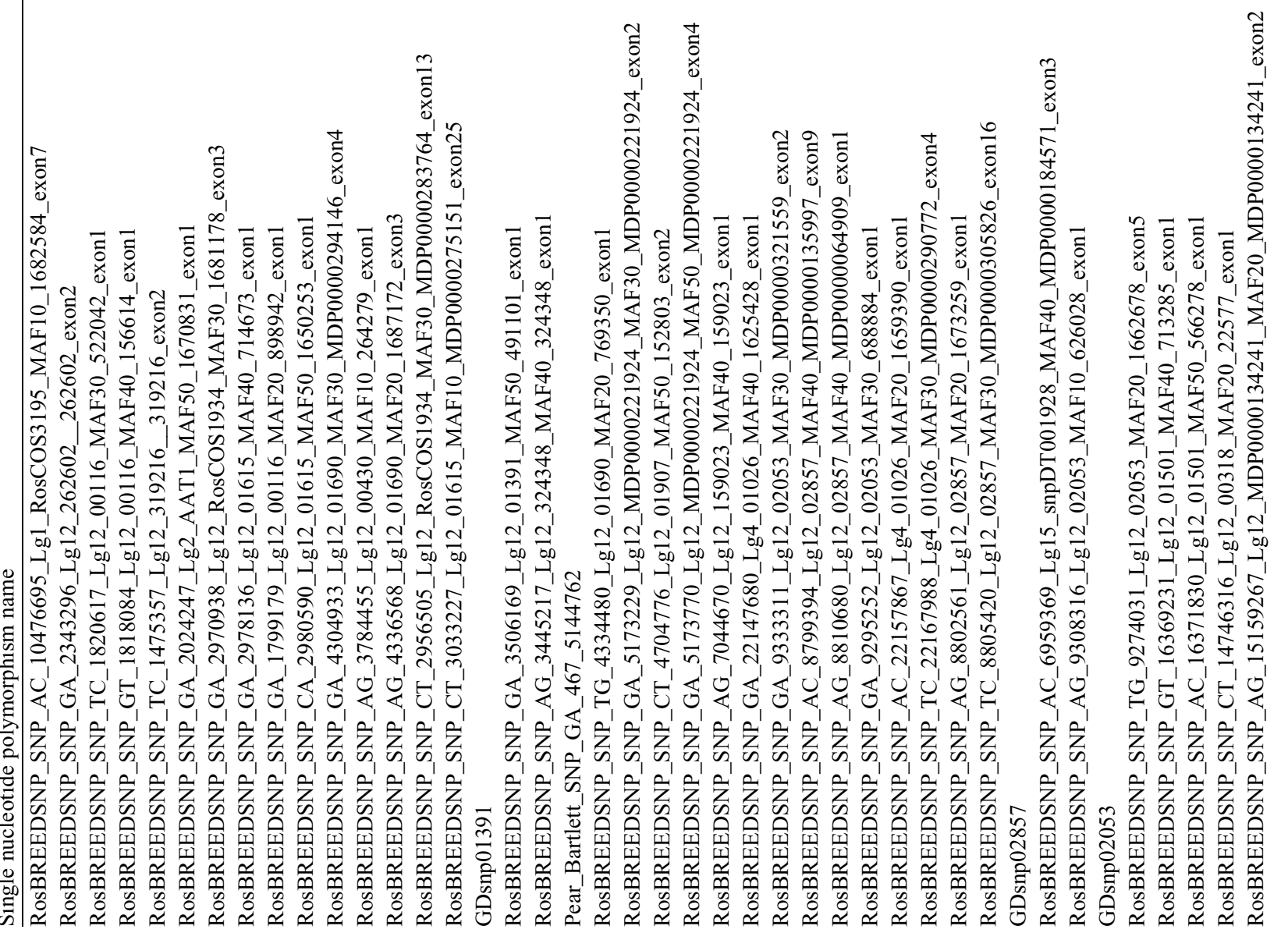




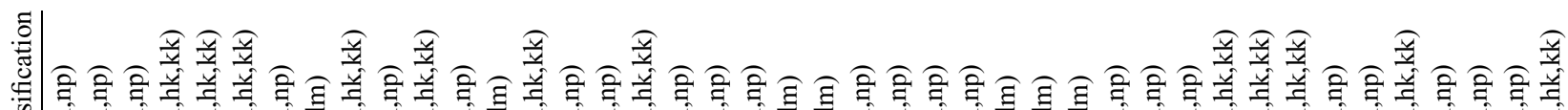

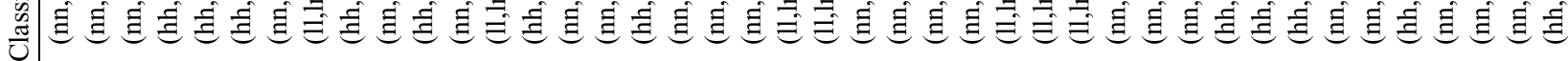

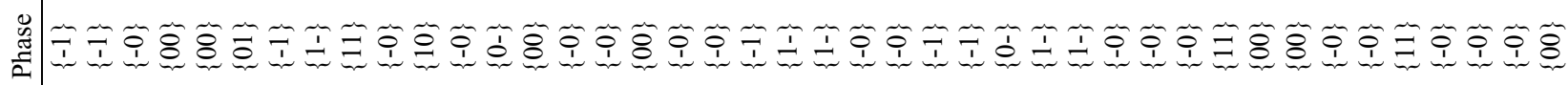

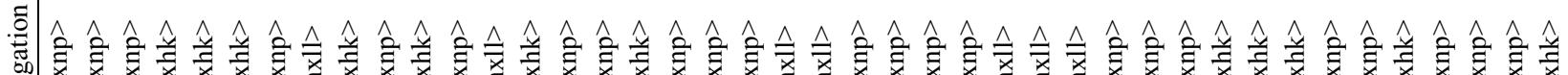

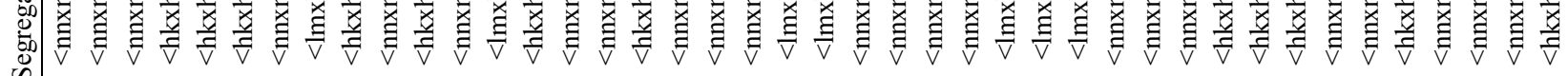

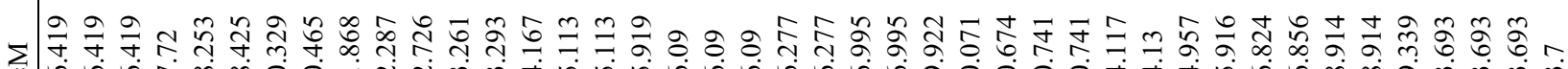

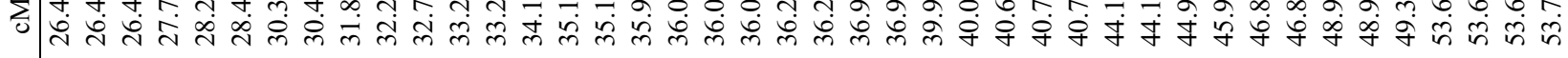
$0 \simeq \simeq \simeq \simeq \simeq \simeq \simeq \simeq \simeq \simeq \simeq \simeq \simeq \simeq \simeq \simeq \simeq \simeq \simeq \simeq \simeq \simeq \simeq \simeq \simeq \simeq \simeq \simeq \simeq \simeq \simeq \simeq \simeq \simeq \simeq \simeq \simeq \simeq \simeq \simeq \simeq \simeq$ - no

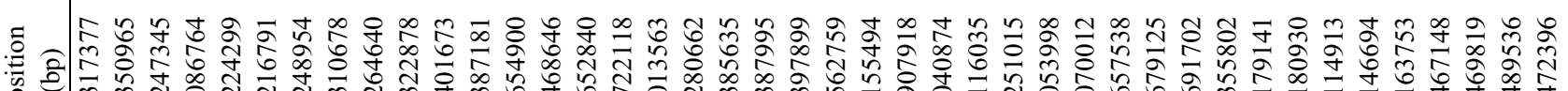

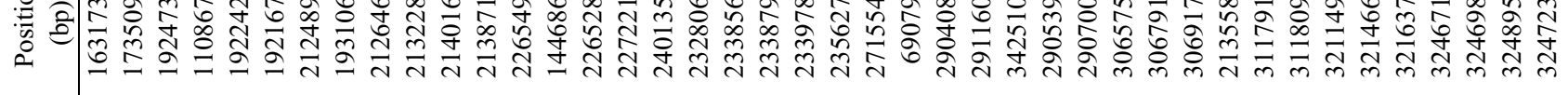
일

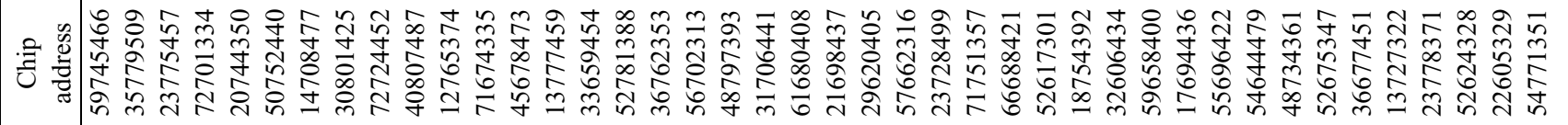

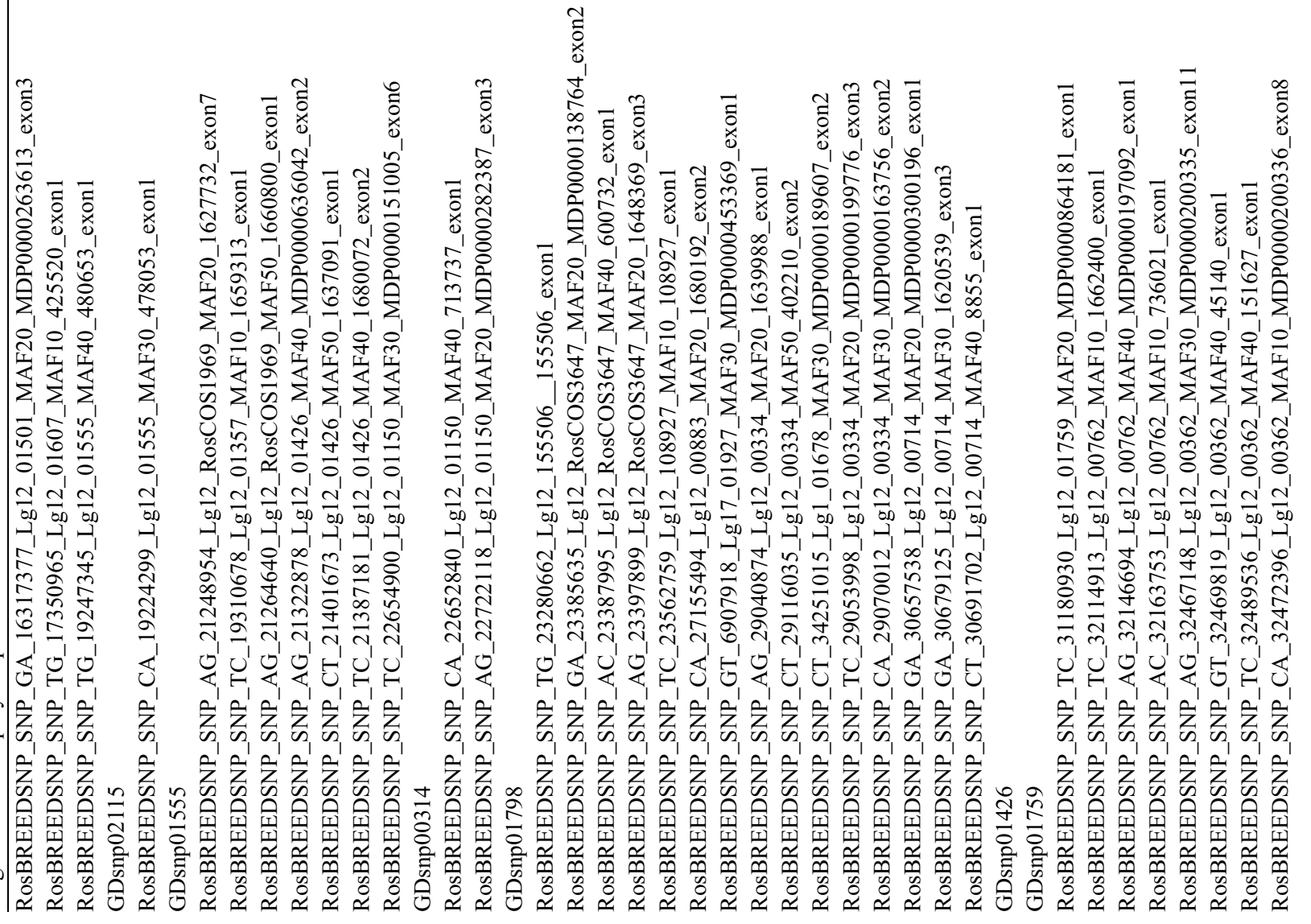




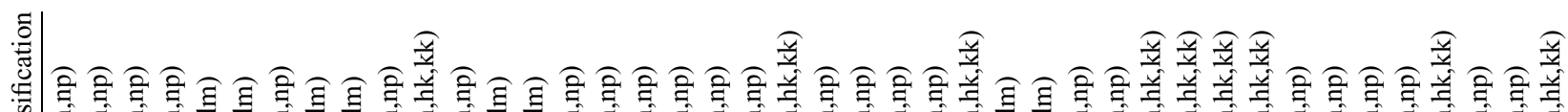

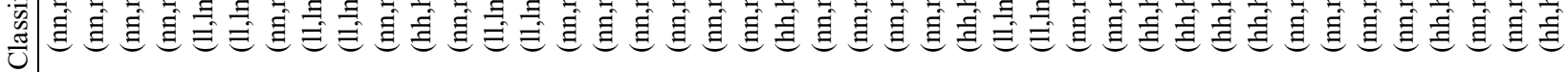

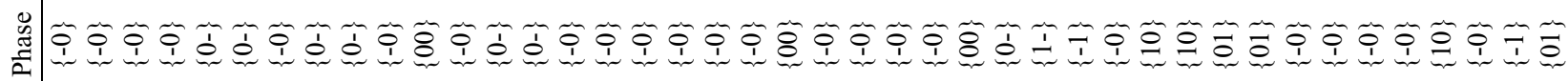

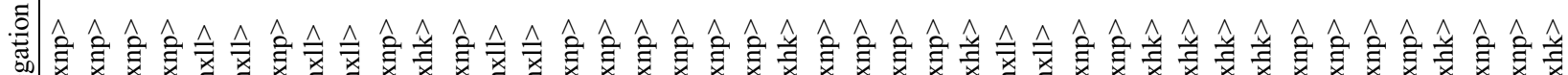

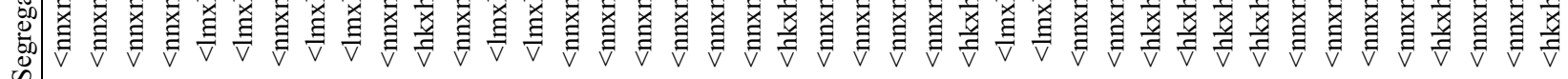
ڤँ

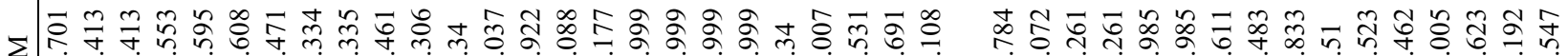

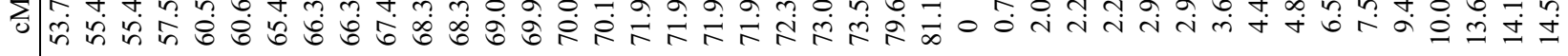

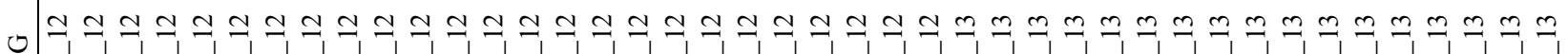
أق

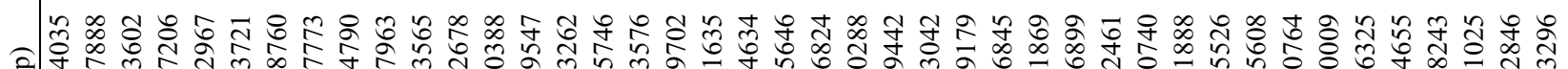

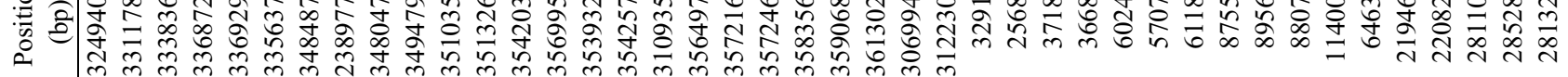
छั

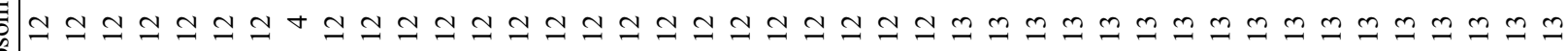
ปี่

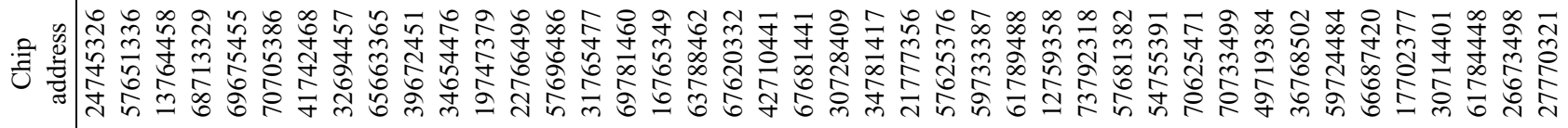

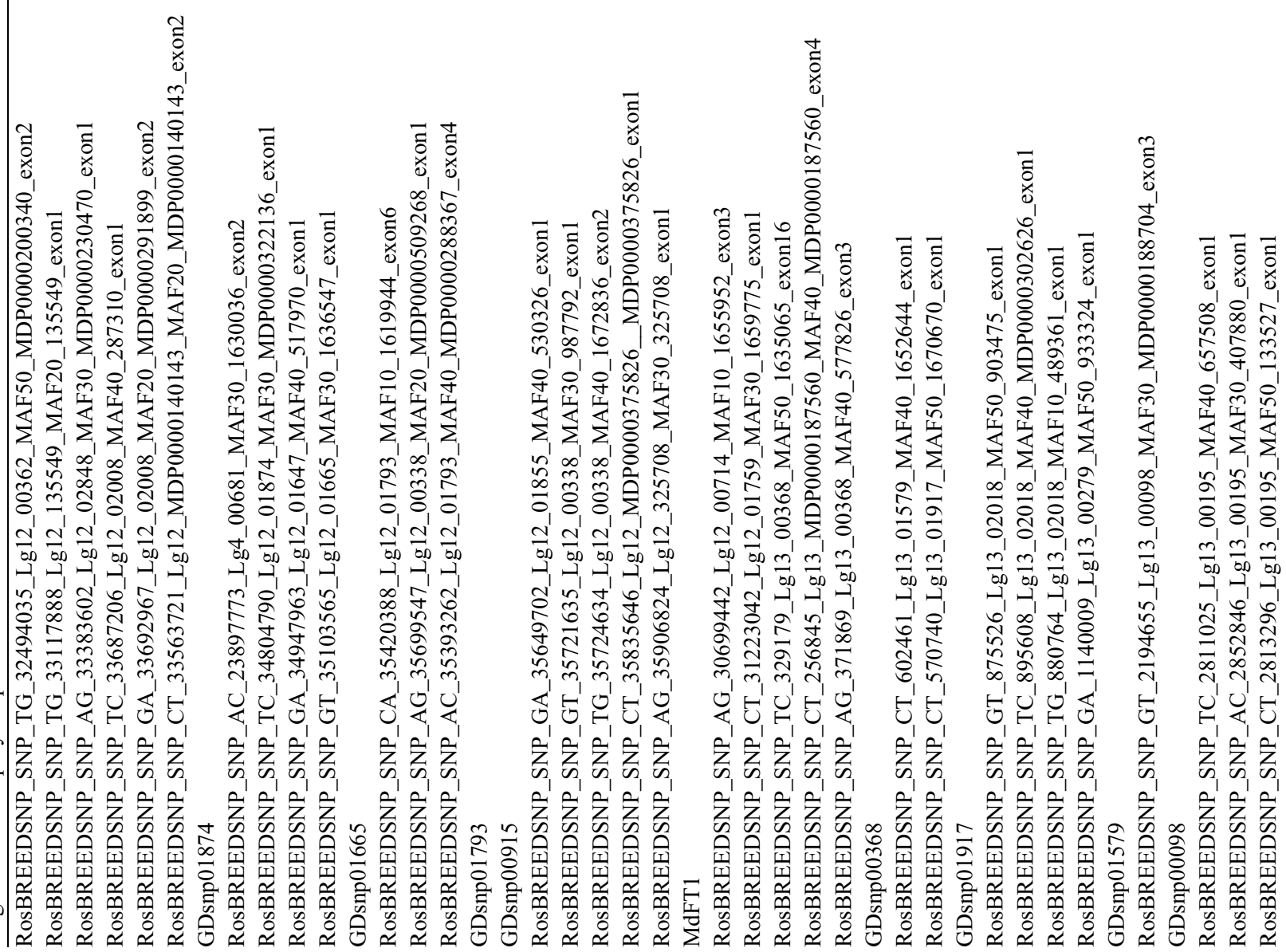




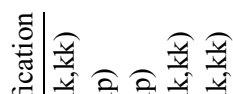

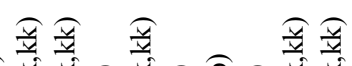

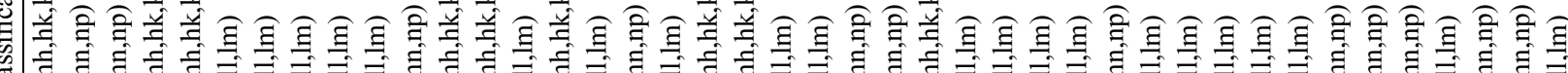

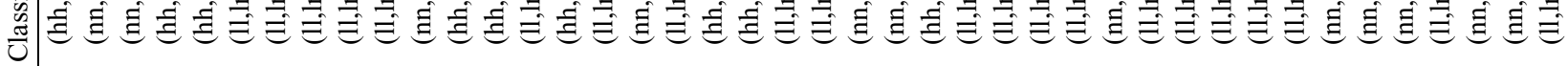

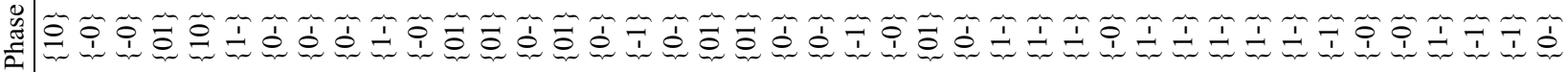

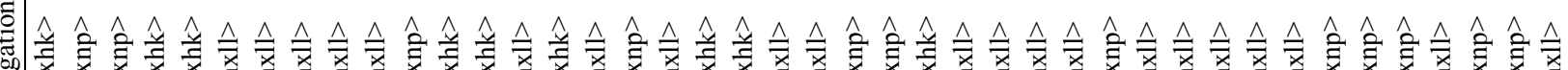

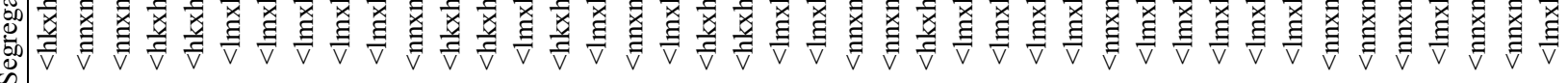

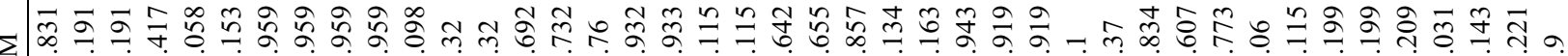

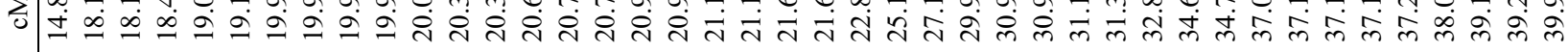

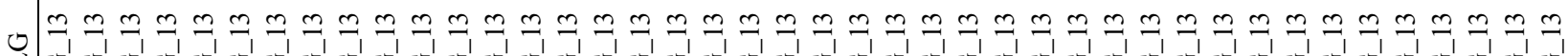

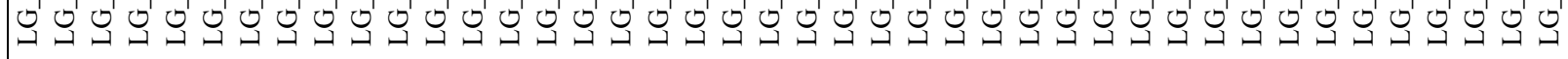

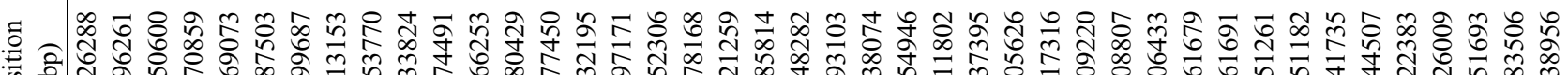
管

:

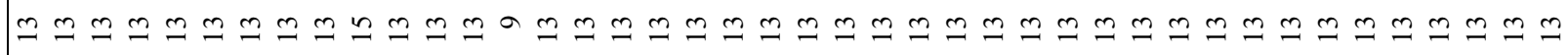
己ี

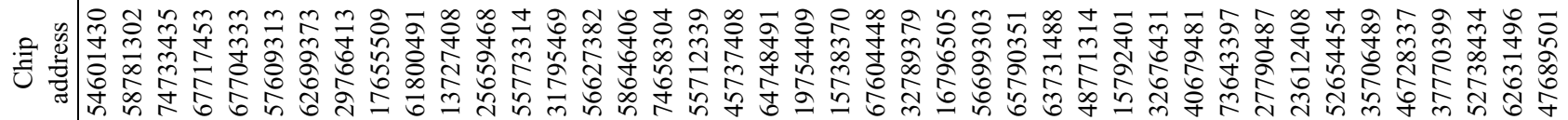

$\overline{\text { हี }}$ है

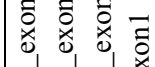

กิ่

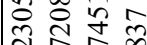

त్రీ

तิ 윙ำ

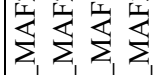

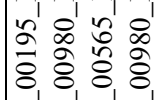

mo $\frac{m}{60} \frac{m}{b 0} \frac{m}{b 0}$

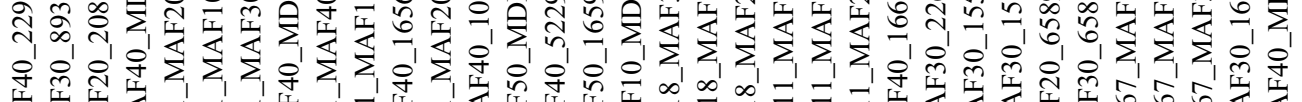

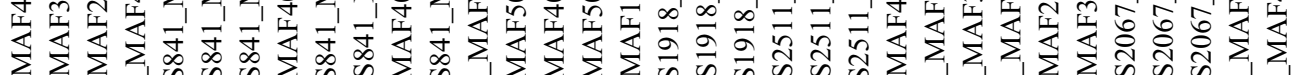

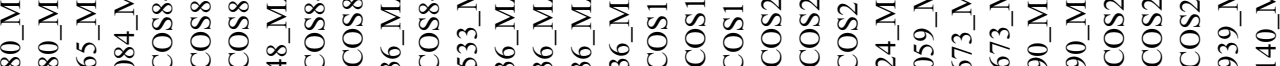

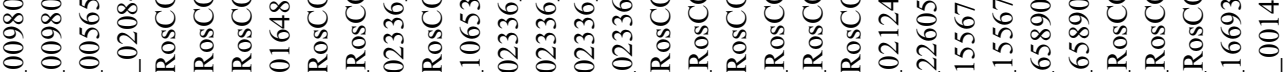

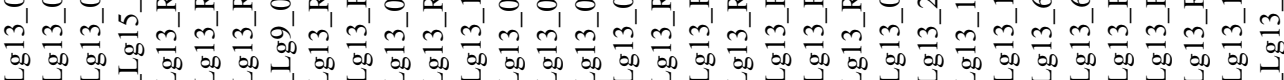

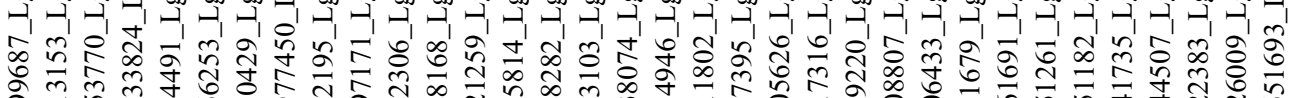

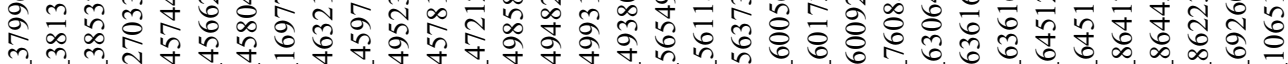

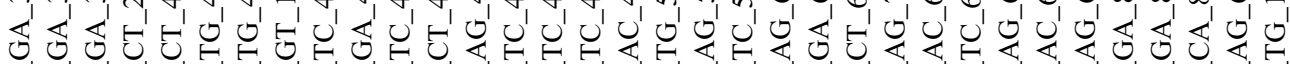

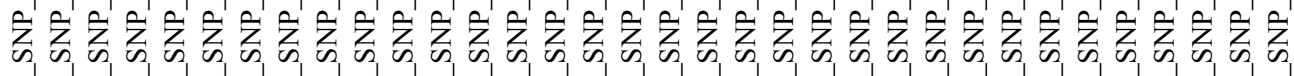




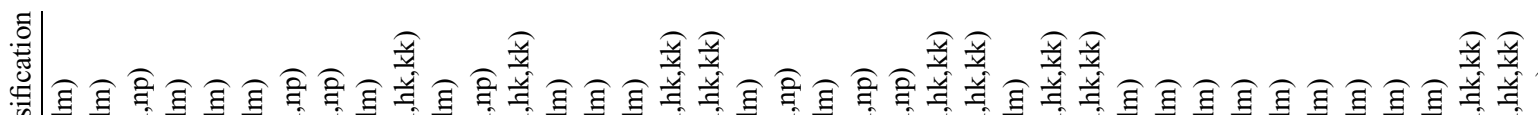

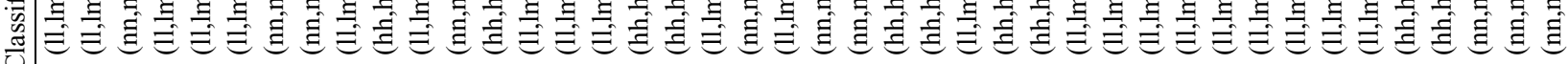
(1)

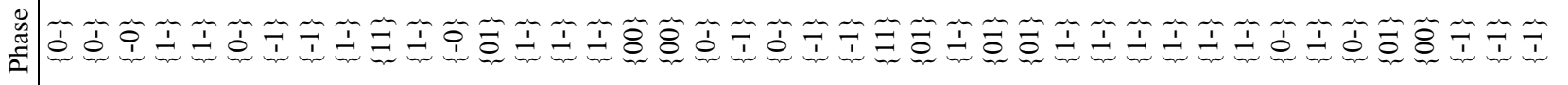

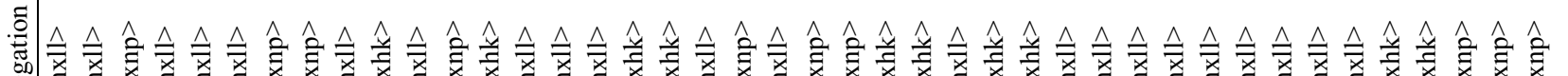
尊

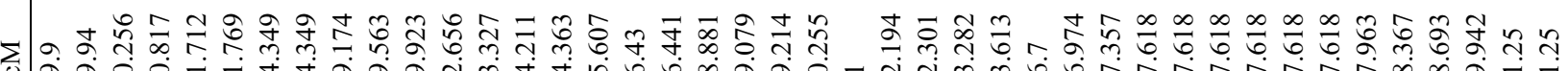

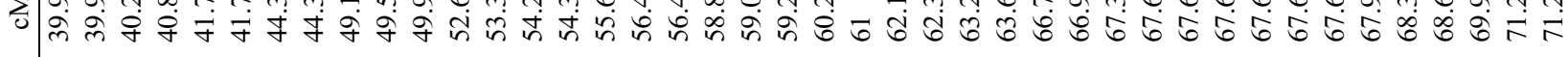

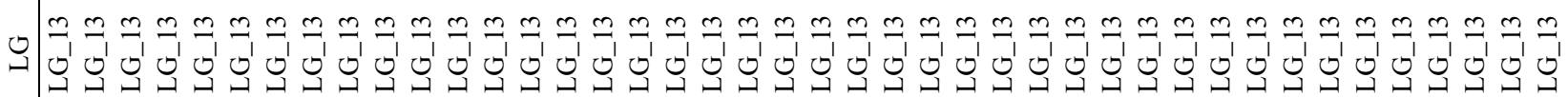

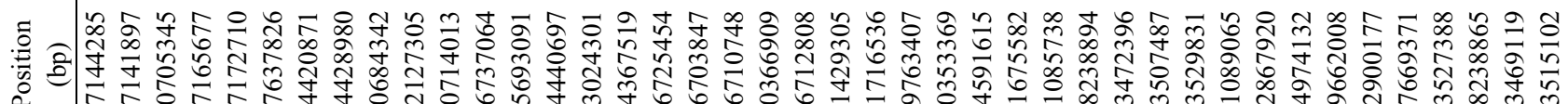
范

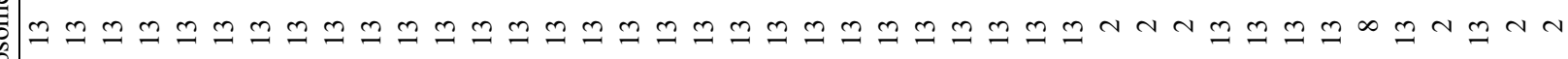

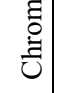

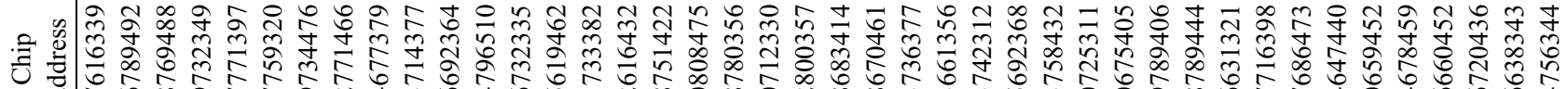

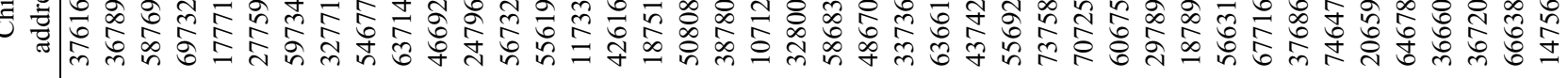

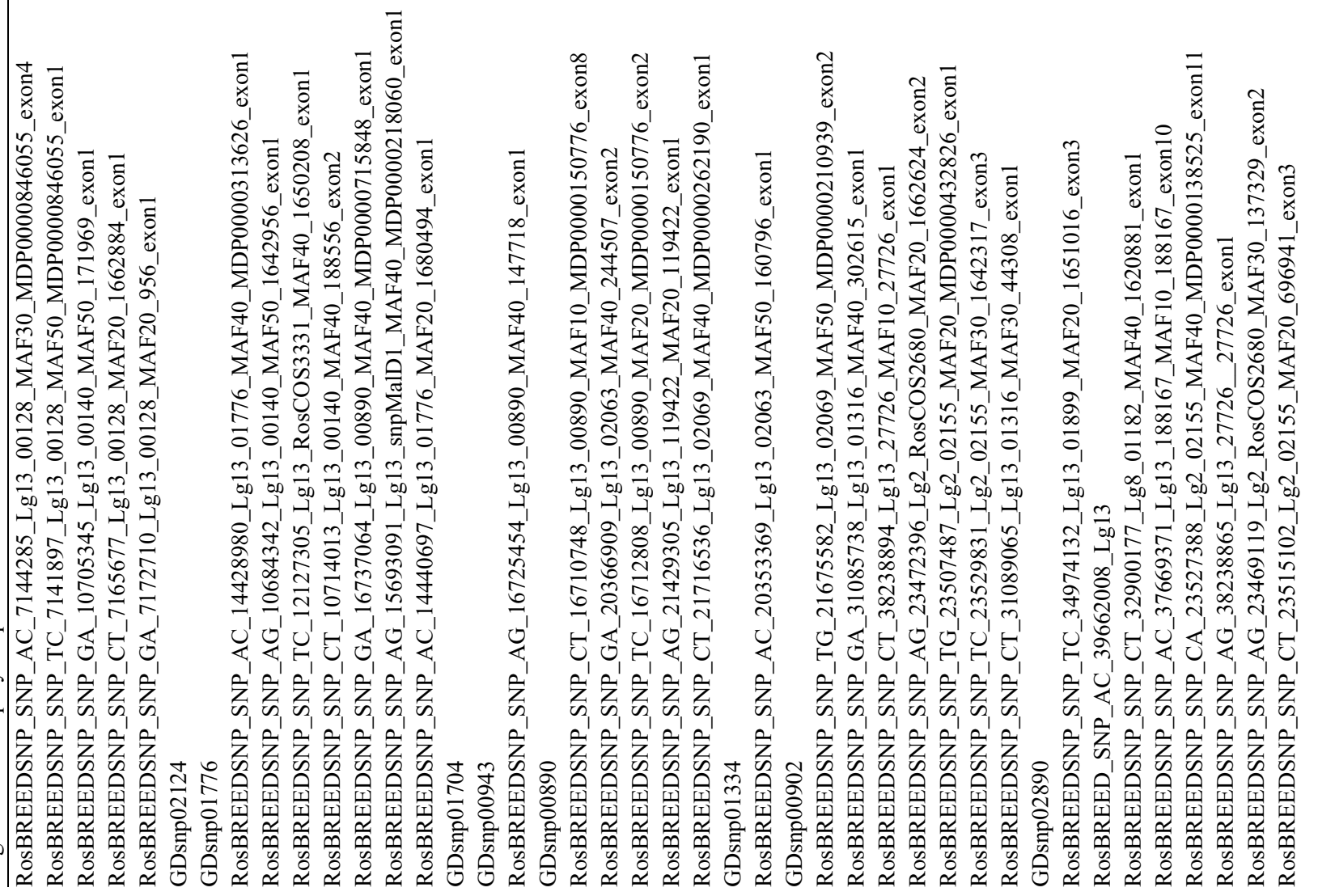




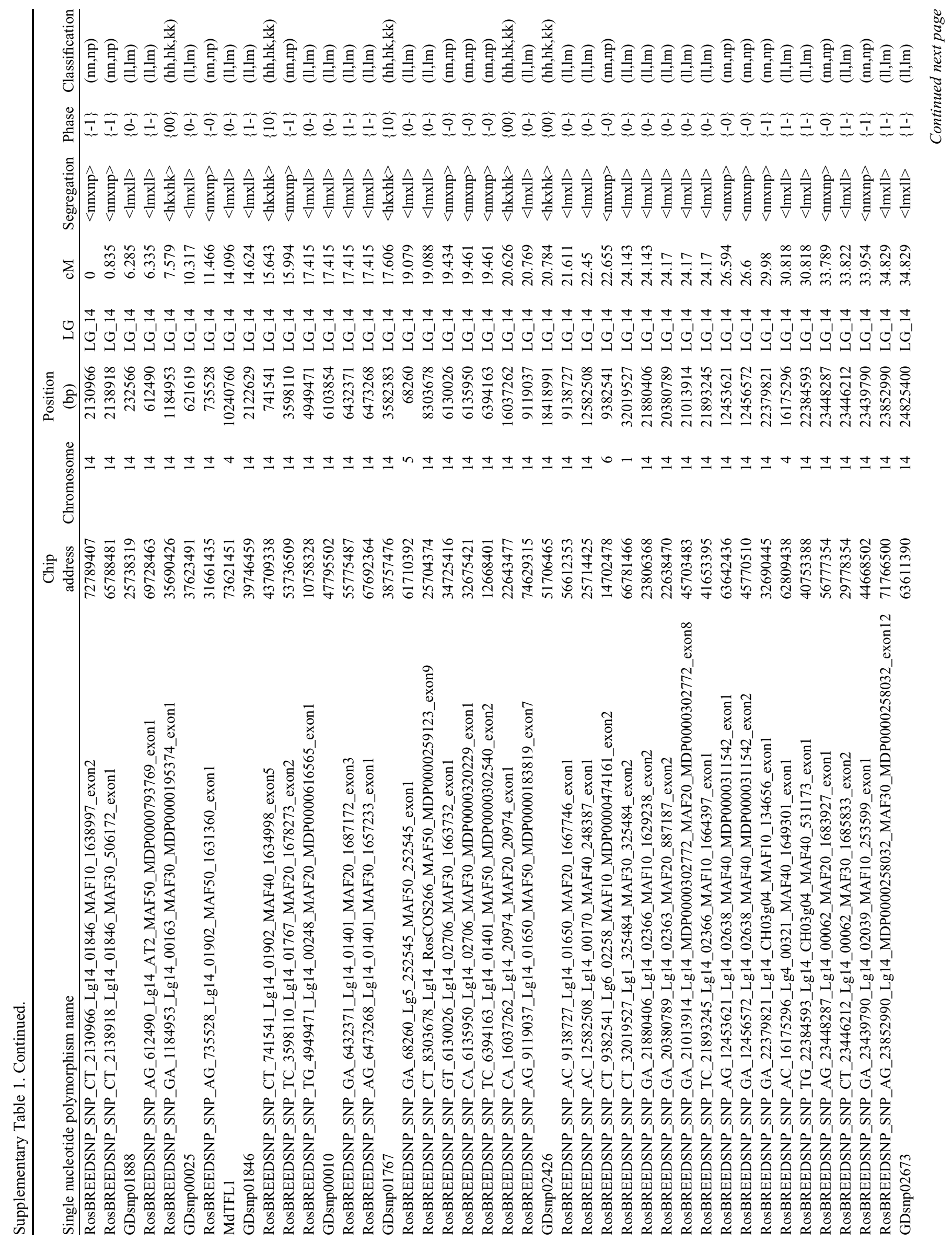




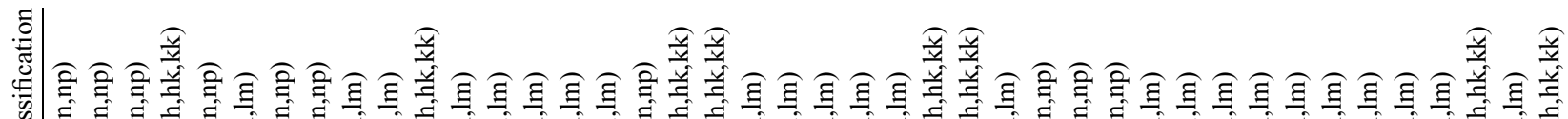

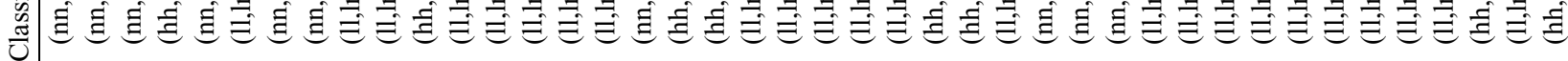

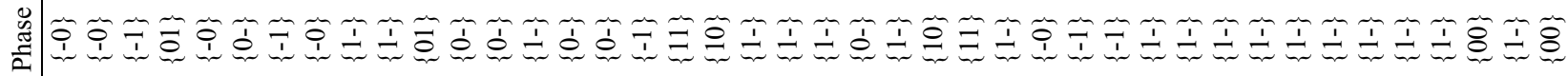

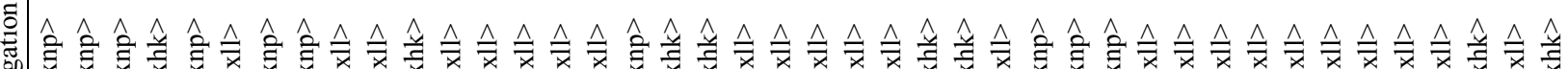

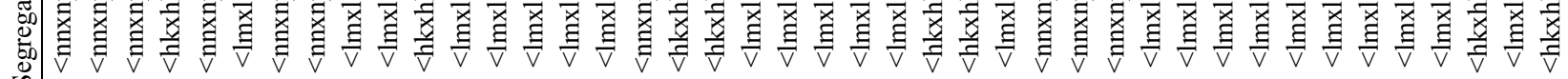
œ

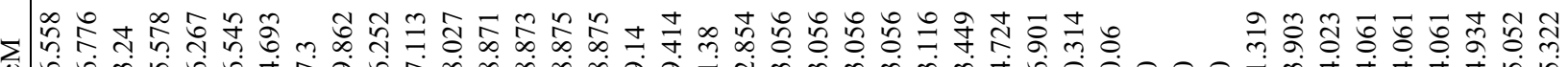

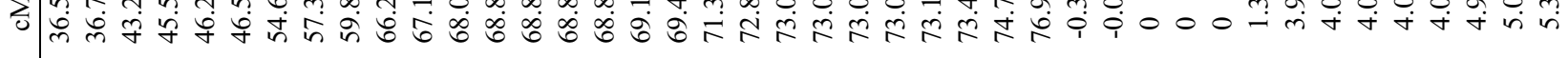

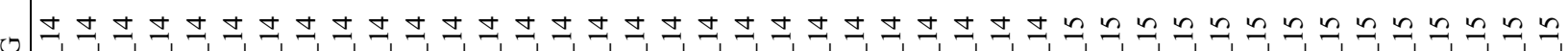

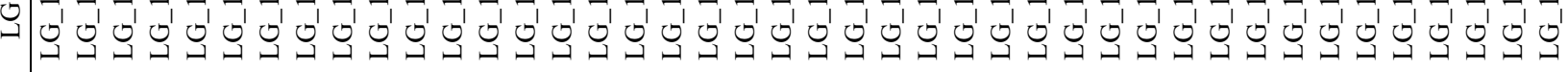

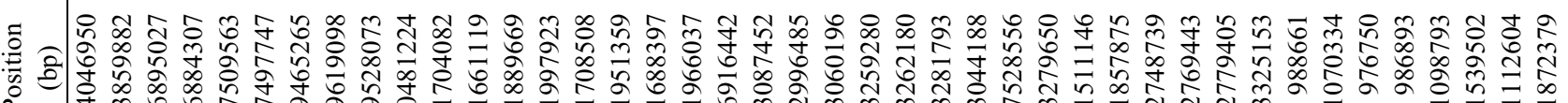

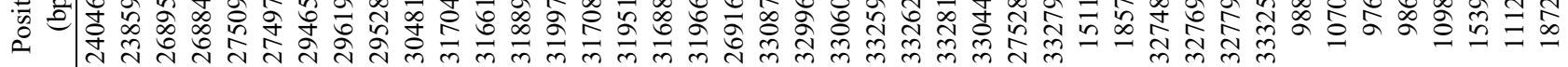

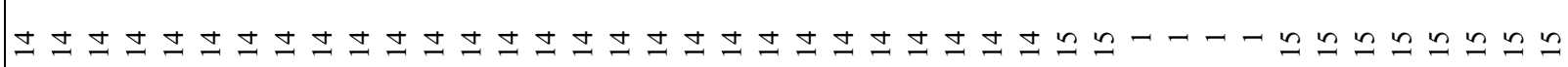
है:

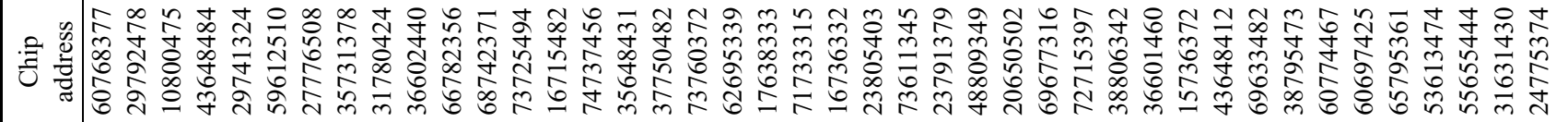

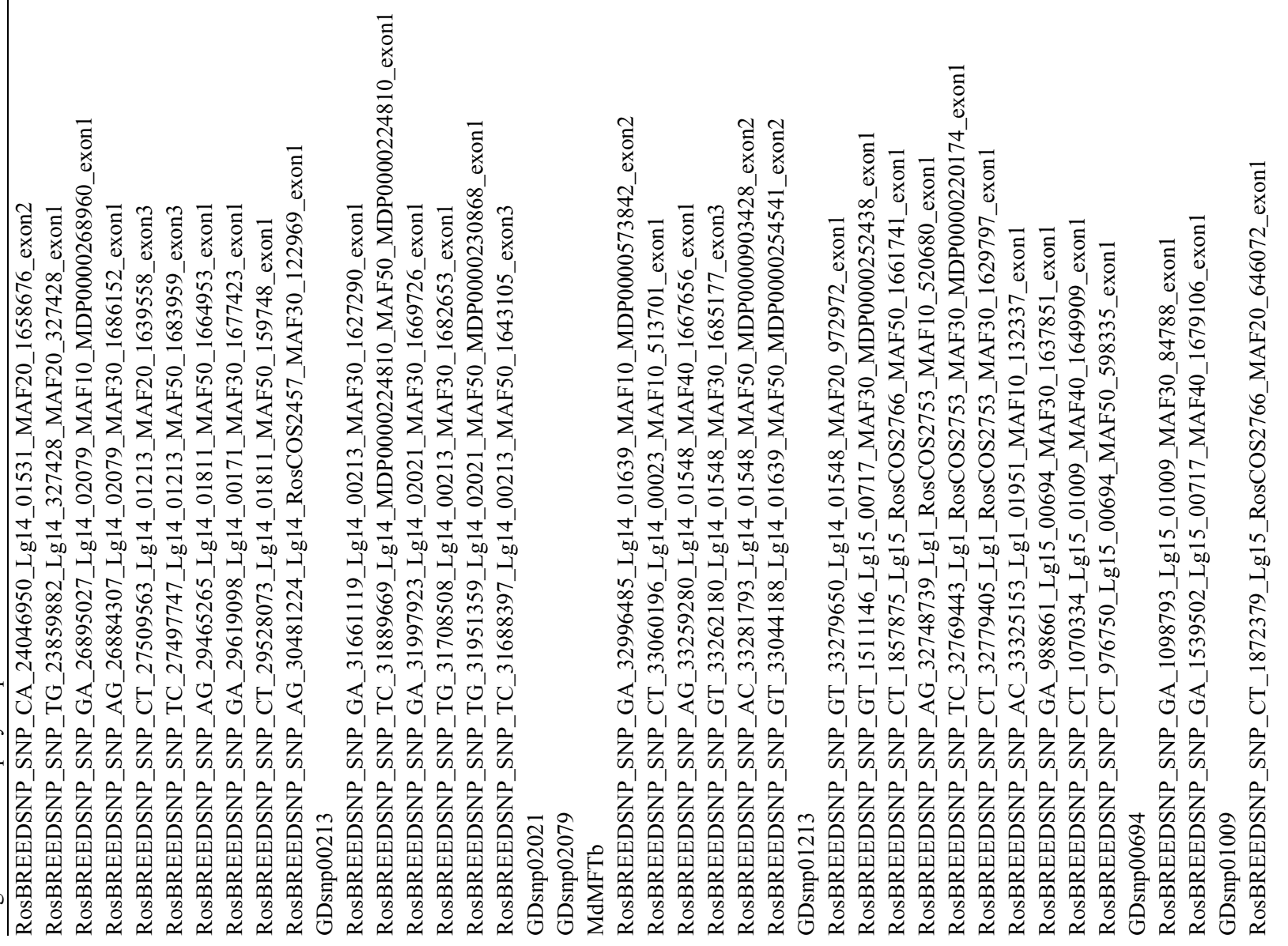




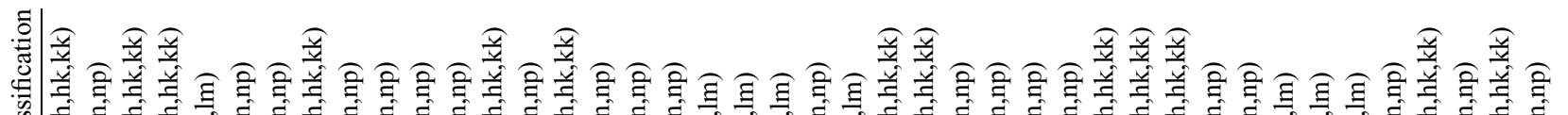

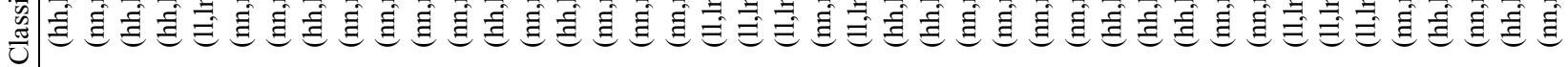

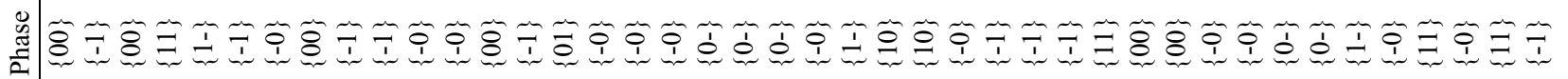

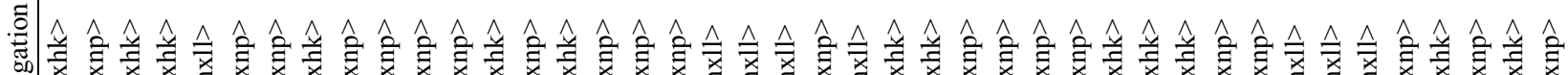

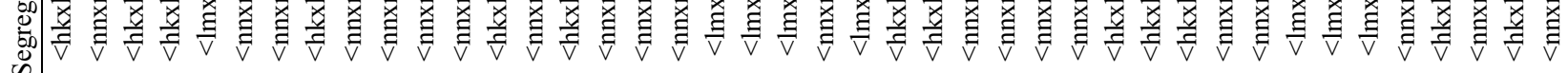

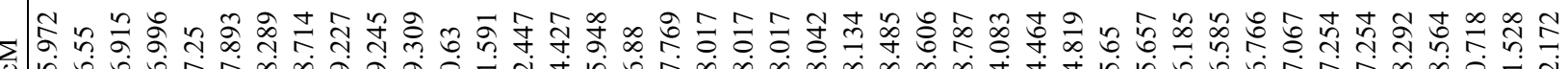

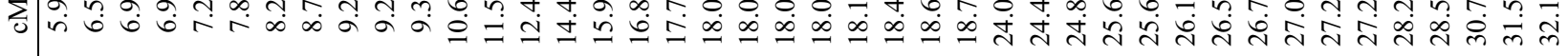

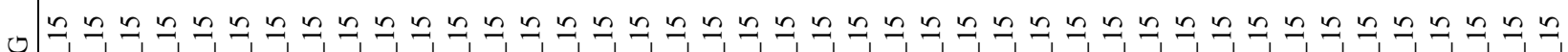

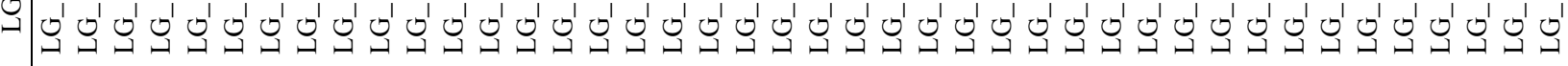

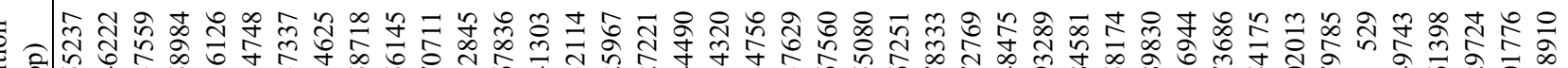

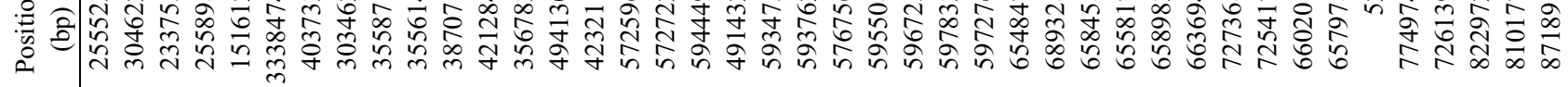

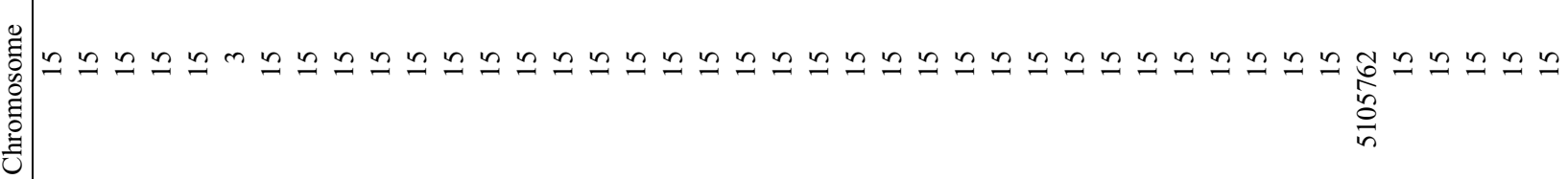

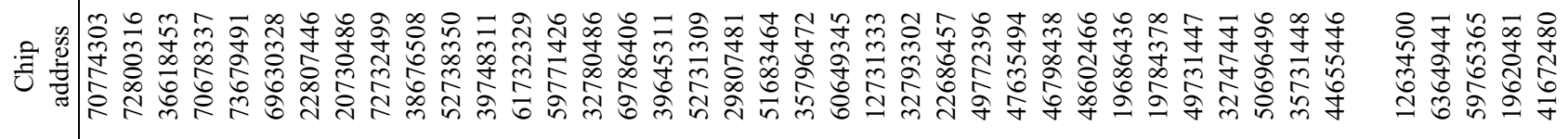

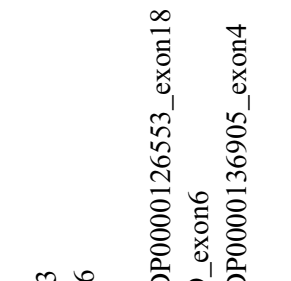

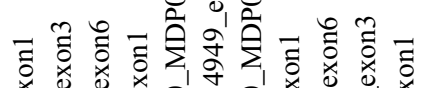

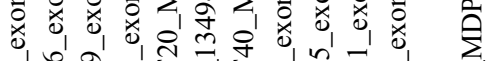

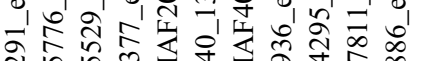

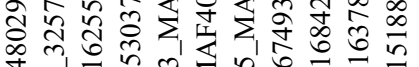

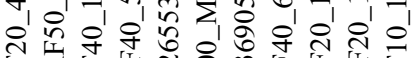

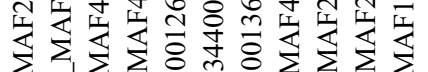

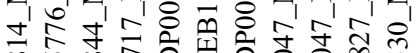

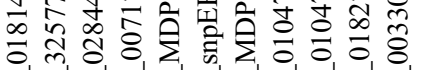
$n^{\prime} n^{\prime} n^{\prime} n^{\prime} n^{\prime} n^{\prime} n^{\prime}$

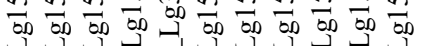

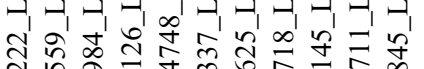

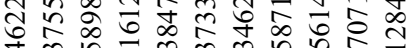

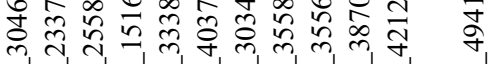

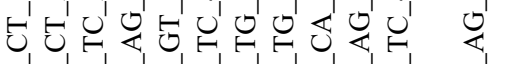

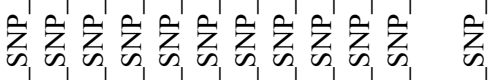

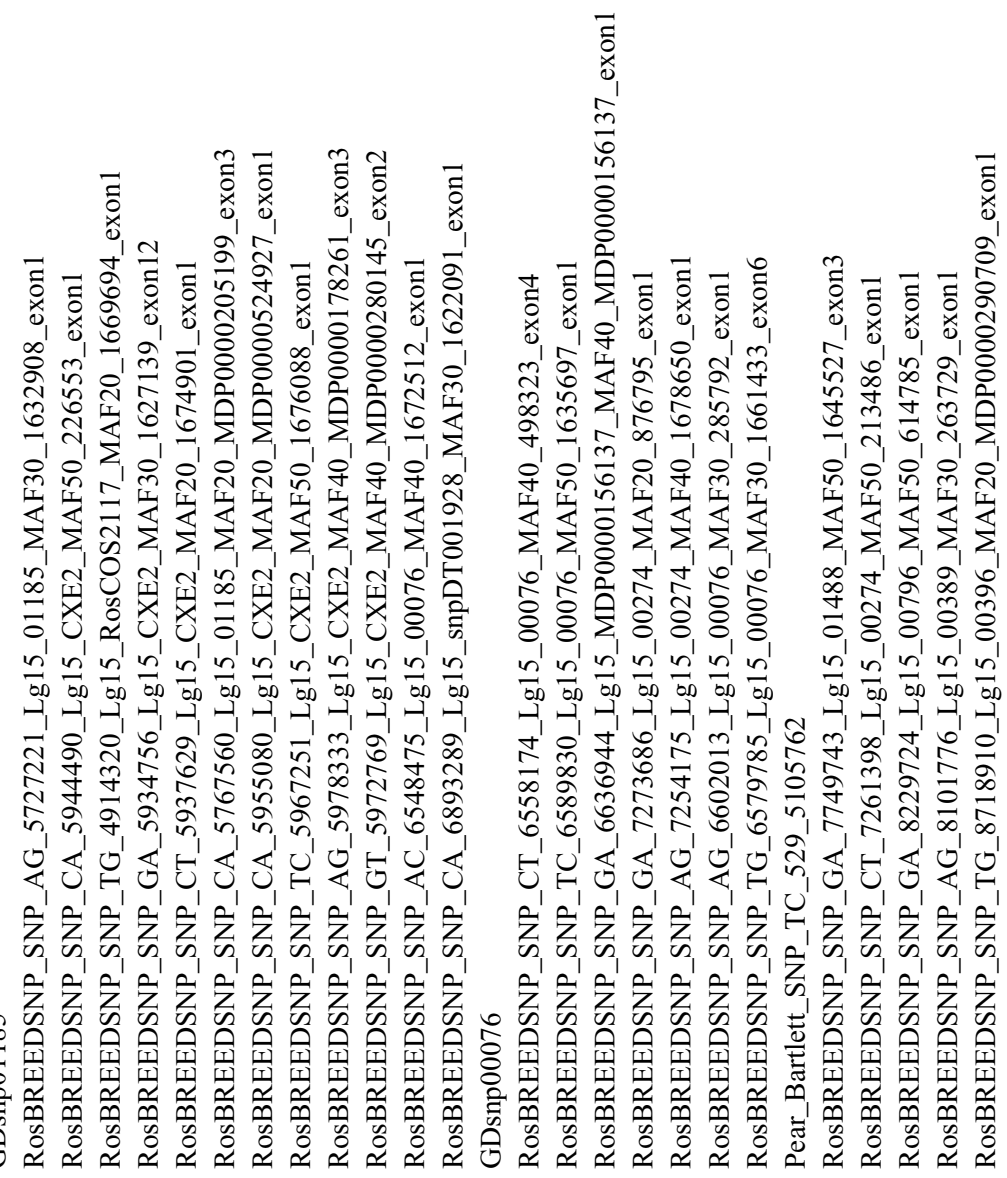




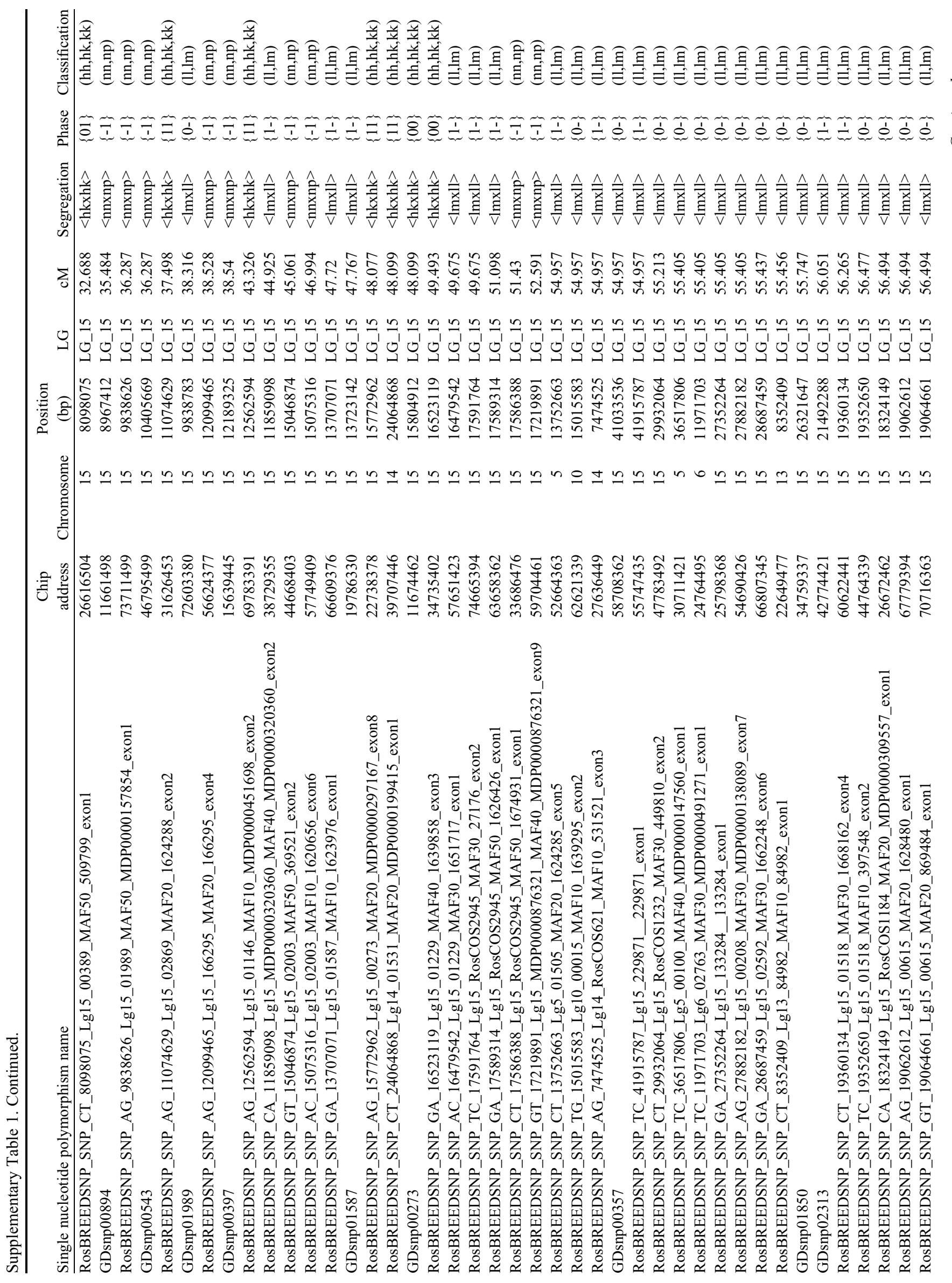




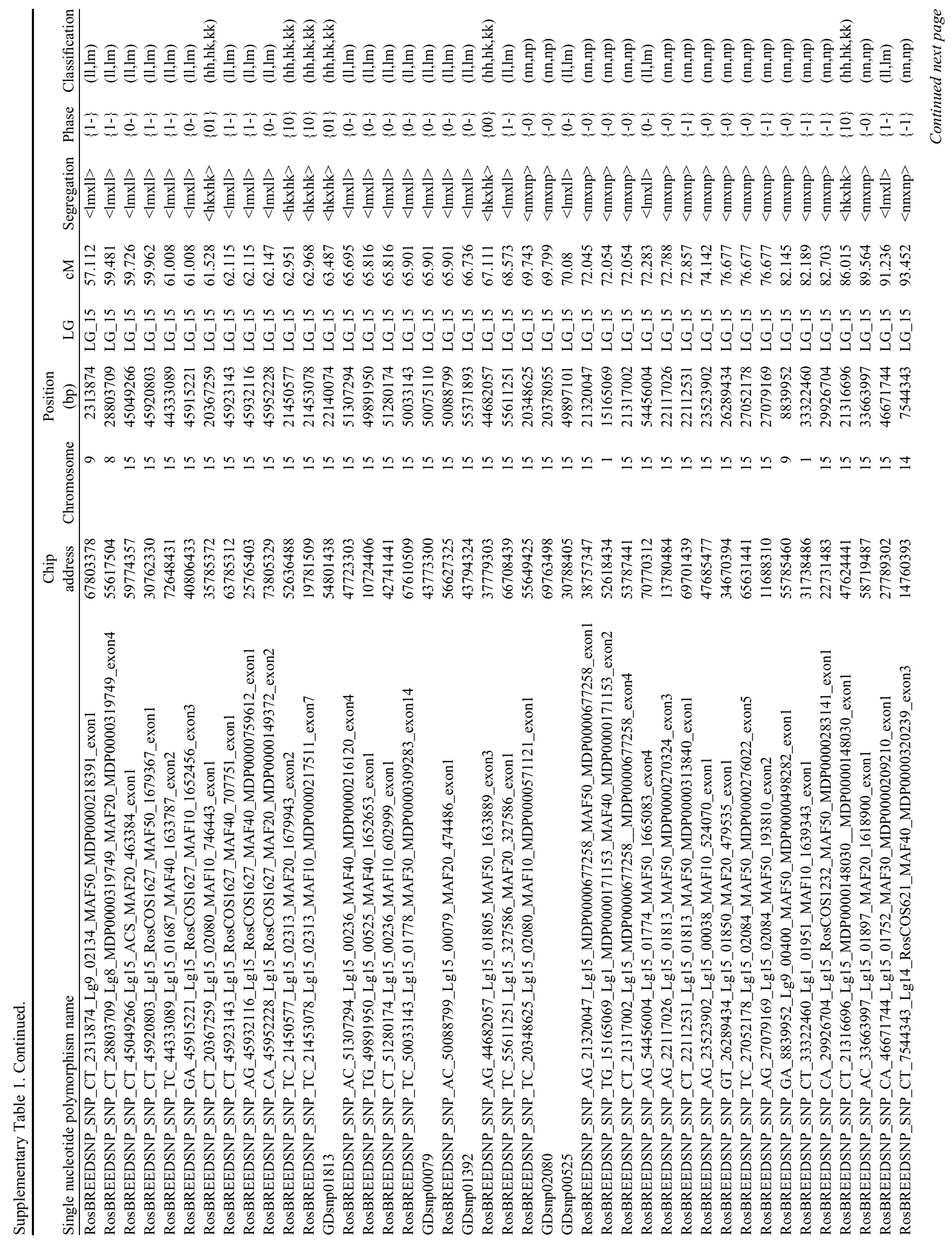




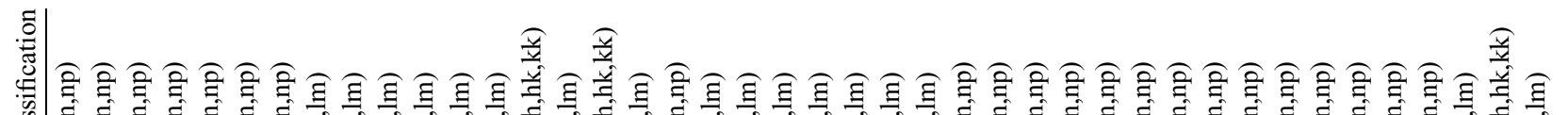

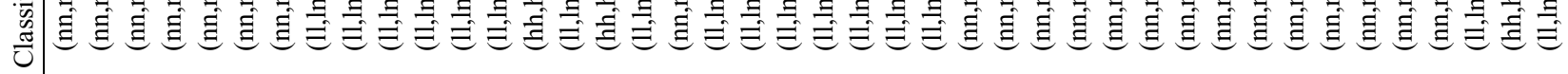

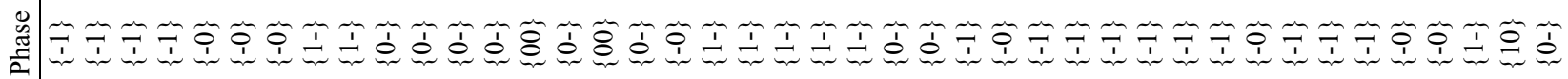

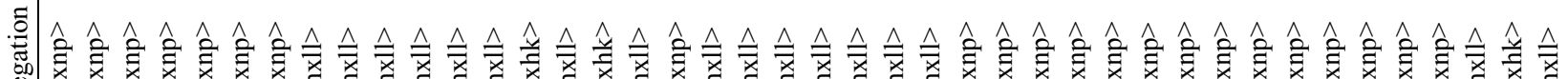

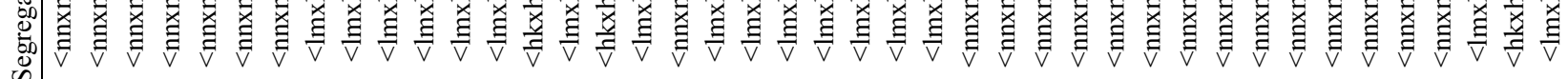
क्ष

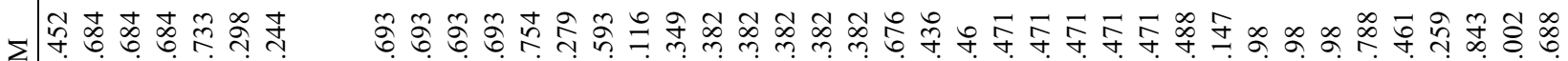

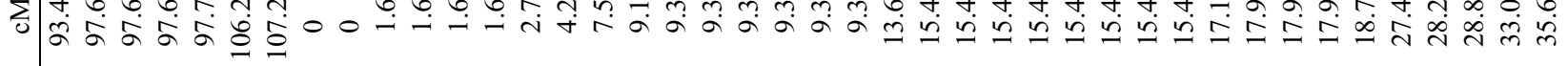

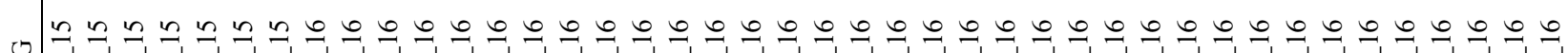

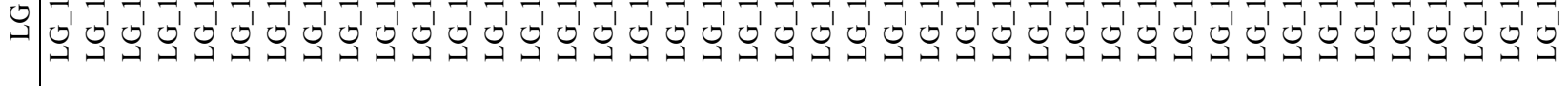
它

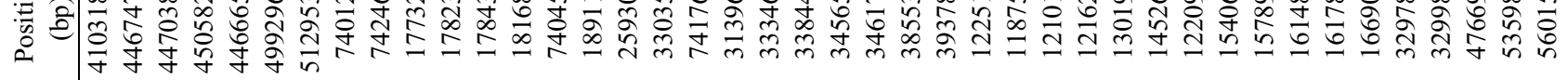

छัฒ

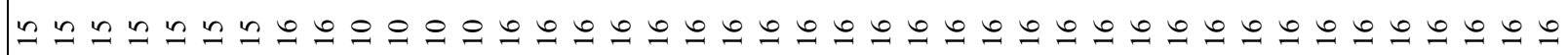

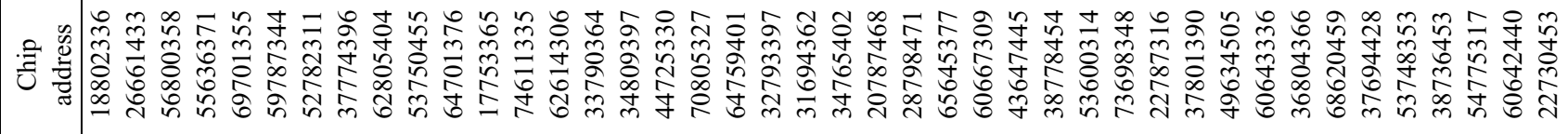

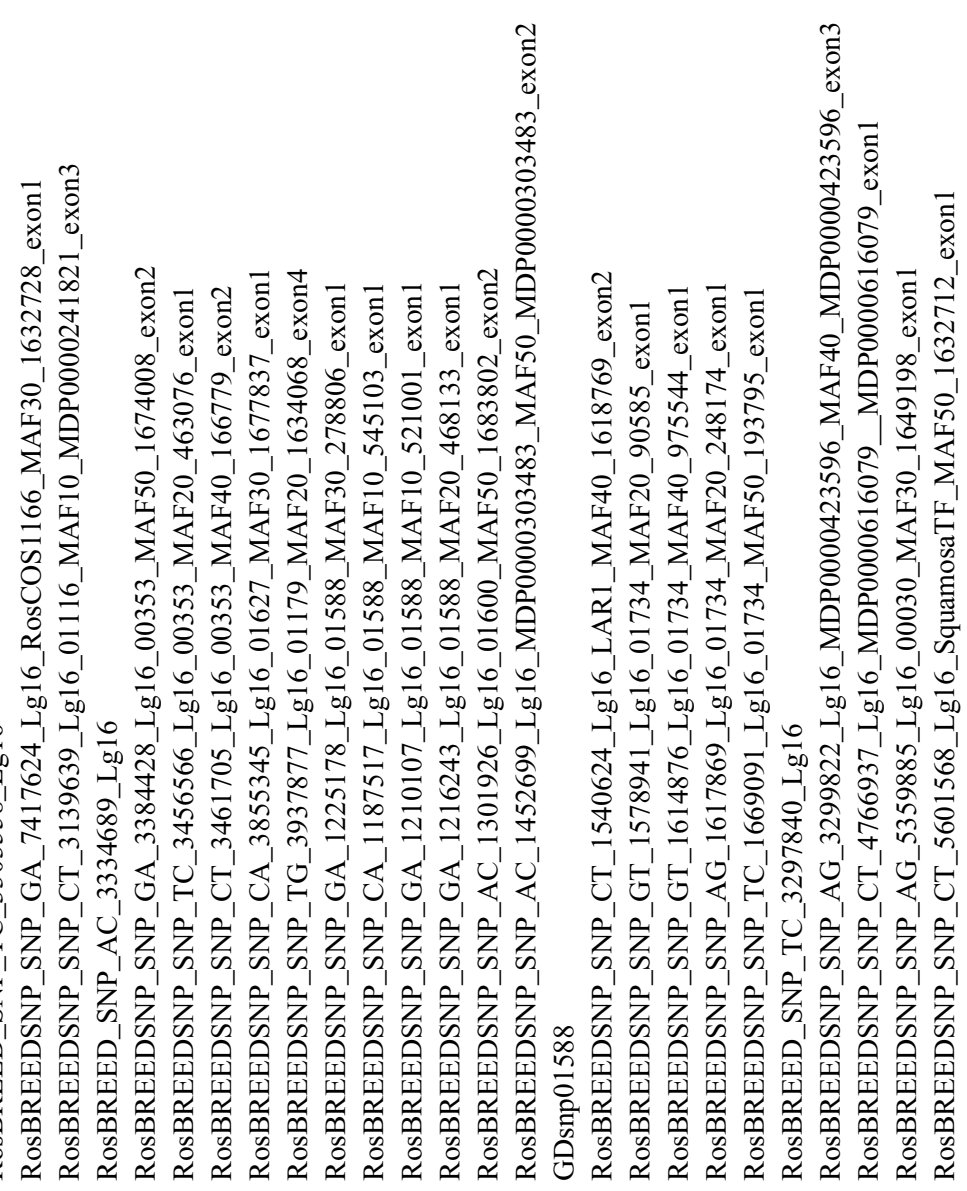




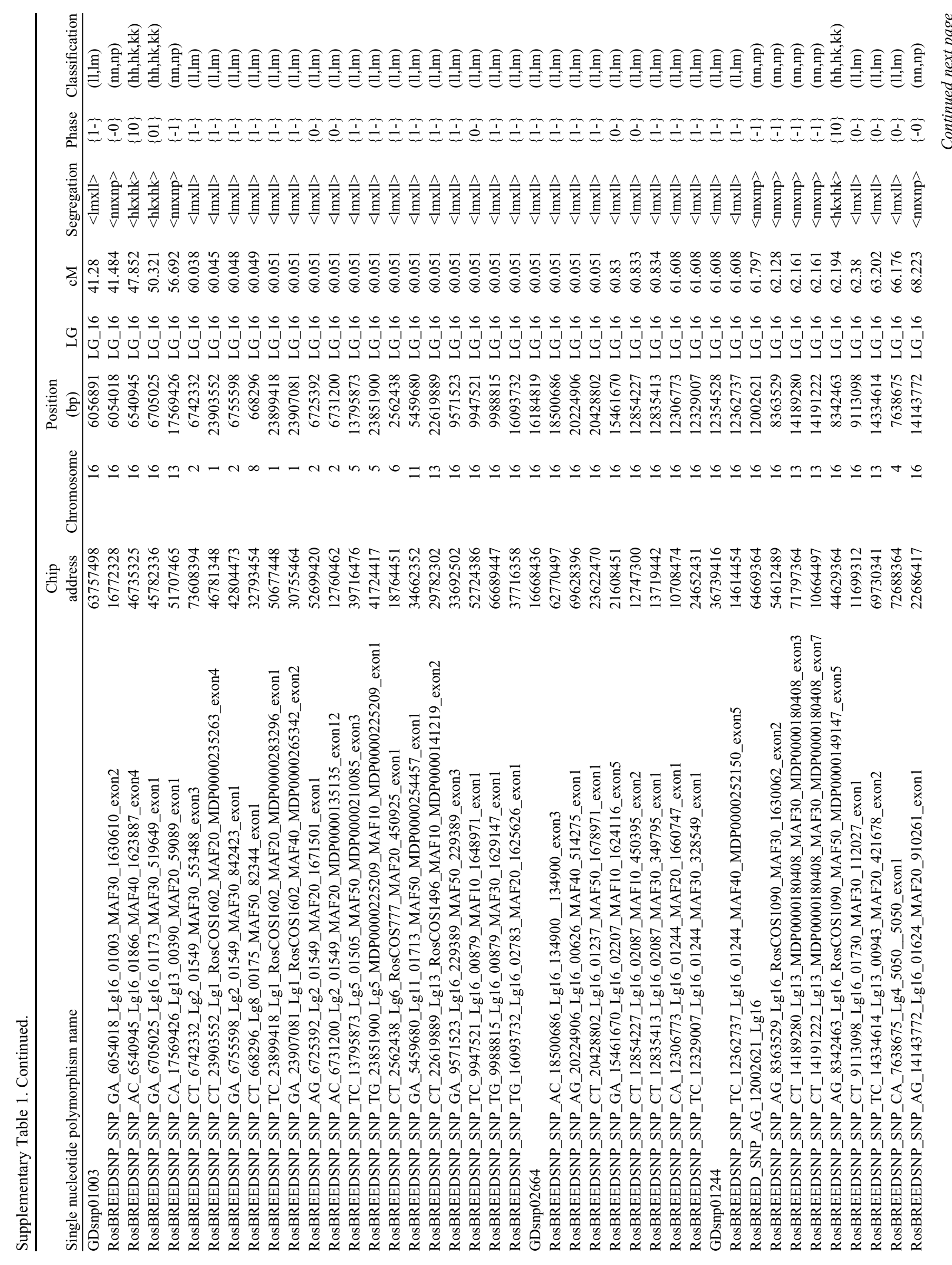


.气⿱艹⿹勹巳

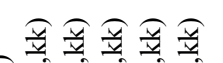

妾

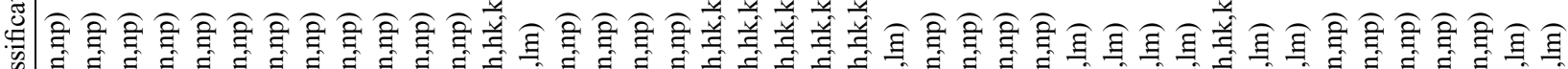

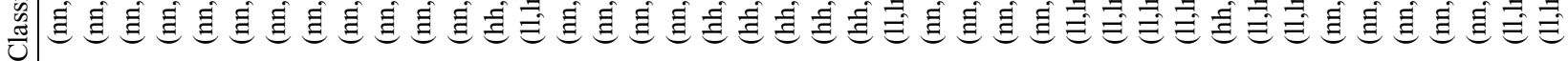

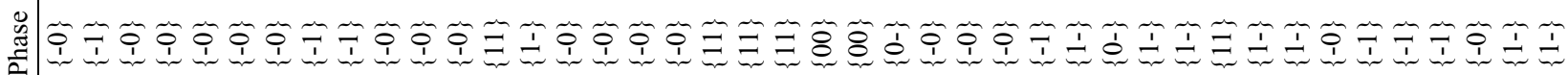

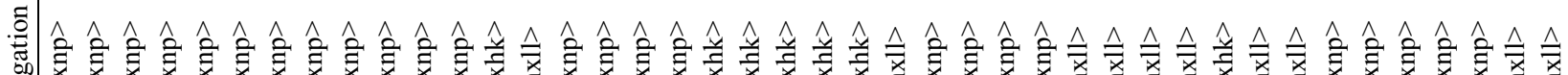

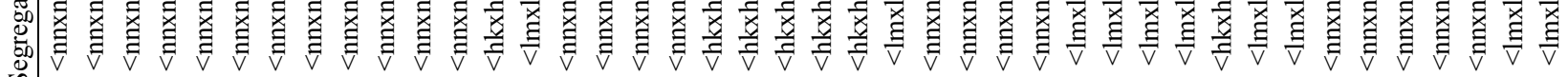
๓

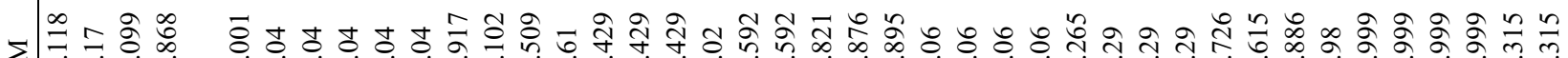
र

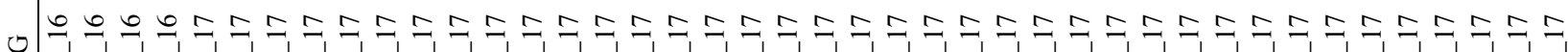
أق

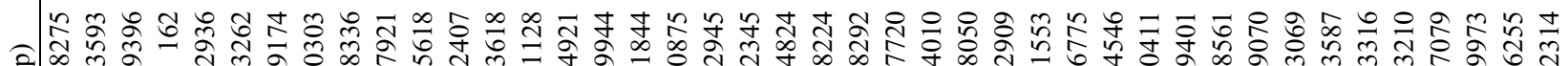

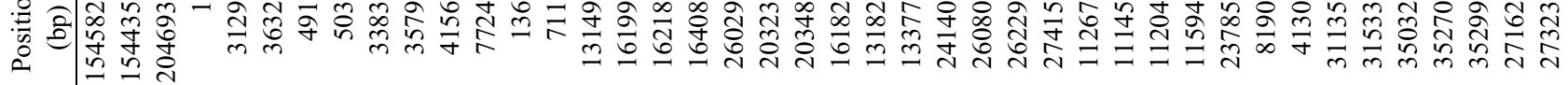

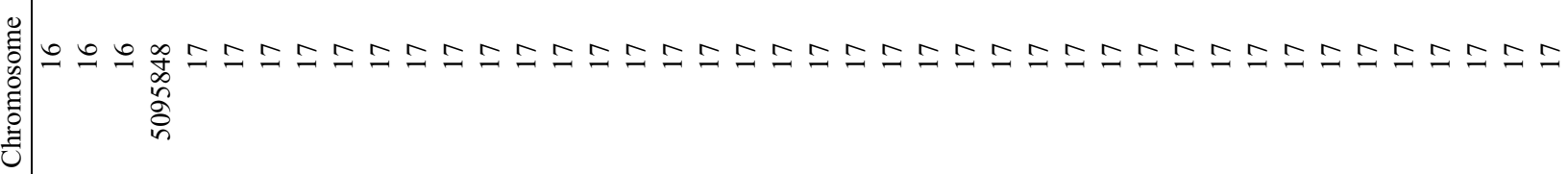

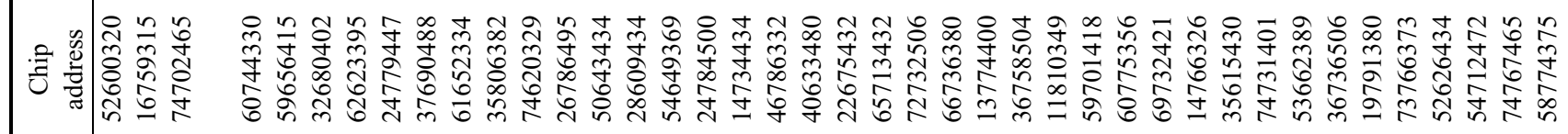

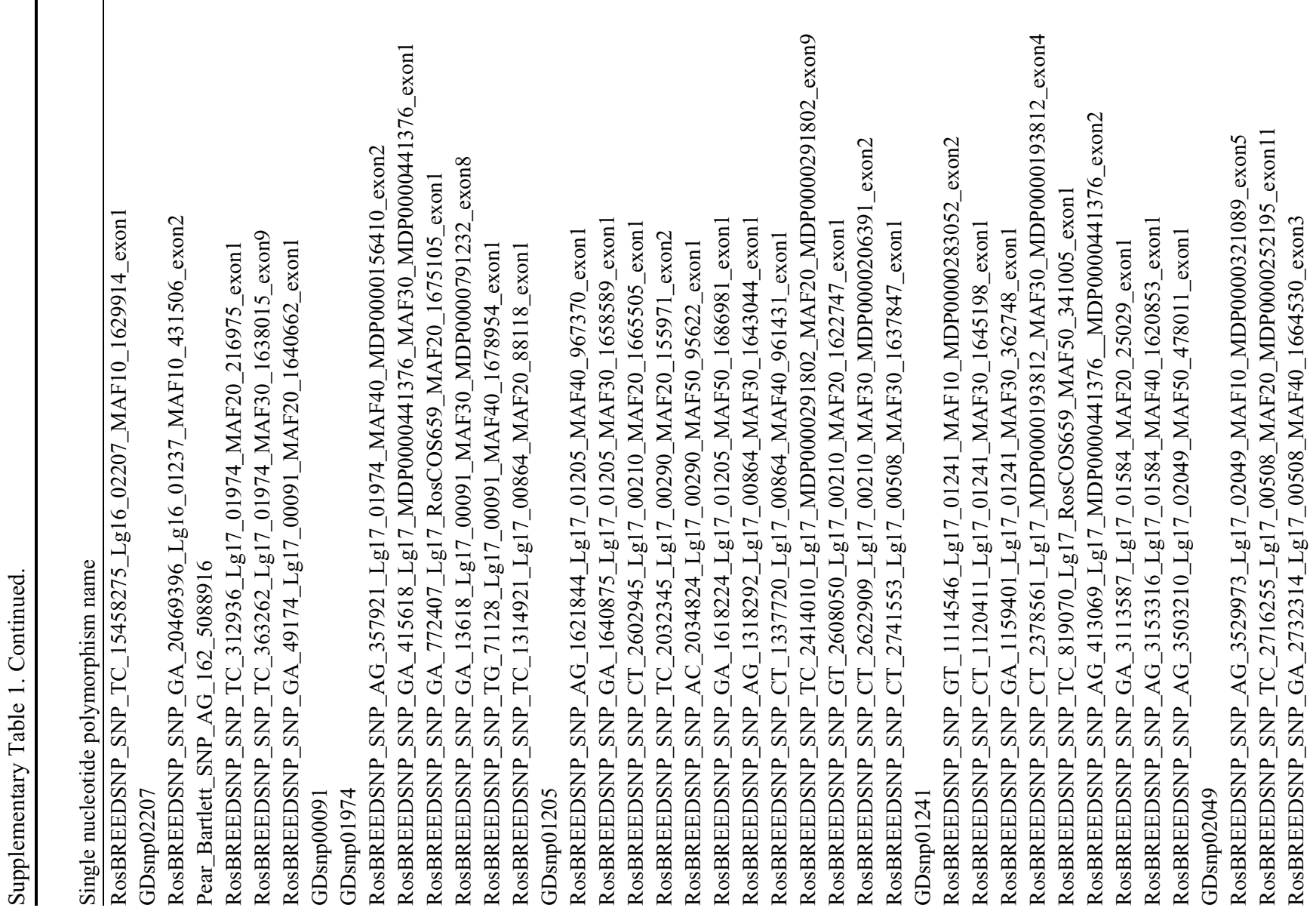




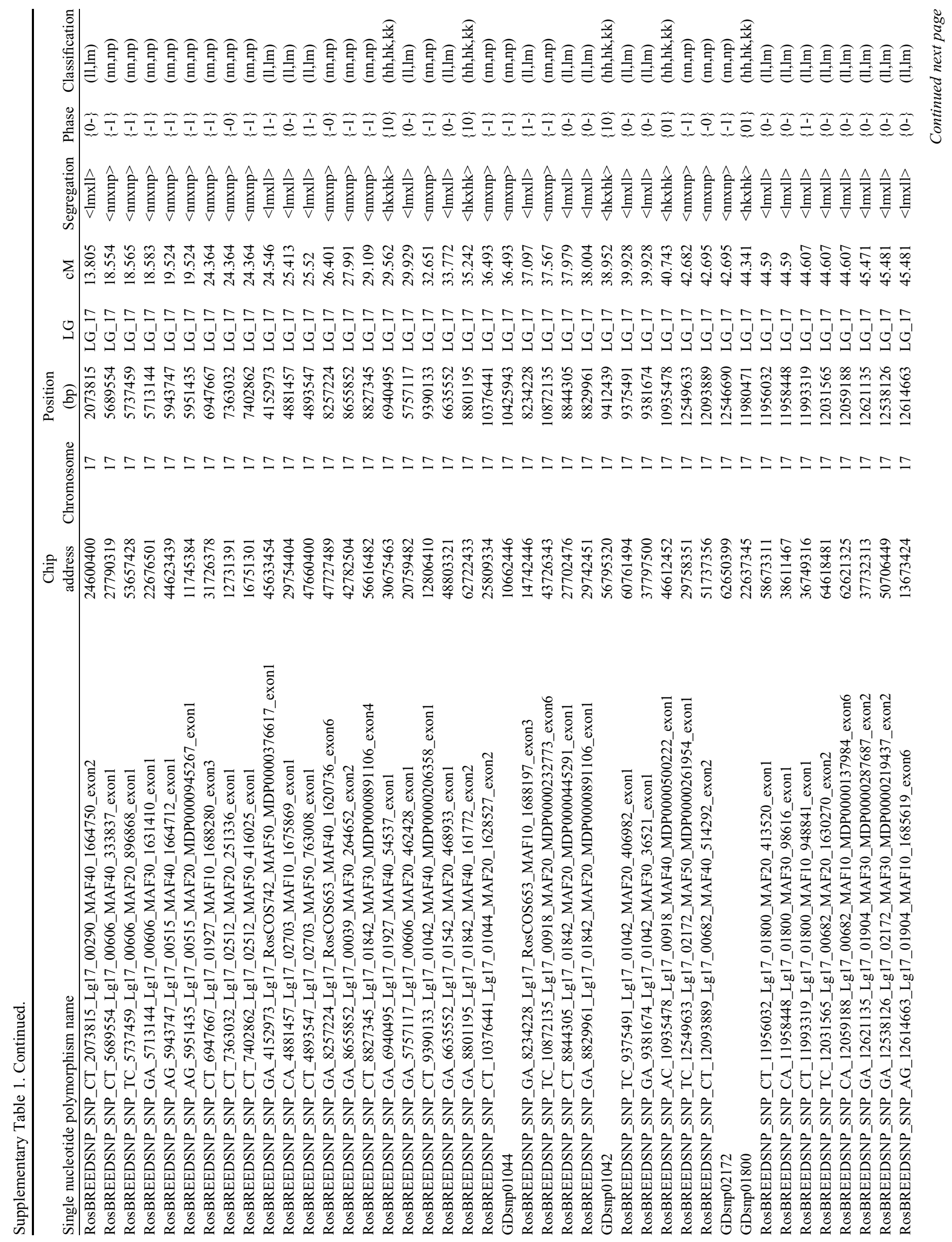




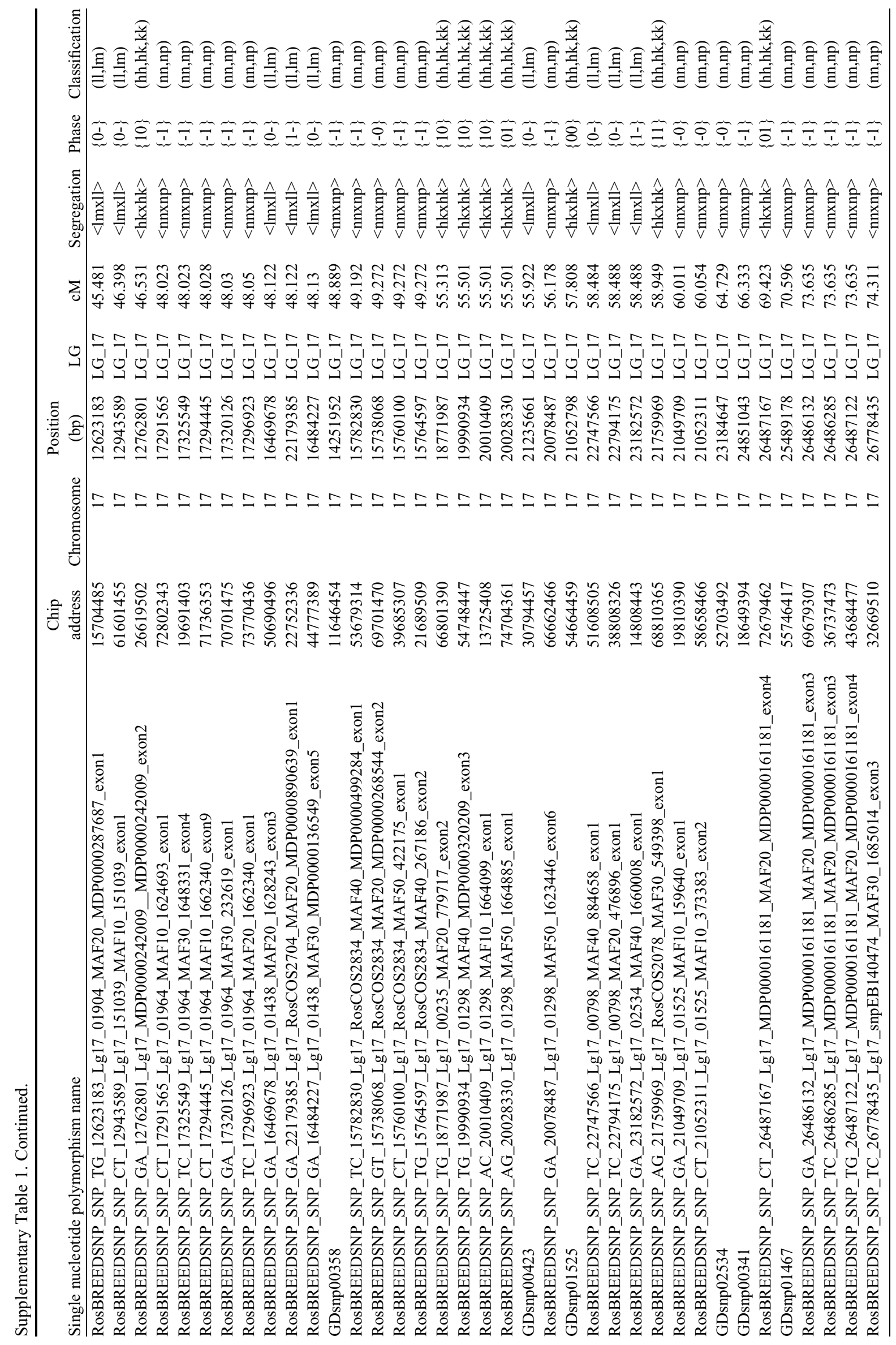




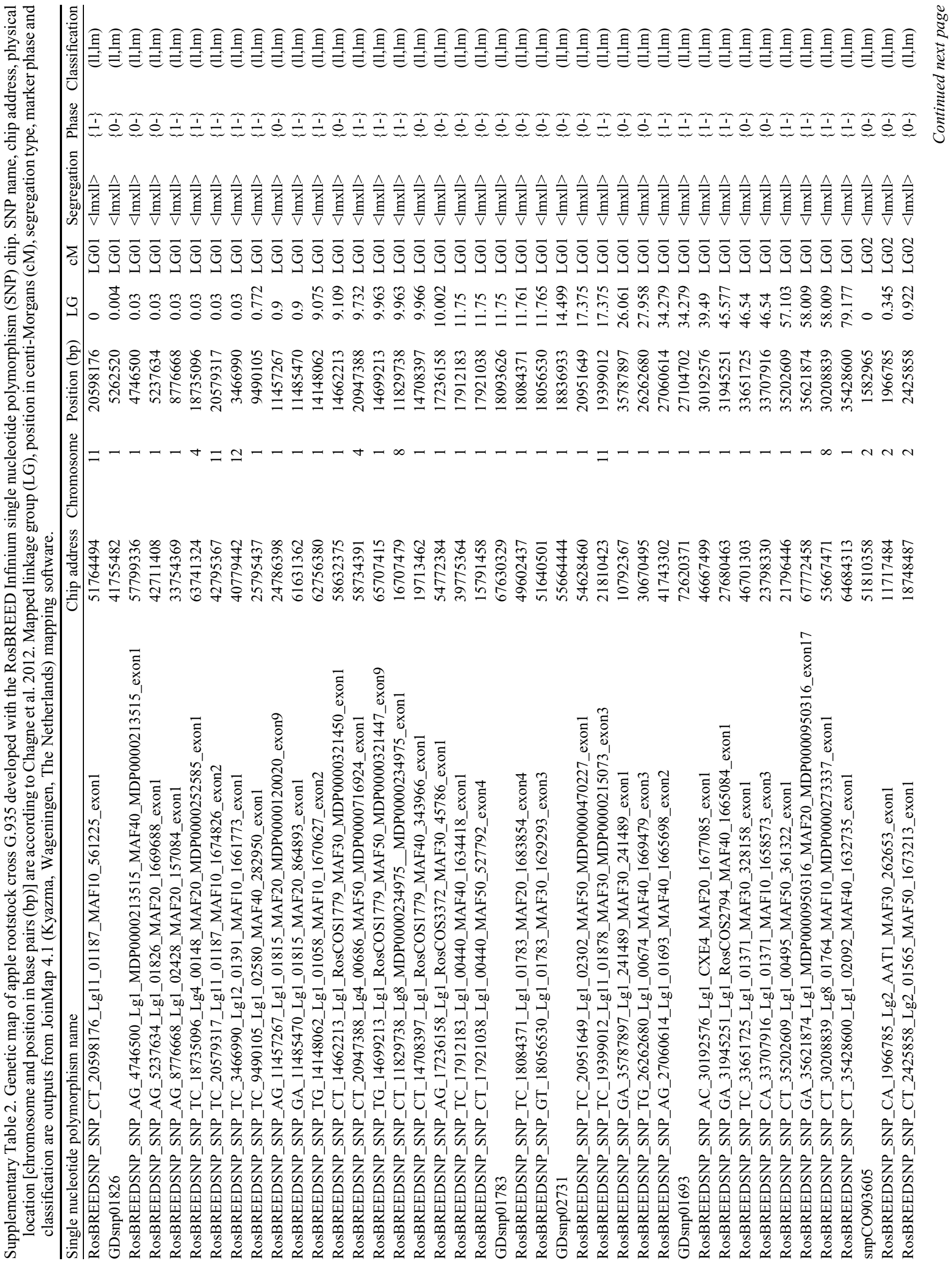




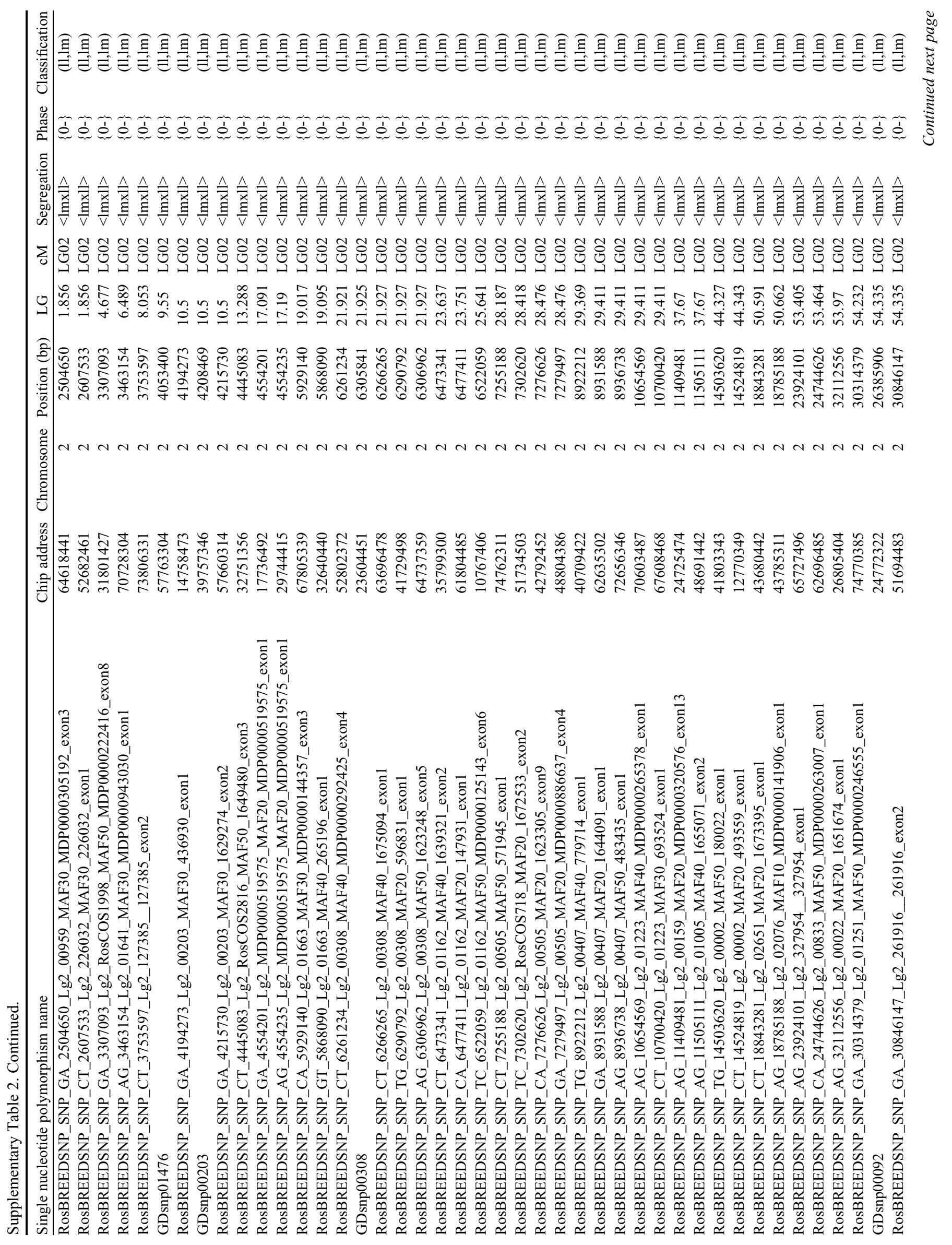




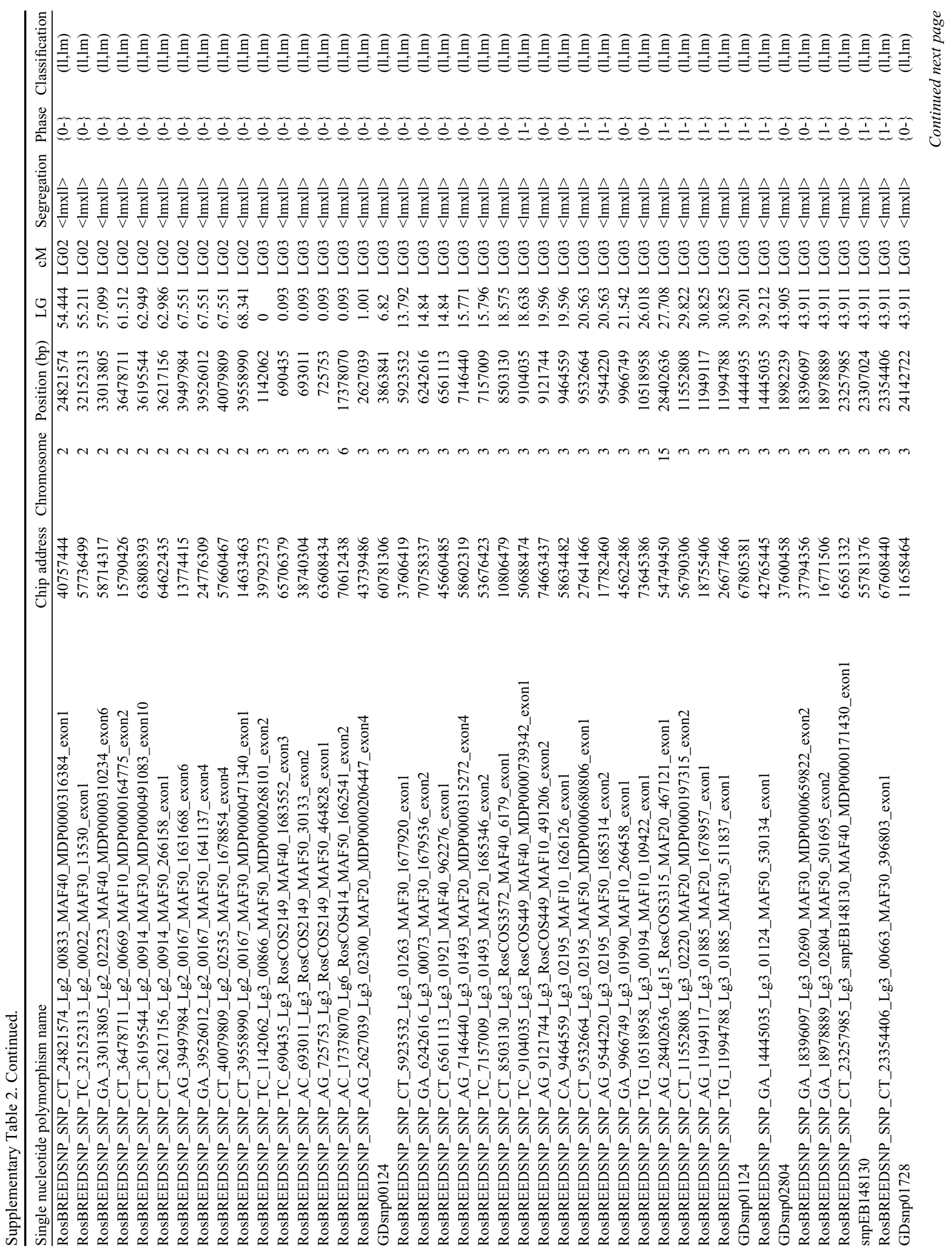




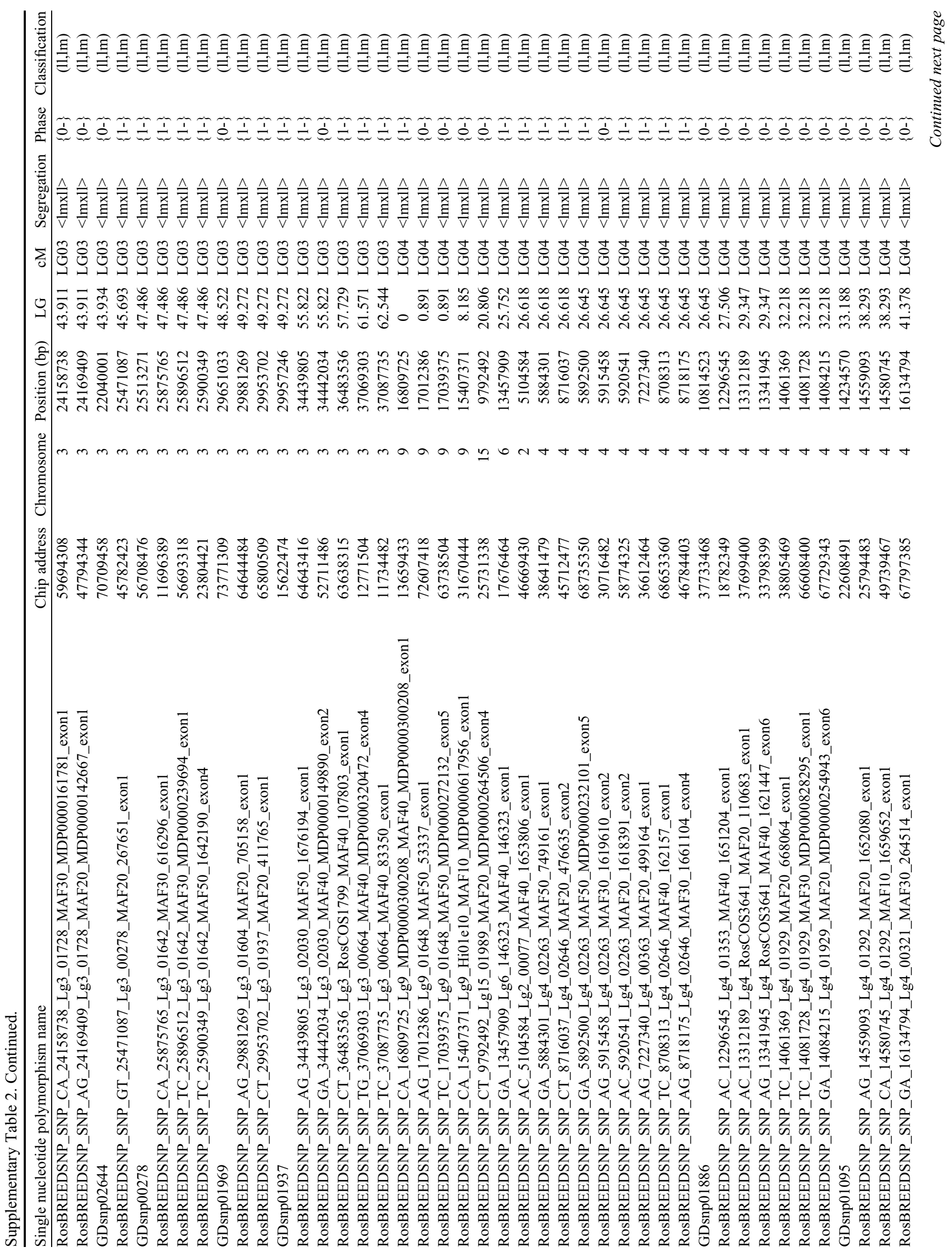




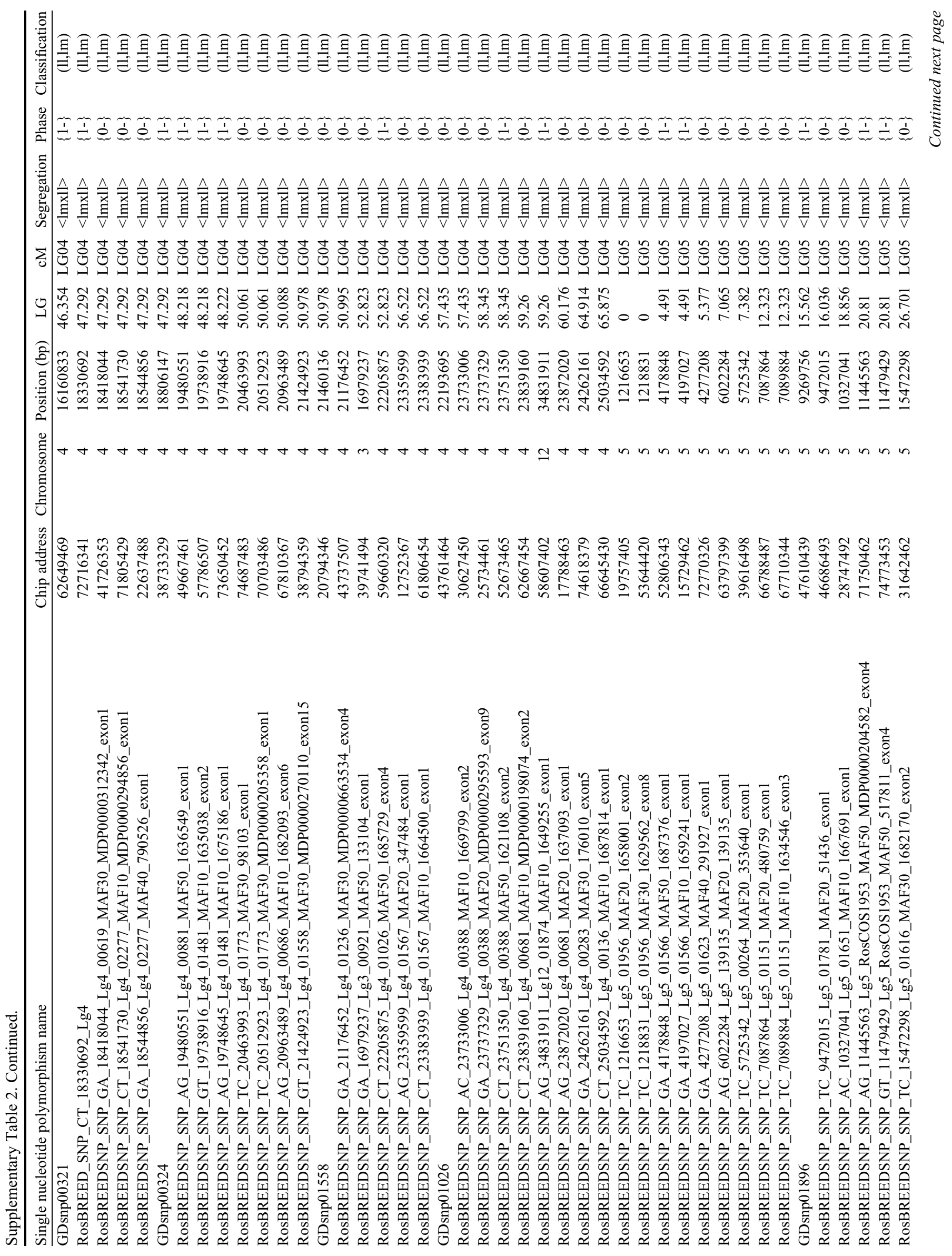




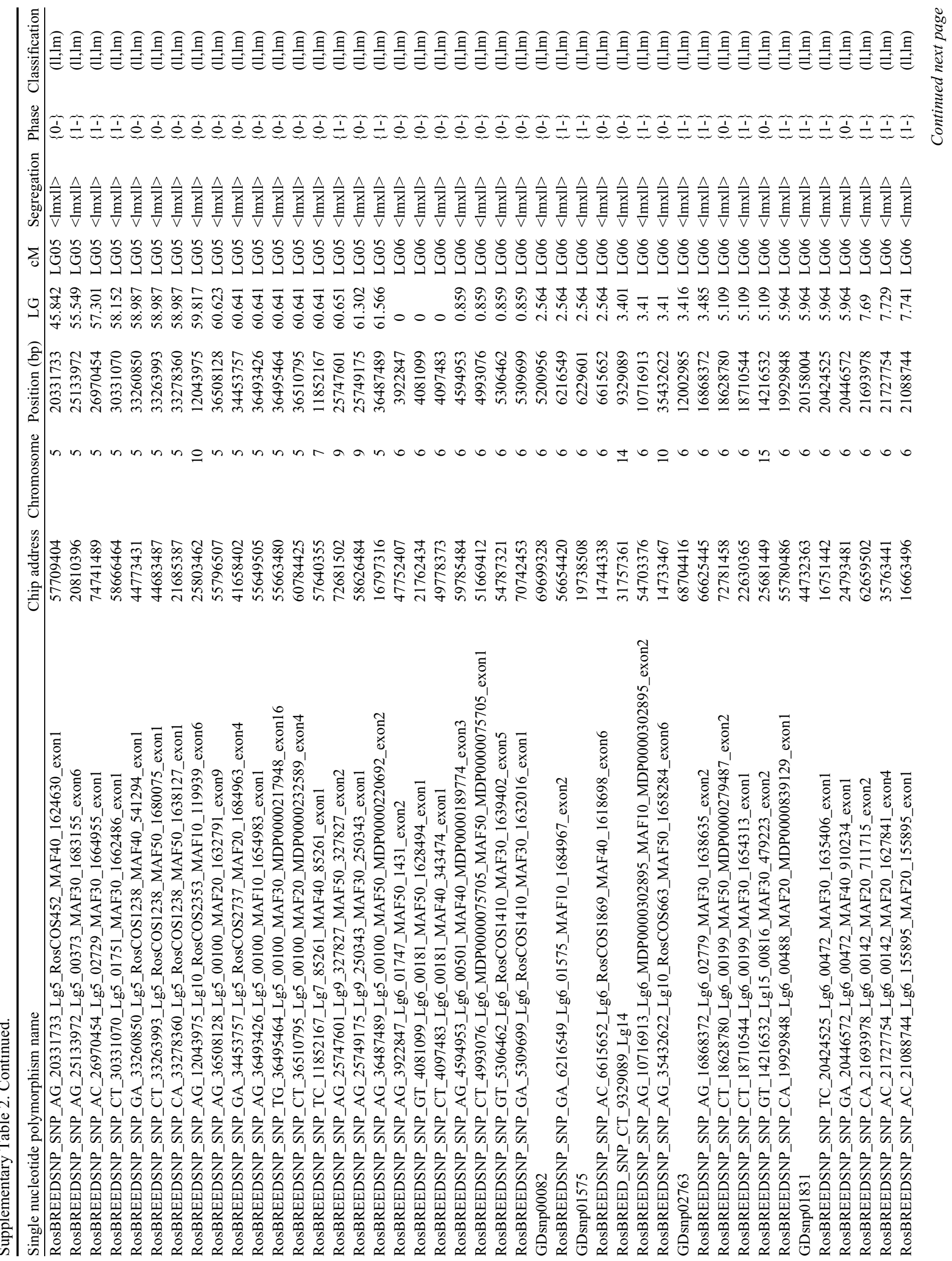




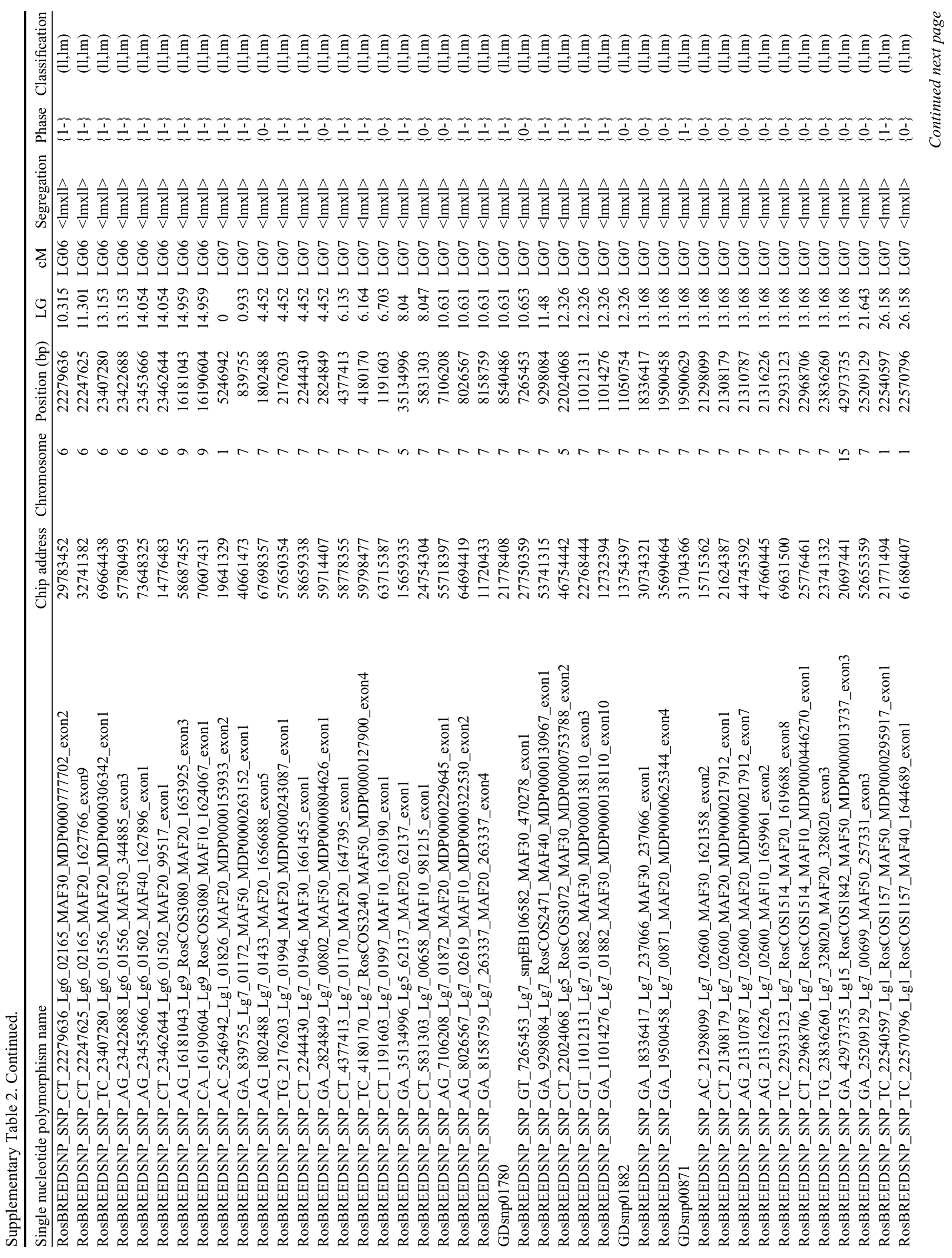




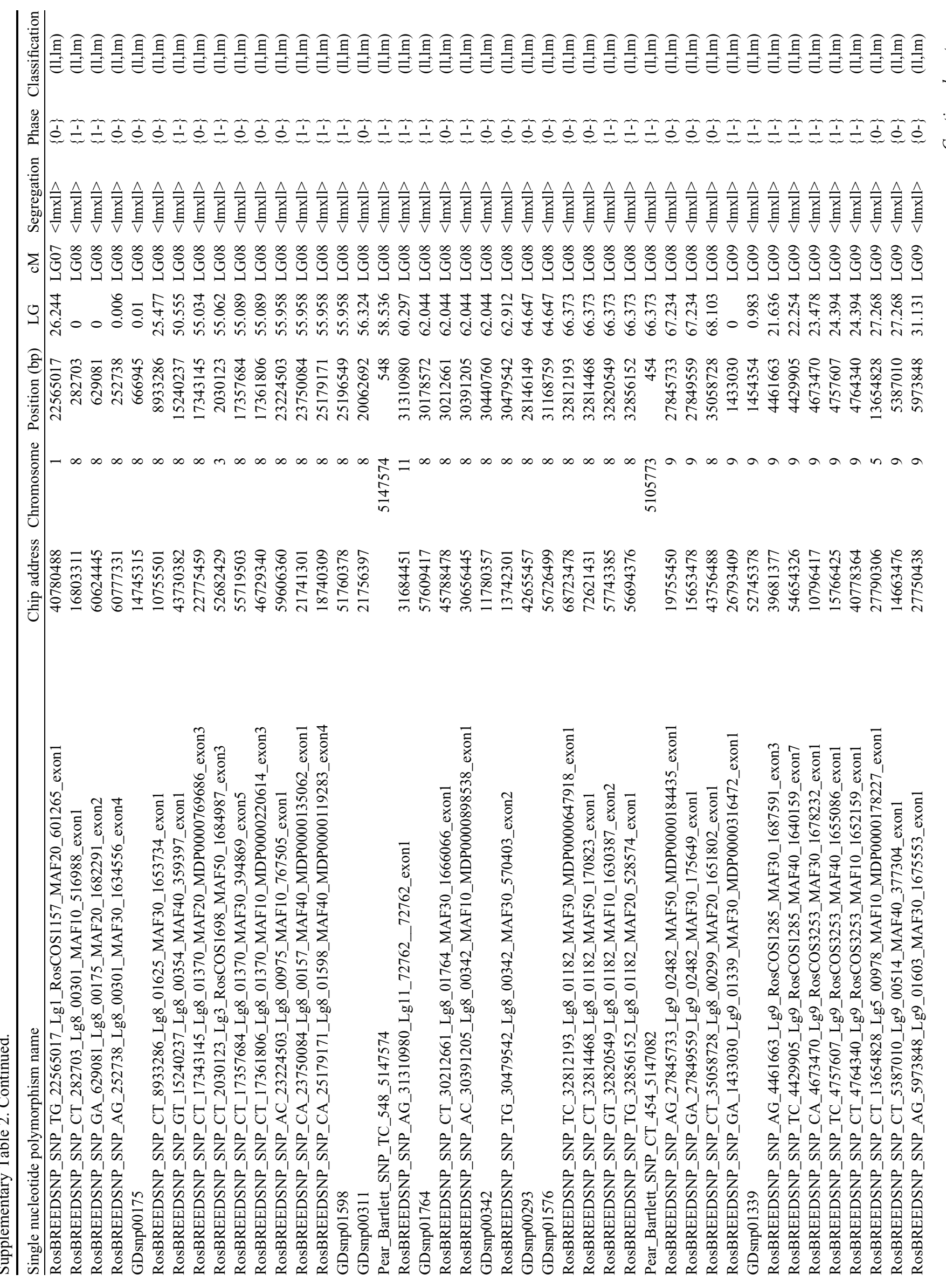




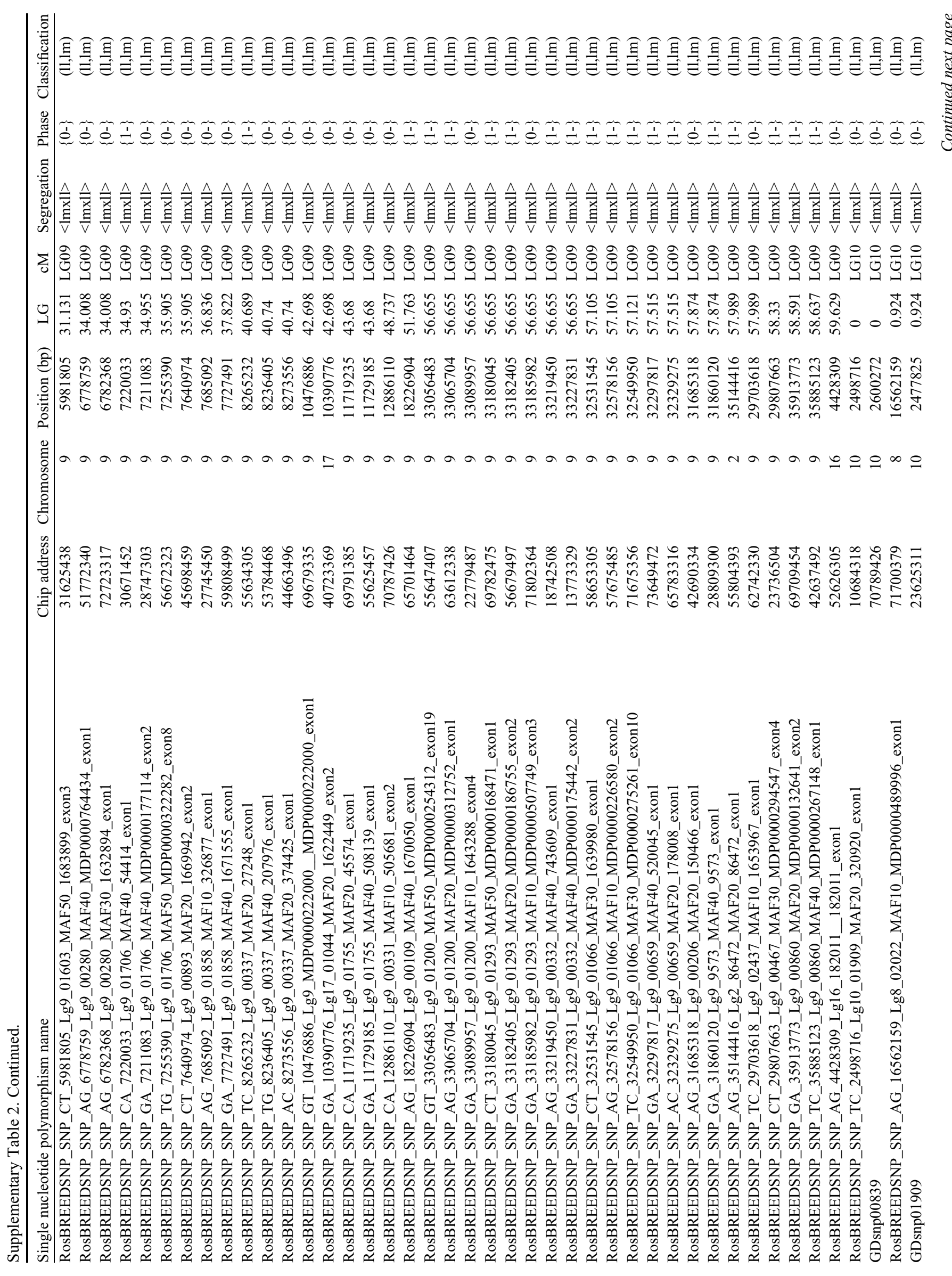




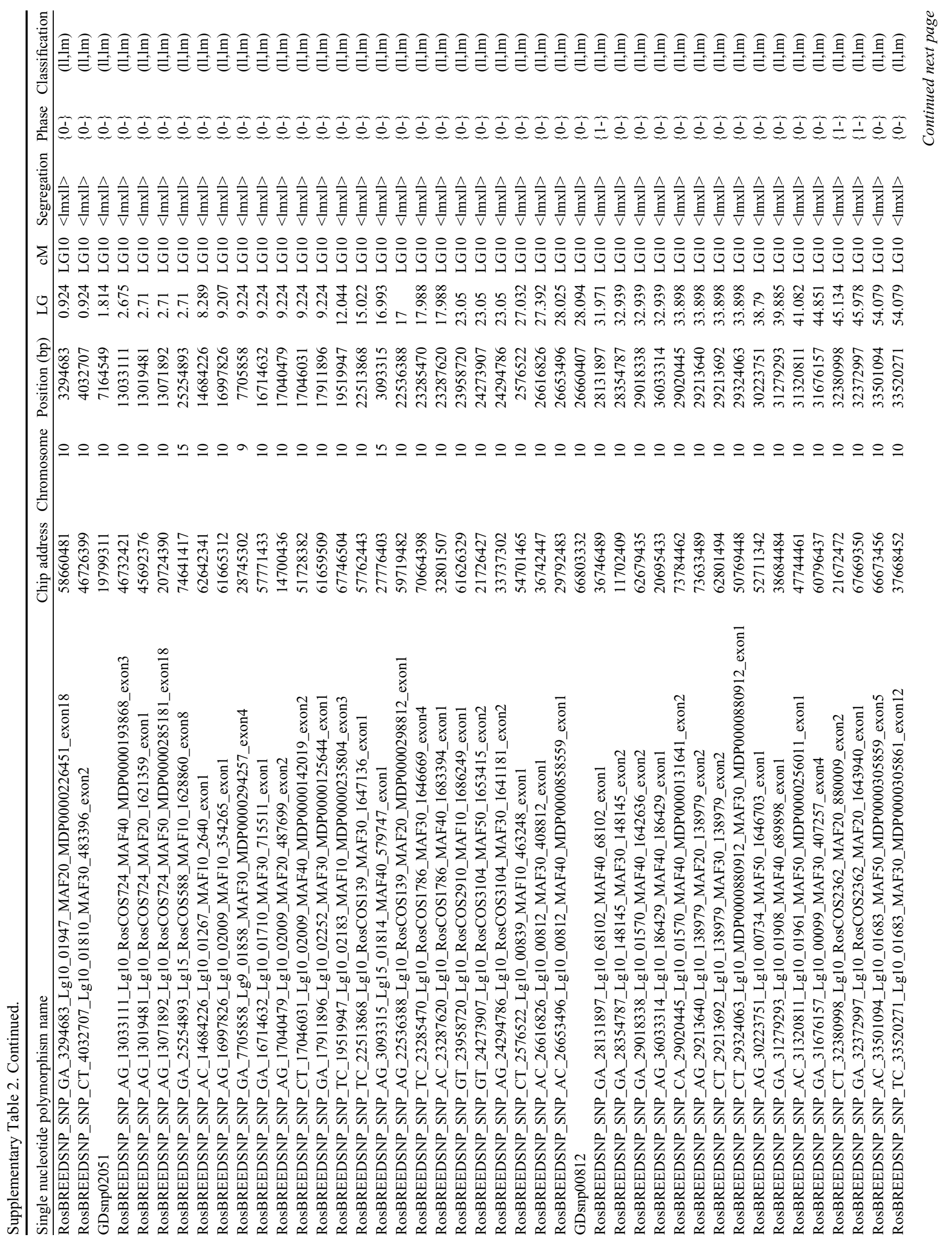




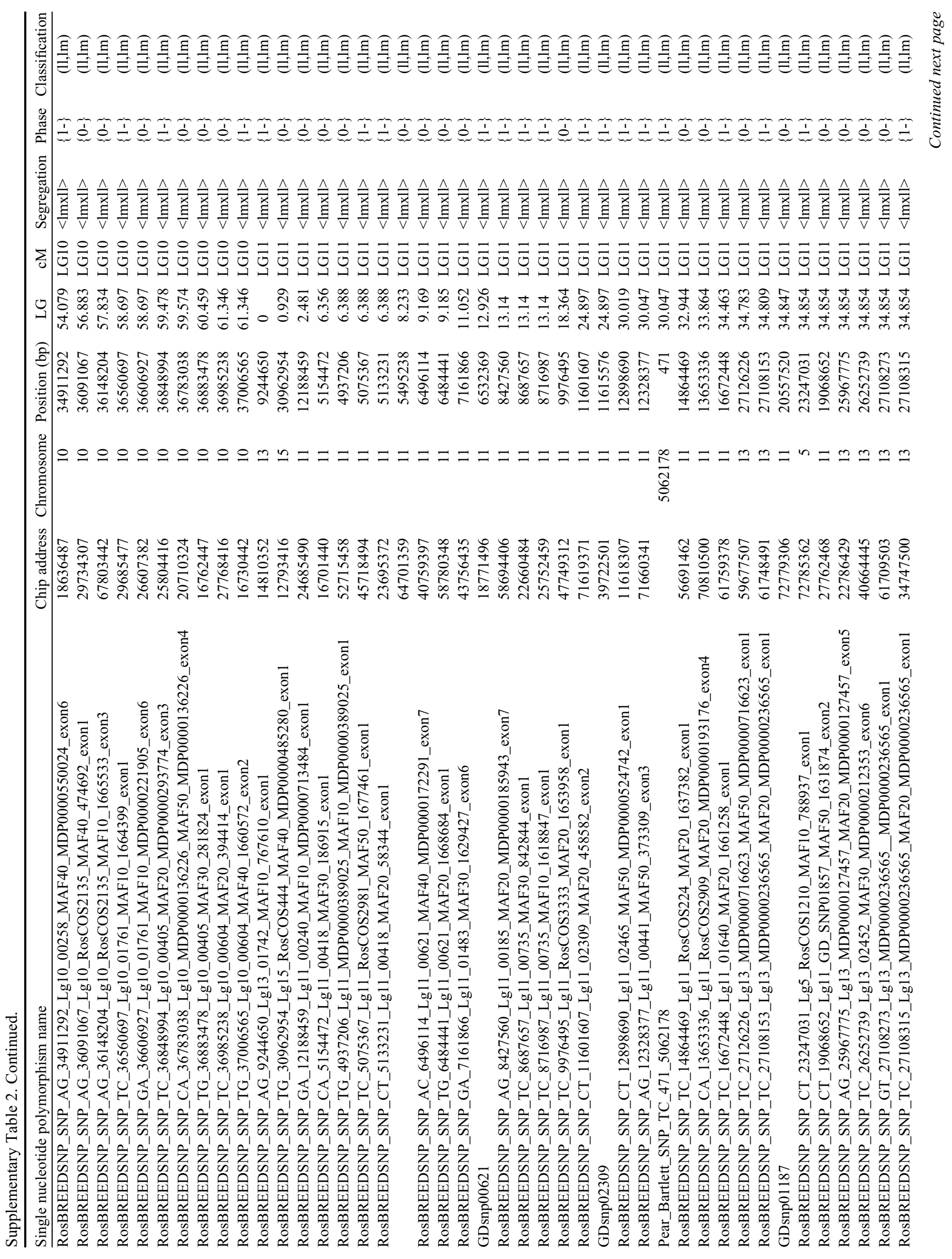




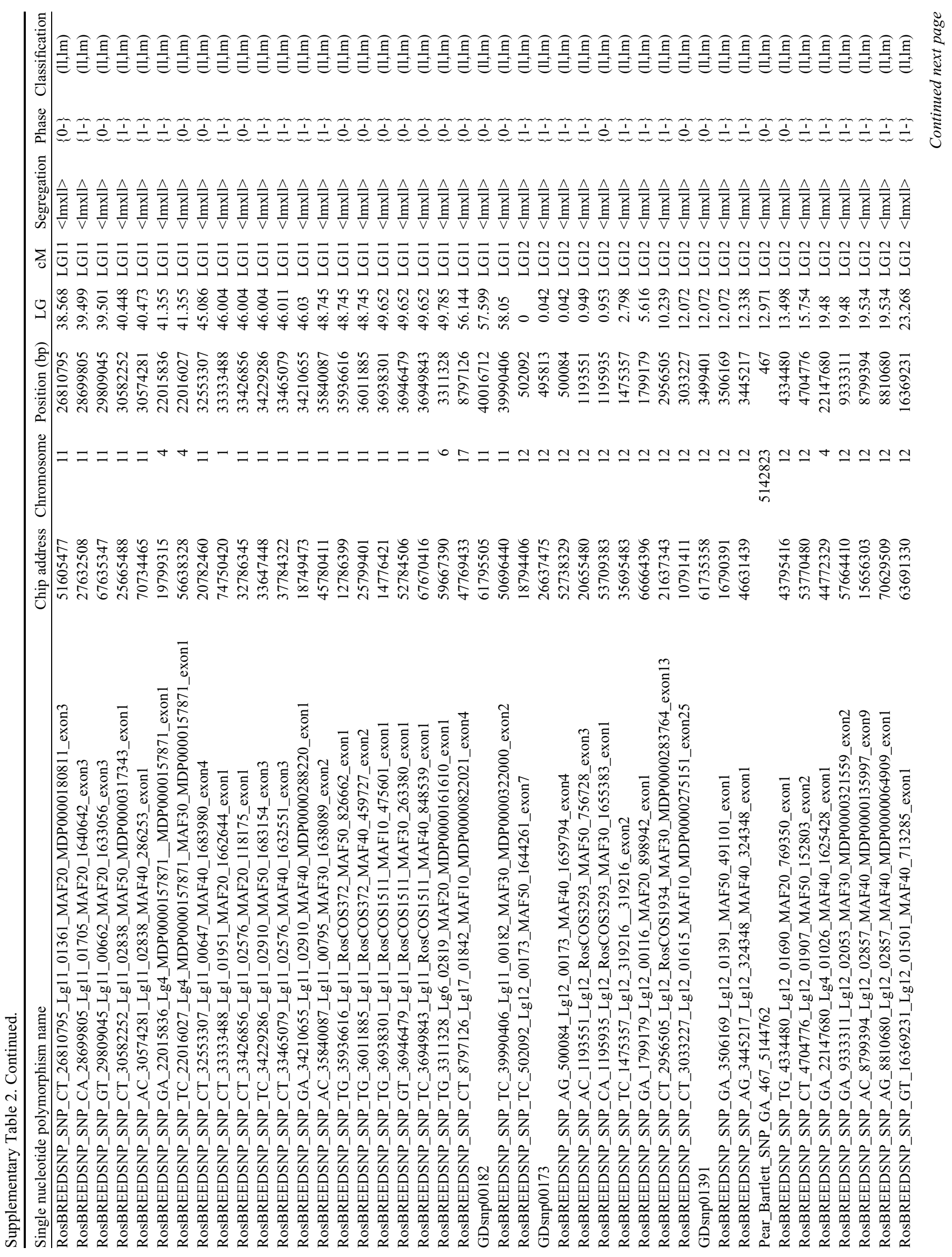




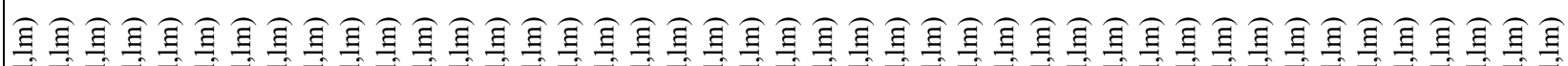

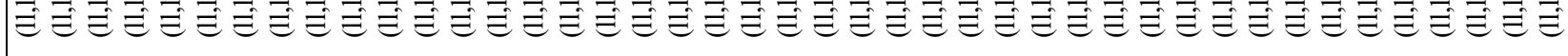

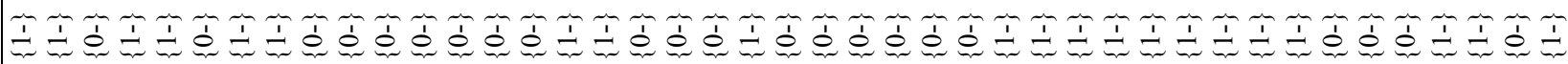

$\hat{\bar{x}} \hat{\bar{x}} \hat{\bar{x}} \hat{\bar{x}} \hat{\bar{x}} \hat{\bar{x}} \hat{\bar{x}} \hat{\bar{x}} \hat{\bar{x}} \hat{\bar{x}} \hat{\bar{x}} \hat{\bar{x}} \hat{\bar{x}} \hat{\bar{x}} \hat{\bar{x}} \hat{\bar{x}} \hat{\bar{x}} \hat{\bar{x}} \hat{\bar{x}} \hat{\bar{x}} \hat{\bar{x}} \hat{\bar{x}} \hat{\bar{x}} \hat{\bar{x}} \hat{\bar{x}} \hat{\bar{x}} \hat{\bar{x}} \hat{\bar{x}} \hat{\bar{x}} \hat{\bar{x}} \hat{\bar{x}} \hat{\bar{x}} \hat{\bar{x}} \hat{\bar{x}} \hat{\bar{x}} \hat{\bar{x}} \hat{\bar{x}} \hat{\bar{x}} \hat{\bar{x}} \hat{\bar{x}} \hat{\bar{x}} \hat{\bar{x}} \hat{\bar{x}} \hat{\bar{x}}$

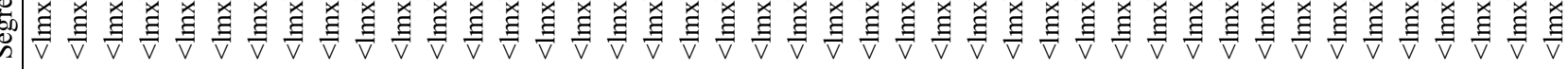

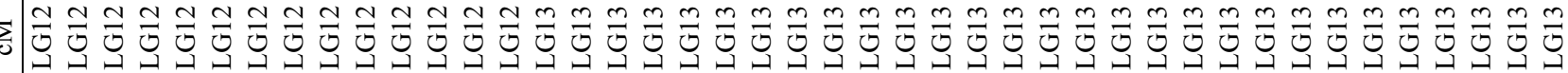
ن

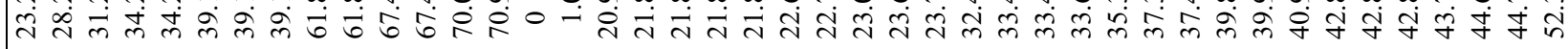

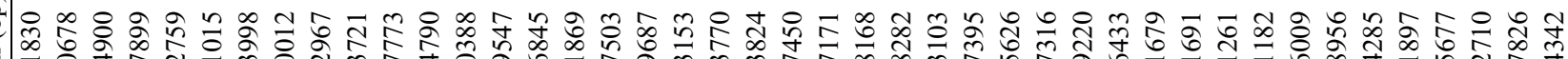

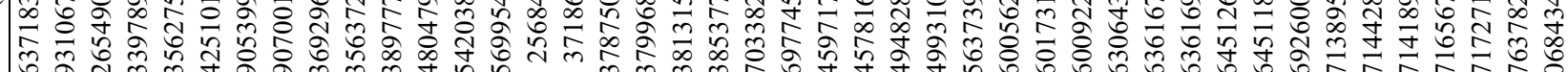

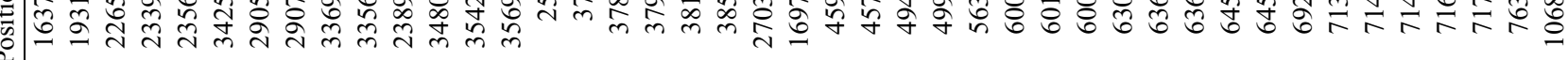

ป ป ป

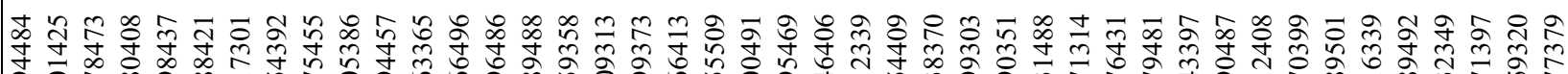

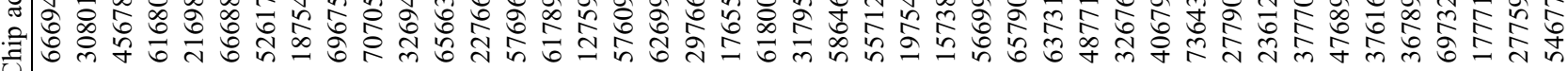

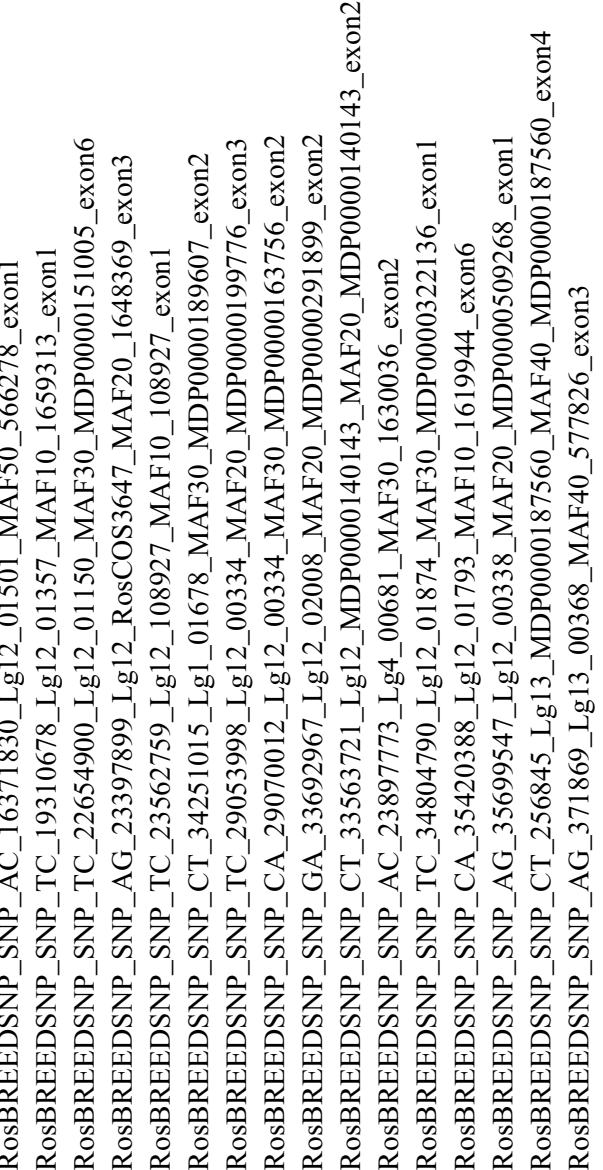

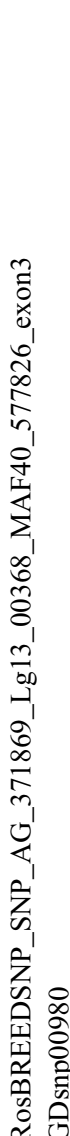

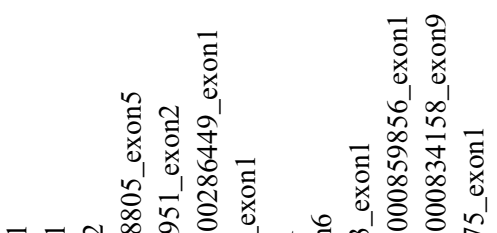

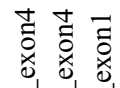

चี

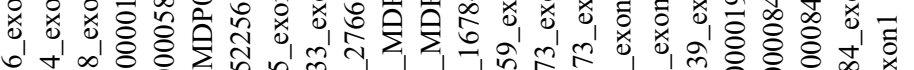

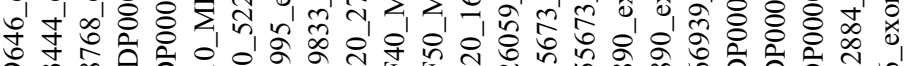
สิ

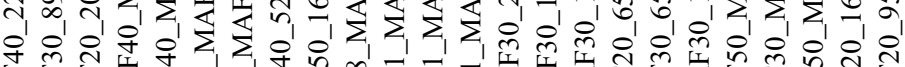

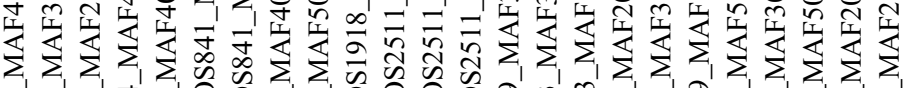

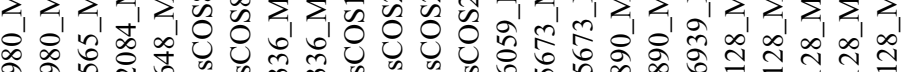

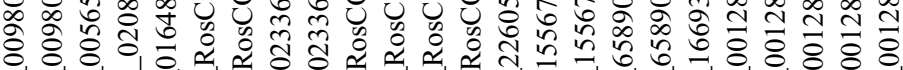

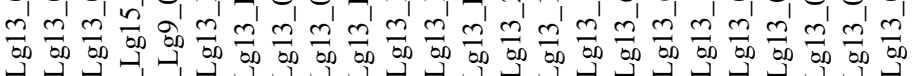
क人

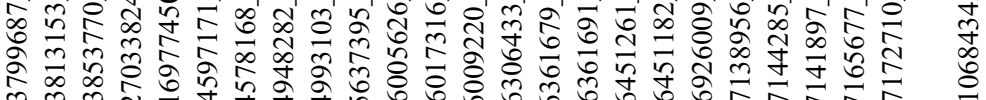

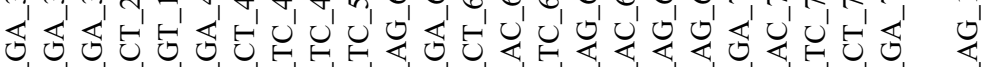

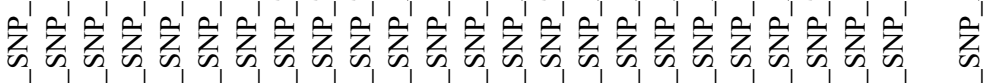




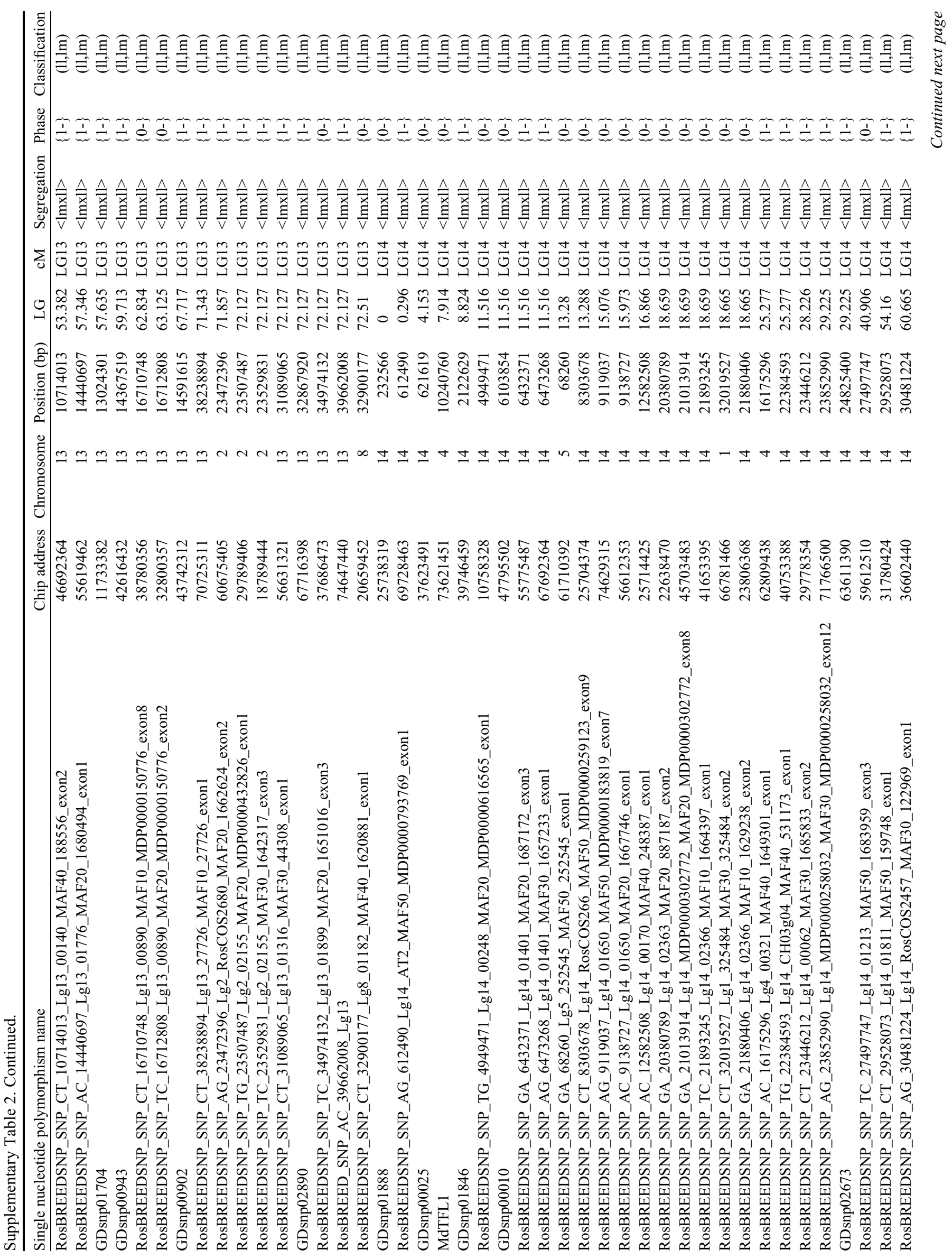




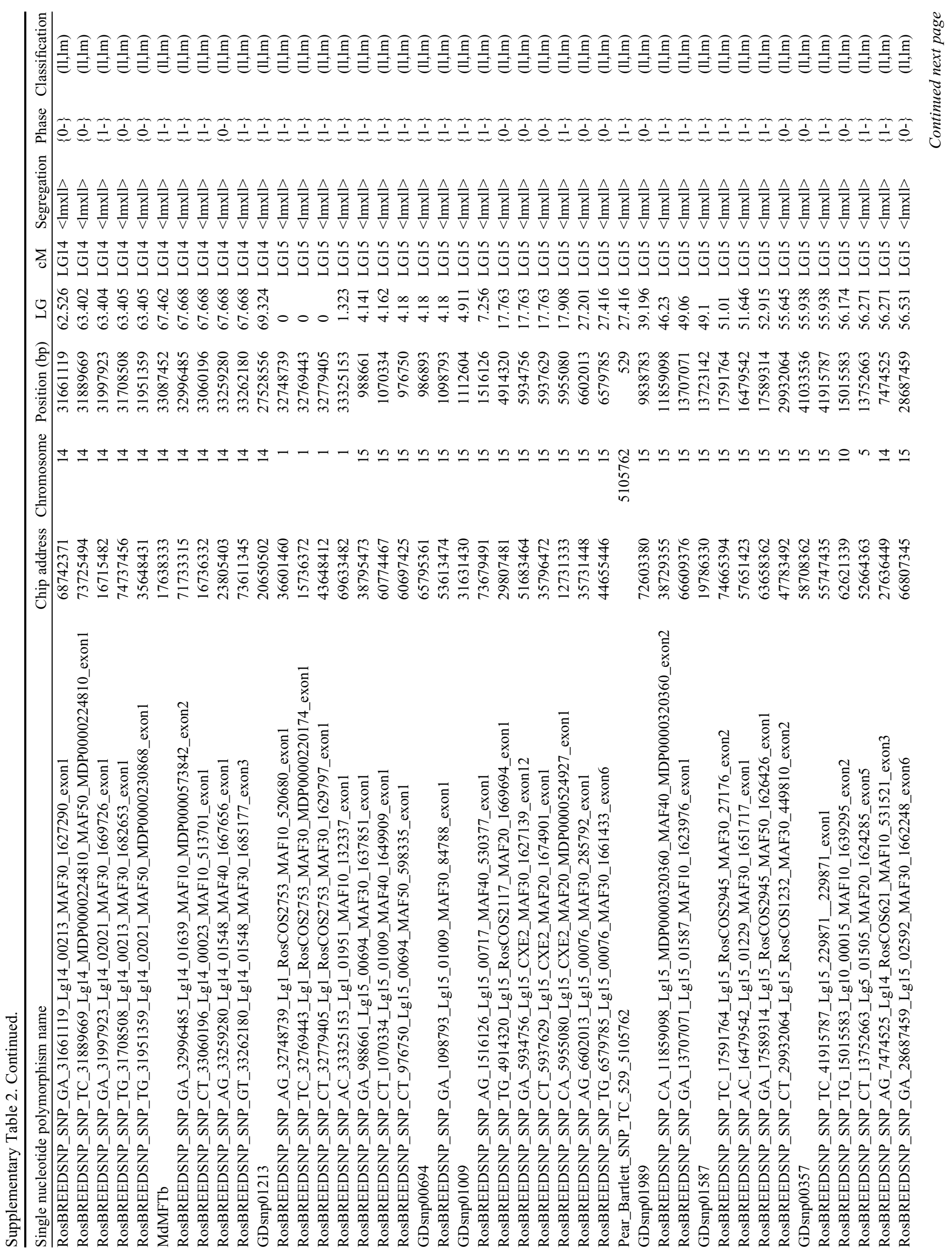




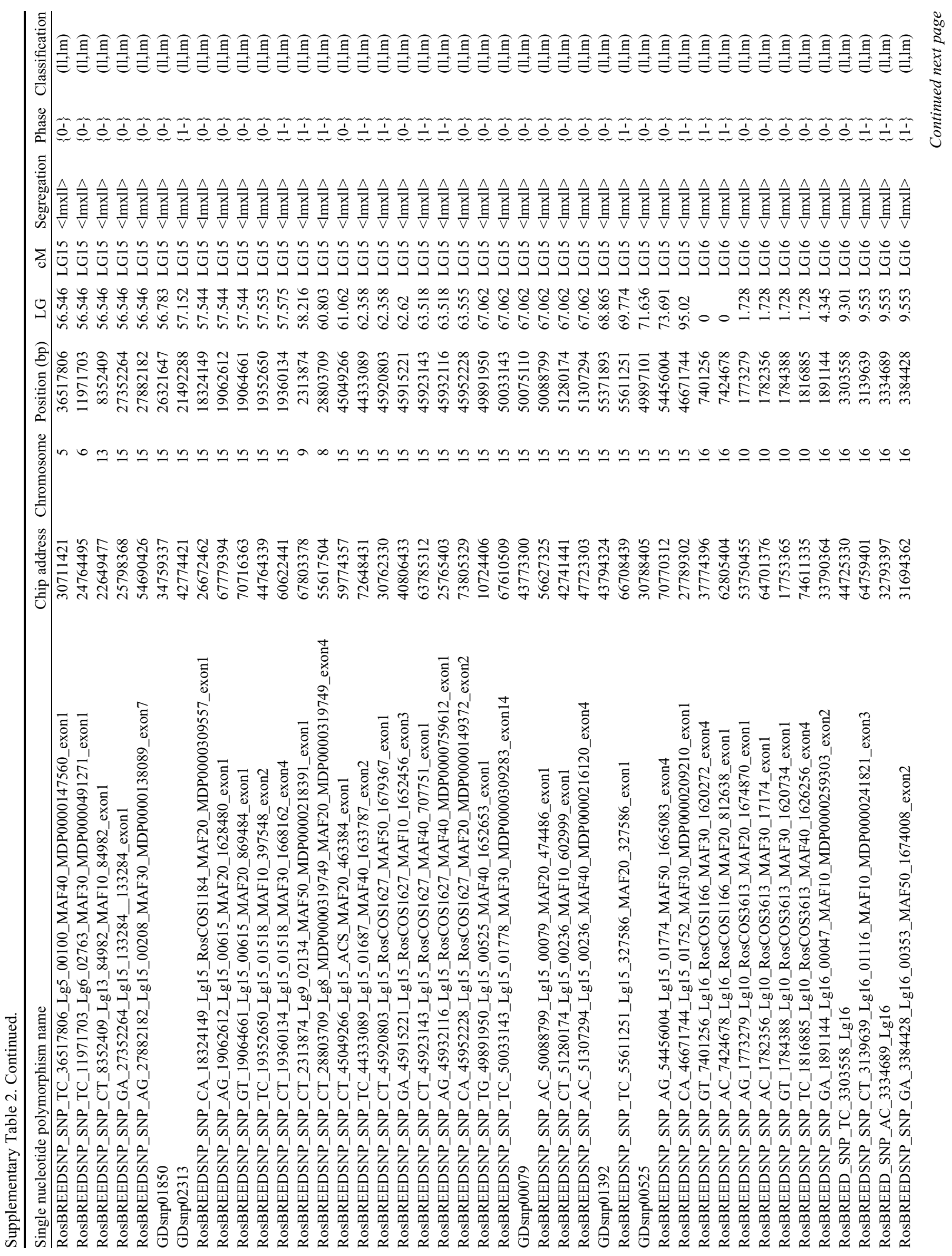




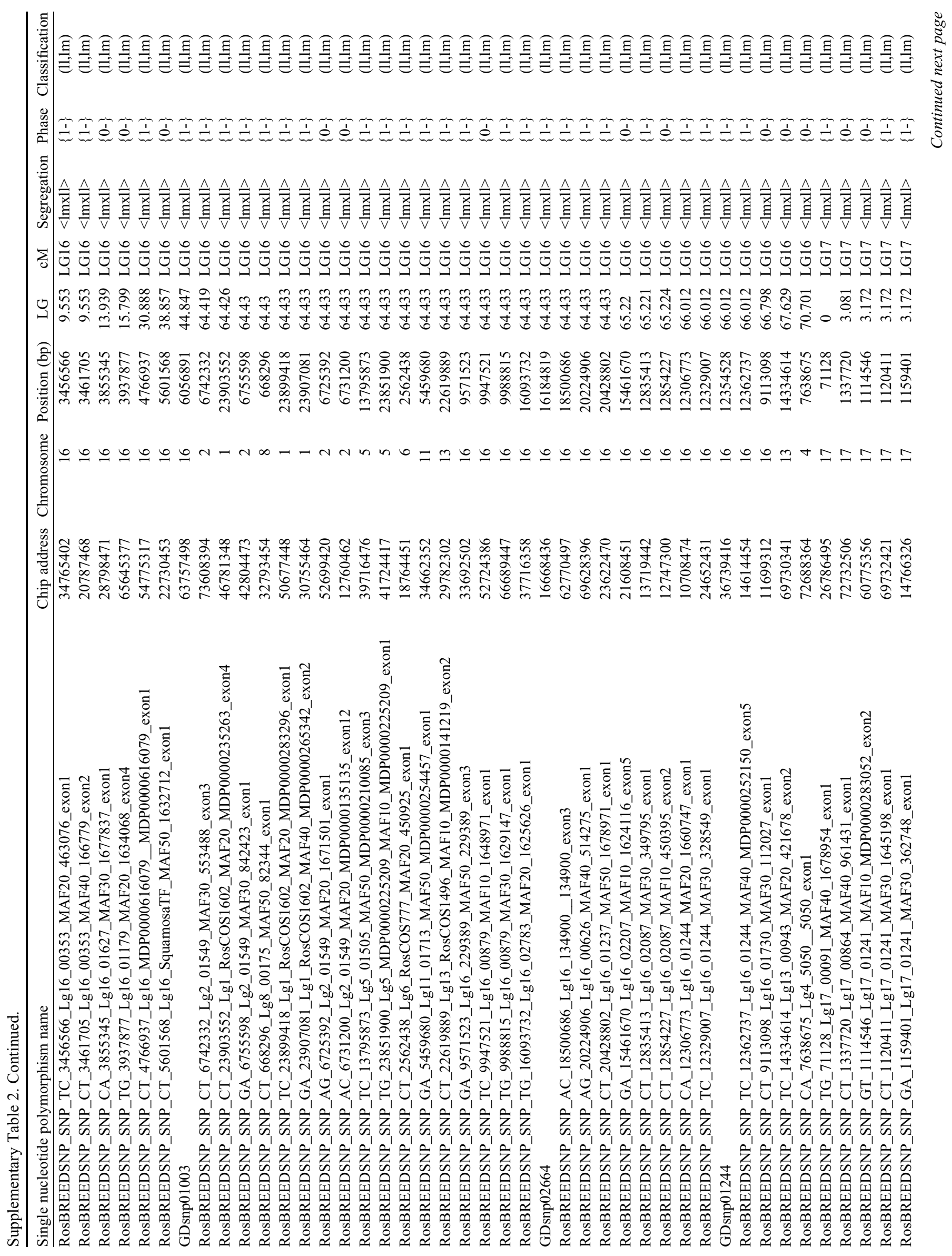




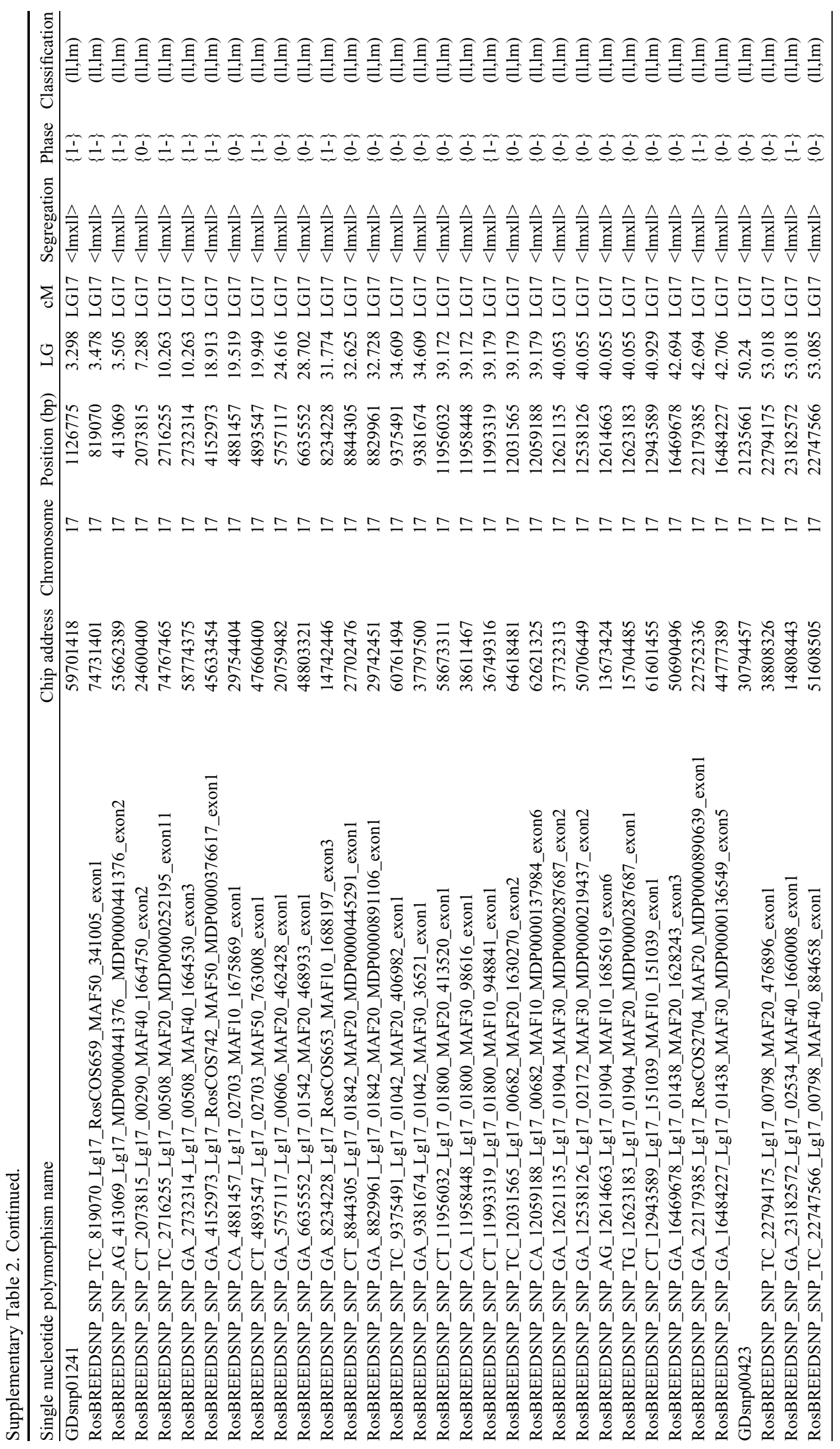




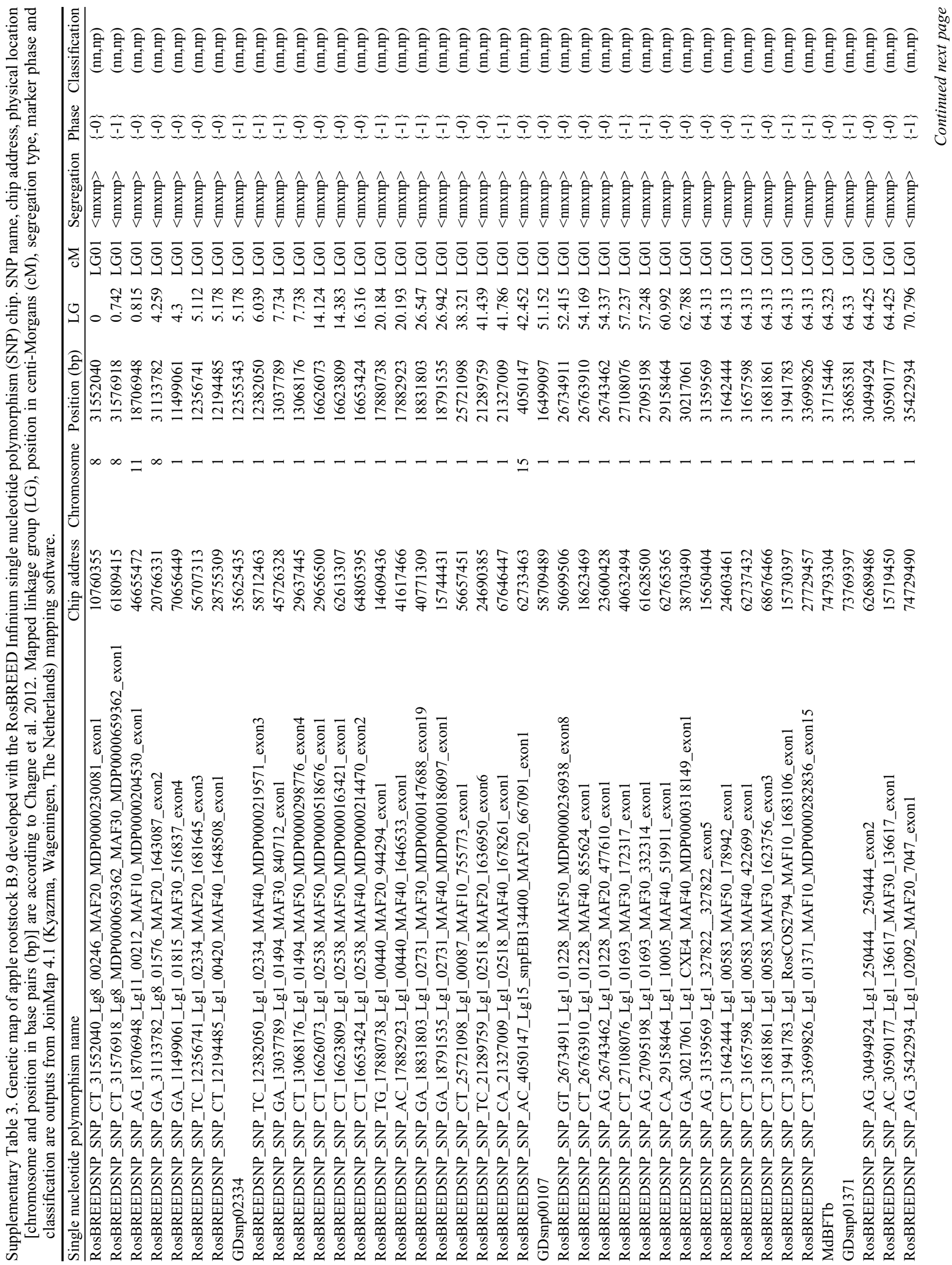




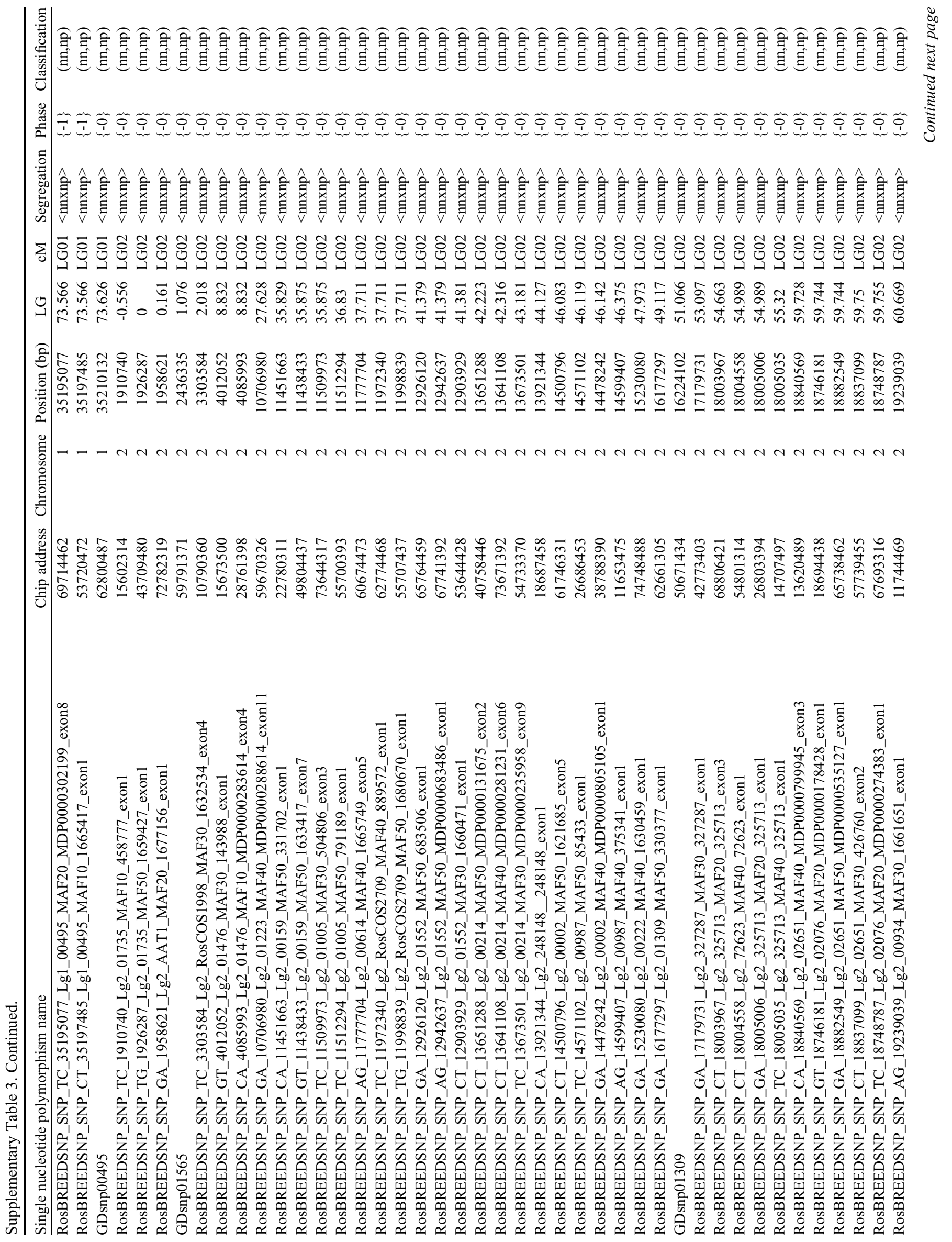




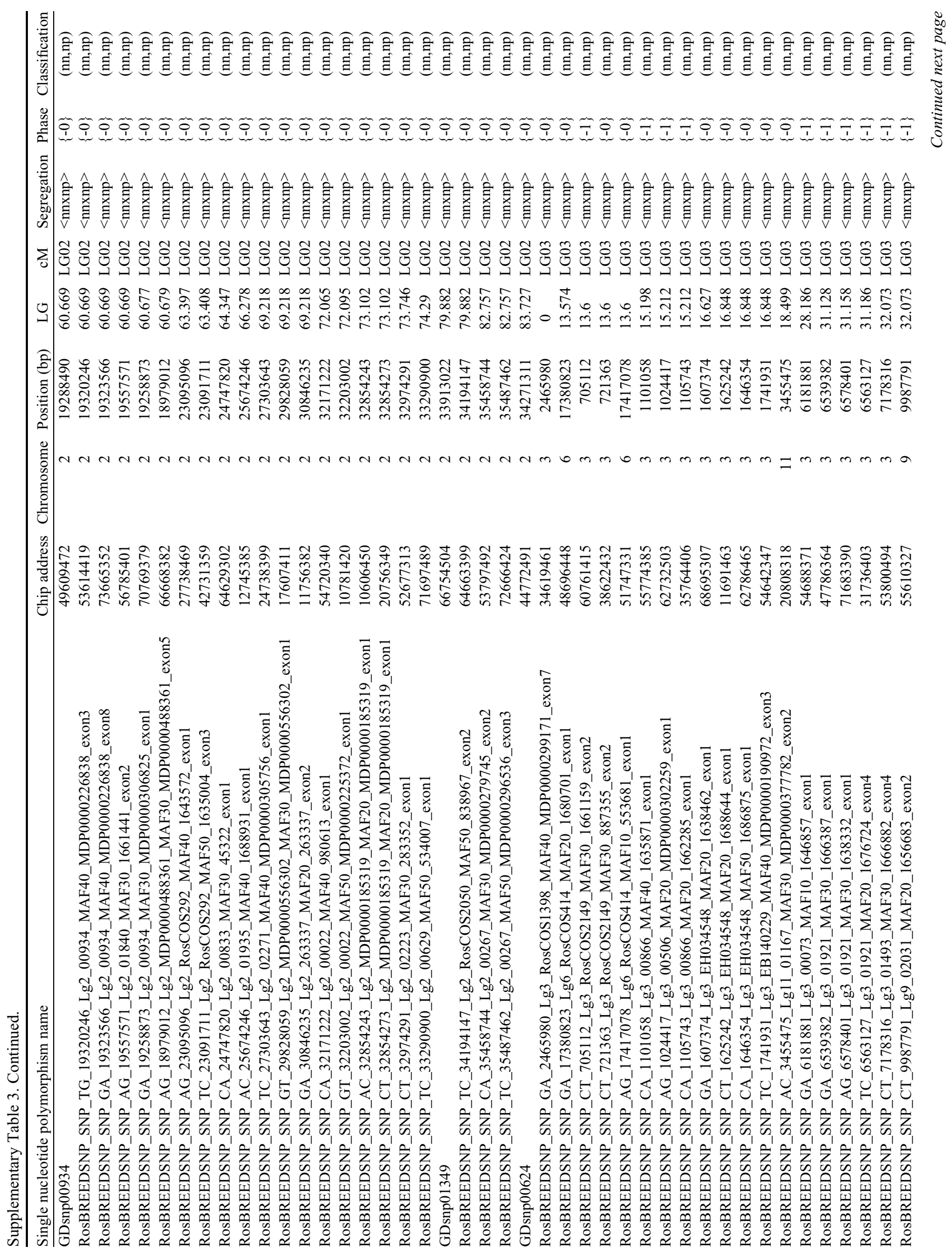




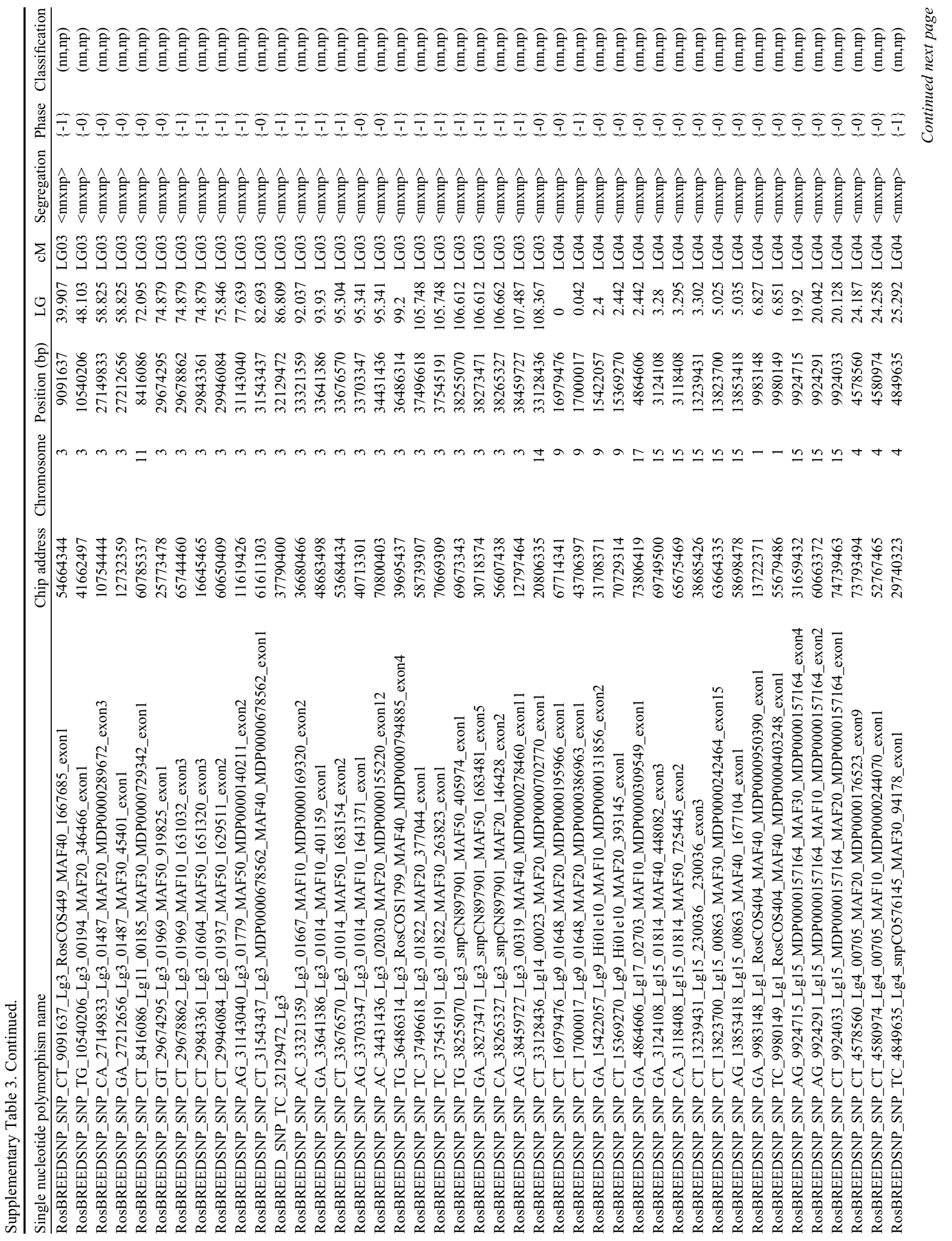




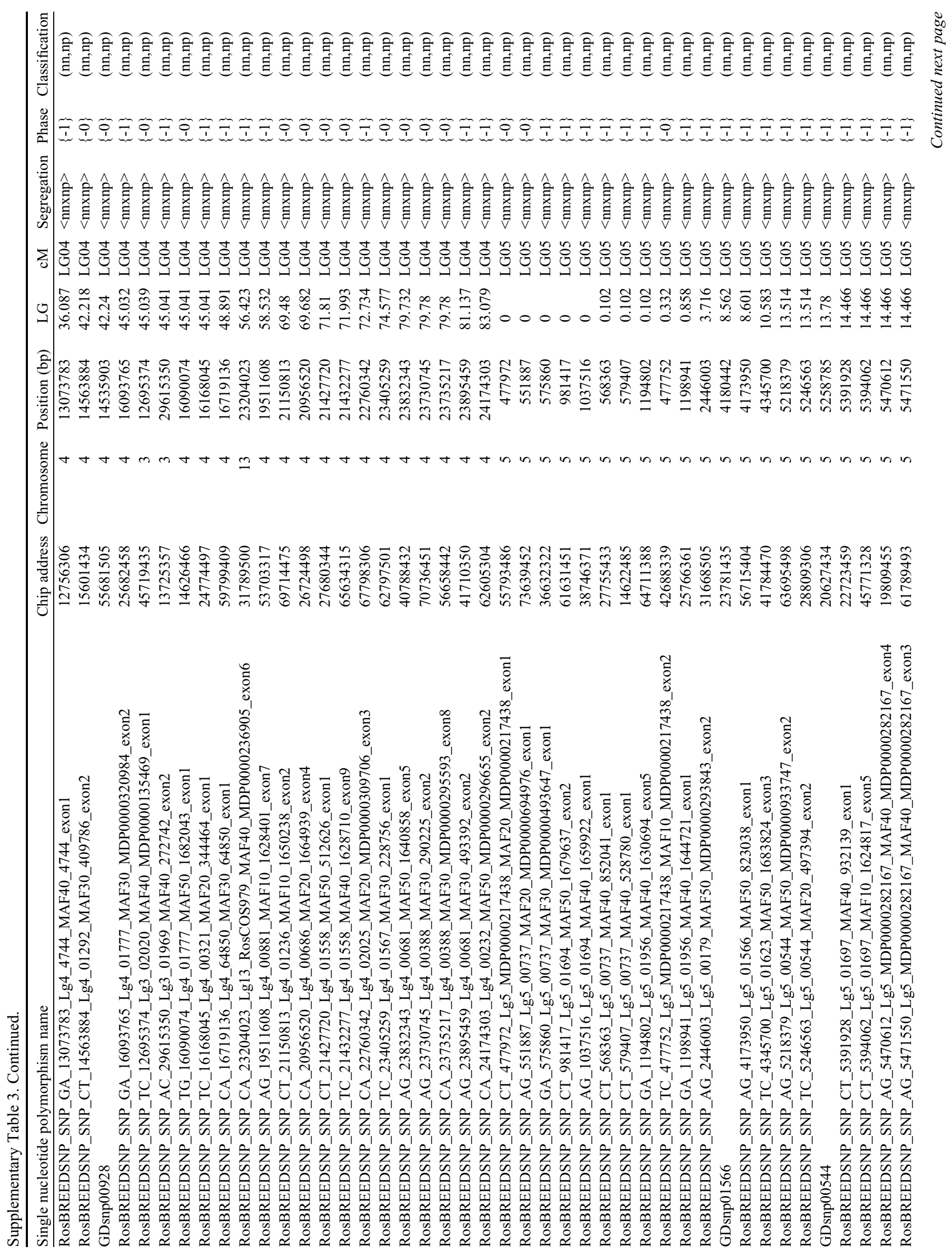




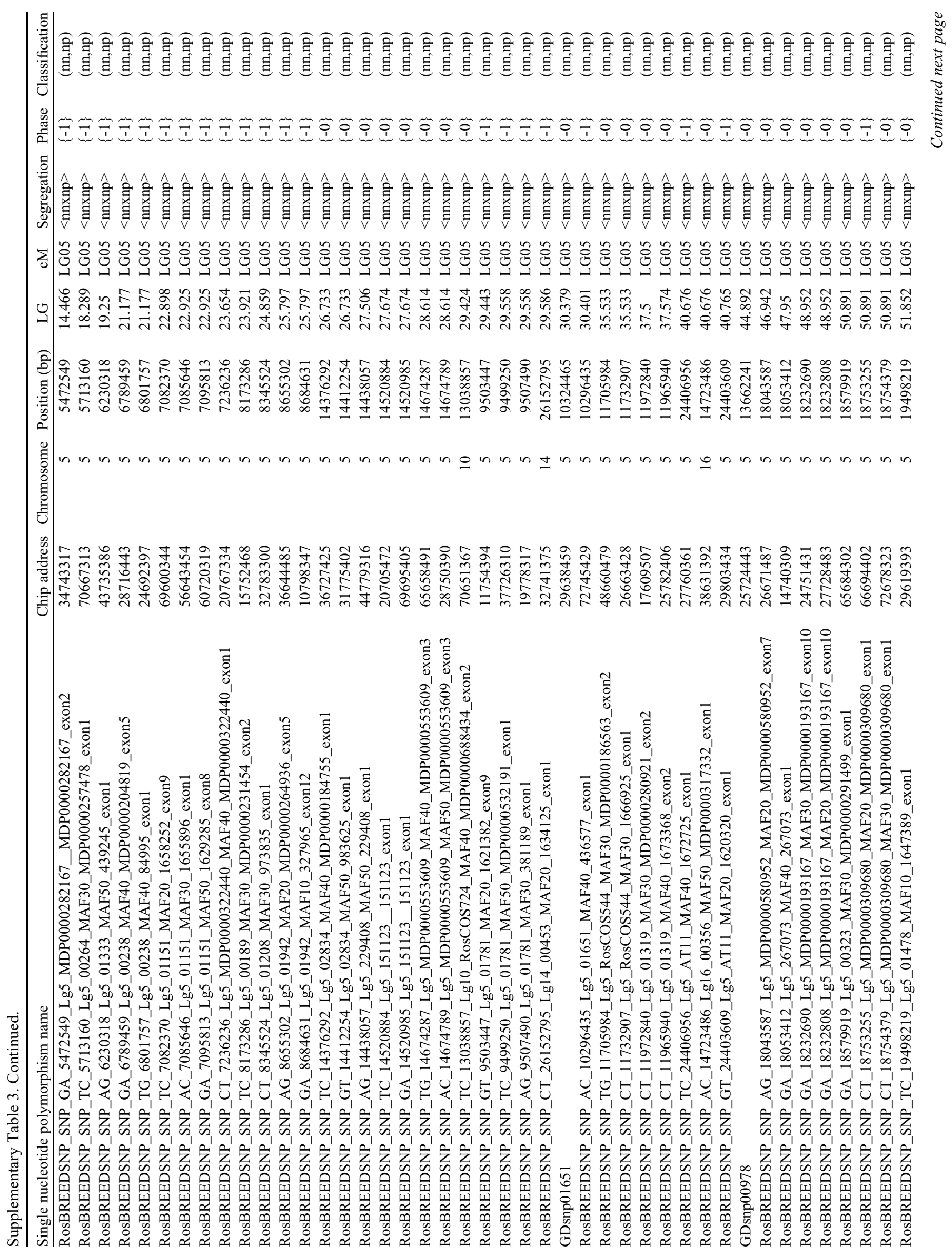




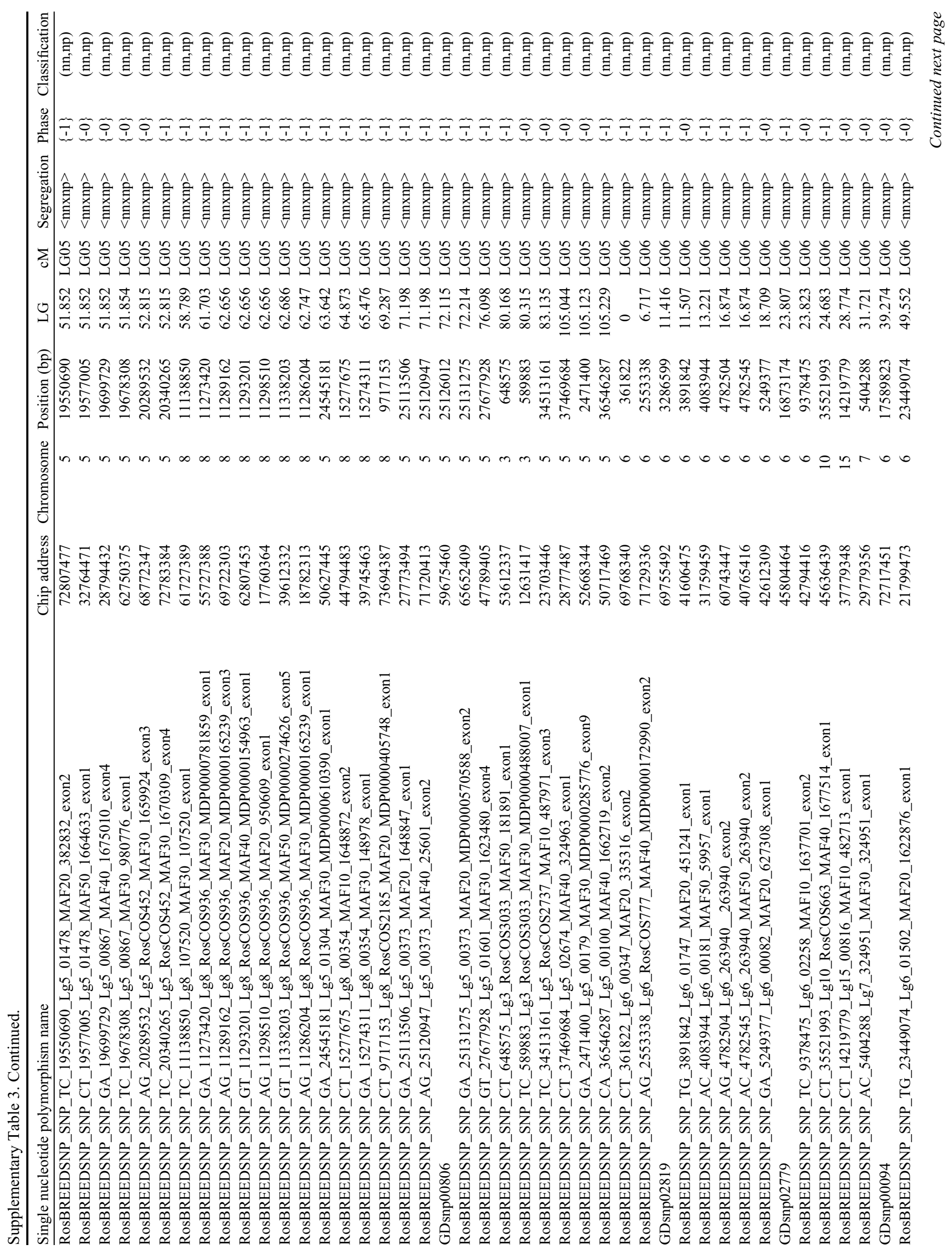




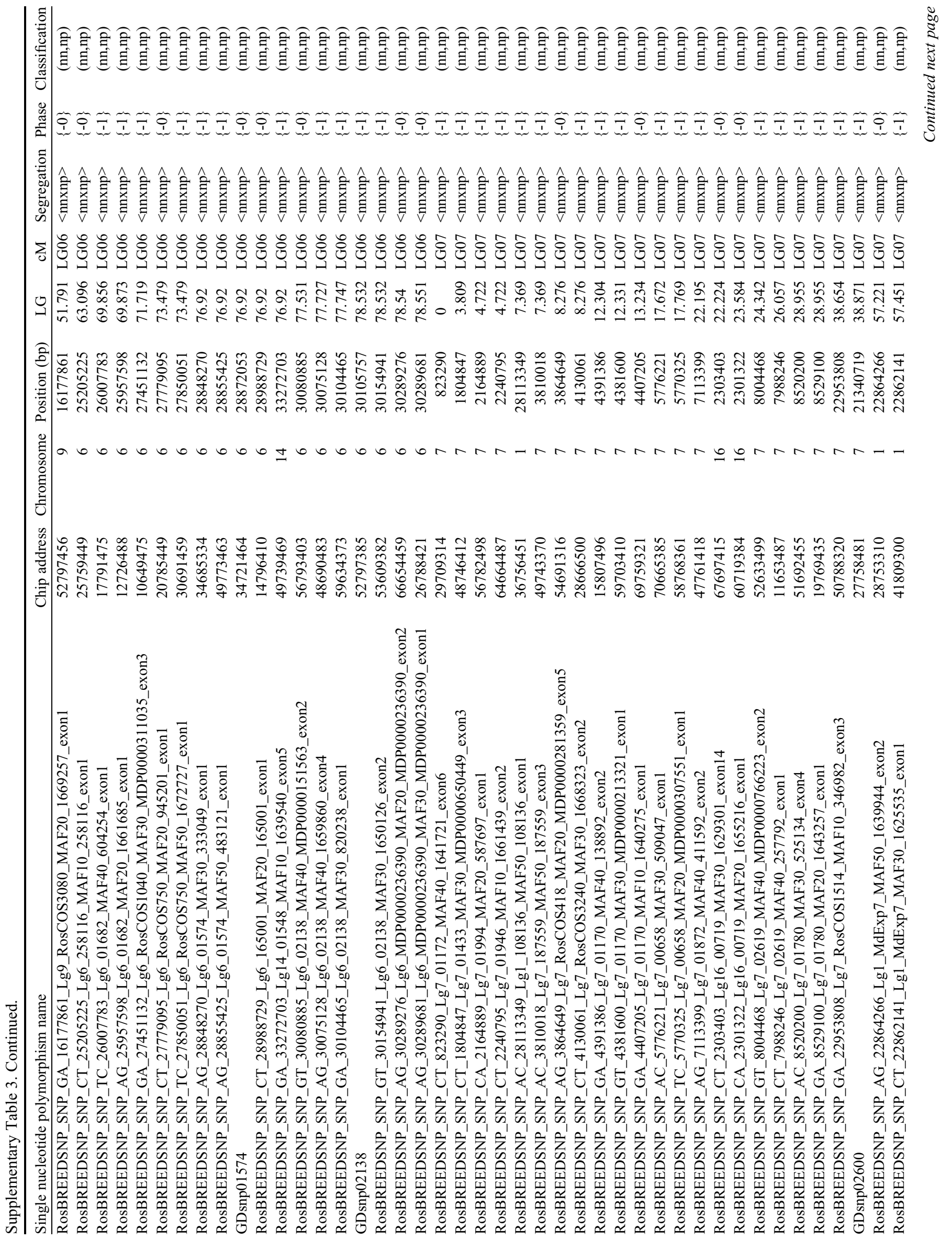




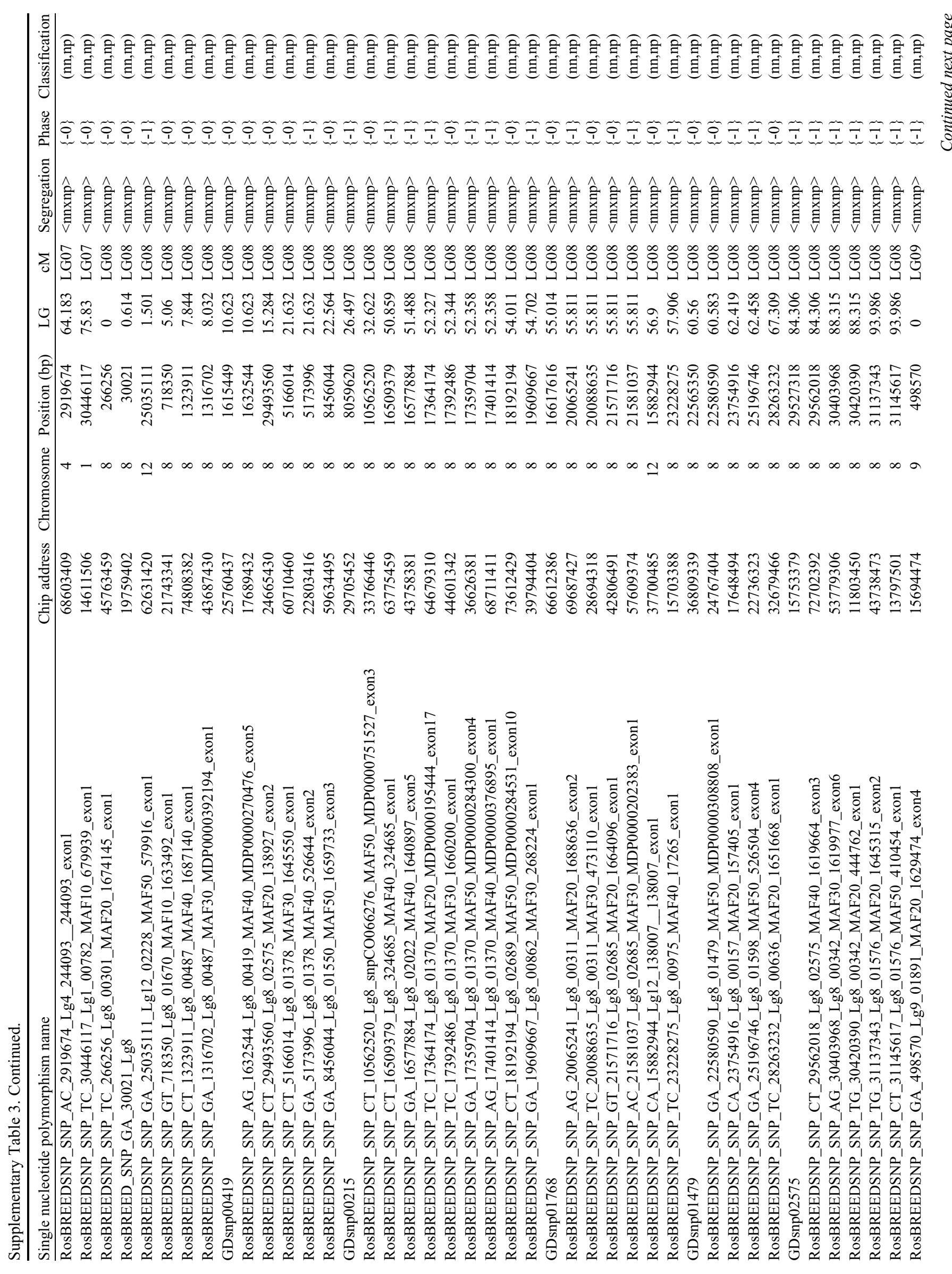




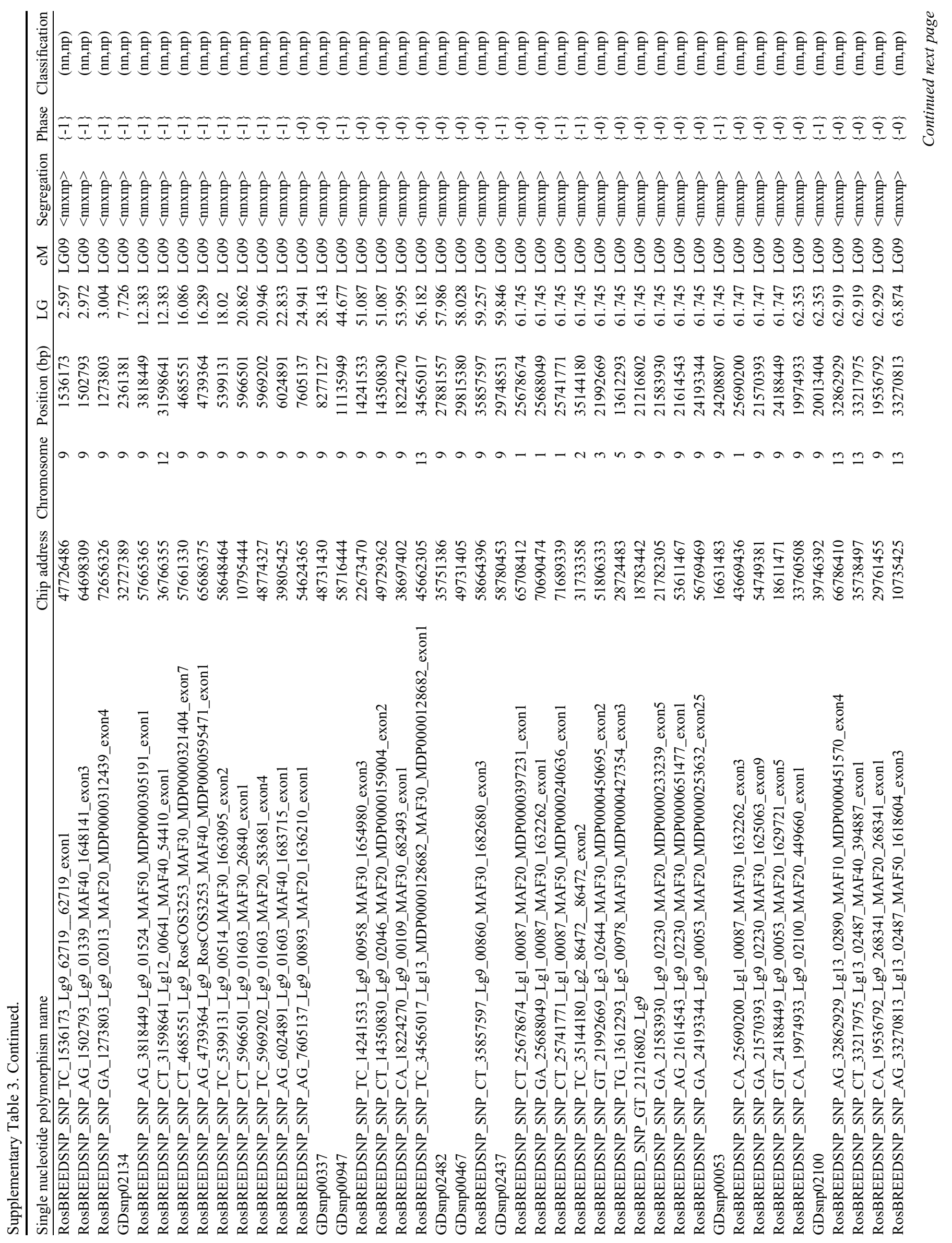




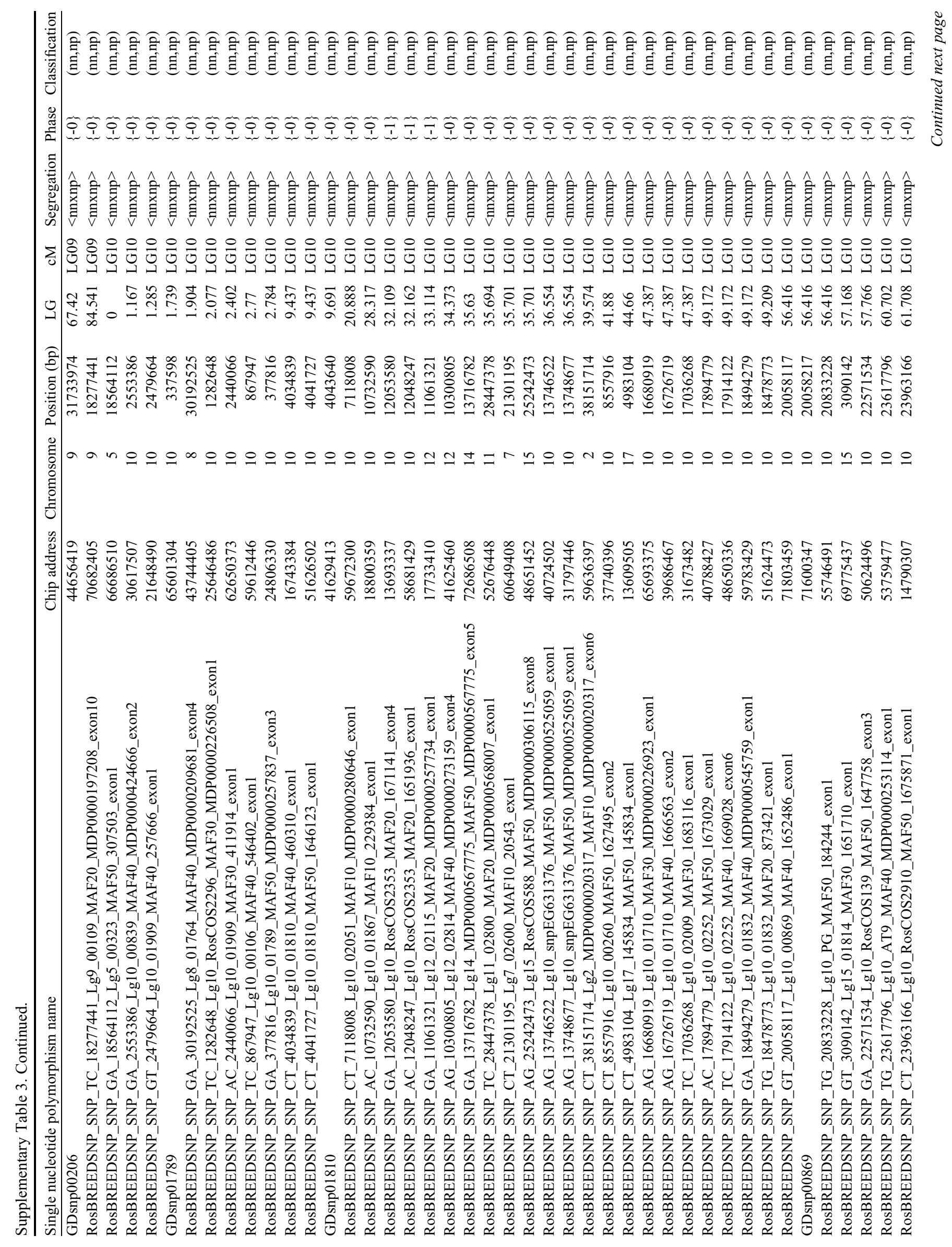




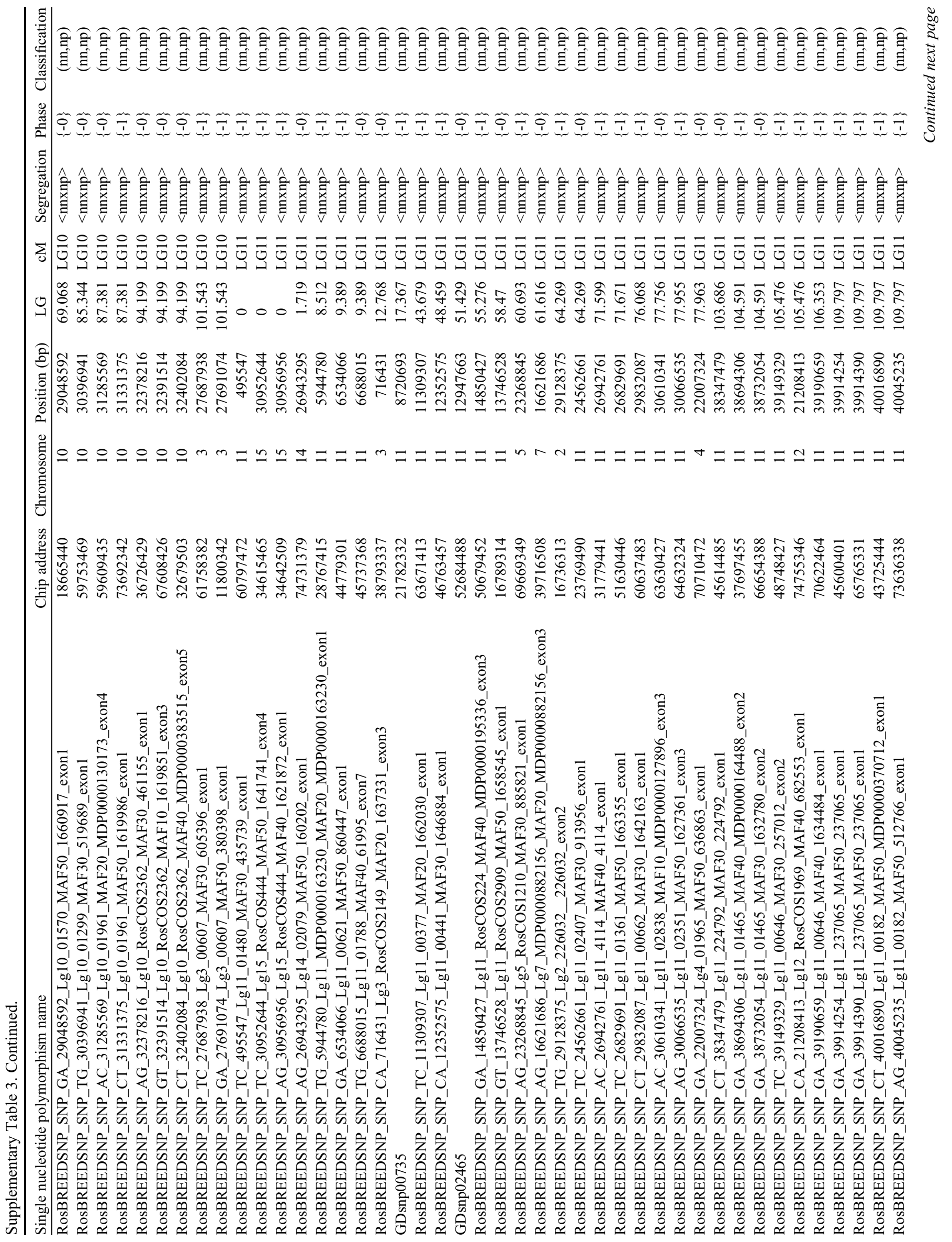




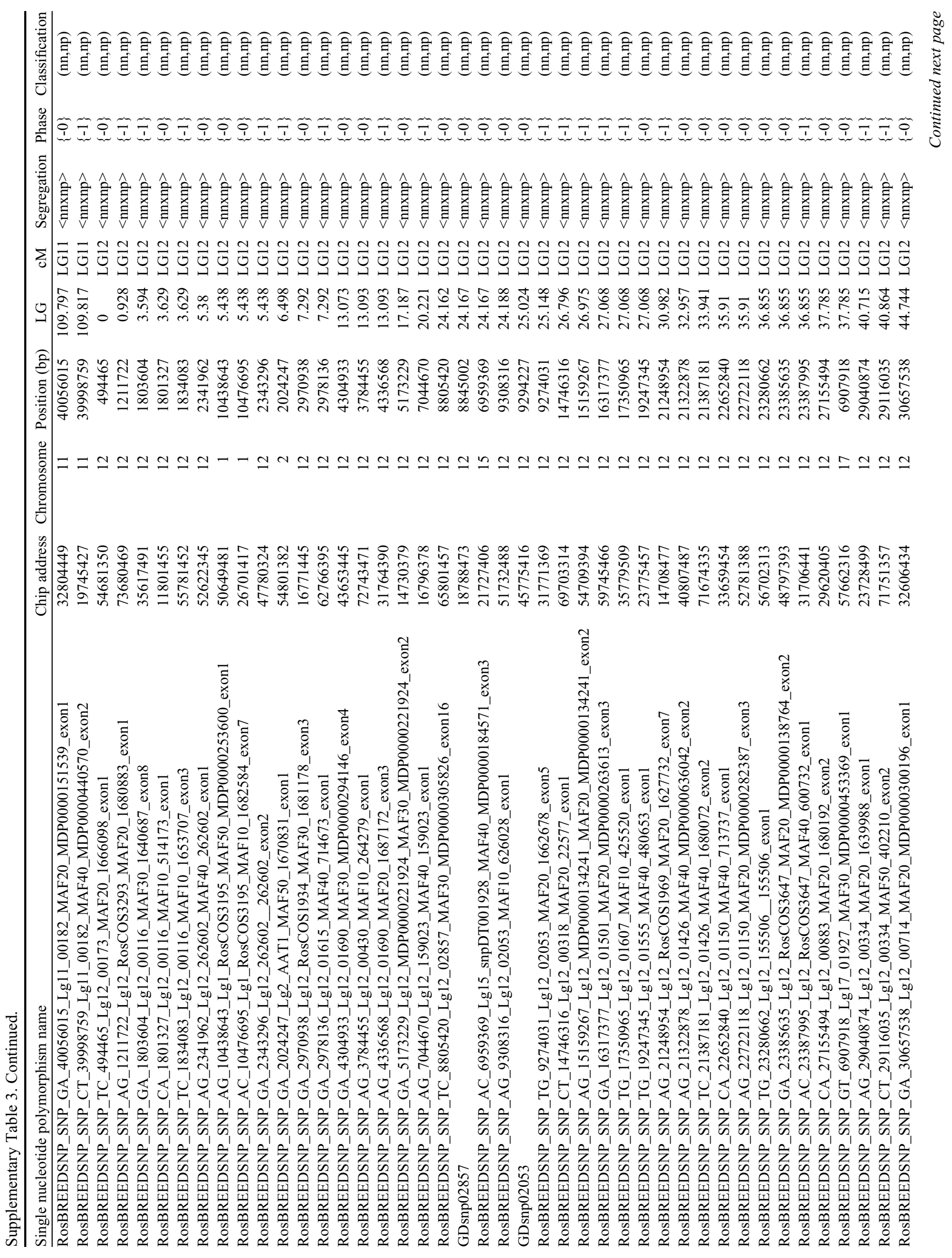




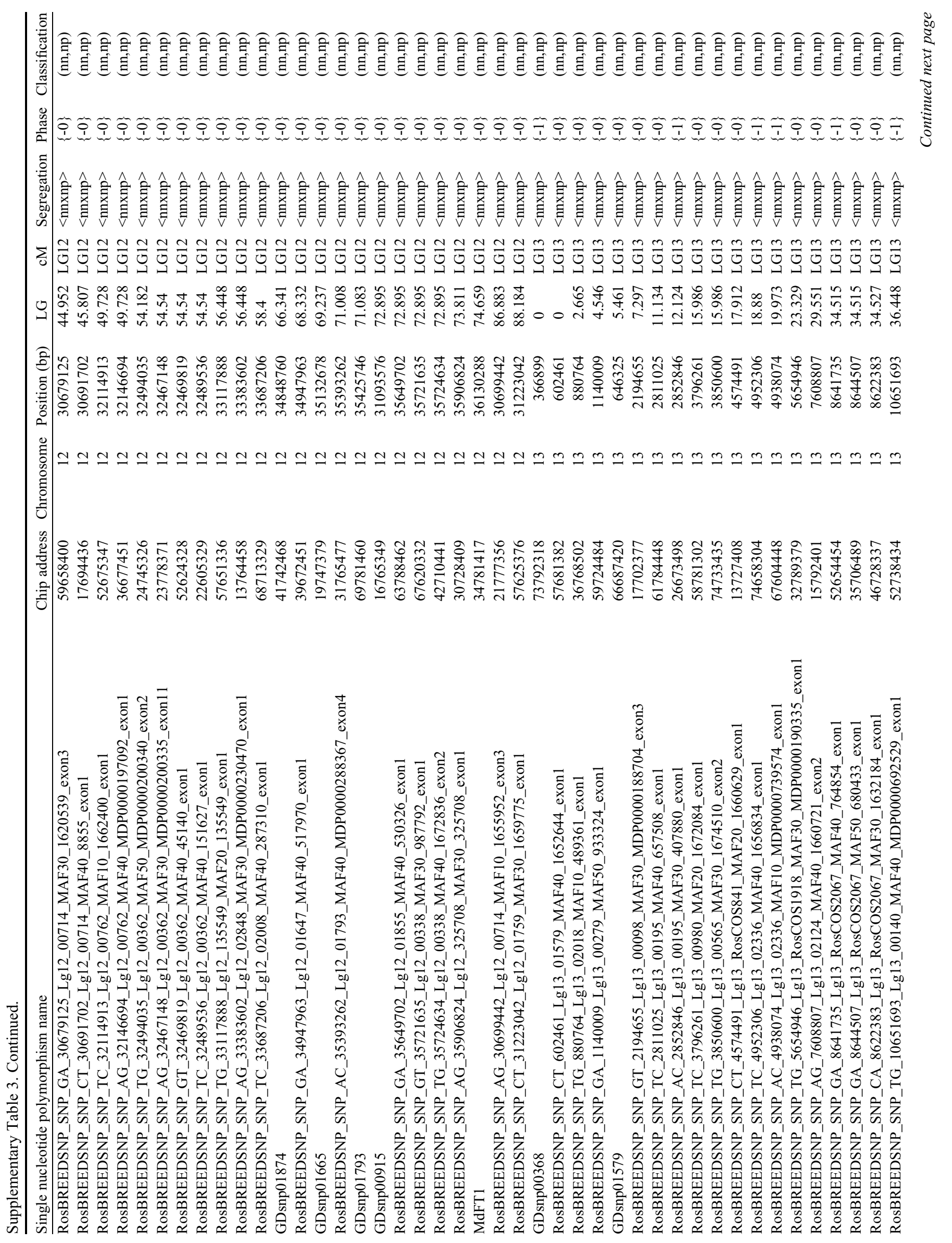




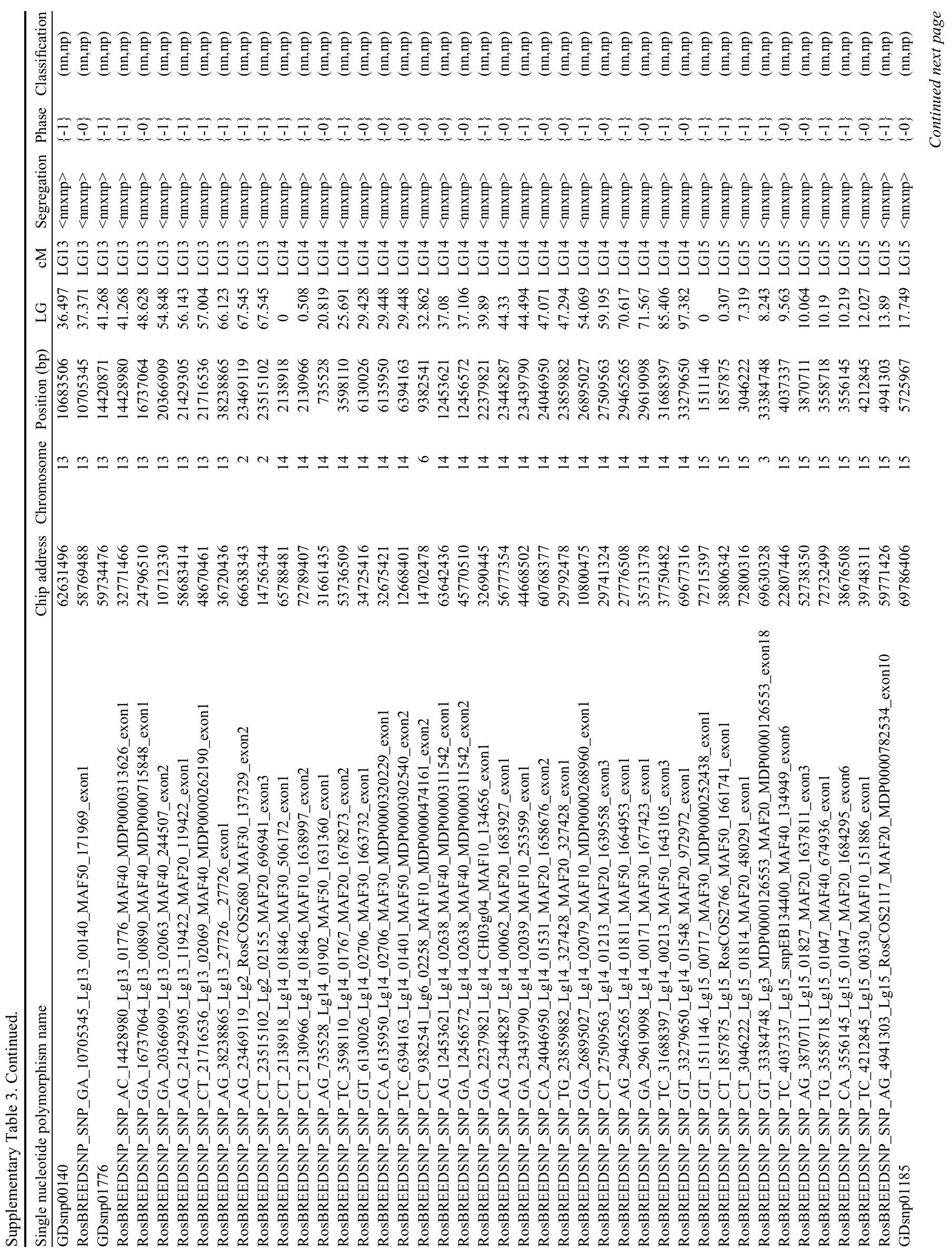




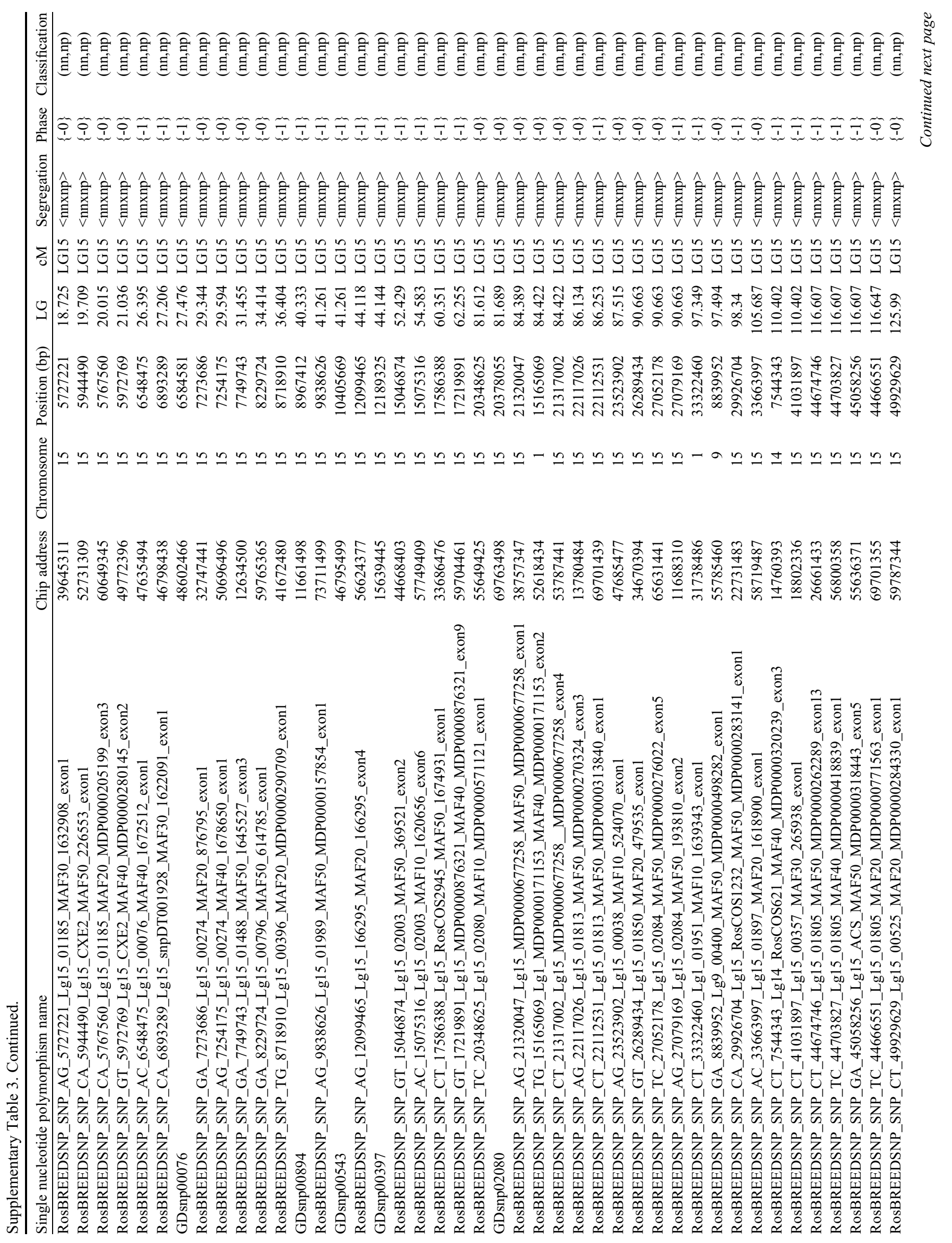




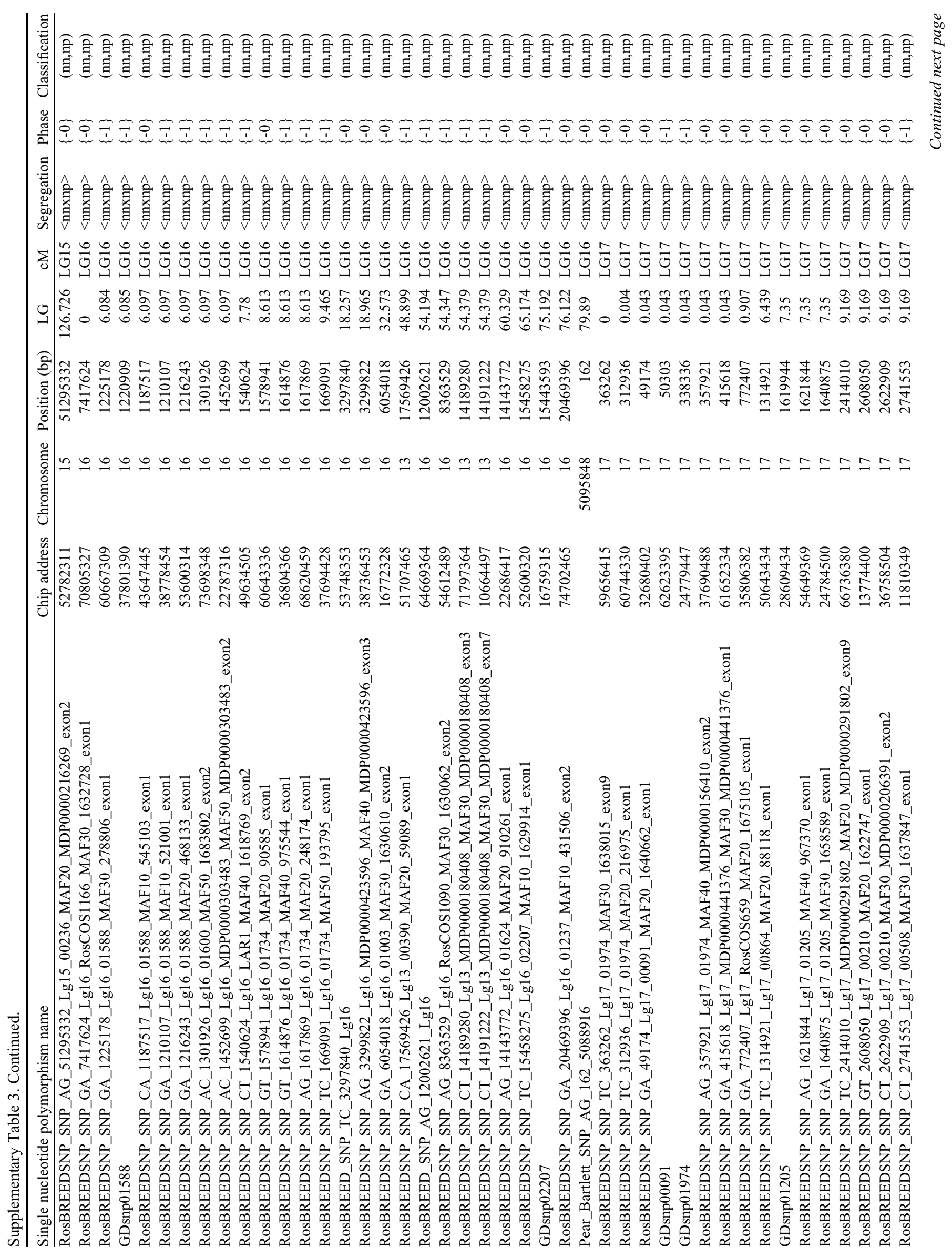




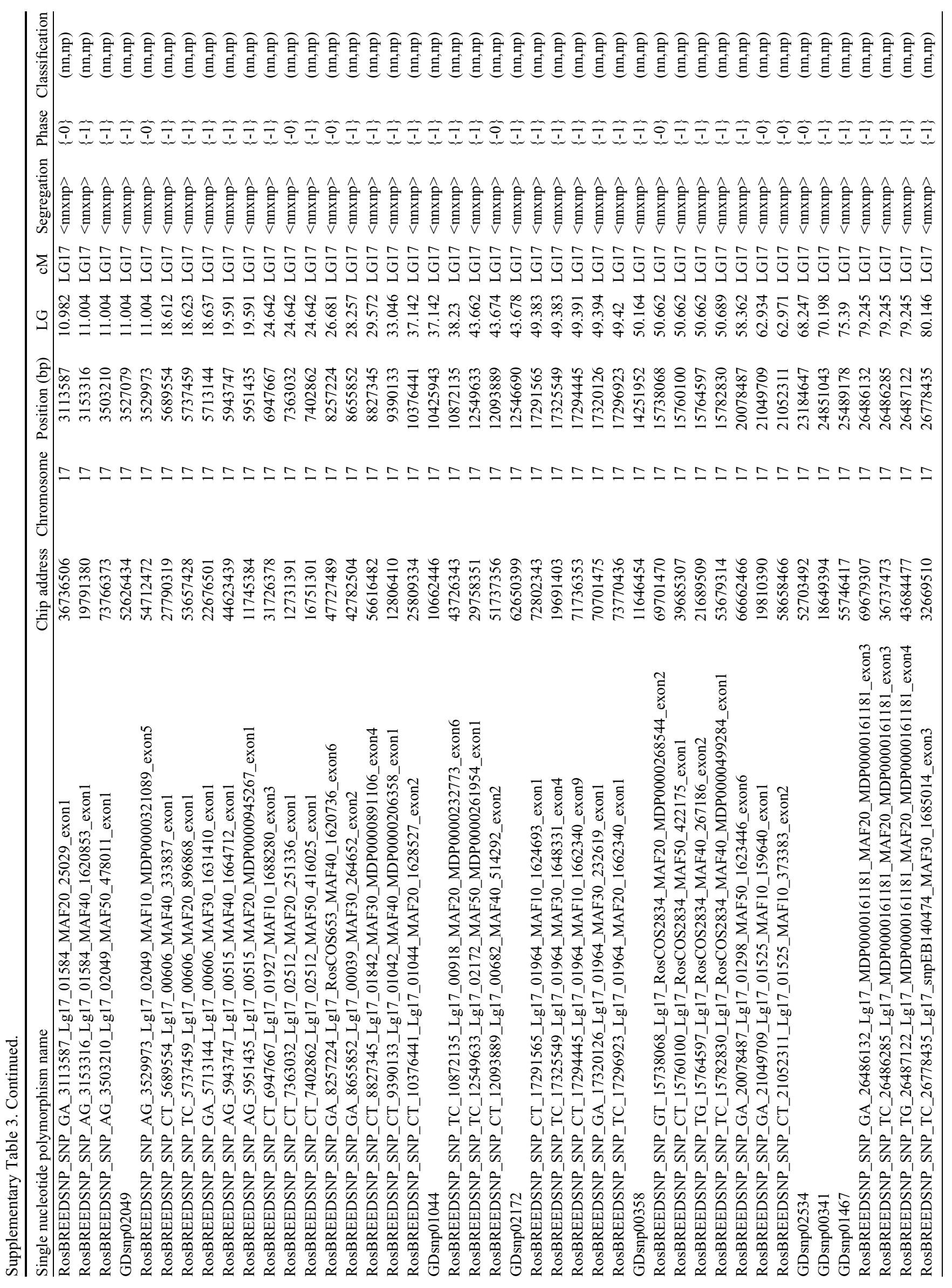

